ANTIQUITAS VIVA 


\section{UNIVERSITY OF LATVIA}

Faculty of Humanities

Chair of Classical Philology

Centre for Hellenic Studies

\section{ANTIQUITAS}

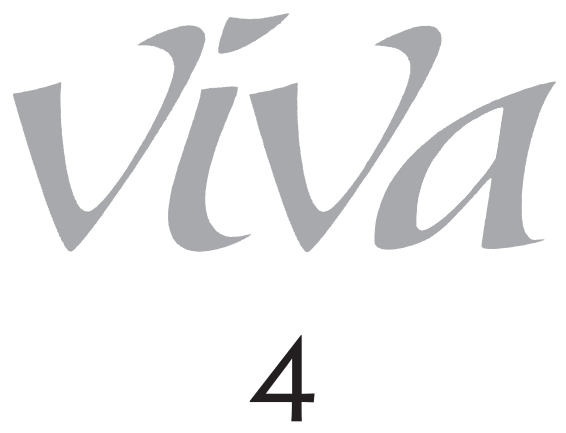

\section{studia classica}

Editors:

Brigita Kukjalko

Ojārs Lāms

Ilze Rūmniece

University of Latvia 


\section{LATVIJAS UNIVERSITĀTE}

Humanitāro zinātṇu fakultāte

Klasiskās filologijas katedra

Hellēnistikas centrs

ANTIQUITAS

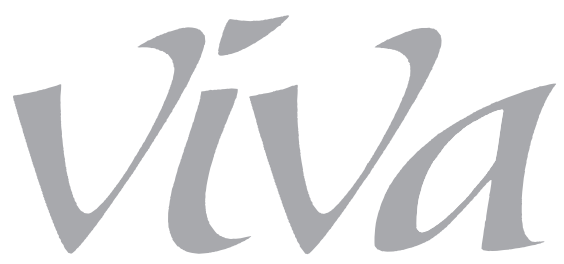

$$
4
$$

\section{studia classica}

Zinātniskie redaktori un sastādītāji:

Brigita Kukjalko

Ojārs Lāms

Ilze Rūmniece

LU Akadēmiskais apgāds 
UDK 821.14'02(063)

An 856

Izdevums tapis ar ERAF projekta "Atbalsts Latvijas Universitātes starptautiskās sadarbības projektiem un citiem starptautiskās sadarbības pasākumiem zinātnē un tehnologijās" Nr. 2010/0202/2DP/2.1.1.2.0/10/APIA/VIAA/013 atbalstu

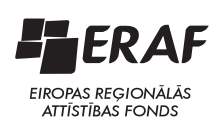

IEGULDİJUMS TAVĀ NĀKOTNE
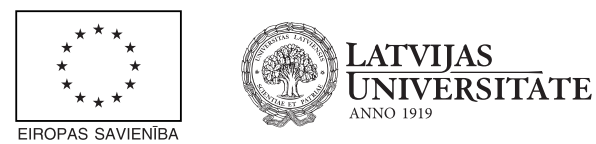

Rakstu krājums izdots ar Latvijas Universitātes Humanitāro zinātṇu fakultātes Domes 2013. gada 17. jūnija lēmumu, protokola Nr. 2251-V2-2/15.

$$
\begin{gathered}
\text { Redakcijas kolēgija: } \\
\text { NIJOLE JUHN̦EVIČIENE } \\
\text { (Viḷna, Viḷnas Universitāte) } \\
\text { ANDRA KALNAČA } \\
\text { (R̄̄ga, Latvijas Universitāte) } \\
\text { SERGEJS KARPJUKS } \\
\text { (Maskava, Krievijas Valsts humanitāro zinātnuu universitāte) } \\
\text { BRIGITA KUKJALKO } \\
\text { (Rīga, Latvijas Universitāte) } \\
\text { OJĀRS LĀMS } \\
\text { (Rīga, Latvijas Universitāte) } \\
\text { VITA PAPARINSKA } \\
\text { (Rīga, Latvijas Universitāte) } \\
\text { ILZE RŪMNIECE } \\
\text { (Rīga, Latvijas Universitāte) } \\
\text { HORĀCIJS VELLA } \\
\text { (Valeta, Maltas Universitāte) }
\end{gathered}
$$

Visi krājumā ievietotie zinātniskie raksti ir recenzēti.

Sengrieḳu valodas tekstu redaktors MĀRTIN̦Š LAIZĀNS Latviešu valodas tekstu literārā redaktore GITA BĒRZIṆA

Angḷu valodas tekstu tulkotāja RASMA MOZERE Anglu valodas tekstu redaktors NORMUNDS TIT ĀNS

Mākslinieks ANDRIS NIKOLAJEVS Maketētāja ANDRA LIEPIṆA 


\section{SATURS / CONTENTS}

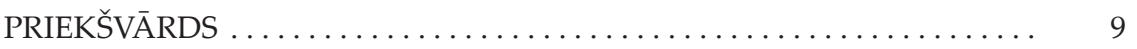

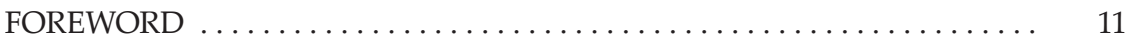

$\Pi \mathrm{AI} \Delta \mathrm{EIA}$

\section{Vita Paparinska}

PRAGMATISMS IZGLĪTĪBĀ - MŪSDIENU NOVITĀTE VAI ANTĪKĀS

PASAULES MANTOJUMS?

Pragmatism in Education - Modern Novelty or Legacy

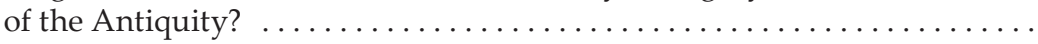

\section{Harijs Tumans}

HELLĒṆU DISKUSIJAS PAR PAIDEIJU

The Hellenic Discussion About Paideia

\section{Gita Bērziņa}

SIMPOSIJS KĀ IZGLITTOŠANĀS INSTITŪCIJA SENAJĀ GRIEĶIJĀ

Symposium as an Institution of Education in Ancient Greece .........

\section{Maria Giannaki}

DOCTA PUELLA IN THE ELEGIES OF PROPERTIUS: THE REFLECTION OF THE EDUCATION SYSTEM IN ROME IN THE TIME OF AUGUSTUS Docta Puella Propertija elēgijās: izglītības sistēmas atspoguḷjums

\section{Līva Muižniece}

THE MEANING OF TO GENOS TOU EIDOUS MEROS AND

TO EIDOS TOU GENOUS MEROS IN ARISTOTLE'S METAPHYSICS $\triangle 25$

To genos tou eidous meros un to eidos tou genous meros nozīme Aristoteḷa

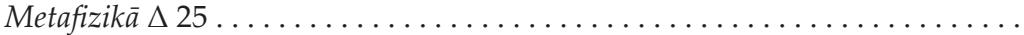

\section{Liva Bodniece}

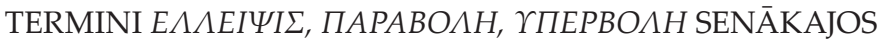
RĒTORIKAI UN ĢEOMETRIJAI VELTĪTAJOS TEKSTOS

The Terms " $E \lambda \lambda \varepsilon \iota \psi \iota \varsigma, \Pi \alpha \rho \alpha \beta \sigma \lambda \eta \eta^{\prime}, \Upsilon \pi \varepsilon \rho \beta \sigma \lambda \eta$ in the Oldest Texts

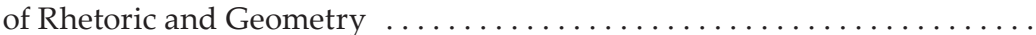




\section{Ilona Gorneveva}

LIETDERİGĀKAIS RUNAS VEIDS: MENANDRA RĒTORA

TRAKTĀTU LIECİBAS

The Most Applicable Kind of Speech: Testimonia of Treatises

by Menander Rhetor ...................................

\section{Igors Konins}

TËLA VEIDOŠANA ANTİKAJĀ RĒTORIKĀ UN

PSEIDOVĒSTURISKĀS VĒSTULES

Image Building in Ancient Rhetoric and Pseudo-Historical Letters .......

\section{Ieva Fībiga}

METAFORAS KOGNITĪVĀ FUNKCIJA

(Galēna traktāts Par ēdienu spēju)

The Cognitive Function of Metaphor

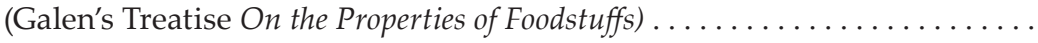

\section{Georgios Theotokis}

FROM ANCIENT GREECE TO BYZANTIUM: STRATEGIC

INNOVATION OR CONTINUITY OF MILITARY THINKING?

No Senās Grieḳijas uz Bizantijas pasauli: stratēgiisks jauninājums

vai militāro zināšanu pēctecība? ............................

\section{Ojārs Lāms}

IZGLĪTOTS PSMAIO (ROMEJS JEB BIZANTIETIS) UN ANTĪKĀ

LITERATŪRA. Atsevišķa gadījuma izpēte: Leona Diakona teksti

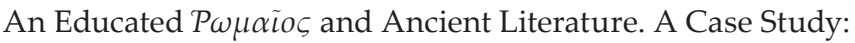

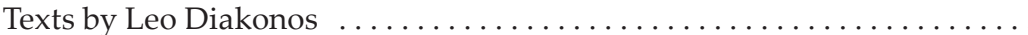

\section{Brigita Cīrule}

AUGUSTİNS EICĒDIJS UN VIN̦A POĒMA DAUGAVAS PAKLĀJS:

PAIDEIA DISKURSS

Augustinus Eucedius and His Poem

The Daugava Carpet: Paideia Discourse

\section{Dace Strelēvica-Ošiņa}

CUSTOS SERMONIS (VALODAS SARGS): İSS IESKATS

IZPRATNĒ PAR DZIMTĀS VALODAS MĀCĪŠANU LATĪṆU UN

LATVIEŠU TRADİCIJĀ

Custos Sermonis (Guardian of Language): An Insight into the Perception of Native Language Instruction in Latin and Latvian Traditions ........ 


\section{A N N Ā L E S}

I VARIA

Gita Bērziņa, Līva Bodniece

KLASISKĀS FILOLOG̣IJAS STUDIJU PROGRAMMAS

LU 21. GADSIMTA OTRAJĀ DESMITGADE

Vita Paparinska

COLLOQUIA BALTICA (2010-2012)

Mārtiṇš Laizāns

VOLATUS ACADEMICUS - AVES VILNIENSES

\section{Ojārs Lāms}

$P \bar{A} R$ KALNIEM AIZDIPA KA STIRNAS -

HELLĒNISTIKAS CENTRA 10 GADI

\section{Brigita Kukjalko}

PLATONA AKADĒMIJA: CEL̦ĀA UZ ZINĀ $\bar{S} A N \bar{A} M \ldots \ldots \ldots \ldots \ldots \ldots$

Ilze Rūmniece

DIALOGI ATGRIEŽAS ATĒNĀS

Iveta Skrastina

MARATONAI - 2500. SKRIENU, SKRIENU VEEL...

Brigita Cīrule

ROMAI - 2765

II RECENZIJAS

Dens Dimiņš

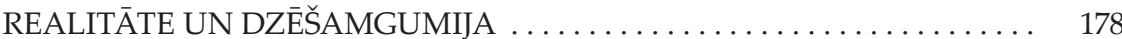

Mārtiṇš Laizāns

RİGAS HELLĒNIADE JEB AKADĒMISKAIS OLIMPISMS

III AIZSTĀVĒTIE PROMOCIJAS DARBI

BRIGITAS KUKJALKO PROMOCIJAS DARBS

SENGRIEKU FILOLOGIISKO TEKSTU VALODA.

FRAGMENTI NO PRÓFESORA OJĀRA BUŠA RECENZIJAS 
GITAS BĒRZIṆAS PROMOCIJAS DARBS

DIALOGA ŽANRA TEKSTI SENGRIEKYU PROZĀ:

LINGVOSTILISTISKAIS ASPEKTS.

FRAGMENTI NO PROFESORA OJĀRA LĀMA RECENZIJAS . . . . . . . . .

STUDIJU PAMATS RĪGĀ, DOKTORA GRĀDS ZVIEDRIJĀ:

SANITAS BALODES PROMOCIJAS DARBS VERBS OF MOTION

WITH DIRECTIONAL PREPOSITIONS AND PREFIXES IN

XENOPHON'S "ANABASIS" (Kustības verbi ar virziena prievārdiem

un priedēkliem Ksenofonta "Anabāzē").

SPEECH OF THE OPPONENT - PROFESSOR ILZE RŪMNIECE

(Oponentes profesores Ilzes Rūmnieces runa angḷu valodā)

IN MEMORIAM

Ināra Kemere (23.04.1939. - 04.09.2013.) . . . . . . . . . . . . . . . . . 200

Brigita Cīrule, Gita Bērziña

[Pieminas vārdi] .................................. 201

Ināru Kemeri atceroties

Dens Dimiṇš, Māra Grudule, Ojārs Lāms, Ilze Rūmniece ........... 203

ABSOLVENTI LATVIJAS UNIVERSITĀTES

KLASISKĀS FILOLOG̣IJAS STUDIJU PROGRAMMĀS (2009-2012)

Alumni in Classical Philology Study Programmes

at the University of Latvia (2009-2012) . . . . . . . . . . . . . . . . . . . . . . 207

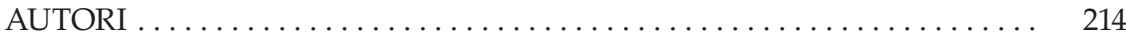

CONTRIBUTORS ................................... 215 


\section{PRIEKŠV ĀRDS}

Pie lasītājiem dodas ceturtais krājums ar saturiski ietilpīgo latīṇu nosaukumu ANTIQUITAS VIVA. STUDIA CLASSICA.

Eiropas klasiskās senatnes pētījumi ir Latvijas Universitātes (LU) Humanitāro zinātṇu fakultātes Klasiskās filolog̣ijas katedras un attiecīgo studiju programmas dalībnieku uzdevums un kopdarbs, arvien ar interesi uzņemot un piesaistot arī citu valstu un augstskolu kolēǵu pētnieciskā darba rezultātus.

Antīkās kultūras vērtību dzīvīgums (antiquitas viva!) šoreiz meklēts un apcerēts izglītības un izglìtošanās jomā, kura bijusi būtiska sabiedrības attīstības ass grieḳiski romiskajā pasaulē pirms daudziem gadsimtu desmitiem un turpina tāda būt mūslaikos - ar līdzīgām vai jaunām aktualitāšu šķautnēm. Ja tikai esam gatavi to saprast, novērtēt un skatīt arī vēsturiskā griezumā. Jo - kā pauž slavenā latīnu sentence: historia est magistra vitae, dzìvē mācāmies (ir vērts mācīties) no vēstures, no gūtās pieredzes.

Minētā tematika nodrošinājusi krājuma pirmās - zinātnisko rakstu daḷas saturu: tajā piedāvāti trīspadsmit pētījumi, kuros iztirzāti dažādi izglītības/izglītošanās ПAI $\triangle E I A$ aspekti un atklāts gan vispārteorētisks, gan kāda noteikta kultūrfenomena, gan konkrēta teksta materiāla izvērtējums izglītības/izglītošanās diskursā. Cerams, ka lasītājs katrā rakstā radīs apliecinājumu tam, ka antīkā pasaule radījusi un îpašā gaismā tālākajiem laikiem nodevusi cilvēka izcilāko guvumu - izglītību.

Krājuma otro daḷu - ANNĀLES - tradicionāli veido gaduraksti, proti, pēdējo triju gadu fakti un notikumi Latvijas klasisko filologu akadēmiskajā dzīvē. Tā kopumā vērtējama kā bagātīga: aizstāvētas trīs doktora disertācijas (divas Latvijā un viena Zviedrijā), klasiskās filologiijas bakalaura un maǵistra grādu LU ieguvuši 66 studenti, vairākiem būtiskiem klasiskās senatnes kultūrfaktiem tikuši veltīti publicitātes pasākumi, apmeklēti un radošus iespaidus devuši svarīgi starptautiski forumi, novērtētas atsevišķas filoloǵijas jomai svarīgas publikācijas. 
Krājuma veidotāiji ir gandarīti, ka ieguldījumu gan krājuma zinātniskajā, gan annāḷu daḷā snieguši kā nozares profesori un docētāji, tā studenti, maǵistranti un doktoranti un arī klasiskās filoloǵijas programmas absolventi.

Diemžēl krājuma aptvertais laikposms bijis ne vien dāsns, bet arī skarbs, 2013. gada ruden̄i aizvedot mūžības ceḷos izcilu filoloǵi, daudzu klasisko filologu paaudžu izglītotāju un audzinātāju Ināru Ķemeri, kurai veltītie atceres vārdi veido atsevišḳu sadaļu krājumā.

21. gadsimta otrajā desmitgadē redzams, ka nav vienkārši un pašsaprotami apliecināt un pārliecināt, ka humanitārās zinības ir sabiedrības izglītotības pamatgarants.

Klasiskām vērtībām jābūt ieraudzịtām un zināmām; optimistisku drošības sajūtu šai ziṇā rada arvien jaunu klasisko filologu paaudžu ienākšana Latvijas sabiedrībā un iepriekšèjo paaudžu atbalsts un sadarbỉba ar tām.

Latvijas Universitāte ir vienīgā augstskola Latvijā, kur pārstāvētas klasiskās filoloǵijas studijas un pētniecība.

Krājuma veidotāji ir pateicīgi LU Akadēmiskajam apgādam par sadarbību antīkās pasaules un klasiskās filoloǵijas pētījumu publicitātes nodrošināšanā, kā arī Griekijas Republikas Kultūras un sporta ministrijai un ERAF projekta "Atbalsts Latvijas Universitātes starptautiskās sadarbības projektiem un citiem starptautiskās sadarbības pasākumiem zinātnē un tehnoloğijās" Nr. 2010/0202/2DP/2.1.1.2.0/10/APIA/VIAA/013 īstenotājiem LU par finansiālu atbalstu krājuma tapšanā.

Ilze Rūmniece 


\section{FOREWORD}

On its way to the reader is the fourth collection under the capacious Latin title: ANTIQUITAS VIVA. STUDIA CLASSICA.

The University of Latvia (UL) Department of Classical Philology of the Faculty of Humanities as well as everyone involved in the respective study programme see European classical antiquity studies as their common task and joint effort, always open to and inviting colleagues of other countries and universities to share their research results.

This time the vitality of ancient cultural values (antiquitas viva!) was sought and considered in the field of education and learning, which was an essential social development axis in the Graeco-Roman world centuries ago and continues to be such in our time - with similar or new topical highlights. We should be ready to understand, appreciate and see this also in the historical context, because - according to the famous Latin maxim historia est magistra vitae - we learn from history, from previous experiences, and such learning is worthwhile.

Education-related topics provide the content of the first part of the book - scholarly articles. This part offers thirteen studies that deal with a variety of educational/learning $\Pi A I \triangle E I A$ aspects and present either general theoretical evaluation or assessment of a specific cultural phenomenon or a particular text in the educational/learning discourse. It is hoped that the reader will find evidence in each article for the role of the ancient world in creating and leaving an illuminating legacy of the greatest human accomplishment - education.

The second part of the book, ANNALS, traditionally comprises the facts and events in the academic life of Latvia's classical philologists over the last three years. All in all, it has been productive: three doctoral theses have been defended (two in Latvia and one in Sweden), Classical Philology bachelor's and master's degrees have been conferred on 66 students of the University of Latvia, a number of publicity events 
have been devoted to key cultural facts of classical antiquity, consequential and inspiring international forums have been attended and several important publications in the field of philology have been recognized.

The editors of this issue are satisfied that professors and lecturers in the field as well as bachelor, master, doctoral students and the Classical Philology programme graduates have contributed to both the research part and the annals.

Unfortunately, the period that the collection covers was not only generous but also harsh: in the autumn of 2013 Ināra Kemere, an outstanding philologist, educator and teacher of several generations of classical philologists, passed away.

The second decade of the $21^{\text {st }}$ century shows that there is no simple and self-explanatory way to acknowledge and convince that the humanities constitute the fundamental guarantee of an educated society.

Classical values must be noticed and known; an optimistic sense of security in this respect comes from the advent of new generations of classical philologists in the Latvian society, in cooperation with and supported by more experienced colleagues.

The University of Latvia is the only institution of higher education in Latvia which offers Classical Philology studies and research.

The editors are grateful to the Academic Press of the University of Latvia for supportive cooperation in assisting in the publicity of the studies of the ancient world and classical philology, as well as to the Greek Ministry of Culture and Sport, and to the UL participants in the ERDF project "Support to the University of Latvia international cooperation projects and other measures of international cooperation in science and technology" (No. 2010/0202/2DP/2.1.1.2.0/10/APIA/VIAA/013) for financial support. 


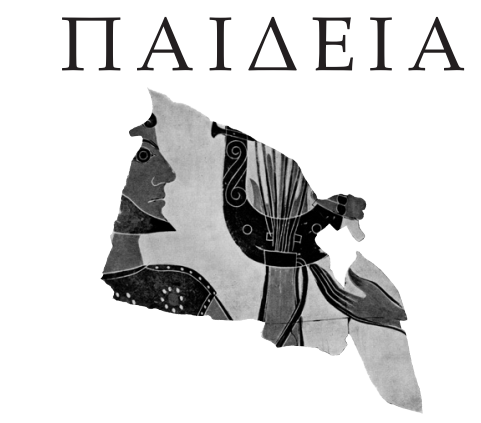

\section{VITA PAPARINSKA}

Latvijas Universitāte, Latvija

\section{PRAGMATISMS IZGLĪT ĪB $\bar{A}$ - MŨSDIENU NOVIT ĀTE VAI ANTİKĀS PASAULES MANTOJUMS?}

\section{İss kopsavilkums}

Rakstā sastatījumam ar mūsdienu izglītības pragmatisma uzstādījumu, izmantojot antīkos avotus - slavenā romiešu oratora Cicerona traktātus Par oratoru un Orators -, tiek apzināti izglītības mērḳi un saturs Senās Romas kultūrtelpā. Akadēmiski izglītotais Cicerons, rētorikas pārzinātājs un runas mākslas praktiķis, apzinoties sava laika romiskās izglītības sistēmas sašaurinājumu runas prasmes apgūšanas virzienā, piedāvā izglītības modeli, kurā salāgotas vispārējās, t. i., akadēmiskās, zinības ar runas mākslas apguvi. Romiskā kultūrvide ar tās orientāciju uz akadēmisko zinību praktiskā izmantojuma potenciālu Cicerona izglītības modelī nosaka runas mākslas prevalenci.

Atslēgvārdi: Cicerons, izglītība, orators, akadēmiskās zinības, runas māksla.

Sengrieḳu izglītības sistēmas uzdevumus formulējis Atēnu slavenais rētors Isokrats (Isocrates, 436.-338. g. p. m. ē.). Tie ir - iemācīt jauno cilvēku

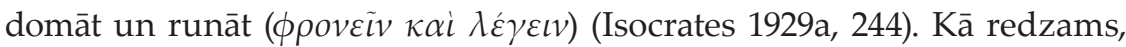
Isokrats atzīst tādu izglītības modeli, kura komponenti ir akadēmiskās zināšanas un runas prasme. Prioritāra nozīme ir akadēmisko zināšanu atzaram, kuru Isokrats apzīmē ar terminu „filozofija” ( $\varphi$ ı to saprotot cildenākās un vērtīgākās nodarbes - prāta attīstīšanu, zināšanu meklēšanu un apguvi (Isocrates 1929a, 304; 1929b, 209). Tādā pašā 
nozīmē terminu "filozofija” lieto grieķu vēsturnieki Hērodots (Herodotus, c. 484.-425. g. p. m. è.) un Tūkidīds (Thucydides, c. 460.-395. g. p. m. è.) (Herodotus 1920, 1.30.2; Thucydides 1928, 2.40.1).

Senās Griekijas kultūrtelpa ar tās harmoniska cilvēka ideālu, cilvēku, kuru raksturo $\kappa \alpha \lambda$ « $\dot{\alpha} \gamma \alpha \theta i \alpha$, fiziskais un garīgais skaistums, ir visai tāla no mūsdienu sabiedrības mērḳiem un centieniem savu mērḳu sasniegšanai. Pēdējos gados tiek atklāti formulēts un praksē pakāpeniski īstenots izglìtības mērḳu un satura pielāgojums pragmatisma virsuzstādījumam. Tas rosina dažādus jautājumus - kur un kad saskatāmi šīs tendences sākumi? Vai pragmatisms izglītībā ir mūsdienu novitāte vai antīkās pasaules mantojums? Meklējot saskares punktus starp izglītības mērķiem un saturu antīkajā pasaulē un mūsdienās, piemērotāks avots kopsakarību apzināšanai ir Senā Roma. Daḷeji būdama Grieḳijas tradīciju pārṇēmēja un daḷeji savas īpašās vērtību sistēmas radītāja, Roma no Grieḳijas atšķiras ar pragmatisku, dzīves praktiskajiem aspektiem tuvāku pasaulredzējumu un no tā izrietošiem idejiskajiem uzstādījumiem garīgajā telpā, tostarp izglìtībā.

Romiskās izglītības un izglītošanas dažādi aspekti ir apskatīti vairākos nozīmīgos tekstos - Cicerona (Marcus Tullius Cicero, 106.43. g. p. m. ē.) traktātos Par oratoru (De oratore) un Orators (Orator), nedaudz arī traktātā Par atrašanu (De inventione), Kvintiliāna (Marcus Fabius Quintilianus, c. 35.-100. g.) traktātā Oratora audzināšana (Institutio oratoria) un Tacita (Publius / Gaius Cornelius Tacitus, c. 56.-117. g.) traktātā Dialogs par oratoriem (Dialogus de oratoribus). Visi šie teksti ir rētorikas iztirzājumi. Nevienā no šiem tekstiem izglītības tēma nav prioritāte, un ar izglītību saistītais problēmloks tiek skatīts rētoriskās jeb oratoram nepieciešamās izglītības un oratora izglītošanas prakses aspektā.

Cicerons traktātā Par oratoru raksturo īpašās oratora prasmes, sakot, ka cilvēks, kas patiesi ir pelnījis šo cildeno vārdu, ir tas, kurš par jebkuru jautājumu runā apdomāti, sakārtoti, skaisti, precīzi un turklāt cieņpilni (Cicero 1942a, 1.64). Tomēr jāuzsver, ka terminam „orators” Romas pasaulē bija specifiska nozīme - tas apzīmē jebkuru valsts dzìvē iesaistījušos pilsoni, vienalga, vai viņš darbojas politikā, tieslietās vai militārajā sfērā. Tādējādi romiešu tekstos iztirzātajam oratoram paredzētajam izglītības modelim ir plašs izmantojums. Tas var tikt attiecināts uz jebkuru pilsoniski aktīvu un atbildīgu romieti.

Tomēr, neṇemot vērā vienojošo koplīniju - uzmanības centrējumu uz oratoru -, visi minētie romiešu teksti, kuros apskatīti izglītības un 
izglītošanās jautājumi, ir atšḳirīgi. Vismazāk uzmanības izglītības jautājumiem velta Tacits savā Dialogā par oratoriem. No trīs sarunas dalībniekiem par jauniešu izglītošanu rētorikas skolās runā tikai viens Mesala, turklāt viṇa izteikumi ir virspusēji un secinājumi - naivi. Kvintiliāns traktātā Oratora audzināšana galvenokārt iztirzā rētorikas un runas prakses jautājumus. Raksturojot vēlamo rētoriskās izglìtības saturu un oratora izglītošanas gaitu, viņš galvenokārt domā par oratoru tiesvedībā iesaistītās puses pārstāvi tiesā.

Cicerona traktāts Par oratoru (55. g. p. m. ē.), kura darbība risinās 91. g. p. m. ē., ir saruna, kurā piedalās sava laika izcilākie oratori - Krass, Antonijs, Skaivola, Sulpikijs, Kota, Katuls un Strabons. Sarunas tēma ir ideāls orators - kādam tam būtu jābūt un kā tādu var veidot. Pirmās grāmatas sākumā Cicerons raksturo savu pozīciju (Cicero 1942a, 1.16-33), un sastatijums ar to ḷauj vienu no sarunas dalībniekiem - Krasu - uzskatīt par Cicerona uzskatu paudēju (Clarke 1996, 50-51). Ideāla oratora tēma, kaut arī lielākā daḷa teksta ir rētorikas iztirzājums, tiek risināta arī traktātā Orators (46. g. p. m. è.), un te Cicerons runā savā vārdā.

Tādējādi vispilnīgāko priekšstatu par romiskās izglītības saturu sniedz Cicerona teksti. Turklāt Cicerons ir pietiekami daudzpusīga, spilgta, kompetenta personība, lai viņa viedoklis par jebkuru jautājumu būtu apzināms un ņemams vērā. Ne mazāk svarīgs ir fakts, ka Cicerona izglītības modelis nav tikai prāta spēle, bet tas sakṇojas paša autora izglītotības pieredzē.

Cicerona iegūtā izglītîba bija vienlaikus tipiska viṇa laika labdzimušam pārtikušam romietim un atšķirīga. Tipiska tā bija tādā ziṇā, ka Cicerons apguva tiesību zinātṇu praktiskās zināšanas, vērojot darbā ievērojamus juristus. Cicerona priekšrocība salīdzinājumā ar viṇa laikabiedriem bija akadēmiskā izglītība - studijas pie Jaunās Akadēmijas vadītājiem Filona (Philo, c. 154./3.-84./3. g. p. m. ē.) ${ }^{1}$ un Antioha (Antiochus, c. 125.-68. g. p. m. ē.) $)^{2}$ un juristam un politiķim nepieciešamās runas mākslas apguve pie slavenā rētorikas skolotāja Apollonija Molona (Apollonius Molon, 1. gs. p. m. ē.) ${ }^{3}$ Rodas salā. Nozīmīga Cicerona izglītîbas daḷa ir bijusi rētorikas tekstu studijas (Clarke 1996, 51-52; Grube 1995, 169-170). Savos tekstos viņš nereti atsaucas uz Aristoteḷa un Isokrata rētorisko domu (Cicero 1949, 1.7, 2.4, 2.7; Cicero 1999, 4.10; Cicero 1942a, 2.160; Cicero 1942b, 3.80; Cicero 2001b, 1, 14, 62, 27, 32, 36 etc.), pat norādot, ka traktātā Par oratoru iestrādātas gan šo autoru, gan citu seno domātāju atziṇas par rētoriku (Cicero 2001a, 1.9). 
Paša apgūto zināšanu apjoms un saturs Ciceronam ir pamats salīdzinājumam un atskaites punkts, sastatījums ar to var skaidrāk parādīt oratoram nepieciešamās zinības un prasmes.

Traktātā Par atrašanu (c. 92./88. g. p. m. è.) Cicerons saka:

Ilgas pārdomas mani patiesi noved pie š̀̃ galvenā secinājuma: es uzskatu, ka gudrība bez runas prasmes ir maz noderīga sabiedrībai, bet runas prasme bez gudrības lielāko tiesu nodara l̦aunu, nekad - labu. (Cicero 1949, 1.1)

Zīmīgi, ka šajā jaunības gadu darbā, kurā iztirzātas rētorikas metodes un kuru vēlāk Cicerons nosauks par nepilnīgu un neizstrādātu (Cicero 1942a, 1.5), atklājas Cicerona nemainīgā pārliecība, ka oratoram nepieciešama gan gudrība, gan runas prasme (Grube 1995, 170). Šo jautājumu Cicerons izvērš arī savos brieduma gadu traktātos Par oratoru un Orators, tikai tad viṇš gudrības un runas prasmes salāgojumu iztirzā sasaistē ar oratora izglìtības saturu:

Tā kā runai veidoties un plūst liek lietu pārzināšana, neviens nevar büt slavens orators, ja nav apguvis zināšanas par visām svarīgajām lietām un mākslām. Ja orators lietu nav izzinājis un izpratis, viņa runa būs tukša un gandrīz bērnišķiga. (Cicero 1942a, 1.20)

Atškirīibā no šauri specializētās, uz runas prasmes apguvi orientētās izglītības, kuru piedāvāja rētorikas skolas, kuras Cicerons nicīgi nosauc par oratoru „ražotavām” (Cicero 2001b, 12), Cicerons oratoram nepieciešamās izglītības saturam uzstāda augstas prasības. Viṇa izglītības modelis saturiski ir plašs un daudzveidīgs. Pēc Cicerona domām, oratoram ir jāapgūst akadēmiskās zinības un runas māksla:

Ir jāapgūst zināšanas par loti daudzām lietām, bez kurām vārdu plūsma ir tukša un izsmiekla vērta; pati runa ir jāveido, ne tikai izvēloties vārdus, bet arī tos izkārtojot; ir dziļi jāpārzina visas emocijas, kuras cilvēku ciltij ir dotas no lietu dabas, tāpēc ka viss daiļrunas spēks un mērķ̧is ir pilnībā atkarīgs no spējas nomierināt vai satraukt savu klausītāju prātus; jāpievieno valdzinājums un asprātība, brīva cilvēka cienīga erudīcija, ātrums un ìsa izteiksme gan atbildēs, gan izaicinājumos apvienojumā ar izsmalcinātu tìkamību un valodas tìrību; tāpat ir jāzina visa pagātne un piemēru spēks; nedrīkst atstāt novārtā likumu un civiltiesību zināšanas. (Cicero 1942a, 1.17-18)

Abas oratora izglītošanas dạ̣as - akadēmiskā joma un runas māksla - ir jāsalāgo. Tomēr, tā kā rētorikai veltītajos traktātos Cicerons lielāku uzmanību veltī runas mākslai un rētorikas dažādu aspektu 
iztirzājumam, redzams, ka oratora izglītošanā par prioritāro Cicerons atzīst tieši runas mākslas apguvi. Runas prasme, kā uzskata Cicerons, ir tas prasmju kopums, kurš kā akadēmisko zināšanu papildinājums oratoru paceḷ augstāk par visu citu jomu zinātājiem (Grube 1995, 170).

No paša apgūtajām zinību jomām īpaši augstu Cicerons vērtēja filozofiju. Zīmīgs ir viņa izteikums: mani par oratoru, ja vien es tāds esmu, un arī tādu, kāds es esmu, ir veidojušas nevis oratoru ražotavas, bet Akadēmijas pastaigu laukumi (Cicero 2001b, 12). Tādēḷ Cicerona uzskatus par akadēmisko zināšanu nozīmi labi raksturo tieši filozofijas un runas mākslas sastatijums.

Lai cik vēlamas oratoram ir zināšanas filozofijā (Cicero 1942a, 1.89-93), ir jāsaprot, ka filozofija ir tikai viena no zinību jomām (Cicero 2001b, 14-16). Oratoram nav jābūt filozofam. Turklāt orators ir pārāks par filozofu, jo filozofam nepieciešama tikai gudrība, bet orators sevī apvieno gan gudrību, gan runas prasmi (Cicero 1942b, 3.142-143). Tāpat oratoram nepieciešamas dzejnieka spējas aizraut un aizkustināt auditoriju, bet tās nav būtiskas filozofam (Cicero 1942a, 1.70-71).

Mūsdienu izglītības satura sastatǐšanai ar antīko pasauli lielāku interesi rosina akadēmisko zināšanu daḷas saturs un apjoms.

Cicerona tekstos ir daudz izteikumu, kas rāda, ka viņš augsti vērtē izglītību, kuru viṇam bija bijusi iespēja iegūt. Tomēr atzinīgās atsauces uz savu izglītības pieredzi, cieṇpilnā attieksme pret Akadēmijas mācību saturu, apzināšanās, ka Akadēmijā apgūtās akadēmiskās zināšanas ir palīdzējušas viṇam veidot karjeru, kura izrādījusies veiksmīgāka nekā daudziem par viṇu augstākas izcelsmes romiešiem, nenozīmēe, ka Cicerons savas izglìtības modeli absolutizē. Cicerons labi apzinās, ka viṇa izglītotība ir unikāla un nav pielīdzināma vidusmēra romieša izglītībai. Tādēḷ viṇš piedāvā pragmatisku izglītības modeli. Šì modeḷa pamatuzstādījums ir - izglītība nav mērḳis, bet līdzeklis karjeras veidošanai. Un zīmīgi - raksturojot tīri teorētisku zinību jomu nepieciešamību, Cicerons to pamato ar plaša praktiskā izmantojuma iespējām. Akadēmiskās zināšanas var izrādīties lietderīgas praktiskajā darbībā - jurisprudencē, politikā, militārajā jomā -, nodrošinot intelektuālo pārākumu salīdzinājumā ar mazāk zinošajiem kolēǵiem un juridiskā vai politiskā vārdu kaujā uzveicot savu mazāk izglītoto pretinieku (Grube 1995, 171, 174-175; Walker 2000, 80-83).

Arī savā oratora izglītošanas modelī filozofijai Cicerons nešaubīdamies ierāda paliekošu vietu (Cicero 2001b, 14-17), sakot, ka par .. 
oratoru .. nevar kḷūt bez filozofijas zināšanām, .. jo bez tām neviens nevar plaši un izvērsti runāt par dažādām nozīmīgām lietām (Cicero 2001b, 14). Šīs nozīmīgās lietas ir religija, nāve, dievbijība, dzimtenes mīlestība, labais un ḷaunais, tikums un netikums, pienākums, sāpes, bauda, prāta satraukumi un maldības (Cicero 2001b, 118). Filozofijas zināšanām ir arī praktiskais aspekts - tās oratorā veidos prasmes klausītājus pārliecinoši uzrunāt, viṇus aizkustināt un iespaidot (Cicero 1942a, 1.219). Savus argumentus Cicerons papildina ar faktiem no reālās dzìves. Piemēram, traktātā Orators (Cicero 2001b, 15) Cicerons piemin izcilus runātājus, kuru runas prasmi bagātinājušas zināšanas filozofijā, - Periklu (Pericles, c. 495.-429. g. p. m. ē.), kurš mācījies pie filozofa Anaksagora (Anaxagoras, c. 510.-428. g. p. m. è.), un Dēmostenu (Demosthenes, 510.-428. g. p. m. è.), kurš mācījies pie filozofa Platona (Plato, 424./423.- 348./347. g. p. m. ē.).

Zinību jomas nozīmīguma atzinums savijas ar pragmatisko izmantojuma aspektu, kad Cicerons runā par vēsturi. No vienas puses, vēsture ir lieciniece laikiem, patiesības gaisma, atmiņas iedzīvinātāja, senatnes vēstnese (Cicero 1942a, 2.36), un Cicerons patētiski izsaucas:

Patiesi, nezināt to, kas noticis pirms tavas dzimšanas, nozīmē vienmēr būt bērnam. Kas ir cilvēku dzīve, ja atmiņas par sendienām to nesavij ar senču dzĩvi? (Cicero 2001b, 120)

Turpinājums ir prozaisks. Vēstures zināšanas oratoram ir noderīgas sendienu pieminējums un senatnes piemēri runai piešķirs iespaidīgumu un pārliecinātspēju, kā arī priecēs klausītājus. Tomēr plašas vēstures zināšanas oratoram nebūt nav nepieciešamas - pietiekams materiāls vēstures apguvei, kā norāda Cicerons, ir viņa drauga Atika (Titus Pomponius Atticus, 112./109.-35./32. g. p. m. ē.) sarakstītais Romas vēstures kompendijs (Cicero 1928, 1.5).

Vēl izteiktāk praktiskā izmantojuma aspekts uzsvērts, kad Cicerons runā par ètikas - dzīves un tikumu zinības - apguvi (Cicero 1942, 1.68-69). Ėtikas zināšanas dos iespēju oratoram izprast un ietekmēt savu klausītāju emocijas, kā arī mācīs runāt par mūžam nemainīgām tēmām par dieviem, dievbijību, saskaṇu, draudzību, par kopīgajām pilsoṇu, cilvēku un tautu tiesībām, par taisnīgumu, savaldību, dvēseles diženumu un visa veida tikumu (Cicero 1942, 1.56).

Pārliecība par log̣ikas un dabas zinātnes nepieciešamību Ciceronam veidojas pakāpeniski. Traktātā Par oratoru viņš uzskata, ka orators bez šìm zinībām var iztikt (Cicero 1942a, 1.68). Vēlāk traktātā Orators 
Cicerons saskata šo zinību praktiskā izmantojuma iespējamību. Logika ir noderīga diskusijā (Cicero 2001b, 114, 118), bet dabas zinātne - debesu ḳermeṇu pārzināšana - ḷaus attīstìt cildenāku izteiksmes veidu (Cicero 2001b, 119).

Interesantas Cicerona izglītības modelī ir atziņas par jurisprudences apguves nepieciešamību. Tiesību zināšanas oratoram, kurš uzstājas tiesā, liekas pašsaprotamas. Tomēr, kā redzams pēc Cicerona tekstiem, tā tas nebija. Rētorikas skolās jurisprudence netika mācīta. Nereti prāvnieki bija gatavi tiesāties par likuma burtu, bet viṇi nesaprata likuma būtību, vai arī vin,iem nebija pietiekama priekšstata par tiesas procesu (Clarke 1996, 57). Tādēḷ Cicerons uzsver, ka nekas oratoram nav tik apkaunojošs kā likumu nezināšana (Cicero 2001b, 120; Cicero 1942, 1.169, 173, 184).

Liekas, ka pat šāds uz praktiskā izmantojuma potenciālo nepieciešamību orientēts izglìtības modelis romiešiem ir novitāte, kuru sabiedrība neizprot un nav gatava pieņemt, vismaz ne pilnībā. Citādi nevar izskaidrot Cicerona centienus atkal un atkal mēǵināt rast argumentus, lai pārliecinātu lasītājus, ka izglītības modelī ir jāparedz akadēmiskas studijas.

Labs piemērs šajā sakarā ir kāda epizode traktātā Par oratoru.

Krasam, kurš apgalvo, ka oratoram ir nepieciešamas plašas akadēmiskas zināšanas, iebilst sarunas biedri Skaivola un Antonijs. Skaivola uzskata, ka praksē plašu vispārēju zināšanu ideāls nav sasniedzams un ka oratoram ir labi jāpārzina tieslietas. Antonija skatījumā oratoram ir jābūt spējīgam prasmīgi lietot daiļrunu tiesu zālēs un politiskajās sapulcēs, un viņš noraida Krasa uzskatu, ka orators ir cilvēks, kurš ir spējīgs labi runāt par jebkuru tēmu. Protams, ir jābūt pietiekami zinošam par iztirzājamo tēmu, bet dziḷas zināšanas nav nepieciešamas. Kā par sevi saka Antonijs, viņš brīvajā laikā lasot vēsturnieku, filozofu un dažu dzejnieku darbus, lai viṇa runa no šì materiāla iegūtu krāsainību, tieši tāpat kā viņa seja, staigājot saulē, iegūst iedegumu. Citādi viņš pievēršot maz uzmanības šādiem tekstiem (Cicero 1942a, 2.59-61).

Nobeigumā ir jāatgriežas pie sākumā uzdotā jautājuma, vai pragmatisms izglītībā, orientācija uz t. s. „darba tirgus prasībām” un akadēmiskās izglītības vērtības apšaubīšana ir mūsdienu novitāte vai antīkās pasaules mantojums. Cicerona teksti parāda, ka tā ir likumsakarība pragmatiski noskan,otā sabiedrībā. Tādēl Cicerona uzskatiem par izglīî̄bu ir traǵiska pieskaņa. Teorētiski atzīdams par optimālu Isokrata akadēmiskās izglītības idejas un runas mākslas apvienojumu, Cicerons šo ideālu ir spiests pielāgot sava laika realitātei. Realitāte prasa zināšanas 
un prasmes, kurām ir praktisks izmantojums. Akadēmiskai izglītībai ir pakārtota nozīme.

\section{ATSAUCES}

1 Filons no Larisas - grieḳu filozofs, Romā lasīis lekcijas par rētoriku un filozofiju. Darbi nav saglabājušies.

2 Antiohs no Askalonas - grieḳu filozofs. Cicerons pie viṇa mācījies Atēnās. Darbi nav saglabājušies.

3 Apollonijs Molons - ḷoti slavens grieḳu rētorikas skolotājs un orators, rētorikas skolas Rodas salā izveidotājs un vadītājs.

\section{BIBLIOGRĀFIJA}

\section{Antīkie avoti}

Cicero. Letters to Atticus. Cicero. Volume XII. Letters to Atticus 1-89. Cambridge Massachusetts - London - England : Harvard University Press, 1999.

Cicero. Letters to Friends. Cicero. Volume XXV. Letters to Friends 1-113. Cambridge Massachusetts - London - England : Harvard University Press, 2001a.

Cicero. On Invention (De Inventione). Cicero. Volume II. On Invention (De Inventione). The Best Kind of Orator De Optimo Genere Oratorum). Topics (Topica). Cambridge - Massachusetts London - England : Harvard University Press, 1949.

Cicero. On the Laws (De Legibus). Cicero. Volume XVI. On the Republic (De Re Publica). On the Laws (De Legibus). Cambridge - Massachusetts - London - England : Harvard University Press, 1928.

Cicero. On the Orator (De Oratore). Cicero. Volume III. On the Orator (De Oratore). Books 1-2. Cambridge - Massachusetts - London - England : Harvard University Press, 1942a.

Cicero. On the Orator (De Oratore). Cicero. Volume IV. On the Orator (De Oratore). Book 3. On Fate (De fato). Stoic Paradoxes (Paradoxa Stoicorum). On the Divisions of Oratory (De Partitione Oratoria). Cambridge - Massachusetts - London - England : Harvard University Press, $1942 b$.

Cicero. Orator. Cicero. Volume V. Brutus. Orator. Cambridge - Massachusetts - London England: Harvard University Press, 2001b.

Herodotus. The Persian Wars. Herodotus. The Persian Wars. Volume I. Books 1-2. CambridgeMassachusetts - London - England : Harvard University Press, 1920.

Isocrates. Antidosis. Isocrates. Volume II. On the Peace. Areopagiticus. Against the Sophists. Antidosis. Panathenaicus. Cambridge - Massachusetts - London - England : Harvard University Press, 1929a.

Isocrates. Panathenaicus. Isocrates. Volume II. On the Peace. Areopagiticus. Against the Sophists. Antidosis. Panathenaicus. Cambridge - Massachusetts - London - England : Harvard University Press, 1929b.

Thucydides. History of the Peloponnesian War. Thucydides. History of the Peloponnesian War. Volume I. Books 1-2. Cambridge - Massachusetts - London - England : Harvard University Press, 1928.

\section{Zinātniskā literatūra}

Clarke, M. L. Rhetoric at Rome. A Historical Survey. London - New York : Routledge, 1996. 
Grube, G. M. A. The Greek and Roman Critics. Indianapolis - Cambridge : Hackett Publishing Company, 1995.

Walker, J. Rhetoric and Poetics in Antiquity. Oxford : Oxford University Press, 2000.

Vita Paparinska, University of Latvia, Latvia

PRAGMATISM IN EDUCATION - MODERN NOVELTY OR LEGACY OF THE ANTIQUITY?

The article discusses current pragmatism in education against the background of classical sources - the famous Roman orator Cicero's treatises De Oratore and Orator - to identify the aims and contents of education in the cultural space of Ancient Rome.

The scope and content of Cicero's own knowledge is the basis for comparison, reference and juxtaposition to show the orator the necessary knowledge and skills. Recognizing that his own learning is unique and not comparable to the education of an average Roman, as well as admitting the limitations of the Roman system of education of his time in the area of rhetorical skills, Cicero offers an education model in which the art of speech is aligned with the general, i.e. academic sciences (philosophy, ethics, logic, history, natural science, law). In describing the need for academic knowledge, Cicero supports this idea with its wide applicability in practice - in law, politics, military affairs - thus securing one's intellectual superiority over a rival or an opponent.

Cicero's education model shows that, by admitting the optimal combination of academic education and rhetoric, Cicero subjects this alignment to the reality of his space and time, which requires practically applicable knowledge and skills. In this model of education, academic knowledge is of a secondary importance. 


\section{HARIJS TUMANS}

Latvijas Universitāte, Latvija

\section{HELLĒṆU DISKUSIJAS PAR PAIDEIJU}

\section{İss kopsavilkums}

Šajā rakstā piedāvāts īss pārskats par to, kā laika gaitā mainījās seno grieḳu priekšstati par paideiju un kādas asas diskusijas grieḳu kultūras telpā izraisīja izmainnas izpratnē par izglītību. Sākotnēji šì tēma nekādus jautājumus neizraisìja, jo grieḳiem bija acìmredzami, ka paideijas būtība ir kalpot citiem cilvēkiem un audzināt viṇus. Kā parādīja Verners Jēgers, līdz pat 5. gs. vidum p. m. è. visa grieķu kultūra nodarbojās ar audzināšanu. Taču jaunās dzīves vēsmas izraisīja dziḷas pārmaiṇas domāšanas veidā, radot jaunas vērtības, kuras aktīvi sludināja sofisti. Sofisti ne tikai pauda jaunas idejas, bet arī radīja jaunu izglìtības koncepciju, saskaṇā ar to izglītība tika atrauta no audzināšanas, pārvērsta par profesionālu sagatavošanu, un par tās mērḳi tika pasludināta naudas pelnī̌sana. Vairāki tā laika teksti rāda mums šo divu paideijas koncepciju konfrontāciju, bet visnopietnākā šo ideālu sadursme notika ideju cīṇā starp sokratisko domu, kas pārstāvēja tradicionālo vērtību sistēmu, un jauno, savā būtībā postmoderno sofistisko ideologiiju.

Atslēgvārdi: izglītība, audzināšana, vērtības, mērḳis, kalpošana, peln̄išana.

Šeit paideija tiks saprasta plašākā nozīmē - ne tikai kā izglīìiba/izglītošanās, bet arī kā audzināšana, kas vienmēr, līdz pat neseniem laikiem, bija ḷoti svarīgs un bieži vien pats svarīgākais izglìtības uzdevums. Tādēl hellēṇu diskusijas par paideiju šajā kontekstā nozīmē diskusijas par audzināšanas/izglītības mērḳiem un jēgu. Ilgu laiku grieḳu kultūras telpā nebija publisku diskusiju par šo tēmu, jo acīmredzot paideijas būtība likās pašsaprotama. Īsumā to var formulēt l̦oti vienkārši: mācīt kriet-

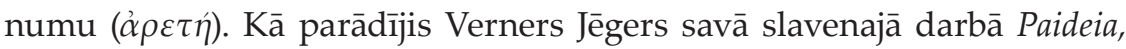
visa sengrieḳu kultūra būtībā nodarbojās ar paideiju šādā izpratnēể. Par svarīgāko mākslu, kā zināms, griek̦i uzskatīja vārda mākslu, tādēl tieši literatūra dod mums iespēju izsekot tam, kā Helladas zemē attīstījās priekšstati par paideijas mērḳiem un uzdevumiem.

Tātad no pašiem pirmsākumiem ilgā laika posmā grieḳu literatūra kalpoja krietnuma ideālam. Protams, izpratne par krietnumu laika gaitā mainījās, arī autoru izpratne varēja nedaudz atškirities, tomēr palika spēkā vadošā tieksme - ar savu daiḷradi būt noderīgam (t. i., 
audzinošam) citiem cilvēkiem. Piemēram, Homērs (8. gs. p. m. ē.) sludināja aristokrātisko krietnuma ideālu, savukārt Hēsiods (8. gs. p. m. ē.) uzstājās ar alternatīvām mietpilsoniskām vērtībām. Viens pirmajā vietā lika militāru krietnumu, bet otrs - taisnīgumu un godīgu darbu. Katrs no viṇiem mācīja savu dzìves ideālu, un pārliecību abi smēlās savā iedvesmā, kurai bija sakrāls avots - Mūzas. Tajos laikos valdīja uzskats, ka dzejnieks saṇem dzejas dāvanu no pašiem dieviem (Od., VIII, 44 ), tieši tādēḷ viņš tiek īpaši godāts tautā (Od., XIII, 28)². Katrs no viṇiem varēja teikt par sevi ar episkā dzejnieka Fēmija vārdiem: kāds mūūīgais dzimstot man sirdī ielicis dažādas dziesmass (Od., XXII, 347f ). Tādā veidā arī Homērs un Hēsiods uzstājās kā dievišķās patiesības nesēji cilvēku pasaulē. Viṇi audzināja vērtības, un tādẹl viṇus patiešām var saukt par lielajiem grieḳu skolotājiem ${ }^{4}$. Pie tam Homērs vēl nekādā veidā neizpauda savu personību, savu radošo es, taču Hēsiods uzstājās savā vārdā, jo viṇu iedvesmoja viṇa cēlās misijas apziṇa - nest patiesību l̦audīm. Nav nejauši, ka mūsdienu pētnieki dažreiz salīdzina viṇu ar Bībeles pravieti Amosu ${ }^{5}$.

Arhaikas laikmetā dzejnieki turpināja audzināt savos klausītājos krietnumu, katrs atbilstoši savai izpratnei un aktualitātei. Kallins (7. gs. p. m. ē.) un Tirtajs (7. gs. p. m. ē.) mācīja līdzpilsoniiem militāru drosmi un patriotismu, bet Alkajs (7. gs. p. m. ē.), Teognīds (6. gs. p. m. è.) un Pindars (522./518.-448./438. g. p. m. ē.) dziedāja par aristokrātu krietnumu, pie tam Teognīds, kā zināms, visu savu dzeju veltīja jauneklim Kirnam, kuram viņš mācīja dzīves mākslu. Savukārt Solons (640./635.559. g. p. m. e..) veltija savu dzejnieka talantu savas polisas politiskajai audzināšanai, mācot tai pilsonisku krietnumu. Viņš arī uzṇēmās pravieša lomu un savā didaktiskajā patosā apzināti atdarināja Hēsiodu' ${ }^{6}$ Nav nejauši, ka arī likumus viṇš vēlējās izdot vispirms poēmas formā (Plut. Sol., XIV) - tādā veidā viņš cerēja piešḳirt likumiem sakrālu statusu, pasniedzot tos kā atklāsmes aug̣̣us. Starp citu, arì filozofi ilgu laiku ar tādu pašu mērķi ietērpa savus sacerējumus poētiskā formā, jo arī viṇi uzstājās patiesības vēstnešu lomā.

Tātad arhaikas laikmetā dzejnieki un filozofi, proti, visi tie, kas rakstiski pauda savas domas citiem, uzṇēmās sabiedrības skološanas un audzināšanas funkciju. Viṇi veltīja savu daiḷradi sabiedrībai, mācot laikabiedriem savu izpratni par pasauli un lietām. Tādā veidā viṇi realizēja katrs savu paideiju.

Protams, ne visi dzejnieki nodarbojās ar paideiju, un visai drīz pēc Hēsioda liriskā dzeja sāka pievērsties subjektīvu emociju attēlošanai, 
bieži vien ar hedoniskiem motīviem. Šì dzeja vairs neko nemācīja un neaudzināja, tikai izklaidēja. Bet, ja par dzejas mērḳi kḷūst izklaide, tad nevar vairs būt runas par dzejnieka īpašo misiju. Tādēḷ ir likumsakarīgi, ka arhaiskā laikmeta izskaṇā un klasiskā laikmeta sākumā, kad liriskā dzeja, ar dažiem izṇēmumiem, bija pārvērtusies par „vieglo žanru”, paideijas funkcijas pārn,ēma drāma.

Kā zināms, grieḳu dramaturgi apstrādāja un pat modernizēja ${ }^{7}$ sen zināmos mītu sižetus, lai runātu par jautājumiem, kas bija aktuāli viṇu klausītājiem. Risinot uz skatuves morālas dabas jautājumus, dramaturgi uzstājās kā tautas audzinātāji ${ }^{8}$, un no viṇiem katru reizi tika sagaidīta kāda audzinoša pamācība.

Labs piemērs tam ir slavenais stāsts par Frīniha (6. gs. beigas - 5. gs. pirmā puse p. m. è.) izrādi Milētas ieņemšana, kas tika uzvesta Atēnās 494. g. p. m. è., t. i., pavisam drīz pēc pilsētas bojāejas karā ar persiešiem. Izrāde atstāja uz atēniešiem tik satriecošu iespaidu, ka visi skatītāji apraudājās. Mūsdienās tas tiktu atzìts par dramaturga spožu panākumu, bet toreizējie tiesneši autoram balvas vietā piesprieda prāvu naudassodu (1000 drahmu) un uz visiem laikiem aizliedza šīs lugas izrādīšanu (Hdt., VI, 21; Strab., XIV, 635 ). Tajā laikā pirmkārt tika vērtēta lugas audzinošā nozīme, tieši tādēḷ Frīnihs tika sodīts par to, ka lika skatītājiem pārdzīvot sāpīgas izjūtas, aizkustināja viṇus, bet atstāja auditoriju bez pozitīvas pamācības, t. i., bez paideijas. Tādēḷ šì luga pat netika atzìta par mākslas darbu... Starp citu, iespējams, ka tas ir pirmais gadījums grieḳu teātra vēsturē, kad dramaturgs bija atteicies no paideijas kā vadošā daiḷrades principa.

Zīmīgi, ka ar paideiju nodarbojās ne tikai traǵēdija, bet arī komēdija, kuras uzdevums žanra „viegluma” dēḷ būtu izklaidēt, nevis audzināt. Tomēr, kā uzskatami parādīja Jēgers, Aristofana (444.-438.387./380. g. p. m. ē.) daiḷrade ir veltīta tieši paideijaì. Arī pats Aristofans kādā savā lugā apgalvoja, ka cenšas būt noderīgs saviem skatītājiem un iemācìt vin,iem ko labu, ka „vieglais” žanrs viṇam nav šḳērslis, jo patiesību zina arī komēdija (Aristoph. Acharn., 500).

Principā šo pašu uzstādījumu var atrast arī klasiskā laikmeta prozā, vispirms vēsturnieku sacerējumos. Hērodots (ap 484.-425. g. p. m. ē.) rakstīja savu slaveno Vēsturi, lai neietu zudumā svarīgas ziṇas par hellēņu un barbaru darbiem, kas var būt pamācošas cilvēkiem (Hdt., I, 1). Tāpat arī Tūkidīds (ap 450.-399./396. g. p. m. è.) rakstīja Vēsturi, lai viṇa lasītāji varētu gūt kādu labumu (Thuc., I, 22, 4). Vēlāk, kad klasiskās 
drāmas spožums norietēja, paideijas karogu pacēla filozofiskā proza, kas mācìja cilvēkiem mākslu dzī̃ot.

Vārdu sakot, slavenie grieḳu dzejnieki, dramaturgi, vēsturnieki un filozofi savā daiļradē nodarbojās ar paideiju, cenzdamies iemācīt saviem laikabiedriem tās patiesības, kuras paši bija sapratuši. Visi viṇi vairāk vai mazāk, vienā vai citā veidā mācīja cilvēkus dzīvot, un visus viṇus vienoja kopīgs uzdevums - būt noderīgiem citiem cilvēkiem, visai sabiedrībai vai vismaz kādai tās daḷai. Visa mācība tika būvēta uz klasiskās krietnuma koncepcijas bāzes. Faktiski tāds arī toreiz bija radošās darbības galvenais uzdevums - mācìt cilvēkiem krietnumu, mācīt viņiem dzīvot, un tas nozīmē - realizēt paideiju.

Taču tieši klasiskajā laikmetā, kad grieḳu kultūra sasniedza savu spožāko virsotni, tika problematizēta pati paideija, tās būtība un uzdevumi. Jau arhaikas laikmetā bija dzejnieki, kuri ne tikai pašu daiḷradē bija atteikušies no vecās izpratnes par dzeju un tās uzdevumiem, bet arī atklāti kritizēja aristokrātisko vērtību sistēmu, kas bija tradicionālās paideijas pamats $^{10}$. Arī grieķu drāma vēl tikai neilgu laiku noturējās pie tradicionālās paideijas principiem, un jau Euripīds (480.-406. g. p. m. è.) - trešais no lielajiem traǵikịiem - savā daiḷradē no tiem atteicās. Viṇš vairs nemācỉja vecās vērtības un neaudzināja auditoriju, bet nodarbojās, kā mēs teiktu, ar „tīru mākslu”. Citi dzejnieki sekoja viṇa piemēram, kā rezultātā Sokrats (ap 469.-399. g. p. m. ē.) Platona Gorgijā pilnīgi diskvalificēja laikmetīgo dzeju no paideijas viedokḷa, pamatojot šo viedokli ar to, ka tā vairs nemāca tikumību, bet izdabā skatītājiem (Plat. Gorg., 501e-502d). Viṇa asā kritika un laikmetīgās dzejas noraidījums rāda, ka klasiskā paideijas koncepcija atradās dziḷas krīzes stāvoklī - tika apšaubīta pati vecās paideijas orientācija uz cilvēka audzināšanu. Bija sācies racionālais laikmets, kas sludināja jaunas pragmatiskas vērtības un piedāvāja jaunu izglītîbas koncepciju. Šìs jaunās koncepcijas nesēji bija sofisti, kuri uzṇēmās mācīt, bet ne vairs audzināt. Tātad audzināšana tika atrauta no izglītības jeb, citiem vārdiem, no izglītības tika izṇemts morālais aspekts. Līdz ar to grieḳu kultūras telpā ienāca diskusija par paideiju, tās mērḳiem un uzdevumiem. Vispirms radās teksti, kas problematizēja paideiju, un ḷoti drīz literatūrā sākās atklāta polemika par šiem jautājumiem.

Senākais teksts, kas tiešā veidā uzdod jautājumu par paideijas mērķiem un uzdevumiem, ir Aristofana komēdija Mākon,i, kas tika uzvesta 423. g. p. m. ē. Tajā parādīts jauns cilvēks, vārdā Feidipīds, kurš ir nonācis dzīves krustcelēs. Komēdijas kulminācijas ainā par viṇu iestājas 
cīṇā divas personificētas figūras - Taisnība un Netaisnība (Aristoph. Nubes, 709-1105). Viena piedāvā jauneklim iet tikumu un taisnības ceḷu, bet otra - nekrietnu dzīves baudīšanas ceḷu. Šis agons notiek brīdī, kad Feidipīds ir atnācis pie Sokrata ar mērḳi iemācīties netaisnas runas mākslu, lai atbrīvotu tēvu no kreditoru vajāšanām. Tātad jauneklis ir nonācis dzīves krustcelēs, un šajā brīdī tiek risināts jautājums par to, kam viņš sekos - tikumībai un krietnumam, ko iemieso Taisnība, vai jaunmodīgajām sofistu gudrībām, kas liek atteikties no morāles, solot par to pārtikušu un patīkamu dzīvi. Zīmīgi, ka Taisnība tiek sakauta un Feidipīds izvēlas netaisnu, bet jautru un tīkamu dzīvi. Acīmredzot tā Aristofans bija novērtējis situāciju savā pilsētā... Lai kā būtu, mēs varam apgalvot, ka tas ir pirmais teksts, kurā implicētā veidā tiek risināts jautājums par audzināšanu (izglìtîbu) un tās būtìbu. Faktiski grieḳu pasaulē tā ir pirmā diskusija par šo tēmu.

Lìdzīgi šis jautājums formulēts sofista Prodika (ap 465. - ap 395. g. p. m. ē.) slavenajā alegorijā par Hēraklu krustcelēs, ko atstāsta Ksenofonts (Xen. Memorab., II, 1, 21-34). Alegorijā vēstìts par brīdi jaunā Hērakla dzìvē, kad viņš, nobriedis patstāvīgai dzīvei, apdomā dzīves ceḷa izvēli. Pie viṇa ierodas divas sievietes - viena ir cēla un atturīgi skaista, pieklājīga un kautrīga, baltās drēbēs, bet otra - kliedzoši skaista, ar kārdinošām formām, caurspīdīgās drēbēs, plaši atvērtām acīm un bagātīgi izrotāta. Protams, pirmā ir Tikumība, bet otrā - Netikumība. Viena sieviete aicina Hēraklu iet grūtu, bet skaistu taisnības, krietnuma un slavas ceḷu saskaṇā ar dieviem un cilvēkiem (Ibid., 27-28), savukārt otrā sola vieglu un patīkamu, baudu un izpriecu pilnu dzīvi, ko var nodrošināt prasme gūt izdevīgumu visur, kur vien iespējams (Ibid., 23-25). Kā redzams, arī šajā stāstā notiek agons starp abām ētikas personifikācijām (Ibid., 29-31), tikai šoreiz uzvar Tikumība un gala vārds paliek viṇai (Ibid., 32-33). Principā tā ir līdzība par dzìves ceḷa izvēli, bet vienlaikus tajā alegoriskā veidā tiek risināts tas pats jautājums par paideijas būtību. Šeit parādīta dilemma, kas bija aktuāla tā laika jauniešiem: mācìties krietnumu vai to, kā gūt praktisku labumu, pat ja tas tiek sasniegts nekrietnā ceḷā? Principā tas ir jautājums par izglìtības mērḳiem un virzienu, jo visiem, uz kuriem attiecās paideija, bija jāizvēlas - mācìt/ mācīties krietnumu vai izdevīgumu?

Vēlreiz šis jautājums aktualizēts Sofokla (485.-405. g. p. m. è.) lugā Filoktēts, kas tika uzvesta Atēnās 409. g. p. m. ē. Šajā darbā izvēles priekšā nonāk Ahilleja atvase Neoptolems, vēl nepieredzējis jaunietis, kurš 
nonācis liktenīgas izvēles priekšā: viṇam ir jāizšḳiras starp praktisku nepieciešamību, kas saistīta ar negodu, un tīru, neaptraipītu krietnumu. Jauneklim kopā ar Odiseju tiek uzticēts iegūt Filoktēta loku, bez kura ahaji nevar ieṇemt Troju. Filoktēts jau deviņus gadus vientulībā dzìvo uz neapdzīvotas salas, kur viņš, ahaju pamests, cieš šausmīgas sāpes no savas brūces. Viṇš ir nāvīgi apvainojies uz visiem ahajiem, un pierunāt viṇu uz izlīgumu nav nekādas iespējas. Tādẹl Odisejs piedāvā Neoptolemam viltīgu plānu: viņam ir jāaiziet pie Filoktēta un jāmelo, ka viņš bēg no ahajiem viṇu netaisnības dẹl (tādā veidā viṇam ar viltu ir jānopelna vientuḷnieka uzticība), izdevīgā brīdī jānozog loks un jādodas uz kug̣i, kur viṇu gaidīs Odisejs. Sākumā Neoptolems pretojas, teikdams, ka nav spējīgs uz nekrietnu rīcību, bet beigās viņš padodas Odiseja spiedienam. Pieredzes bagātais viltnieks Odisejs uzstājas kā îsts sofists, lietojot visus iespējamos argumentus: viņš sola jauneklim lielu slavu izdošanās gadījumā, bet vienlaikus arī glaimo un draud ar visu ahaju naidu un vajāšanām, ja viņš atteiksies. Stiprākais arguments ir nepieciešamība glābt ahaju karaspēku, jo bez Filoktēta loka visi viṇu pūliṇi un upuri pie Trojas mūriem būtu veltīgi.

Tātad Neoptolemam bija jāizvēlas starp racionāli pamatotu nepieciešamību, kas atstumj malā morāli, un pašu morāli, kas neatkarīgi no apstākḷiem liedz krietnam cilvēkam rīkoties nekrietni. Objektīva nepieciešamība sākumā n,em virsroku, un Ahilleja dēls rīkojas pēc Odiseja plāna, taču sirdsapziņas pārmetumi neḷauj viņam novest lietu līdz galam, viņš atzīstas Filoktētam un atdod nozagto loku viņam atpakal,. Neoptolems izlemj palikt uz krietnuma ceḷa un ir gatavs nest atbildību par savu izvēli. Pateicoties šādam jaunekḷa lēmumam, situācija kopumā nonāk strupceḷā, jo bez Filoktēta loka nevar piepildīties Trojas liktenis, kas jau iepriekš ir augstāko spēku noteikts. Tādēl atbilstoši formulai deus ex machina no debesīm nolaižas Hērakls un paziṇo visiem dievu gribu: Filoktētam ir jāatsakās no savām dusmām un jādodas uz ahaju nometni, kur viṇš taps dziedināts, nogalinās Parīdu un kopā ar Neoptolemu veiks lielus varoṇdarbus, līdz beidzot Troja tiks ienemta. Šāds fināls liecina, ka Sofokls nav redzējis konflikta atrisinājumu parastiem cilvēciskiem līdzekḷiem.

Dabiski, ka lugas gaitā Neoptolems nonāk konfliktā ar Odiseju, kurš visiem spēkiem cenšas nepiel̦aut viṇa izvēli par labu krietnumam jeb, kā to definē mūsdienu pētnieki, atgriešanos pie savas patiesās dabas ${ }^{11}$. Šajā konfliktā viṇi abi iemieso divus pretējus kultūras principus jeb divas pretējas paideijas. Formāli spriežot, lugā tiek risināts praktiskas dabas 
jautājums, t. i., konkrēta jaunieša izvēle konkrētā situācijā. Taču pēc būtības tas ir principiāls jautājums par paideiju. Kā atzīmē kritiḳi, lugas sākumā, kad Odisejs pamāca Neoptolemu, viņi abi atrodas skolotāja un skolnieka situācijāa ${ }^{12}$. Vienlaikus tā ir kārdināšanas situācija, kurā jauns un nepieredzējis varonis tiek kārdināts un neiztur pārbaudījumu ${ }^{13}$. Tiek pārbaudīta jaunieša patiesā paideija, pakḷaujot viņu spiedienam no neīstas, morāli nosodāmas paideijas puses, kas krietnumu upurē par labu lietderīgumam. Faktiski Sofokls šajā lugā parāda divu vērtību sistēmu konfrontāciju - tradicionālo, kas centrā liek aristokrātiska krietnuma kategoriju, un moderno, demokrātisko, kas visas lietas pakārto praktiskam labumam $^{14}$. Šajos laikos cilvēkiem ir jāizvēlas starp abām šīm pozīijāàm, un no viṇu lēmuma ir atkarīga arī paideijas izvēle. Tagad ir jāizvēlas paideija - tradicionālā vai modernā, ar morāli vai bez tās, izglītība kopā ar tikumisko audzināšanu vai bez tās...

Pirmā atklātā diskusija par abām paideijām parādīta Aristofana komēdijā Vardes, kas tika uzvesta 405. g. p. m. è. Šajā lugā Dionīss nokāpj pazemes valstībā, lai izvēlētos kādu no lielajiem dramaturgiem, kuram būtu jāatgriežas dzīvības gaismā, jo augšā, t. i., virszemēe labu dramaturgu vairs nav. Komēdijas kulmināciju veido Aishila un Euripīda vārdiskais agons pazemes valstībā. Šìs diskusijas laikā Aishils uzdod Euripīdam vissvarīgāko jautājumu: par ko tiek cildināti dzejnieki? Un saṇem šādu atbildi:

Tik par saprātu, protams, un padomu gudru! Tik

Tāpēc mēs dzimtenē savā

L,audis labākus audzināt varam. (Aristoph. Ranae, 1009-1010; A. Ģiezena tulk.)

Uz šo vārdu pamata Aishils pārmet Euripīdam, ka viņš nav sekojis šim uzdevumam un ar savu dzeju esot pārvērtis ḷaudis par neliešiem ìstiem. Dionīss tūdal, iesaucas, ka par to Euripīds ir pelnījis nāvessodu (Ibid., 1011-1014). Turpinot polemiku, Aishils apvaino Euripīdu cilvēku samaitāšanā (Ibid., 1069-1073) un vēlreiz formulē dzejnieka misijas būtību: kā skolotājs mēdz vadìt un audzināt zēnus, tā jaunāko paaudzi-dzejnieks. Visu cēlu un daiḷ pauž dzejnieks (Ibid., 1055sqq; A. Ģiezena tulk.). Var viegli ieraudzīt, ka šajos vārdos ir ḷoti precīzi formulēti tradicionālie priekšstati par dzejas mākslas būtību: dzejnieks tiek pasludināts par skolotāju, kura uzdevums ir audzināt tautai krietnumu. Kā jau teikts, tas ir attiecināms uz jebkuru grieḳu mākslu, bet īpaši uz vārda mākslu, un 
visvairāk tieši dzeju. Tā diskusija par mākslas uzdevumiem pārvēršas diskusijā par paideiju. Ar Aishila vārdiem Aristofans izteica tradicionālās paideijas pašu būtību.

Tomēr pats publiskās polemikas fakts liecina par to, ka šajā laikā grieḳu sabiedrībā tradicionālā paideijas izpratne tiek noliegta un pat apkarota. Lūzums, kas bija noticis grieķu kultūrā klasikas laikmetā, noveda pie tā, ka daudzi mākslinieki bija atteikušies no šì principa, un Euripīds bija to skaitā. Tieši tādēl konservatīvi noskaņotais Aristofans polemizē ar Euripīdu gan šajā lugā, gan uzbrūk viņam arī citās savās komēdijās. Taču saprotams, ka Euripīds nebija pats radījis šo jauno izpratni par mākslu un paideiju, viņš bija tikai jauno uzskatu sekotājs. Jaunās ideologijas patiesie autori un sludinātāji bija sofisti. Viņi bija īsti vārda meistari, kas ceḷoja pa visu grieķu pasauli, pārdodami savu gudrību par lielu naudu. Viņi bija rētorikas skolotāji, tātad profesionāli nodarbojās ar paideiju, tikai viṇu paideija radikāli atšķ̄iās no tradicionālās. Konfrontācija starp abām ideologijām bija neizbēgama, un liktenis bija sarūpējis sofistiem divus geniālus oponentus, tradicionālo vērtību aizstāvjus - Sokratu un Platonu (428./427.-348./347. g. p. m. ē.). Vinuu polemika ar sofistiem maksimāli skaidri un izvērsti atklāja abu paideijas koncepciju principiālās atškirīìbas.

Protams, situācija ar avotiem ir tāda, ka mums ir grūti nodalīt Sokratu no Platona, un šodien katram, kas raksta par Sokratu, ir jāformulē sava pozīcija šajā jautājumā ${ }^{15}$. Neielaižoties garās debatēs par šo tēmu, teikšu, ka, manuprāt, Sokrats ir atrodams Ksenofonta (444.-356. g. p. m. ē.) Atminnās ${ }^{16}$ un Platona agrīnajos jeb t. s. sokratiskajos dialogos ${ }^{17}$. Nav šaubu, ka Sokrats polemizēja ar sofistiem mutiski sarunu laikā, bet Platons darīja to pašu savos sacerējumos. Bet pat neatkarīgi no tā, kā mēs risinām jautājumu par Sokrata un Platona identitāti, šajā gadījumā svarīgākais fakts ir tas, ka jautājumā par paideiju viṇi pauda vienotu konservatīvu pozīciju. Tātad Sokrata diskusija ar sofistiem, kā to apraksta Platons un Ksenofonts ${ }^{18}$, atspoguḷo reālu vērtību sadursmi.

Pirmais jautājums, kas tika diskutēts starp Sokratu un sofistiem paideijas sakarā, ir jautājums par studiju maksu. Kā zināms, Sokrats neṇēma naudu par savām mācībām, turpretī sofistiem tas bija peḷnas avots. Ksenofonta Atmin̄ās ir dialogs, kurā slavens sofists Antifonts (5. gs. p. m. è., otrā puse) uzbrūk Sokratam par to, ka viṇš neṇem maksu par savām nodarbībām. Faktiski tās ir divas sarunas un divas argumentācijas: pirmajā reizē Antifonts pārmet Sokratam nožēlojami 
trūcīgo dzīvesveidu (Xen. Memor., I, 6, 3), bet otrajā reizē viņš jau lieto smalku sofismu un uzstājas ar šādu apgalvojumu: tā kā visām lietām ir cena, bet Sokrats neṇem naudu par savām mācībām, tas nozīmē, ka viṇš pats neuzskata tās par kaut cik vērtām, tātad tās tiešām nav neko vērtas (Ibid., 11-12). Uz pirmo tēzi Sokrats atbild, ka, neṇemdams naudu no mācekḷiem, viņš saglabā savu brīvību un nav spiests runāt, ar ko nevēlas, turpretī sofistam ir jāatstrādā sava nauda (Ibid., I, 6, 4-5). Tam seko arī izvērsts teksts par savaldības un pieticības tikumiem (Ibid., I, 6, 6-10). Savukārt otro tēzi viņš atspēko, pret sofismu lietojot vēl smalkāku sofismu: vispirms viṇš pielīdzina zināšanas skaistumam, bet pēc tam salīdzina tirgošanos ar zināšanām ar tirgošanos ar skaistumu, t. i., miesu: ja kāds savu skaistumu kuram katram pārdod par naudu, to sauc par prostitūtu (лó $\rho v \eta) .$. Tāpat tas ir ar zināšanām: cilvēkus, kas tās kuram katram pārdod par naudu, sauc par sofistiem (Ibid., I, 6, 13; A.. Feldhūna tulk.). Pats par sevi Sokrats norāda, ka viṇš gūst baudījumu nevis no miesīgām izpriecām, bet no apziṇas, ka pats kḷūst labāks un dara labākus savus draugus (Ibid., I, 6, 9). Šeit ir jāatzīst, ka Sokrats trāpīja tieši desmitniekā, jo tradicionālo vērtību sistēmā vēl vairāk pazemot sofistiku nebija iespējams ${ }^{19}$. Lai to saprastu, ir jāatceras, ka grieḳu kultūrā ne tikai prostitūcija tika kvalificēta kā zema nodarbe, bet arī jebkurš algots darbs tika uzskatīts par apkaunojošu lietu un nebrīves pazīmi ${ }^{20}$.

Ir labi redzams, ka šajā īsajā diskusijā par studiju maksu saduras ne tikai divas dažādas attieksmes pret paideiju, bet arī divas pretējas vērtību sistēmas. Sokrats pārstāv tradicionālo grieḳu kultūras pozīciju, un viṇa pasaules uzskatā pirmo vietu ieṇem morāles kategorijas, taču Antifonta vērtību sistēma ir visai moderna, un tajā par vērtīgu tiek atzìts tikai tas, kas var tikt izmērīts ar naudu un pārdots ${ }^{21}$. Pie tam šì vērtību sistēma piemita ne tikai viņam, bet arī citiem sofistiem, kuri profesionāli tirgojās ar savām zināšanām. Par to var pārliecināties, lasot Platona dialogus.

Piemēram, Hipijā Lielākajā slavens sofists lielās ar to, ka viṇš pelna vairāk par citiem, ieskaitot dižāko no sofistiem - pašu Protagoru (Plat. Hipp. Maior, 282e). Turpat tiek pastāstīts, ka arī citi vareni sofisti, tādi kā Gorgijs (483.-380. g. p. m. ē.) un Prodiks, pelna lielu naudu ar savu gudrību, pat lielāku nekā citu arodu meistari (Ibid., 282b-d). Sokrats ironiski pajoko par to un secina, ka atbilstoši daudzu cilvēku viedoklim par gudru tiek atzìts vienīgi tas, kurš ir gudrs pats priekš sevis, no kā izriet, ka gudrs ir tas, kurš pelna daudz naudas (Ibid., 283b). Tādā veidā viņš īsi noformulē sofistu darbības būtību, un Hipijs viṇam klusējot piekrīt. 
Dialoga beigās, kad Sokrata spriedumi par to, kas ir skaisti un kas nav, Hipiju ir pamatīgi sakaitinājuši, viņš kodolīgi noformulē sofistikas patieso credo: par skaisto viņš uzskata māku uzstāties ar labu, skaistu runu, pārliecināt klausītājus un aiziet prom ar balvu, turklāt ne niecīgu, bet vislielāko (Ibid., 304b). Tādā pašā stilā arī Gorgijs skaidro Sokratam rētorikas mākslas uzdevumus: viņaprāt, šì māksla ir vajadzīga, lai pārliecinātu cilvēkus sapulcēs un tiesās, bet pārliecinot - valdīt pār viṇiem un pelnīt naudu (Plat. Gorg., 452e). Nauda ir kḷuvusi par daiḷrunības mērḳi tādēl, ka tā stāv pirmajā vietā sofistu vērtību sistēmā. Tādēḷ uz jautājumu, kas ir skaisti, Hipijs atbild, ka vispirms tas ir būt bagātam, tad veselam utt. (Plat. Hipp. Maior, 291d). Savukārt dialogā Menons Gorgija skolnieks, definēdams labumu, atzīst, ka labums ir sakrāt zeltu un sudrabu, iegūt godu un varu valstī (Plat. Meno., 78c). Nav brīnums, ka Sofistā Platona Sokrats definē sofistiku kā bagātu jauniešu medības, kā tirgošanos ar zināšanām un vispār kā naudas peln̄̄šanas veidu ar vārdiem (Plat. Soph., 223b, 224d, 226a).

Kā zināms, sofisti darbojās pilnīgā saskaṇā ar šiem principiem: viṇi ceḷoja pa visu Helladu, gan pārdodami savas zināšanas un prasmes, gan uzstājoties ar runām, gan mācot. Mūsu rīcībā ir fakti, kas liecina par viņu panākumiem. Tā, piemēram, ir zināms, ka Gorgijs uzcēla sev Delfos zelta statuju (Paus., VI, 17, 7; Athen., XI, 505d; Cic. De orat., III, 32, 129), kas, bez šaubām, ir lielas bagātības rādītājs. Vēl jo vairāk Plīnijs apgalvo, ka Gorgijs bija pirmais, kas pats sev uzcēla zelta statuju svētnīcā (Plin. Hist. Nat., XXXIII, 83). Šajā gadījumā tā ir arī liecība viṇa

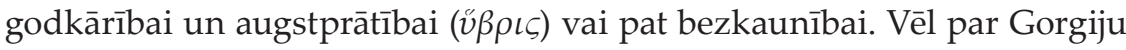
un Hipiju stāstīts, ka viṇi mēdza uzstāties purpura mantijās (Ael. Hist. Var., XII, 32), kas arī ir lielas greznības rādītājs. Katrā ziṇā tas viss saskan ar to, ko mēs redzam Platona dialogos ${ }^{22}$. Tādēḷ nav brīnums, ka ne tikai Antifonts, bet arī citi sofisti pārmeta Sokratam viṇa nabadzību. Tā, piemēram, Platona dialogā Gorgijs viṇi cildina naudas un varas spēku un iesaka Sokratam pamest savas tukšās runas un ņemt piemēru no vareniem, slaveniem un bagātiem (Plat. Gorg., 483a ff, 486c). Sokrats atbildēja viṇiem savā stilā - ar vārdiem par atturību, par to, ka laime ir nevis naudā, bet taisnībā utt. (Ibid., 470e, 491e).

Tātad sofistu darbības mērḳis ir nevis mācīt un audzināt, bet labi nopelnīt. Viṇi lieto savas prasmes („gudrību”) un māca tās citiem tikai naudas dēḷ. Viṇu valodā tas nozīmē būt gudram pašam priekš sevis ${ }^{23}$. Viṇu paideija ir vērsta nevis uz skolnieka labumu, bet uz paša skolotāja 
pašlabumu, t. i., peḷnu. Tas uzrāda asu kontrastu ar visu iepriekšējo paideijas tradīciju, kas līdz šim veidoja grieḳu kultūru, un saskaņā ar to katrs radošs cilvēks tiecās būt "gudrs" vispirms citiem cilvēkiem, proti, centās savā daiḷlradē audzināt citus vai vismaz būt citiem noderīgs. Tā vietā sofisti par gudrības mērauklu nolika naudu - tas pilnībā saskan ar mūsdienu populāro teicienu: If you are so clever, show me your money. Tātad sofisti bija ḷoti moderni, un tas ḷauj saprast mūsu laikmeta simpātijas pret viṇiem. Starp citu, šajā kontekstā tradicionālais viedoklis par sofistiem kā par apgaismības un progresa nesējiem ${ }^{24}$ škiet nekorekts. N̦emot vērā viṇu patiesos mērḳus, pareizāk būtu saukt viṇus par postmodernistiem. Galu galā arī mūsdienās arvien biežāk redzam, ka par augstskolas uzdevumu tiek uzskatīta naudas pelnīšana...

Pats par sevi saprotams, ka, pateicoties savam principiālajam uzstādījumam par naudas peln̄̄̌sanu, sofisti izmeta no klasiskās grieḳu paideijas tās galveno sastāvdaḷu - audzināšanu. Tas ir dabiski, jo audzināšanas mērķis ir tikums, bet, ja tikuma vietu ieņem nauda, tad nevar būt arī nekādas audzināšanas, ir iespējama tikai profesionāla apmācība. Pie tam tā arī var būt ḷoti dažāda - ar morāli vai bez tās. Sofisti par lielu naudu mācīja iemaṇas nopelnīt naudu ar rētorikas palīdzību neatkarīgi no morāles apsvērumiem. Citiem vārdiem, viṇi gatavoja tādus pašus sofistus. Tāda bija viṇu jaunā izpratne par paideiju. Kā redzams, tās pamatā ir pilnīga morālā brīvība ${ }^{25}$. Sofistam visi līdzekḷi ir labi, lai panāktu savu mērķi. Gorgijā to skaidri pasaka sofists Pols, kurš Sokratam apgalvo, ka veiksmīgi cilvēki ir apskaušanas vērti neatkarīgi no tā, vai viṇu rīcība ir bijusi taisnīga vai nē (Plat. Gorg., 469e; 471a-d etc.). Pats Gorgijs uzskata, ka oratoram pat nav jāzina lietas būtība, par kuru viņš runā, svarīgākais ir pārliecināt klausītājus par to, kas viṇam ir vajadzīgs. Jebkurā strīdā ar jebkuras nozares speciālistu orators būšot uzvarētājs, jo viṇš prot pārliecināt, un tauta izvēlēsies nevis to ārstu, kurš ir lietpratējs, bet to, kurš pārzina vārda mākslu un var pārliecināt, ka viņš ir labākais. Dabiski, ka sekas sofistu neinterese $\bar{e}^{26}$, jo viṇa mērķis ir tikai nopelnīt. Turklāt tālāk tiek apgalvots, ka rētorikas skolotājs ir brīvs no atbildības par to, kā viṇa skolnieki izmantos viņa mākslu (Plat. Gorg., 456b-457b; 459b-c).

Citi avoti apstiprina šo Platona sniegto sofistu raksturojumu. Piemēram, par Protagoru (ap. 490. - ap 420. g. p. m. ē.) tika stāstīts, ka viņš pelna lielu naudu, mācot, kā ar vārda mākslas palīdzību padarīt vāju argumentu par stipru (Diog. Laert., IX, 51; Aul. Gell., V, 3, 7)²7. Saprotams, ka šai mācībai nebija nekas kopīgs ar patiesību. Vārdu sakot, 
sofisti paši lietoja savu daiḷrunības mākslu bez morāles bremzēm un mācìja to darīt arī saviem skolniekiem. Šeit nav un nevar būt vieta morālei un audzināšanai, tātad paideijai tās klasiskajā izpratnē.

Kā jau minēts, pret sofistiem nostājās Sokrats un Platons - divi tradicionālās paideijas aizstāvji. Viṇi abi pauž pārliecību, ka radošajam darbam ir jābūt brīvam no alkatības un vērstam uz to, lai nestu labumu cilvēkiem. Šì orientācija uz labuma nešanu cilvēkiem piešķir jebkurai mākslai audzināšanas funkciju, tātad padara to par paideiju. Balstoties uz šiem principiem, Platona dialogā Protagors tiek izvērsta diskusija par izglītības jēgu. Šeit jaunietim, kurš grasās studēt pie Protagora, tiek uzdots jautājums, ko viņš grib iemācīties no dižā sofista. Noskaidrojas, ka jaunietim pat nav priekšstata, par kāda veida gudrību viṇš grasās maksāt naudu (Plat. Protag., 312a-e). Tad Sokrats parāda, ka viņa dvēselei draud lielas briesmas, ja viņš nespēj pateikt, vai jaunās zināšanas nāks tai par labu vai par l̦aunu, un ka to nezina arī paši sofisti, kuri braukā pa pasauli un piedāvā savas zināšanas pa labi un pa kreisi kā pārtikas tirgotāji, kuri tikai slavē savu preci, bet izvairās no jautājuma par tās lietderību (Ibid., 313a-314a). Tādā veidā Sokrats liek akcentu uz paideijas tikumisko nozīmi un padara krietnuma kategoriju par galveno vērtēšanas kritēriju. Tas ir viṇa klajš izaicinājums sofistikai kā tādai.

Šì tēma tiek attīstīta dialogā Gorgijs, kurā ḷoti spilgti parādīts Sokrata konflikts ar sofistiem, uzdodot jautājumu par rētorikas jēgu. Pēc tam, kad Gorgijs prezentē sofistu vērtību sistēmu, atklādams savus mērķus pelnīt un valdīt (Plat. Gorg., 452e; līdzīgi: 454b-455a; 455b-459c), Sokrats pretnostata tai savu, morālē balstīto vērtību sistēmu. Viņš apgalvo, ka visas mākslas ir jāvērtē pēc tā, vai tās nāk par labu vai par ḷaunu cilvē-

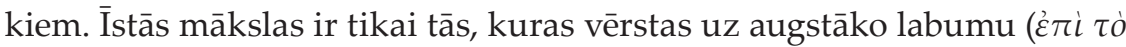
$\beta \varepsilon ́ \lambda \tau \iota \sigma \tau o v$ - Ibid., 503d), atšķirībā no dažādām zemākas dabas mākām, kas vērstas uz baudu un spēj tikai izdabāt un kaitēt (Ibid., 459b-465d). Sofistu runas māksla ir slikta tieši tādēḷ, ka, izdabājot cilvēkiem, tā veicina viṇu tikumisko degradāciju, tātad to vispār nedrīkst saukt par mākslu, bet labākajā gadījumā par kādu māku, līdzīgu pavāra mākai (Ibid., 459b-466b, 502c-503b). Lìdz ar to par mākslu tiek pasludinātas tikai tādas mākas, kas dara cilvēkus labākus, proti, tādas, kas audzina un atbilst īstās paideijas sūtībai. Tiek secināts, ka jebkuras mākslas uzdevums ir audzināt tikumību, tātad darìt cilvēkus labākus (Ibid., 513e). No vienas puses, tas ir skolotāja uzdevums, bet, no otras puses, paša jaunā cilvēka, kurš vēlas mācīties, uzdevums. 
Tādā veidā jautājums par intelektuālas darbības mērkiem pakāpeniski pāraug jautājumā par to, kā vispār dzīvot (Ibid., 500b) ${ }^{28}$. Dialoga kontekstā tas izskan kā jautājums par dzīves jēgu kā tādu ${ }^{29}$. Pie tam runa šeit ir ne tikai par izvēli starp aktīvu dzīvi un filozofisku dzīvi ${ }^{30}$, bet arī par galveno dzīves orientieru izvēli. Rezultātā izvēle starp sofistisko rētoriku un patieso rētoriku Sokratam un Platonam nozīmē izvēli starp netikuma un tikuma ceḷu. Vienlaikus tā ir izvēle starp patieso paideiju un neīsto. Vārdu sakot, tā ir tā pati izvēles situācija, kuru aprakstīja Aristofans Mākon,os, Sofokls Filoktētā un Prodiks savā līdzībā par Hēraklu. Nav šaubu, ka tikumiskā pagrimuma laikos, ko piedzīvoja toreizējās Atēnas, tas bija ārkārtīgi aktuāls jautājums.

Pats par sevi Sokrats saka, ka viňš vienmēr vada savas sarunas

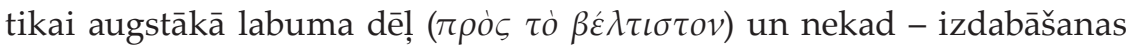
vai baudas dēḷ kā sofisti (Plat. Gorg., 521e). Būtībā to pašu, tikai citiem vārdiem Sokrats saka Ksenofonta Atminnās. Tur, atbildējis uz Antifonta pārmetumu par naudas neņemšanu un nosaucis sofistu mākslu par prostitūciju, viņš turpina: bet par tādu, kas citam, kurā saskata labas dotības, māca ko labu, ko zina pats, un iegūst viņu par savu draugu, spriežam, ka viņš rīkojas tā, kā pienākas cildenam un krietnam vìram (Xen. Memor., I, 6, 13; $\bar{A}$. Feldhūna tulk.). Kā redzams, šajos vārdos Sokrats noformulē īstās paideijas uzdevumu - mācìt citiem to labo, ko zina pats. Tā rīkojas arī viņš pats, mīlēdams savus draugus un cenzdamies darìt visu, lai veicinātu vinu tikumisko attīstību (Ibid., I, 6, 14).

Tātad Sokrats pasludina sevi par skolotāju, kurš, mācot citiem tikumu, kalpo paideijas augstajam ideālam. Acīmredzot, reaǵēdams uz sava laika sabiedriskajām realitātēm, ideoloǵiskās cīnas apstākḷos ar sofistiem viņš savā paideijā uzsver tieši tikumības audzināšanu, uzskatot to par pašu galveno visā izglītībā. Tā izpaudās Sokrata dzìves jēga un misija: kḷūt labākam pašam un censties darīt labākus arī citus sev apkārt. Ja sofisti ir gudri „paši priekš sevis”, tad Sokrata gudrība kalpo citiem. Tas nozīmē, ka viņš veltīja sevi audzināšanai, t. i., tikumības mācīšanai ${ }^{31}$. Platona Apoloǵijā viņš visu savu dzīvi raksturo kā nodarbošanos ar paideiju, kā kalpošanu cilvēkiem un savai valstij (Plat. Apol., 29d-30b, 36b-d; sk. arī: Gorg., 526d) ${ }^{32}$. Viňš ir pārliecināts, ka darīt to viņam ir likusi dievība un ka savās sarunās ar cilvēkiem viņš izpilda dievišķu misiju. Tātad viṇa izpratnē paideija ir kalpošana cilvēkiem, bet kalpošana, kā zināms, ir upurēšanās, nevis pelnīšana. Taču upurēšanās var prasīt arī paša dzīvi, un uz Sokratu tas attiecas pilnā mērā - viņš bija uzticīgs 
savai misijai līdz nāves stundai un izvēlējās labāk mirt nekā atteikties no tās... Pēc viṇa nāves diskusijas par paideiju nemanāmi apklusa, jo divas izšķirošās pozīcijas tika definētas reiz un uz visiem laikiem, un turpmāk katram atlika tikai izvēlēties savu paideijas veidu un dzives ceḷu atbilstoši savai vērtību sistēmai...

Rezumējot var secināt, ka grieḳu priekšstati par paideiju laika gaitā piedzīvoja nozīmīgu evolūciju, kā rezultātā sākotnējo vienprātību nomainija divu radikāli pretēju viedokḷu polemika. Vispirms dramaturgi, atbildot uz laika prasībām, uz skatuves uzdeva jautājumu par paideijas jēgu, bet vēlāk sofistu - Sokrata/Platona diskusija par divām paideijas koncepcijām pārvērtās īstā konfrontācijā. Sofistu koncepcija balstijās uz viṇu jauno vērtību sistēmu, kurā centrālo vietu ieņēma nauda un praktiskie panākumi, bet ne morāle. Viṇu paideija kalpoja paša labumam un panākumu gūšanai. Iepretī tam Sokrats un Platons attīstīja tradicionālo izpratni par paideiju, interpretējot to galvenokārt kā tikumisko audzināšanu un kalpošanu cilvēkiem. Šì pozīcija balstās uz religisko vērtību sistēmu, lai arī viṇu abu reliǵiozitāte būtiski atšḳīās no grieḳu tradicionālās dievbijības. Tātad Sokrata un sofistu polemika savā būtībā bija divu pasaules uzskatu konfrontācija. Tas nozīmē, ka lūzums bija noticis ne tikai paideijas izpratnē, bet kultūrā kopumā. Mainījās ne tikai dzīves apstākḷi, bet fundamentālas vērtības. Vecos ideālus nomainīja jauni. Sofisti gāja jaunā laikmeta avangardā, likdami teorētisko pamatu jauno vērtību pasaulei. Viṇu darbība iezīmēja kultūras lūzumu, kuru mēs varētu nosaukt par savdabīgu "grieķu modernizāciju”. Šî „,modernizācija” skāra visas dzìves jomas - politiku, ekonomiku, sociālo sfēru, kultūru. Viena no tās izpausmēm bija arī jaunā izpratne par paideiju un tās jēgu.

Taču vecā pasaule un vecā vērtību sistēma nepadevās un ieguva jaunu interpretāciju un jaunu dzìvi Sokrata idejās un Platona darbos. Rezultātā hellēṇu diskusijas par paideiju atklāj mums ne tikai priekšstatu evolūciju par izglītību un audzināšanu, bet arī paver iespēju dziḷāk saprast tā kultūras lūzuma jēgu, kas bija noticis klasiskā laikmeta Helladā. Kopš tā laika un līdz šai dienai katram, kas nodarbojas ar radošu darbu, ir jāatbild sev pašam uz jautājumu: kam kalpo viņa daiḷrade - viṇam pašam vai citiem cilvēkiem, t. i, paideijai? Un, protams, tagad, kad izglìtības sistēma stāv kārtējo reformu priekšā, mums kā nekad ir aktuāls seno grieķu diskutētais jautājums par izglītības mērķiem - vai tai ir jākalpo paideijas cēlajiem ideāliem, vai arī tai ir jākḷūst par naudas peln̄̄šanas instrumentu? 


\section{ATSAUCES}

1 Jaeger 1934. Turpmāk šis darbs tiek citēts no krievu tulkojuma: Йегер 1997-2001.

2 Par cieṇu, ko baudīja dzejnieki, liecina šāda epizode Homēra eposā: kad Odisejs izrēḳinājās ar preciniekiem, viņš atstāja dzīvu vienīgi dzejnieku Fēmiju un ziṇnesi Medontu, par kuru bija lūdzis Tēlemahs (Od., XXII, 330-377).

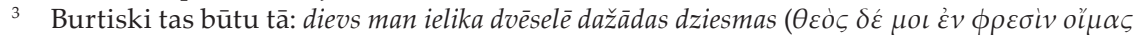
$\pi \alpha v \tau o i \alpha \varsigma$ غ̇vé $\phi v \sigma \varepsilon v)$.

4 Йегер 2001, 41-56.

5 Seybold, Ungern-Sternberg 1993, 215-239.

6 Sk.: Jaeger 1970, 7-31; Manuwald 1989, $12 \mathrm{ff}$.

7 Tādā veidā tika radītas asociācijas ar mūsdienām, kas aktualizēja lugas problemātiku skatītāja acīs - sīkāk par to sk.: Easterling 1997, 22-25. Turklāt bieži vien traǵēdiju tekstā tika iepītas norādes uz tā laika politiskajām aktualitātēm: Podlecki 1996. Sk. arī: Ehrenberg 1954, 12-24 etc.

8 Sīkāk sk.: Йегер 2001, 127-154.

9 Ibid., 196-210.

10 Sk.: Donlan 1973, 145-154.

11 Egermann 1979, 6f; Яpxo 2005, 208.

12 Roisman 2005, 92f; sal.: Melchinger 1979, 153.

13 Ibid., $153 f$.

14 Protams, sociālais konteksts šeit ir acīmredzams: Neoptolems neapšaubāmi iemieso senu aristokrātisko pozīciju, taču Odisejs pārstāv jauna tipa racionālo pragmatismu jeb tā saucamo demokrātisko skatpunktu (democratic viewpoint) - sk.: Knox 1964, 122.

15 Kā trāpīgi atzīmējis Jēgers, problēmas sāls ir noteikt, no kuras vietas tekstā ir vairāk Platona nekā Sokrata: Иегер 1997, 67. Sk. arī: Chroust 1957, 1ff; Guardini 1987, 12f, 80-99; Stone 1990, 17; Martens 1992, 13f; Böhme 1992, 17; Navia 1993; Wallach 2001, 86ff etc. Tā kā avoti sniedz mums neskaidru un brīžiem pat pretrunīgu ainu, netrūkst autoru, kuri cenšas ar vienu cirtienu pārcirst Gordija mezglu un visu literatūru par Sokratu pasludina par literāru fikciju, kas ḷaujot mums runāt tikai par Sokrata tēlu, nevis par viṇu pašu: Martens 1992, 13; Böhme 1992, 25f, 31; Gigon 1947, 14; Dupréel 1922; Fischer 1969; Waterfield 2009, 10ff; Рассел 2002, 107 etc. Šāda hiperkritiska pieeja man liekas nepieṇemama, jo tā balstās nevis uz stingriem pierādījumiem, bet autoru brīvu interpretāciju, kuras pamatā ir ",avotu vainas prezumpcija”.

16 Attieksme pret Ksenofonta liecībām parasti ir kritiska - sīkāk sk.: Jöel 1893-1901; Maier 1913, 20-77; Pleger, W. Sokrates. Der Beginn des philosophischen Dialogs. Hamburg, 1998, 80ff, 99; Chroust 1957, 2ff; Mosse 1999, 65; Böhme 1992, 29f; Colaiaco 2001, 2f, 17-21 etc.; Йегер 1997, 54. Es piekrītu S. Sobolevksa viedoklim, kurš uzskatīja, ka Ksenofonta Atminas ir vērtīgs avots par Sokratu: Соболевский 1993, 285-291. Galvenais arguments par labu Ksenofontam ir tas, ka viṇam nebija savas filozofijas, kuru viņš varētu ielikt Sokrata mutē. Turklāt viṇa dialogi ir īsi un vairāk izskatās pēc sarunu pierakstiem nekā garie un stipri literarizētie Platona dialogi. Fakts, ka Ksenofonts centās attaisnot savu skolotāju, vēl nenozīmē, ka viṇš būtu melojis. Viņš rakstīja par lietām, kas bija labi pazīstamas plašai publikai, un varēja tikai izpušḳot vai interpretēt, nevis melot. Pie tam, kā zināms, lai attaisnotu godīgu cilvēku no meliem, ir vajadzīga tikai patiesība, nevis citi meli.

17 Sk.: Burnet 1914; Maier 1913, 103f, 147f, 156; Pohlenz 1913; Guthrie 1971, 29-35; Pleger 1998, 96f; Benson 2000; Йегер 1997, 108 слл. Etc., etc., etc.

18 Protams, skeptiski noskaņoti pētnieki akcentē pretrunas Platona un Ksenofonta liecībās: Dorion 2006, 93-109. Taču jāṇem vērā divas lietas: pirmkārt, abos tekstos ir vairāk sakritību nekā pretrunu, otrkārt, tie paši fakti atkarībā no pētnieka pozīcijas var 
tikt izskaidroti pavisam citā, pat pretējā veidā, jo visas interpretācijas ir atkarīgas tikai no paša zinātnieka subjektivitātes.

19 Maier 1913, 254.

20 Jādomā, tas ir tādēl, ka grieḳi bija pieraduši vērtēt visas nodarbes vispirms no morālā viedokḷa. Piemēram, ir labi zināms, kā klasiskie teksti slavē zemkopību par to, ka tā apmierina visas pilsoṇu svarīgākās vajadzības, reizē arī stiprinot viṇu miesu un garu. Šie paši teksti nosoda amatniecību un tirdzniecību par to, ka tās kaitē garīgai un fiziskai veselībai (Od., XVIII, 366-379; Xen. Oec., IV, 2-4; V, 1-12; Arist. Pol., 1277a 36 - 1277b 3; 1278a 6-7).

${ }^{21}$ Tā informācija, ko mēs zinām par Antifontu, liecina, ka šāds domu gāiiens patiešām varēja būt raksturīgs viṇam: piemēram, ir saglabājies fragments no Platona (komēdiju autora, ne filozofa) komēdijas Peisandrs, kurā tiek apsmieta Antifonta alkatība (Ps. Plut. Antiph.). Turklāt Antifonts pauda radikālas, pat revolucionāras idejas (piemēram, ideju par visu cilvēku vienlīdzību pēc dzimšanas: Fragm. 44B. Col. 2 DK) un aktīvi nostājās pret dižciltīgiem aristokrātiem (sīkāk sk.: Лурье 2009; Суриков 2008, 77 сл1.). Tas viss raksturo viṇu kā radikālas antiaristokrātiskās ideologijas pārstāvi. Ja tam pievieno vēl arī konkurences faktoru, tad Antifonta konfrontācija ar Sokratu, kurš aizstāvēja tradicionālās vērtības, kḷūst ḷoti likumsakarīga un dabiska. Kā zināms, Plūtarham pat slaveno tēlnieku un dzejnieku darbs liekas brīva cilvēka necienīgs (Plut. Per., II).

22 Protams, mūsdienās valdošā tendence ir noraidīt Platona liecības par sofistiem kā neobjektīvas un tēlot sofistus „baltus un pūkainus”, vienīgi kā speciālistus rētorikas un tiesību nozarē - sk.: Maier 1913, 198ff, 201ff; Martens 1992, 28f; Böhme 1992, 28; Irmscher 1985, 69; Johnson 1998, 203ff; Woodruf 2011, 37ff etc., etc. Tomēr liekas, ka tas ir pārspīlēti un ka mums nav pamata neticēt Platona liecībām. Protams, viṇš asi polemizēja ar sofistiem, bet tas vēl nenozīmē, ka vinš̌ būtu vinus apmelojis. Jānem vērā tomēr tas apstāklis, ka mazas face to face sabiedrības apstākḷos nav iespējams publiski apmelot sabiedrībā labi pazīstamus cilvēkus bez negatīvām sekām pašam priekš sevis. Šādā situācijā cilvēks, kurš iesaistās publiskā polemikā ar citiem, ir spiests korekti atveidot savu oponentu argumentus. Platons bija nopietns autors un nevēlējās iegūt mela vai Minhauzena reputāciju, tādēḷ ir jādomā, ka viṇš sniedz mums visai korektu informāciju par sofistiem. Viņš varēja sabiezināt krāsas, bet ne melot un sagrozīt faktus. Un uz kāda pamata mūsdienu pētnieki var apgalvot, ka viṇi labāk pazīst sofistus nekā Platons? Tas viss liek domāt, ka mūsdienu pētnieku simpātijas pret sofistiem un antipātijas pret Platonu/Sokratu ir ideologiiski nosacìtas. Ir acīmredzami, ka sofistu pasaules uzskats ir loti tuvs mūsdienās valdošajam un ka Platona uzskati un vērtības ir krasā pretrunā ar mūsu uzskatu sistēmu.

23 Vienā fragmentā no nesaglabājušās Euripīda traǵēdijas ir šādi vārdi: es neieredzu gudro, kurš nav gudrs priekš sevis (Fragm. 95 N.-Sn.). Tā ir vēl viena liecība par labu tam, ka Euripīdam bija līdzīgi priekšstati par gudrību un radošu darbu kā sofistiem. Tas ḷauj labāk saprast, kādēḷ Aristofans tik ḷoti viṇam uzbruka savās komēdijās.

24 Piemēram: Maier 1913, 241f, 253, 257f; Лосев 2000, 11.

25 Sk.: Romilly 2002, 134-161.

26 Mūsdienās politkorektuma valodā šì sofistikas morālā bezatbildība tiek dēvēta par „ētiski neitrālo", tīro mākslu jeb meistarību: Johnson 1998, 201, 204.

27 Lai gan Protagors bija liels meistars šajās lietās, tomēr viens viṇa skolnieks, vārdā Euatls, izrādījās vēl veiklāks par vinu un atrada veidu, kā ar viltības un rētorikas palīdzību nesamaksāt skolotājam pusi no solītās summas par apmācību (Aul. Gell., V, 10; Apul. Flor., XVIII; Diog. Laert., IX, 54). Tātad sofisti patiešām visvairāk vērtēja māku panākt savu mērḳi bez jebkādiem morāles ierobežojumiem.

28 Šis dialogs satur tik daudz principiālu uzstādījumu, ka to var uzskatīt par Sokrata (un sokratiskās) domas manifestu. Tādēḷ tas piesaista īpašu pētnieku uzmanību: Kahn 1983, 75-121; Klosko 1984, 126-139; Йегер 1997, 140-168. Etc., etc., etc. 
29 Protams, mūsdienās tiek mēǵināts pierādīt, ka dialoga jēga ir cita, nekā liekas, izlasot pirmo reizi, un ka Kallikls - Sokrata galvenais oponents - nemaz nav tāds hedonists, kāds viņš liekas, un ka Sokrats grib teikt ne to, ko viņš saka, utt. - sk. piemēram: Stauffer 2002, 647f, 654ff. Taču, lasot šo dialogu bez ideoloǵiskās ievirzes, visi šie prātuḷojumi izskatās pēc nepamatotas sofistiskas rētorikas, kas cenšas ieraudzīt tekstā to, kā tur nav. Šḳiet, ka tam visam ir tikai viens mērkisis - padarīt sofistus vēl „,baltākus un pūkainākus" un apšaubīt Sokrata autoritāti, parādot viṇu pēc iespējas „,ne tādu”, „neīstu”. Tomēr tas viss ir baltiem diegiem šūts.

30 Šis Gorgija aspekts jau vairākkārt ticis apspriests, velkot paralēles ar Euripīda Antiopi, kur slavenajā Zeta un Amfiona dialogā tika uzdots šis jautājums: Nightingale 1992, 121-141; Stauffer 2002, 627-657; Фестюжьер 2009, 35 сли.

31 Par audzināšanas vietu un nozīmi Sokrata sistēmā īpaši sk.: Йегер 1997, 59-100.

32 Starp citu, iespējams, ka tieši tādēḷ Sokrats, atšķirībā no sofistiem, kuri klīda pa pasauli naudas meklējumos, nekad nepameta savu dzimto pilsētu, pat riskējot ar dzīvi. Tas kḷūst saprotams, ja pieņemam, ka par savas dzìves jēgu viņš uzskatīja kalpošanu savai pilsētai.

\section{BIBLIOGRĀFIJA}

Benson, Herman. Socratic Wisdom. New York, 2000.

Böhme, Georg. Der Typ Sokrates. Frankfurt a. M., 1992.

Burnet, Jones. Greek Philosophy. London, 1914.

Chroust, Anton - Herman. Socrates: Man and Myth. London, 1957.

Colaiaco, James A. Socrates against Athens. Philosophy on Trial. New York, 2001.

Donlan, Walter. The Tradition of Anti - Aristocratic Thought in the Early Greek Poetry. Historia, 22, 1973, 145-154.

Dorion, Lois - André. Xenophon's Socrates. S. Ahbel-Rappe, R. Kamtekar (Eds.). A Companion to Socrates. Blackwell, 2006, 93-109.

Dupréel, Eugene. La légende Socratique et le sources de Platon. Bruxelles, 1922.

Easterling, Patricia Elizabeth. Constucting the Heroic. Ch. Pelling (Ed.). Greek Tragedy and Historian. Oxford, 1997, 21-37.

Egermann, Franz. Vom Attischen Menschenbild. Arete und tragische Bewusstheit bei Sophokles und Herodot. New York, 1979.

Ehrenberg, Victor. Sophocles and Pericles. Oxford, 1954.

Fischer, J. L. The Case of Socrates. Prag, 1969.

Gigon, Olof. Sokrates. Bern, 1947.

Guardini, Roberto. Der Tod des Sokrates. Mainz, 1987.

Guthrie, William Keith Chambers. Socrates. Cambrige, 1971.

Irmscher, Johannes. Sokrates. Leipzig, 1985.

Jaeger, Werner. Paideia. Die Formung des griechischen Menschen. Berlin, Bd. 1-3, 1934.

Jaeger, Werner. Solon's Eunomia. W. Eisenhut (Hrsg.). Antike Lyrik. Darmstadt, 1970, 7-31. Jöel, Karl. Der echte und xenophontische Sokrates. Berlin, 1893-1901.

Johnson, Steve. Skills, Socrates ad the Sophists: Learning from History. British Journal of Educational Studies, 46, 2, 1998, 201-213.

Kahn, Charles. Drama and Dialectic in Plato's Gorgias. Oxford Studies in Ancient Philosphy, 1, 1983, 75-121.

Klosko, George. The Refutation of Callicles in Plato's Gorgias. Greece and Rome, 31, 1984, 126-139.

Knox, Bernard. The Heroic Temper. Studies in Sophoclean Tragedy. Berkeley, 1964.

Maier, Heinrich. Sokrates. Tübingen, 1913. 
Manuwald, Bernd. Zu Solons Gedankenwelt. Rheinisches Museum für Philologie. Bd. 132, Heft 1, 1989.

Martens, Ekkehard. Die Sache Sokrates. Stuttgart, 1992.

Melchinger, Siegfried. Die Welt als Tragödie. Aishylos, Sophokles. Bd. 1. München, 1979.

Mosse, Claude. Der Prozess des Sokrates. Hintermänner, Motive, Auswirkungen. Freiburg, 1999.

Navia, Luis. The Socratic Presence: A Study of the Sources. New York, 1993.

Nightingale, Andrea Wilson. Plato's Gorgias adn Euripides' Antiope. Classical Antiquity, 11, 1992, 121-141.

Pleger, Walter. Sokrates. Der Beginn des philosophischen Dialogs. Hamburg, 1998.

Podlecki, Antony. The Political Background of Aeshylean Tragedy. München, 1996.

Pohlenz, Max. Aus Platos Werdezeit. Berlin, 1913.

Roisman, Hanna. Sophocles. Philoctetes. London, 2005.

Romilly, Jacqueline de. The Great Sophists in Periclean Athens. Oxford, 2002.

Seybold, Karl, Ungern-Sternberg, Jürgen von (Hrsg.). Amos und Hesiod. Aspekte eines Vergleichs. K. Raaflaub (Hrsg.). Anfänge politisches Denkens in der Antike. München, 1993, 215-239.

Stauffer, Devin. Socrates and Callicles: A Reading of Plato's Gorgias. The Review of Politics. Vol. 64, Nr. 4, 2002, 627-657.

Stone, Irving. Der Prozess gegen Sokrates. Wien, 1990.

Wallach, John. The Platonic Political Art. University Park Pennsylvanina, 2001.

Waterfield, Robert. Why Socrates Died. Dispelling the Myts. London, 2009.

Woodruf, Paul. The Ajax Dilemma. Justice, Fairness and Rewards. Oxford, 2011.

Иосев, Александр Федорович. История античной эстетики. Софисты, Сократ, Платон. Москва, 2000.

Аурье, Соломон Яковлевич. Антифонт - твореи древнейшей анархической системы. Москва, 2009.

Рассел, Бертран. История западной философии. Москва, 2002.

Соболевский, Сергей Иванович. Комментарии. Воспоминания о Сократе. Ксенофонт. Воспоминания о Сократе. Москва, 1993.

Суриков, Игорь Евгеньевич. ANTIPHONTEA III. Друзья и враги Антифонта (просопографический этюд). Studia Historica VIII. Москва, 2008.

Фестюжьер, Андре - Жан. Созерияание и созерияательная жизнь по Платону. Пер. А. С. Гагонина. Спб., 2009.

Йегер, Вернер. Пайдейя. Воспитание античного грека (эпоха великих воспитателей и воспитательных систем). Пер. А. И. Любжина. Т. 1-2. Москва, 1997-2001.

Ярхо, Виктор Ноевич. Софокл. Жизнь и творчество. Москва, 2005.

Harijs Tumans, University of Latvia, Latvia

THE HELLENIC DISCUSSION ABOUT PAIDEIA

In this paper paideia will be understood more broadly - not only as education/learning but also as upbringing. Therefore, the Hellene discussion about paideia in this context means the debate about the purpose and meaning of upbringing/education. For a long time there was no public discussion on this topic in the Greek cultural space, because the nature of paideia seemed self-evident. It could be formulated very simply: to teach virtue $(\dot{\alpha} \rho \varepsilon \tau \eta \dot{\eta})$. In contrast to that, in the later, more rational 
classical period, new values were advocated and a new concept of education was proposed. These new concepts were brought by sophists, who undertook teaching, but no longer upbringing. As a result, the issue of education became topical in the Greek cultural area. The oldest text that raises the issue is the comedy Clouds by Aristophanes. The same issue was treated very similarly in the famous allegory of Prodicus about Heracles at the crossroads, who had to choose what to learn - probity or benefit. The issue was raised once again in Sophocles' play Philoctetes which portrays a young man choosing between probity and dishonesty.

The first open debate about the two paideias is represented in Aristophanes' comedy Frogs, which culminates in the discussion between Aeschylos and Euripides about the purpose of poets' creative works in the underworld. Aeschylos fights against the new art of drama without upbringing and praises the traditional conception of paideia, the purpose of which is moral upbringing. Serious ideological confrontation about the meaning of paideia developed in the polemics between Socrates and the sophists. Whereas Socrates represents the traditional point of view and believes that the main purpose of education is moral upbringing, the sophists considered moneymaking, fame and seizing power as the main goals, regardless of moral norms. Socrates (and/or Plato) advocates paideia that makes persons better and rejects the concept of paideia of the sophists, divested of morality and setting personal benefit as the goal.

It can be concluded that the Greek concepts of paideia has undergone a considerable evolution over time, and, as a result, the initial consensus was superseded by the polemics of the two radically opposite views. The analysis shows that the polemics of Socrates and the sophists was basically a confrontation of two worldviews. This indicates a breach not only in the understanding of paidea but also in the culture in general. Thus, the discussions of Hellenes about paideia can help us understand more deeply the meaning of the cultural breach in the Helladic culture ... 


\section{GITA BĒRZIN,A}

Latvijas Universitāte, Latvija

\section{SIMPOSIJS KĀ IZGLİTOŠANĀS INSTITŪCIJA SENAJĀ GRIEḲIJĀ}

\section{İss kopsavilkums}

Simposijs uzskatāms par unikālu Senās Griekijas sociālo kultūrfenomenu ar daudzveidīgu funkcionalitāti. Viena no būtiskākajām ir arī izglītošanās/audzināšanas funkcija dažādos aspektos. Kā aktuāla tā apzināta gan arhaiskajā un klasiskajā periodā, gan attiecīgā transformējumā arī turpmākajos laikos. Daudzveidīgs dzīru kultūrvides izglītojošo/audzinošo kvalitāšu iezīmējums rodams dažādu žanru tekstos, jau sākot ar Homēra eposu un arhaiskās lirikas piemēriem.

Rakstā, balstoties uz vairāku tekstu liecībām, tiek atklāti dažādi $\pi \alpha \iota \delta \varepsilon i ́ \alpha$ aspekti simposija kultūrvidē. Uzmanība pievērsta noteiktām indivīda/sabiedrības ètiskām vērtībām un nostādnēm, to specifiskai izpausmei un proponēšanai, arī

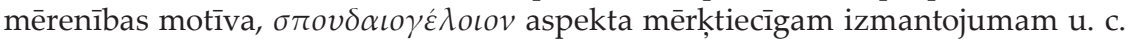

Atslēgvārdi: simposijs, audzināšana, izglītošanās, ētiskās vērtības.

Par vienu no unikāliem Senās Grieḳijas sociālajiem kultūrfenomeniem ar daudzveidīgu funkcionalitāti uzskatāms simposijs $(\sigma v v-/ \sigma v \mu-+$

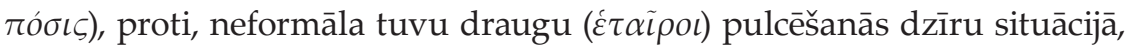

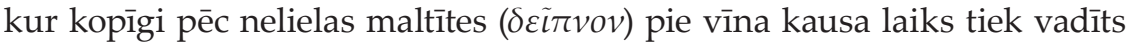
sarunās un dažādās izklaidēs. Tā aizsākumi grieķu kultūrā meklējami tālā senatnē, kopīgās sabiedriskās maltītēs, iespējams, rituālajās dzīrēs (sk. Murray 1990, 5-6; Schmitt-Pantel 1990), taču augstāko uzplaukumu simposijs piedzìvo arhaiskajā periodā no 7. līdz 5. gs. p. m. è. un turpina pastāvēt arī tālāk, kaut turpmākajos gadsimtos zaudē savu iepriekš tik būtisko funkcionālo nozīmi sabiedrības politiskajā, sociālajā un kultūras dzīvē.

Ar savu specifisko norisi, raksturīgām iezīmēm sengrieḳu kultūrvidē simposijs ir gan svarīgākā privātās sazināšanās, attiecību iedibināšanas un uzturēšanas, gan arī noteiktas identitātes sajūtas stiprināšanas forma, sevišḳi arhaiskajā periodā tas ir zināmā mērā nozīmīgs sociālās kontroles instruments, kā arī vide, kur tiek radīta un saglabāta poētiskā 
tradīcija un risinātas intelektuālas sarunas. Tā ir situācija un iespēja izjust gan fizisku, gan intelektuālu prieku.

Neskaitāmas liecības par to (gan ar specifiskiem mākslinieciskiem akcentiem) atrodamas vai visos sengrieķu literatūras žanros, sākot ar Homēra eposiem un arhaisko liriku un beidzot ar komēdiju un dažādiem prozas žanriem. Bet 4. gs. p. m. è., balstoties uz noteiktu sociokultūras praksi, sengrieḳu literatūrā izveidojas arī atsevišķa žanra forma - dialoga žanra paveids ar literārā simposija nosaukumu, kur dažādi autori tiecas fiksēt šo sengrieķu kultūrfenomenu atbilstoši saviem mākslinieciskajiem mērḳiem un pasaules redzējumam.

Viena no būtiskākajām sengrieḳu simposija funkcijām ir arī $\pi \alpha \iota \delta \varepsilon i \alpha$ - audzināšanas/izglītošanās funkcija dažādos aspektos. Kā aktuāla tā apzināta gan arhaiskajā un klasiskajā periodā, gan - attiecīgā transformējumā - arī turpmākajos laikos. Ierasti spilgtākais apliecinājums izglītošanās momentiem simposija situācijā pētìts Platona dialogā Dzīres (sk., piem., Jaeger 1986 (1943), 174-197; Campbell 2005 u. c). Tomēr daudzveidīgs dažādu dzīru kultūrvides izglītojošo/audzinošo kvalitāšu iezīmējums rodams arī citos tekstos, sākot ar pašiem agrīnākajiem.

Jau Homēra eposā Odiseja plaši vērojamas dažādas - gan veiksmīgu, gan neveiksmīgu - dzīru ainas. Un, tikai paraugoties uz vienu (gan izvērstāko) piemēru, proti, par godu Odisejam kā svešiniekam rīkoto Alkinoja dzīru atainojumu eposa 8. dziedājumā, ieraugāma virkne audzinošu/izglītojošu momentu.

Kā atsevišḳos pētījumos jau atzīmēts, Homēra eposs gan ataino episkas plaša mēroga varoṇu dzīres, ne simposiju šì vārda precīzākajā nozīmē, tomēr te atklājas virkne arī vēlākam simposijam raksturīgo elementu (sk. Henderson 2000, 8; Slater 1990, 213-217).

Fiksējamie $\pi \alpha \iota \delta \varepsilon i \alpha$ aspekti attiecas gan uz konkrēto svinību situāciju, gan noteiktām sabiedrības vērtībām plašākā kontekstā. Izvērsts Alkinoja rīkoto dzīru situācijas raksturojums iezīmē nepieciešamās dzīru norises, sākot ar viesu ielūgšanu (Od., 40-43), obligāto rituālo aspektu - upurēšanu, ziedošanu dieviem (Od., 8, 59-60; 89), tad ēdiena gatavošanu, pasniegšanu un baudīšanu (Od., 8, 61; 69-71; 484-5) un beidzot ar daudzveidīgo izklaižu daḷu, kas ietver gan dziesminieka priekšnesumu (Od., 8, 73-82; 266-366; 499-520), gan sarunas un dejas (Od., 8, 370-384), gan dažādas sacensības, lai savstarpēji pierādītu varoṇu izcilību (Od., 8, 110-265). 
Situācijas norišu atainojums savukārt kalpo kā pamats noteiktas šīs sabiedrības indivīdu izturēšanās, noteiktu morālētisko principu atklāšanai, iezīmējot vēlamo paraugu namatēva un viesu rīcībai un savstarpējām attieksmēm. Te iespējams minēt, piemēram, namatēva (Alkinoja) rūpes par svešinieka (Odiseja) viesmīlīgu uzņemšanu, par visu dzīru viesu vienlīdzìgu labsajūtu; viesa komplimentus par baudìto, redzēto un dzirdēto; vispār savstarpēju labvēlību un laipnības dzīru biedru starpā, t. sk. negribēta apvainojuma izlīdzināšanu ar atbilstoša gandarījuma sniegšanu; mērenu ēdiena un dzēriena baudīšanu; kolektīvu prieku kā augstāko dzīru mērḳi, ko veicina visas t. s. izklaižu daḷas norises, u. c.

Noteiktas asociācijas par proponējamām vērtībām rada arī eposa izteiksme, piem., leksiskais materiāls ar nozīmēm 'labs', 'skaists', 'mīlı̌š',

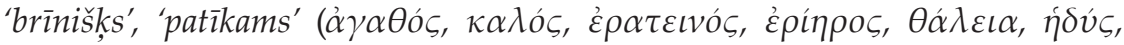
$\left.\pi \varepsilon \rho \iota \kappa \alpha \lambda \lambda \eta \zeta_{\varsigma}, \chi \alpha \rho i \varepsilon \iota \varsigma\right)$ līdzās dzīru reālijas un darbības raksturojošai lek-

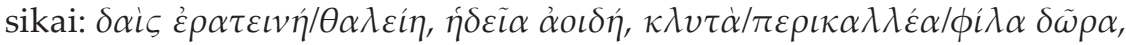

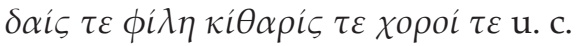

Visa eposa kontekstā Alkinoja dzīres pretstatā neveiksmīgajām precinieku dzīrēm kalpo kā ideālais modelis, kā $\pi \alpha \rho \alpha ́ \delta \varepsilon \iota \gamma \mu \alpha$. Tekstā to akcentē arī konkrēti izteikumi, vairāk vai mazāk didaktiskas norādes par to, kā noteiktā situācijā (bet vienlaikus - vispār) jāizturas krietnam vīram, šajā gadījumā - Homēra epu varonim.

Tas spilgti vērojams, piemēram, situācijā, kad Alkinojs, redzot, ka Odisejs atšķirībā no citiem nespēj baudīt dziesminieka vēstìto, bet raud, liek pārtraukt dziesmu, lai visi vienlìdz priecātos, un izsaka arī vispārinātu atziṇu, kas vienlaikus plašāk atspoguḷo noteiktas vērtības, proti, viesis un palīdzības lūdzējs ir kā brālis vìram, kuram kaut nedaudz prāta.

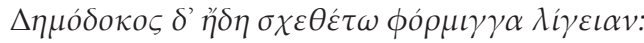

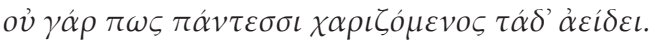

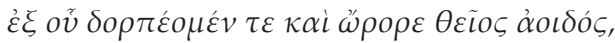

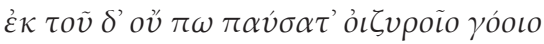

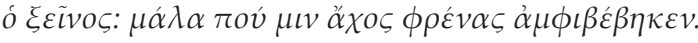

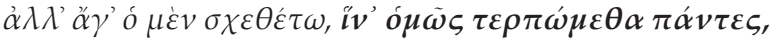

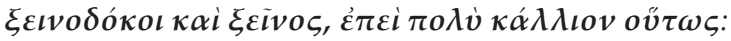

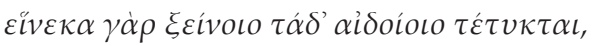

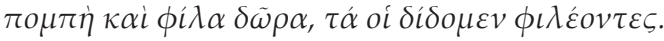

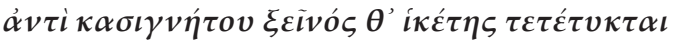

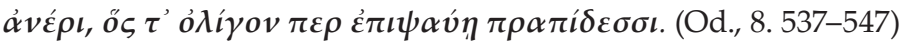


Vēl nozīmīgāk simposija (nu jau šì vārda precīzākā nozīmē!) kultūrvides audzinošos aspektus atspoguḷo arhaiskās lirikas teksti. Dzeja arhaiskajā periodā ir viens no svarīgākajiem līdzekḷiem tā laika cilvēka izglītošanai. Bet simposijs ir viena no pamatvidēm, kur poētiski teksti tiek radīti un izpildīti (Bowie 1986; Murray 1990, 9; Henderson 2000, 6).

Plašs tēmu loks atklājas simposija dzejas tekstos: gan aktuālas valsts sociopolitiskās norises, gan daudzpusīgas indivīda izjūtas un morālas pārdomas, t. sk. cilvēka tikumiska uzvedība, attieksme pret dieviem, draudzība un mīlestība, arī pats simposijs vai tā elementi (sevišķi vīns un tā lietošana) un carpe diem motīvs. Šaurākā vai plašākā nozīmē šo tēmu risinājums arvien orientēts uz cilvēka audzināšanu, uz to, lai veidotu viņa izpratni par noteiktām vērtībām.

Ierasts poētiskos tekstos, kas paredzēti izpildīšanai simposijā, ir pašas simposija vides iezīmējums: ar atsevišķiem atslēgelementiem un šķietami sekundārām norādēm (piem., Sol., 26; Thgn., 237-43 u. c.) vai arī sīki un izvērsti, kā tas spilgti vērojams, piemēram, Ksenofana

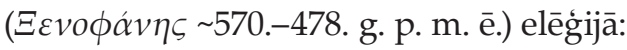

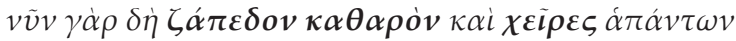

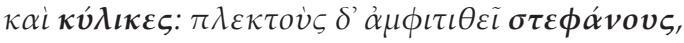

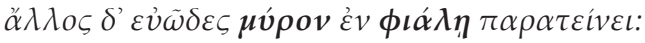

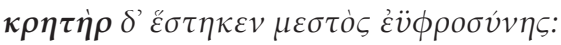

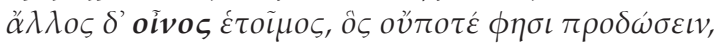

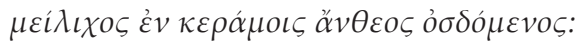

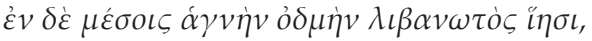

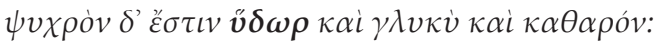

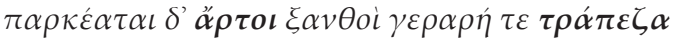

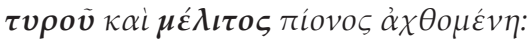

$\beta \omega \mu \dot{o} \varsigma \delta^{\prime} \ddot{\alpha} v \theta \varepsilon \sigma \iota v a ̈ v \tau \dot{\alpha} \mu \dot{\varepsilon} \sigma o v \pi \alpha ́ v \tau \eta \iota \pi \varepsilon \pi v ́ \kappa \alpha \sigma \tau \alpha \iota$

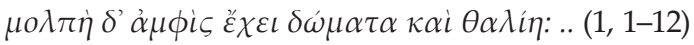

Elēgijā sniegts detalizēts vides raksturojums, kur minētas visas būtiskākās simposija reālijas un atribūti: tīra grīda, rokas un kiliki, pìti vainagi, smaržellla, kräters (prieka pilns), vīns un üdens, galdi pilni maizes, siera un medus, arī rituālā aspektā svarīgais altāris. Raksturojums „kā tas ir" patiesībā norāda "ka jābu ùt”. Taču dzejnieka nodoms nav tikai sniegt pamācību par ideālu telpas iekārtojumu. Kā atklāj tālākais teksts, detalizētais vides iezīmējums kalpo par būtisku fonu un atslēgu attiecīgiem 
morāla rakstura uzstādījumiem teksta 2. daḷā: vides tīrību atbalso ētiska tīrība/skaidrība.

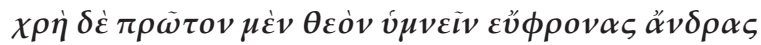

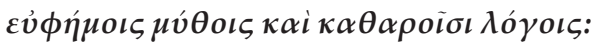

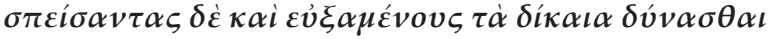

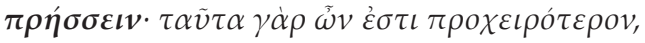

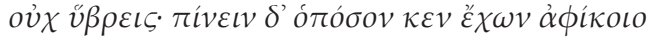

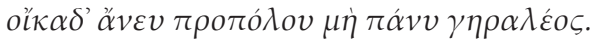

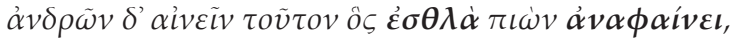

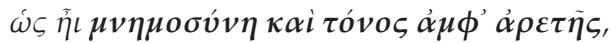

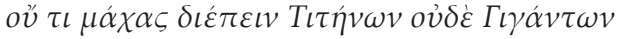

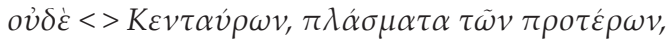

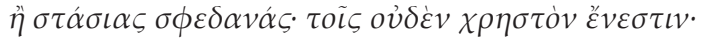

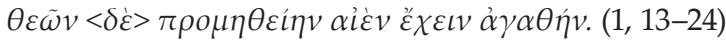

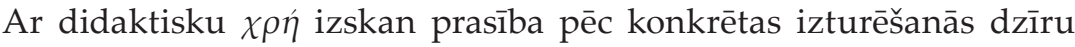
situācijā: nepieciešamība godāt dievus (labiem stāstiem un tīriem vārdiem!),

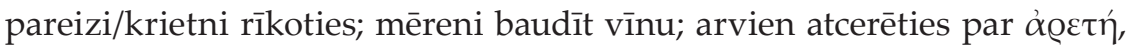
izvairīties runāt/dziedāt par titānu un gigantu, kentauru cīṇām, nesaskaņām. Tā vides raksturojums un cilvēka iesaiste konkrētās simposija norisēs kalpo par pamatu indivīda atbilstošas izturēšanās prasījumam un ir cieši saistīts ar noteiktiem ētiskiem aspektiem.

Lìdzīgi arī citos dzejas tekstos nereti vērojam didaktiskas pamācības par simposija specifisko vidi un norisēm, bet vēl jo vairāk par to, kādai jābūt svinēšanai, kā simposija viesiem, t. i., pilsoṇiem, konkrētās sabiedrības locekḷiem jāuzvedas. Būtiskas norādes dzejas rindās izskan par situācijai piemērotu gan fizisko, gan morālētisko, t. sk. verbālo, uzvedību: harmoniski, ar mierpilnu prieku baudīt svētku atmosfēru (Afrodītes, Mūzu, Dionīsa veltes) (piem., Thgn., 211-212, 309-312, 467-496, 533-534, 789-792; Anacr., 2.1-4); vienlīdzīgi un labvēlīgi izturēties pret visiem dzīru līdzbiedriem (sal. Thgn., 757-768); godāt dievus; nerunāt/nedziedāt par cīnāam un strīdiem, bet par patīkamām tēmām (Anacr., 2.1-4; Phoc., 14.1-2; Stesich., 33); arvien atcerēties par krietno un godājamo.

Simposija videi un specifiskām norisēm vispār ir būtiska nozīme cilvēka rakstura atklāšanā un tālāk attiecīgi arī tā veidošanā. Atminoties slaveno izteicienu, iespējams teikt, ka simposijs nozīmīgi

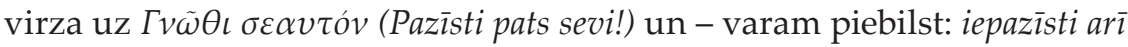
otru! - piepildījumu. 
Neoficiālā, brīvā vide - vīna baudīšana, dzeja, mūzika, smiekli, neformālas sarunas, arī spēles - veicina dzīru viesu atbrīvošanos.

Jo īpaša loma šai ziņā ir vīnam. Simposija tekstos tas ir viens no dominējošiem elementiem un īpaši tiek izcelta - kā labi zinām no Alkaja

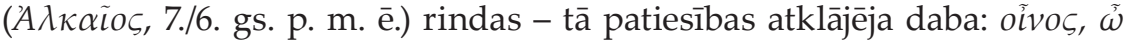

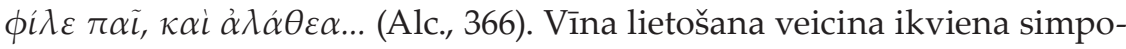
sija dalībnieka gara un prāta atbrīvošanu un mudina patiesi atklāt visu, ko tie zina, redz, domā un jūt. Un šai atslābšanai, sevis atklāšanai ir jo svarīga nopietnā - $\pi \alpha \iota \delta \varepsilon i \alpha$ - puse: iepazìt sevi un citus, izdarot vērtīgus secinājumus, kas noderīgi tālākai sevis pilnveidei un citu audzināšanai.

Neskaitāmas liecības to fiksējušas dažādu žanru tekstos (arī vēlākos), ne tikai lirikā. Tā, piemēram, filozofisko dialogu autors Platons ( $\Pi \lambda \alpha ́ \tau \omega \nu$, 427.-348. g. p. m. ē.) sava vēlīnā darba Likumi 1. un 2. grāmatā, raksturojot ideālu simposiju, norāda, ka tā ir svarīga izglītošanās daḷa, un līdzās virknei citu būtisku aspektu atzīmē pareizas vīna baudīšanas lietderību

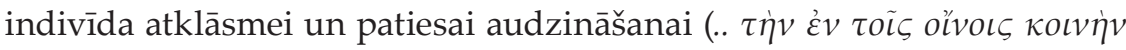

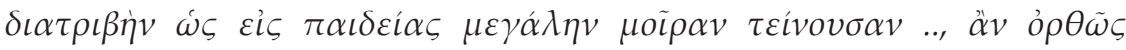
$\gamma^{\prime} \gamma v \eta \tau \alpha \iota$..) (Pl. Lg., 641A-642A).

Savukārt dažus gadsimtus vēlāk cits prozas autors Plūtarhs

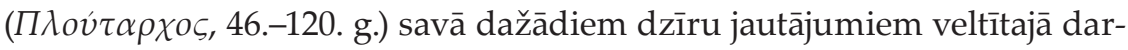
bā Quaestiones convivales, izvērsti runājot par vīna lietošanu, stāsta par dzejnieku Simonīdu, kurš, redzēdams, ka viens no viņa dzīru biedriem klusē un neko nesaka, norādījis tam: Ja tu esi mulk,kis, tu rīkojies gudri, bet ja gudrs cilvēks, tad muḷkīgi (Plut. Quaes. Conv., 644F-645C).

Tādējādi, kā atklāj tekstu liecības, izpratne par atbilstošu (griekiem tik svarīgo $\pi \rho \dot{c} \pi o v)$ rīcību simposija situācijā paredz, ka dzīru biedri brīvajā svinību atmosfērā atklāj savus uzskatus un raksturu, iepazīst cits citu un apmainās zināšanām un idejām.

Vienlaikus te zīmīgi realizējas arī viena no simposija kultūrfenomena raksturīgākajām kategorijām, kas arvien fiksēta visos attiecīgajos

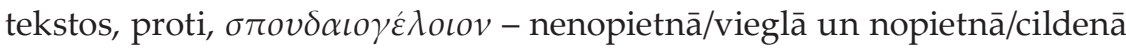
apvienojums. Simposija konteksts paredz $\gamma \varepsilon \lambda$ oĩov pusi - vīnu, smieklus, izklaides, atbrīvotu, nepiespiestu uzvedību, taču tas nav uztverams kā

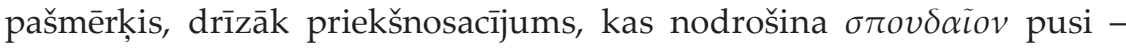
nopietnu ideju un vērtību paušanu un apgūšanu. Tādā vai citādā veidā tas atklājas gandrīz visos gan dzejas, gan prozas tekstos, kuri iezīmē simposija realitāti (sk., piem., Кислова 1973; Bērziņa 2009). 


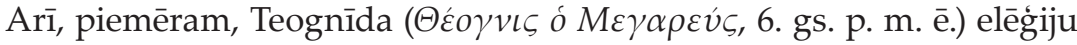
korpusā, kas pamatā veidots kā vecāka aristokrāta padomi jauneklim (galvenokārt Kirnam) par atbilstošu dzivesveidu, redzams savdabīgs

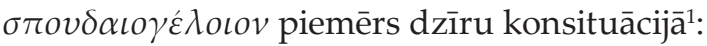

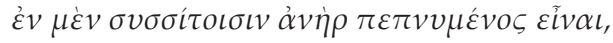

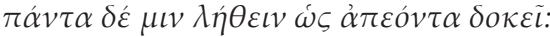

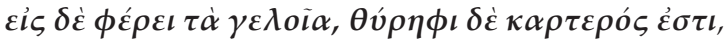

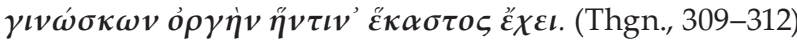

Šajās rindās lasāma skaidra norāde par to, ka gudrs dzīrotājs (ảvì

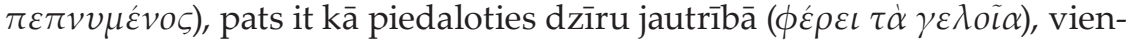
laikus no malas $(\theta \dot{v} \rho \eta \phi \iota)$ vēro citus, iepazīst to raksturus, vērtē un - kā saprotam - vēlāk izmanto savus vērojumus (sal. Thgn., 491-496, 563-566; Ion, 26, 15-16).

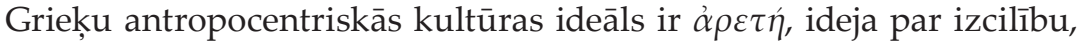
kas ir arī grieḳu $\pi \alpha \iota \delta \varepsilon i \alpha$ pamatā. Poles pilsoṇa ideāls ir $\kappa \alpha \lambda o ́ \varsigma \kappa \alpha \dot{\alpha} \gamma \alpha \theta o ́ \varsigma$, krietns vīrs ar harmonisku fizisko veidolu un perfektu ètisko un sociālo uzvedību. Bet simposija vide ar savu brīvo atmosfēru ir neatnemama privātās dzīves daḷa $\kappa \alpha \lambda o \varsigma_{\varsigma} \kappa \dot{\alpha} \gamma \alpha \theta o ́ \varsigma$ indivīda vispusīgai $\alpha \rho \varepsilon \tau \eta \dot{~ a u d z i n a ̄-~}$ šanai, izkopšanai un piln̄̄gošanai. Apliecinājumu tam redzam gandrīz visos atbilstošajos arhaiskā un arī vēl klasiskā perioda tekstos.

Atbrīvotības un tās nodrošinātās $\pi \alpha \iota \delta \varepsilon i ́ \alpha$ kontekstā îpaši svarīgs gan ir mērenības aspekts. Simposija realitāti atainojošajos tekstos mērenības motīvs lakoniskākā vai - tieši otrādi - izvērstā formā vērojams kā arvien klātesošs. Tas visbiežāk saistīts ar vīna lietošanu un izpaužas galvenokārt divējādi: vai nu dzejniekam izceḷot mērenības pozitīvos aspektus un aicinot nedzert pār mēru, vai arī - tieši otrādi - izvērsti sniedzot negatīvos pārmērību (vīna raisīto seku) paraugus². To spilgti ilustrē, piemēram, Teognīda korpusa rindas:

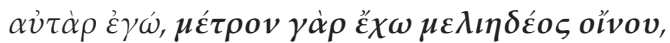

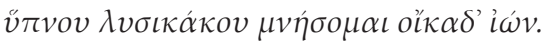

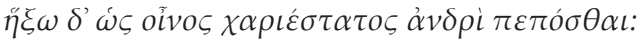

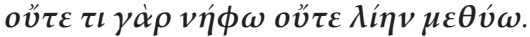

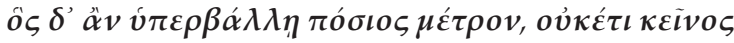

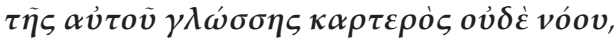

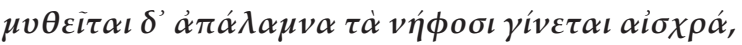

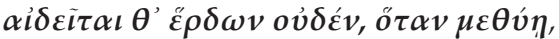




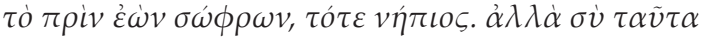

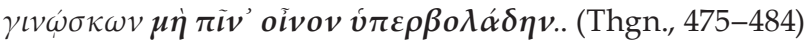

Dzejnieks 1. personas formā akcentē es ievēroju mēru un tam pretstata raksturojumu - kurš to pārsniedz/neievēro, vairs nevalda ne pār savu mēli, ne prātu, bet runā nekrietnu un rīkojas apkaunojoši, dzejniekam beidzot ar didaktisku imperatīvu nedzer vīnu pār mēru!

Vai citviet - ironisks pārmērīga vīna baudījuma rezultāts es formā:

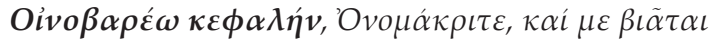

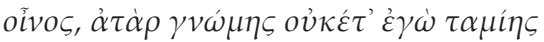

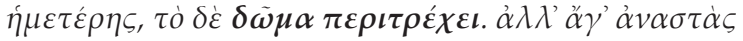

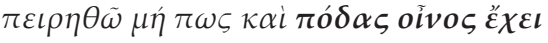

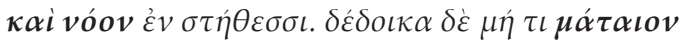

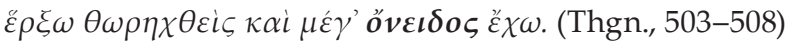

Man smaga galva, vīns nospiě̌, māja riņ̧̧̄i skrien, vīns valda pār kājām un prātu; liriskais varonis visbeidzot baidās izdarìt ko muḷ, $\bar{g} \mathrm{~g} u$ un krist negodā.

Mērenības ievērošana saistāma ar saprātu, tas nozīmē vispār krietnu, situācijai atbilstošu rīcību, tikumisko normu ievērošanu, turpretim pārmērība, mēra neievērošana paredz fiziski negatīvas izjūtas, neadekvātu izturēšanos, nesaprātību, nekaunību, muḷịību un negodu.

Jāatzīmē, ka mērenības motīvs nav interpretējams tikai šauri dzīru situācijas kontekstā, bet ir visspilgtākais apliecinājums simposija kultūrvides elementu plašākai nozīmei. Šì motīva izmantojums ikvienā ar simposiju saistītā tekstā liek domāt par mēra ievērošanu ne tikai vīna lietošanā dzīru situācijā, bet ikkatrā rīcībā un jomā̄a . Visās lietās grieḳi meklē harmonisku mēru, un simposija teksti ar konkrētā - noteiktā realitātē balstītā - motīva izmantojumu par to atgādina.

Simposija augstākais baudījums $\varepsilon \hat{v} \phi \rho o \sigma v ́ v \eta$ rodams līdzsvarotā,

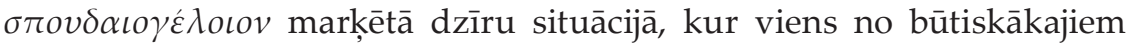
priekšnoteikumiem - noteikta simposija viesu tikumiskā uzvedība. Bet tā lielā mērā atspoguḷo vispārējos konkrētās sabiedrības ētiskos ideālus, kas ir svarīgi arī ārpus dzīru vides, laika un telpas.

Laikā, kad Grieḳijā dominē mutvārdu kultūra, simposija vide un situācija, kur liela nozīme ir dažādu paaudžu indivīdu kopā būšanai un kopīgai mielasta un izklaižu baudī̌sanai, sniedz kopienas mikromodeli 
un ir viena no būtiskākajām vietām pilsoṇa izglītošanai/audzināšanai visdažādākajos aspektos.

Ikviens dzīru viesis caur savu un citu pieredzi neformālajā, atbrīvotajā situācijā pilnveido savu raksturu, mācās būt krietns konkrētās kopienas loceklis - veidot attiecības, izprast un apgūt kopīgās vērtības. To plaši apliecina arī dažādu žanru tekstu liecības.

Turklāt jāatzīmē, ka simposija fenomens - visciešākajā saistībā ar $\tau \alpha \iota \delta \varepsilon i ́ \alpha$ - savā ziṇā nozīmi saglabā cauri ilgiem gadsimtiem un, lai arī transformētā formā, aktuāls ir arī mūsdienās. Mēs taču joprojām izmantojam simposija vārdu noteiktām intelektuālām aktivitātēm.

\section{ATSAUCES}

1 Šeit gan Spartas ekvivalentā - sisitijā.

2 Sal. Arhil., 41; pārmērība arī nereti simboliski ilustrēta ar kentauru un satīru pieminējumu: sk. Henderson 1990, 20-22.

3 To arī apliecina teksti, kur runāts par mērenību plašākā nozīmē, piem., Sol., 4.7-10.

\section{BIBLIOGRĀFIJA}

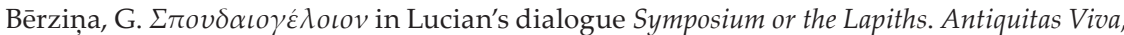
3: Studia Classica. Rīga : LU Akadēmiskais apgāds, 2009, 73.-83. lpp.

Bowie, E. L. Early Greek Elegy, Symposium and Public Festival. Journal of Hellenic Studies, 106, 1986, 13-35.

Campbell, J. St. J. O. Eros, Paideia and Arête: The Lesson of Plato's Symposium. Graduate School Thesis and Dissertations. University of South Florida, 2005.

Homeri Odyssea. Vol. I Rec. A. Ludwich. Lipsiae : Teubner, 1889.

Henderson, W. J. Aspects of the ancient Greek Symposion. Akroterion, 45, 2000, 6-26.

Jaeger, W. The Symposium: Eros. Paideia: The Ideals of Greek Culture. Vol. II. Oxford : University Press, 1986 (1943), 174-197.

Murray, O. Sympotic History. Sympotica: A Symposion on the Symposion. Oxford : Clarendon Press, 1990, 3-13.

Platonis Dialogi. Vol. V Rec. C. F. Hermanni. Lipsiae : Teubner, 1910.

Plutarchi Moralia. Rec. C. Hubert. Leipzig : Teubner, 1938.

Schmitt-Pantel, P. Sacrificial Meal and Symposion: Two Models of Civic Institutions in the Archaic City? Sympotica: A Symposion on the Symposion. Oxford : Clarendon Press, 1990, 14-33.

Slater, W. J. Sympotic ethics in the Odyssey. Sympotica: A Symposion on the Symposion. Oxford : Clarendon Press, 1990, 213-220.

Young, D. Theognis. Leipzig : Teubner, 1971.

West, M. L. Iambi et elegi Graeci, vol. 2. Oxford : ClarendonPress, 1972.

Кислова, М. М. Типы «смешного» в «Пире» Платона. Вопросы классической филологии, 5. Москва : Издательство Московского Университета, 1973, 158-169. 
Gita Bērziṇa, University of Latvia, Latvia

\section{SYMPOSIUM AS AN INSTITUTION OF EDUCATION IN ANCIENT GREECE}

Symposium is considered a unique ancient Greek socio-cultural phenomenon of a versatile functionality. One of the most important functions, among others, in different aspects, is also the educational/instructional one. Its topicality has been identified during the archaic and classical periods, as well as in pertinent transformations in subsequent times. A multifarious featuring of educational/edifying qualities pertaining to the culture of feasts can be found in texts of different genres, beginning already with examples of Homeric epic and archaic poetry.

Based on the evidence of a number of literary texts (Homer's Odyssey, lyrics of Xenophanes, Theognis and others, also some works by Plato and Plutarch), the article discloses various aspects of $\pi \alpha \iota \delta \varepsilon i \alpha$ in the cultural environment of symposium. Attention has been paid to certain ethical values and standpoints of an individual/society, their specific expression and advocacy, including a purposeful use of the theme of temperance, the aspect of $\sigma \pi o v \delta \alpha \iota \gamma$ ć $\lambda$ oıov, etc.

The analysis confirms that the symposium environment, with its liberated, atmosphere, is an integral part of private life for the all-round upbringing and perfection in $\dot{\alpha} \rho \varepsilon \tau \eta \dot{~ o f ~ a ~} \kappa \alpha \lambda \dot{\alpha} \varsigma \kappa \dot{\alpha} \gamma \alpha \theta o ́ \varsigma$ individual, and its elements and features in literary texts reflect the shared ethical ideals of the public. 
Athens, Greece

\section{DOCTA PUELLA IN THE ELEGIES OF PROPERTIUS: THE REFLECTION OF THE EDUCATION SYSTEM IN ROME IN THE TIME OF AUGUSTUS.}

\section{Brief summary}

The purpose of this paper is to reconstruct the education of a docta puella in order to reveal why such a woman captures the poet-lover so intensively that he, the poet, devotes his poetry to her despite the fact that this type of woman was supposed to lack traditional virtues. For the purpose of this presentation, Propertius's docta puella, Cynthia, is chosen as a characteristic example of the elegiac woman. My intention is to explore the historical and educational background of the Augustan time to understand the cognitive level of the woman of that era.

Key words: Docta puella, doctus poeta, roman elegy, Cynthia, Propertius.

The purpose of this paper is to reconstruct the education of a docta puella in order to reveal why this woman captures the poet-lover so intensively that he, the poet, devotes his poetry to her despite the fact that this type of woman was supposed to lack traditional virtues. For the purpose of this paper, Propertius's (Sextus Propertius 50 BC - 15 BC) docta puella, Cynthia, is chosen as a characteristic example of the elegiac woman. My intention is to explore the historical and educational background of the Augustan time to understand the cognitive level of the woman of that era.

Although women in the Roman elegy are literary figures, they also reflect the real status of women in the era of Augustus. They are described with a certain concern for realism, and they fit into the historical context. Even if the puella is not an actual person, she does relate to the Roman realities of status, society and gender (Wyke 1987, 47-61). Studying their educational background is a way of understanding this context and the elegiac poet's vision of it. It is remarkable that Propertius uses Cynthia's appearance and ways of living and acting in a conscious examination of how elegy constructs gender roles and in a broad critique of the associated values of Romanitas, its ideologies of gender, 
social structures, status, and political roles. It is important to mention that the origination and development of Roman elegies, as a literary fact, take place amid a massive cultural change. Elegy is a literary testimony of social and political events, such as the failure of the old Republic, and it is critical of the Roman imperialism related to the senatorial regime (Boucher 1965, 13). The political turbulence generates a crisis that affects the whole society. Thus, the elegiac ideal is a revolt against this world of disorder, and this revolt can be expressed in various ways and by various procedures. Propertius prefers to wage a literary war so as to divert and separate his poetry from other universal models, placing his beloved Cynthia in the very centre of his work.

The narrative organization of Propertius' Elegies seems to encourage a practice of reading the characters and events of his love elegy as real. Direct addresses to his beloved Cynthia, endowed with specific physical and psychological characteristics, suggest that the narrative's female subject has a life outside the text in which she is only Propertius' mistress (Wyke 1987, 47).

It is well known that the extraordinary beauty of women capture the attention of Roman elegiac poets. But it is not just the beauty and physical appearance that attract them. The elegiac woman is not just a means for pleasure; instead, she is the inspiration of the poet, the muse of his poetry, as in the case of Propertius. ${ }^{1}$ The poet can talk with his Cynthia about literature and acknowledge the pleasure of their meetings. ${ }^{2}$

The verse narramus multa uerba reflects a discussion between two people who enjoy debating about their own thoughts. Notably, the fact that the talk is a prelude to erotic games proves how much the representation of woman has changed: now men care about a woman's body and soul and about her mind inasmuch as her physical appearance (Laigneau 1999, 81). It matters that the puella is docta and is able to carry on the discussion. She not only shows external beauty but also displays rich knowledge, which enables the lovers to start a dialogue.

Propertius attributes to Cynthia a variety of talents ${ }^{3}$ and does not hesitate to affirm that they are more precious than her beauty. This personal talent is part of the general concept of the elegiac mistress. The first way to please her is obviously to praise her, not only on a physical stand but also on an artistic stand: Propertius attributes to her the gift of composing better poetry and music than the Greek poetess Corinna. ${ }^{4}$ This personal gift is a part of the general conception of the elegiac puella: 
for the young women to be attractive, they have to be able to sing well with the accompaniment of cithara and plectrum, to dance gracefully so as to delight the guests of a banquet, and to participate in games. It is well established, though, that in Rome singing and dancing were deemed to be disreputable activities unworthy of respectable women for a long time (Laigneau 1999, 62 and 64). In the Augustan era, women dancing during feasts were principally courtesans, luxury prostitutes, who, while selling their bodies, engaged in a less sordid activity than poor girls from Suburra. The dancers whom Propertius calls belong to the first category. They liven the feasts up delightfully, the poet brings them to his house, and they charm him with their dances. These courtesans seduce their customer with their beauty, elegance, and refinement.

Cynthia lives in this atmosphere, and her attitude fits into her environment (Boucher 1965, 470). In his paper about "the true Julia", J. Carcopino $(1958,86)$ summed up what could be the education and culture of a Roman woman in the Augustan time:

Roman women were confined to a women's apartment whose doors opened only for their closest male relatives and where they had to spin silently the amount of wool necessary for the family. Simultaneously, they were intellectually emancipated by their large and refined culture. They were taught by the best teachers from the Hellenic and Latin world, which gave them an early initiation to the rules of political eloquence and the bold doctrines of philosophers, and which elated them by the ardent declarations of poets whose love elegies they learned by heart.

Cynthia is a new type of woman: she is a Roman woman freed from the domination of the gens or the husband and is allowed to live freely. She is well-read, she can dance gracefully, she can sing, she is intelligent, fond of poetry and she also composes verses. In other words, she is characterized by elegance, refinement, beauty, wealth, social life and libertine moral standards. She is a docta puella, a modern woman, who knows and likes the Greek literature, Alexandrian poets, and art, and pursues a relaxed rhythm of life - graecari. This description embodies a picture of a high-class woman. In this way, precisely, the elegiac poets disagree with the "old Roman" mentality; they innovate and attribute to women a hugely different status from being only an object of pleasure. According to the Roman views, passion and intellectual or spiritual charms had a secondary place. Now, with the elegiac poets, love becomes to be based 
not only on physical attraction but also on reciprocal friendship and esteem (Copley 1965, 24).

Numerous sententiae can be found in the poems dedicated to Cynthia. Saying sententiae is the privilege of the docta puella (Catin 1957, 27-52), when wisdom goes hand in hand with a perfect mastery of poetical forms. Sententiae are characteristic of the doctus amans or doctus poeta too, as we can see in the elegies:

nudus Amor formam non amat artificem. ${ }^{5}$

differtur, numquam tollitur ullus amor. ${ }^{6}$

omne in amore malum, si patiare, leue est. ${ }^{7}$

uerus amor nullum nouit habere modum. ${ }^{8}$

The four verses, all of them being sententiae, express the truth of love in an expanded qualification (Barbaud 2002, 106).

Furthermore, the name of Cynthia can also be a proof of her culture and education; etymologically connected with Apollon Cynthius, her name reminds us that she is a poet; she participates in the ceremonies of the Muses and the poet regards her as one of the goddesses.

The name "Cynthia" has several connotations. First of all, it is important to point out the fact that free-born women were called by a literary nickname ending with -ia, like their gens name: Cynthia, Roscia or Hostia. Cynthia's pseudonym itself proves her ingenuitas, whereas all the pseudonyms ending with -is sound like names of slaves or cognomina of emancipated women, often of a Greek origin, like Nemesis for Tibullus (Boucher 1965, 464).

According to J.-P. Boucher (Boucher 1965, 461-462), the epithet Hostia is connected to the movement of neoteroi and to the new Latin poetry that was born during the time of extensive renewal of poetical genres, at Sulla's time in particular. Propertius as a writer cares too much about literary matters and doctrines to take the opposite view of the usual classification of his time. Even if he admires the success of the epic genre, he is still against the modern epic, and it is dubious that he wanted to qualify as doctus an old poet of the epic tradition, such as Hostius, the author of the Bellum Historicum, according to Ennius' tradition.

Very elegant and cultured, Cynthia lacks neither the "gifts of Venus nor those of Mimnermus", since Apollo has granted her the talent to compose poems and the muse Calliope - to sing to the accompaniment of a lyre. In the lyric verses and songs that she composes, she sounds 
inspired by the poetess Corinna, ${ }^{9}$ which is proof of good taste, even of erudition, as she adheres to the model confirmed over centuries and approved by educated people. It is also worth noting at this point that Corinna's poetry was rediscovered in the first century and was in fashion in circles as refined as the Maecenas' circle. At one point Cynthia is evoked in a very significant way, i.e. reading in a low voice the poems written by her lover to compensate for his absence ${ }^{10}$ - a typically elegiac motif. Cynthia is not only cultured; she can be witty and not boring in a discussion; she also dances remarkably. However, all these gifts would have worried an old-fashioned Roman, because a few women were so gifted - only very liberated women of the highest society and courtesans.

Female beauty is not a banal theme in the elegiac poetry; its presence and characteristics confirm the values of this poetry. Indeed, as E. Delbey states $(2001,201)$, the condemnation of jewels and of adornment with a specific vocabulary ${ }^{11}$ shows disagreement with the traditional morals and constitution of a space devoted to private passions, contrary to the official and public attitude. The way formosus is used is a sign of emerging values, such as individualism and privacy. They are therefore new values gathering and organizing themselves around the body and erotic images.

\section{REFERENCES}

1 II.1.3-4 non haec Calliope, non haec mihi cantat Apollo.

ingenium nobis ipsa puella facit "It is not Calliope, not Apollo that puts these songs in my mind: my sweetheart herself creates the inspiration" (translated by G. P. Goold).

II.1.15-16 seu quidquid fecit siuest quodcumque locuta, maxima de nihilo nascitur historia "whatever she has said, whatever she has said, from absolutely nothing is born a grand legend" (translated by G. P. Goold).

2 Propertius II.15.3-4 quam multa apposita narramus uerba lucerna, quantaque sublato lumine rixa fuit! "How many words we exchanged with the lamp beside us, and how much we wrestled when the light was put out!" (translated by G. P. Goold).

3 Propertius I.4.11-14 haec sed forma mei pars est extrema furoris;

sunt maiora, quibus, Basse, perire iuvat:

ingenuus color et motis decor artubus et quae

gaudia sub tacita discere veste libet "Yet this beauty is the least part of my frenzy; she has greater charms, Bassus, which I am glad to lose my head over: her well-bred complexion, her grace when she moves her limbs, and thrills I love to experience beneath the secrecy of the coverlet" (translated by G. P. Goold).

4 II.3.21-22 sua cum antiquae committit scripta Corinnae 
carminaque Erinnae non putat aequa suis "and when she pits her writings against those of ancient Corinna and deems Erinna's poems no match for her own" (translated by G. P. Goold).

5 I.2.8 "Love is naked, and loves not beauty gained by artifice" (translated by G. P. Goold).

6 II.3.8 "Love may be put off, but is never got rid of" (translated by G. P. Goold).

7 II.5.16 "In love every ill is light, if you but put up with it" (translated by G. P. Goold).

8 II.15.30 "True love knows no bounds" (translated by G. P. Goold).

9 II.3.21 sua cum antiquae committit scripta Corinnae "and when she pits her writings against those of ancient Corinna" (translated by G. P. Goold).

10 II.33.35-38 me miserum, ut multo nihil est mutata Lyaeo!

iam bibe: formosa es: nil tibi uina nocent,

cum tua praependent demissae in pocula sertae,

et mea deducta carmina uoce legis "Mercy on us! She is not a bit affected by so much drinking! Well, drink on: you are beautiful: wine harms you not at all when garlands hang over your face and dip into your cups and you read my poems with dainty voice " (translated by G. P. Goold).

11 Propertius I.2.8 nudus Amor satis forma non amat pudicitia "Love is naked, and loves not beauty gained by artifice"; II.18.25 ut natura dedit, sic omnis recta figurast "all beauty is best as nature made it" (translated by G. P. Goold).

12 Propertius II.1.3-4 ; II.1.15-16 non haec Calliope, non haec mihi cantat Apollo :

ingenium nobis ipsa puella facit...

seu quidquid fecit siuest quodcumque locuta,

maxima de nihilo nascitur historia.

13 Propertius II.15.3-4 quam multa apposita narramus uerba lucerna, quantaque sublato lumine rixa fuit!

\section{BIBLIOGRAPHY}

\section{Books (monograph)}

Viarre, Simone. Properce Elégies, texte établi, traduit et commenté. Paris, C.U.F., Les Belles Lettres, 2005.

Goold, George. Propertius Elegies, edited and translated. Harvard University Press, Cambridge, Massachusetts, London, 1990.

\section{Books (edited volume)}

Boucher, Jean-Paul. Etudes sur Properce, problèmes d'inspiration et d'art. Paris, 1965.

Carcopino, Jérôme. Passion et Politique chez les Césars. Paris, 1958.

Delbey, Evrard. Poétique de l'élégie romaine : les âges cicéroniens et augustéens. Paris, 2001.

Janan, Micaela. The Politics of Desire: Propertius IV. Berkeley, 2001.

Laigneau, Sylvie. La femme et l'amour chez Catulle et les élégiaques augusteens, coll. Latomus, vol. 249, Bruxelles, 1999.

\section{Articles in journals}

Barbaud, Thierry. La sententia amoureuse chez les élégiaques romains et notamment chez Properce, BAGB. Paris, 2002, 94-118.

Catin, L. Properce et Cynthie. BAGB 4, 1965, 1957, 27-52.

Copley, Frank Olin. Emotional conflict and its significance in the Lesbia - poems of Catullus. American Journal of Philology 70, 1965, 22-40.

Hallett, Judith. The Role of Women in Roman Elegy. Arethusa 6, 1973, 103-124. 
Wyke, Maria. Written women: Propertius' scripta puella. The Journal of Roman Studies, 77, 1987, 47-61.

Marija Gjannaki, Atēnas, Griek,ija

DOCTA PUELLA PROPERTIJA ELĒG̣IJĀS: IZGLĪTİBAS SISTĒMAS ATSPOGUL̨OJUMS AUGUSTA LAIKA ROMĀ

Ir labi zināms, ka elēǵiskos dzejniekus romiešu elēgijās saista sieviešu sevišķais skaistums. Taču viņu uzmanība veltīta ne tikai skaistumam un fiziskajam izskatam. Elēǵiska sieviete ir ne tikai prieka avots; viņa ir dzejnieka iedvesma, viṇa dzejas mūza, kā saka Propertijs ${ }^{12}$. Dzejnieks var runāt ar savu Kintiju par literatūru un apliecināt prieku par viṇu tikšanos ${ }^{13}$. Propertijs piedēvē viņai dažādus talantus (elēgija 1.4) un nevilcinās apgalvot, ka šīs dāvanas ir vērtīgākas par viṇas skaistumu. Šī personiskais talants pieder vispārējai koncepcijai par elēǵisku mịlāko.

Arī Kintijas vārds var kalpot kā viṇas kultūras un izglītības pierādijums; etimologiiski saistīts ar Apollonu Kintieti, viṇas vārds mums atgādina, ka viṇa ir dzejniece, piedalās mūzu ceremonijās, un dzejnieks uzskata viṇu par vienu tām.

Viṇa ir l,oti eleganta un izsmalcināta, un viņai netrūkst Veneras vai Mimnerma dāvanu, jo Apollons ir piešḳīris viņai dzejas sacerēšanas talantu un mūza Kalliope apveltījusi ar mākslu dziedāt liras pavadījumā. 


\title{
LİVA MUIŽNIECE
}

University of Latvia, Latvia

\author{
THE MEANING OF TO GENOS TOU EIDOUS \\ MEROS AND TO EIDOS TOU GENOUS MEROS IN \\ ARISTOTLE'S METAPHYSICS $\triangle 25$
}

\section{Brief Summary}

In his Metaphysics $\Delta 25,1023 b 24-5$ Aristotle juxtaposes to genos tou eidous meros and to eidos tou genous meros by saying that the genus is a part of the form in a different way (alloss) than the form is a part of the genus. The author of the article considers how to interpret the word allōs and argues for the idea that the contrast marked by allōs reveals two different meanings of meros, in each case expressing a different relation of parthood.

Keywords: Aristotle, part, form, genus, meaning.

\section{PREAMBLE}

The exploration of the idea that the genus is a part of the form (to genos tou eidous meros) in a different way (alloss) than the form is a part of the genus (to eidos tou genous meros) in Aristotle's Metaphysics $\Delta 25$, 1023b24-5 will proceed as follows: (i) the ambiguity marked by allōs will be examined; (ii) the ambiguity of meros will be posited; (iii) the ambiguity of genos and eidos will be dispelled, and (iv) the relations of parthood at work behind the ambiguity of meros will be elucidated.

In this article ambiguity is understood as term's bearing multiple meanings, and meaning is understood as sense or intension, or concept associated with a term, and it is what determines the referent of the term or the extension, or the object the term is true of. Thus, a term is ambiguous if it has multiple meanings, whether or not it has the same referent. If a term has different referents, then it has different meanings, although a term can have different meanings without having different referents. ${ }^{1}$

\section{THE AMBIGUITY MARKED BY ALLŌS}

In the Metaphysics $\Delta 25$ Aristotle distinguishes four ways ${ }^{2}$ in which something is called a part: 
(1) a part is the result of a division of a quantity, the division being either arbitrary or giving measure, as two is an arbitrary part of three, but not a part which gives measure of three;

(2) parts are the results of a non-quantitative division of a form (i.e. of a genus, namely, a form having forms below itself), as the form, along with other forms, is a part of the genus (to eidos tou genous meros);

(3) parts are the results into which a whole is divided or the constituents out of which it is composed, as both matter and form are parts of something that has the form;

(4) parts are the constituents of a formula (and thus of the form), as the genus (along with the differentia) is a part of the form (to genos tou eidous meros).

Aristotle stresses the difference between the fourth and the second way in which something is called a part by saying that a genus is also called a part of its form, although in a different way the form is a part of its

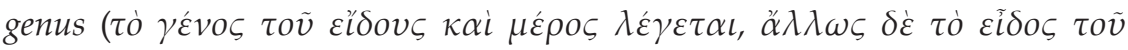

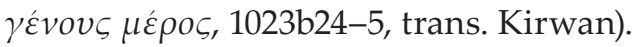

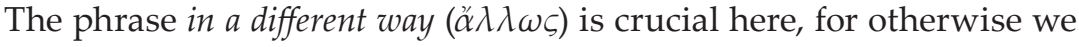
slip into absurdity. This slip can be easily demonstrated if we assume this principle:

Antisymmetry of Parthood: Two entities which are part of each other are identical.

Let us omit the phrase in a different way and suppose that, unqualifiedly, the genus is a part of the form and the form is a part of the genus. By the Antisymmetry of Parthood, it follows that, if the genus is a part of the form and the form is a part of the genus, then the genus and the form are identical. This result is alarming, since Aristotle would not admit that the genus and the form are identical. It would amount to saying that animal (genus) is identical to man (form). Hence it is not the case that, unqualifiedly, the genus is a part of the form and the form is a part of the genus. If the genus and the form must be distinct and simultaneously it is true that both the genus is a part of the form and the form is a part of the genus, then it must be the case that the genus and the form are parts of each other in a different way.

At first glance, the most evident variant how to interpret the phrase in a different way, viz. the difference between (2) and (4), is to assume that the meaning of genos and eidos shifts. Namely, genos in (2) expresses a 
distinct concept than genos in (4), and likewise eidos in (2) expresses a distinct concept than eidos in (4). In other words, genus containing the form as a part is distinct from genus being a part of the form, and, similarly, form being a part of the genus is distinct from form containing the genus as a part.

It can still be the case that the referents of genos and eidos in (2) and in (4) do not change, although the meaning does, i.e. the extension remains the same, despite varying intensions. The extensionalistic reading can be adopted with the proviso that the referents of genos and eidos are universals, e.g. animal and man, since Aristotle remarks that the forms as parts of the genus result from a non-quantitative division (1023b17), which suggests that he is not talking about a set of particulars. The constancy of extension, viz. the idea that the genus in (2) is the same universal as the genus in (4), is compatible with the variability of intensions, viz. the idea that the concept of genus in (2) differs from the concept of genus in (4). The same consideration applies to the form.

But what happens to the concept of part? Does meros both in (2) and in (4) preserve the same meaning? It is argued in this article that it does not. Moreover, it is shown that the distinct concepts of genus and form hinge on the distinct ways something is called a part, and there are distinct meanings of part, because meros expresses different relations of parthood.

It has to be emphasized that part is a predicate expressing a relational attribute $(\pi \rho o ́ \varsigma \tau \iota)$, viz. a part does not stand on its own; a part is a part of a whole, just as a slave is a slave of a master and a master is a master of a slave (Cat. 7, 6b29-30). It means that an object which is called a part stands in a relation of parthood to something of which it is a part. Thus, meros does not primarily refer to an object which is called a part; more importantly, meros expresses the relation of parthood in which that object stands. The author of the article claims that for Aristotle there are several such relations of parthood.

In contrast to genos (and to eidos) which has different meanings despite having the same referent, meros has different meanings due to expressing distinct relations of parthood.

\section{THE AMBIGUITY OF MEROS}

The general purpose of Book $\Delta$ of the Metaphysics is to list the meanings of various philosophically significant terms. The collection 
of these meanings constituting Book $\Delta$ is referred to by Aristotle as $\tau \dot{\alpha}$

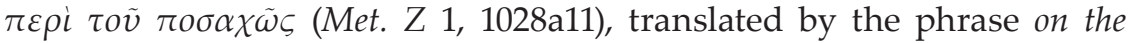
number of ways in which things are said (Furth 1985). ${ }^{3}$ Chapter 25 of Book $\Delta$ presents a list of the many ways something is called a part. If Aristotle is taken at his word, distinct entries on the list should indeed be distinct. The reason for setting apart one meaning of meros from another must be grounded in the realization that the nature of parthood is multiplex. By distinguishing the meanings of meros Aristotle proposes the idea that objects called parts are not tied together by a single relation of parthood. Instead, there are various relations of parthood, where each operates according to its own principles and has its own properties. It is assumed here that two relations of parthood are identical if and only if they have the same properties.

By contrast, there is a view that one should avoid postulating a variety of relations of parthood, as it leads to an undue proliferation of them (Koslicki 2008, 158; cf. 2007, 138-9). The ambiguity of meros overthrows the conceptions of parthood, where the two-place predicate part of operates according to a fixed set of principles and thereby is essentially univocal. The ambiguity of meros, then, seems to be less elegant due to the lack of parsimony.

However, if it turns out that the relata do not change, while the relation itself does, the proliferation of the relations is compensated by the reduction of the number of objects to which these relations apply. It is conceivable that the genus and the form remain the same objects, i.e. universals, while the relation of parthood in which they stand varies. In other words, the relata of the parthood relation preserve their identity; what differs is the relation is a part of: $A$ is a part of $B$, and $B$ is a part ${ }_{2}$ of $A$. This does not exclude the idea that different concepts could correspond to the same object in different relations. For instance, genus as containing the form as a part and genus as being a part of the form are different concepts, while genus as such remains the same object.

\section{THE MEANINGS OF GENOS AND EIDOS}

Both genos and eidos are said in many ways. ${ }^{4}$ We are interested in those meanings, as Porphyry puts it when explaining Aristotle's term genos, which are of account to philosophers (Isag. 2.14-15, trans. Barnes). First of all, this account requires acknowledging that eidos and genos are 
correlates - the one does not make sense without the other. ${ }^{5}$ If there is a genus, it is a genus of a form, and if there is a form, it is a form of a genus, unless this form itself is the highest genus. Every genus has a form above or below itself, and every form has a genus above or below itself. ${ }^{6}$

The correlative nature of genos and eidos presupposes that the meaning of the one determines the meaning of the other and vice versa. If genos and eidos have several meanings, these also have to be mutually determined. We do not have to look far for the right specification of the meanings of genos and eidos, since the meanings of meros already give us a hint.

According to the list (1)-(4) in Met. $\Delta 25$, the meaning of genos in (2) to eidos tou genous meros corresponds to Aristotle's account in the Topics A 5, 102a31-2, which is quoted verbatim in Porphyry's Isagoge 2.16-17: a genus is what is predicated, in answer to 'What is it?', of several items which differ in species [i.e. form - $\varepsilon i \delta o \zeta]]^{7}$ for example, animal (trans. Barnes). Porphyry also remarks (ibid. 2.10-13) that we call a genus that under which a species [i.e. form] is ordered (trans. Barnes).

By keeping in mind that genos and eidos are correlates, the appropriate meaning of eidos in (2) is immediately determined. Aristotle talks about the form as being under a genus (Top. E 4, 133b10); he says that the form is a subject for the genus and the genus is predicated of it (Cat. $5,2 \mathrm{~b} 19-20)$. This is manifested in one of the accounts of eidos given by Porphyry as what is ordered under a genus; and: that of which a genus is predicated in answer to 'What is it?' (Isag. 4.10-11, trans. Barnes).

The meaning of genos in (4) to genos tou eidous meros in Met. $\Delta 25$ corresponds to the meaning of genos in $\Delta 28,1024 \mathrm{~b} 4-5$ as the first constituent in formulae which is stated in [answer to the question] what a thing is (trans. Kirwan), e.g. the genus animal is stated in answer to what is, for example, man or horse. In this sense, genus is as matter ( $\omega \varsigma$ vँ $\lambda \eta$, Met. $\Delta 28$, 1024b8-9) of its differentia, which, together with the genus, makes up the form. Genus is not exactly hule but only hōs hule, for matter strictly speaking belongs to form-matter composites, which is (3) on the list in Met. $\Delta 25$.

Accordingly, the meaning of eidos in (4) is apparent when the form is treated as the object of definition. Since the formula of the form is out of genus and differentia (Top. Z 6, 143b19-21), and as the formula is to the thing, so the part of the formula is to the part of the thing (Met. Z 10, $1034 b 21-2$, trans. Furth), hence also the form itself is out of genus and 
differentia (Met. I 7, 1057b7). Thus, the meaning of eidos in to genos tou eidous meros is what comprises the genus, together with the differentia, as a constituent. ${ }^{8}$

The meanings of genos and eidos in (4) are linked to those in (2), since the referents of genos and eidos in (4) are the same as those in (2). It can be seen via the relations of predication that obtain in both cases. As in (2), so in (4), the genus is predicated of the form, ${ }^{9}$ whereas the form is not predicated of the genus (Cat. 5, 2b20-1). It is correct to predicate animal of man and to say that every man is an animal, but it is incorrect to predicate man of animal and to say that every animal is a man (Porph. Isag. 7.6-8).

\section{THE RELATIONS OF PARTHOOD}

To say that the genus is a part of the form in a different way than the form is a part of the genus is to stress that $A$ is a part of $B$ in a different way than $B$ is a part of $A$. What needs to be explained is the difference between these ways of being a part.

The most straightforward explanation is the following: when the genus is a part of the form (to genos tou eidous meros), the genus composes $(\sigma \dot{v} \gamma \kappa \varepsilon \iota \tau \alpha \iota)$ the form along with the differentia, but when the form is a part of the genus (to eidos tou genous meros), the genus is merely divided

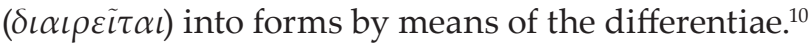

The underlying feature behind a part's capacity of composing a whole, as opposed to being solely the result of a division of a whole, is its independence from the whole, i.e. ability to exist without the whole. The parts of the form compose the form, because they are independent of the form. The genus animal can exist without the form man, that is, no animal has to be a man. However, the parts of the genus do not compose the genus, because the parts are dependent on it. The form man cannot exist without the genus animal, that is, no man can fail to be an animal. ${ }^{11}$

This reflects a crucial difference in properties of the relation of parthood expressed by meros in (2) and in (4) on the list in Met. $\Delta 25$. That is to say, meros in (4) to genos tou eidous meros expresses a relation of parthood where the parts compose the whole, i.e. the parts are independent of the whole and the whole is dependent on them, whereas meros in (2) to eidos tou genous meros expresses a relation of parthood where the parts 
only divide the whole and do not compose it, i.e. the parts are dependent on the whole and the whole is independent of them.

\section{CONCLUDING REMARKS}

It has been shown that the statement in Aristotle's Metaphysics $\Delta 25$, $1023 \mathrm{~b} 24-5$ that the genus is a part of the form in a different way than the form is a part of the genus has to be interpreted in light of the phrase in a different way, which, instead of merely relating it to a change in the meaning of genos and of eidos, has to be tied with a shift in the meaning of meros, which, in turn, relies on the distinction between relations of parthood.

The idea that it is meros that is ambiguous has at least two farreaching implications. Firstly, it has implications for the interpretation of Aristotle's theory of parts and wholes. If meros in to genos tou eidous meros differs in meaning from meros in to eidos tou genous meros, then one should rightly ponder whether similar considerations apply to the other ways in which something is called a part in $\Delta 25$, and moreover, one should be cautious of ambiguity with occurrences of meros in other contexts. Secondly, the ambiguity of meros suggests that the understanding of other ambiguous terms listed in Book $\Delta$ of the Metaphysics requires more intricate appreciation of their complex nature, which in turn demands aspirations towards an unbiased reading of the text.

\section{REFERENCES}

1 The meaning of meaning stated here is formulated by Putnam (1994, 222-5) as the traditional doctrine, which he deems unsatisfactory. In spite of his criticism, this doctrine will do as a crude tool for the purposes of this article.

2 The classification of the Aristotelian meanings of part given in Met. $\Delta 25$ under four headings is taken from Aquinas (In Met. lib. 5 1. 21 n. 9). Ross (1958, vol. 1, 339) also gives a fourfold classification. However, for instance, Kirwan $(1971,60)$ and Koslicki $(2007$, 134-5; 2008, 139; cf. 2006, 718 n. 10) distinguish five meanings of part, since they sort the two ways of dividing a quantity into separate entries.

3 Besides $\tau \dot{\alpha} \pi \varepsilon \rho \dot{i} \tau o \tilde{v} \pi o \sigma \alpha \chi \tilde{\omega} \varsigma$, Ross (1958, vol. 1, xxv) mentions $\dot{\varepsilon} v$ ä $\lambda \lambda o \iota \varsigma$ (see, e.g. $1017 \mathrm{~b} 9 ; \Theta 1,1046 \mathrm{a} 5-6)$ as Aristotle's way of referring to the contents of Book $\Delta$. Furth (1985) renders ćv ä $\lambda \lambda$ oı in 1046a5-6 simply as elsewhere.

4 There is no list of the meanings of eidos, whereas in Met. $\Delta 28$ we can find a list of the meanings of genos, which, however, does not include all the meanings of genos used by Aristotle.

5 Aristotle does not explicitly say that genos and eidos are correlates, but this idea can be derived from his talk about relatives $(\tau \dot{\alpha} \pi \rho o ́ \varsigma \tau \iota)$ in Book 7 of the Categories. 
6 The highest genus is not a form of a genus above itself, and the last form is not a genus of a form below itself; the intermediate genera are forms of the highest genus and genera of forms below them (see Porph. In Cat. 83.20-3).

7 It is traditionally accepted that $\varepsilon \dot{\delta} \delta o \varsigma$ in Aristotle is translated by two names, i.e. form or species, depending on the context of use. In the context where the relations of $\varepsilon i \delta o \varsigma$ and $\gamma \varepsilon \dot{v} v o \zeta$ are operative, the rendering of $\varepsilon i \delta o \varsigma$ is species, whereas form as a translation of $\varepsilon i \delta o \varsigma$ is used to contrast it with matter ( $\dot{v} \lambda \eta)$ when talking about form-matter composites. This brings out the affinity of $\varepsilon i \delta o \varsigma$ to $\mu о \rho \phi \eta$ - shape or appearance. From time to time Aristotle employs $\mu о \rho \phi \eta$ to designate the formal aspect of form-matter

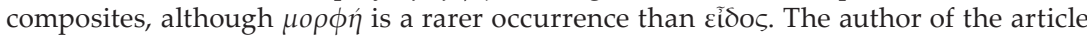

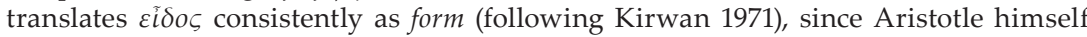
uses عiٓठos in both contexts.

8 It is not uncontroversial whether genus literally is a constituent of the form. Koslicki (2006, 728 n. 32; cf. 2008, 158) rightly points out that form should not be identified with definition (of which genus is a constituent), since a definition is a linguistic entity, whereas a form is what is described by it. At the same time, it cannot be denied that Aristotle endorses correspondence between the parts of the definiens, i.e. the terms of the definition, and the parts of the definiendum (Met. Z 10, 1034b21-2). In that case, there is no way to circumvent the fact that something in the form, i.e. a constituent of the form, is picked out by each term of the definiens. Since a form is delimited within a genus by a differentia, there is no reason why one should not concede that in a way the form consists of genus and differentia.

9 In fact, both constituents of the form can be predicated of the form. The differentia can be predicated of the form, e.g. rational can be predicated of man, when the differentia

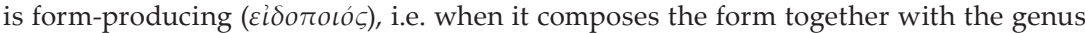
(Top. Z 6, 143b8-9). However, the differentia cannot be predicated of the form, when it serves to divide the form (qua genus) into subordinate forms, e.g. rational cannot be predicated of animal, for animal is not composed as a form by the differentiae that divide it (see Porph. In Cat. 85.21-8).

10 The same idea is voiced also in Boethius' De Divisione 39.1-2 when it is stated that in division the genus is a whole, in definition a part (trans. Magee). What is emphasized is that definition resembles the composition of a whole (ibid. 39.5, trans. Magee), it is as if parts of some kind are constituting a whole (ibid. 39.2-3, trans. Magee), namely the form (i.e. species in Boethius' terminology, 39.20), but in division the whole, namely the genus, is merely resolved into parts. In Medieval terminology (see, e.g. Aquinas In Met. lib. 5 1. 21 n. 13), a genus having the form as a part is a universal whole (totum universale) predicated of its form as of a subjective part (pars subiectiva), whereas a genus being a part of the form is, along with the differentia, an integral part (pars integralis) of the form, which in this case is an integral whole (totum integrale).

11 The dependence of the parts on the genus and the independence of the genus from its parts are affirmed also in De Div. 13.36-14.1: [I]f the genus is destroyed the species immediately perish, but ... if a species is destroyed the genus consists inviolate in its nature (trans. Magee).

\section{BIBLIOGR APHY}

Aristotelis categoriae et liber de interpretatione. L. Minio-Paluello (Ed.). Repr. Oxford : Clarendon Press, 1966.

Aristotelis topica et sophistici elenchi. W. D. Ross (Ed.). Repr. Oxford : Clarendon Press, 1970. 
Barnes, Jonathan. Porphyry's Introduction, Translated with a Commentary. Oxford : Clarendon Press, 2003.

Furth, Montgomery (Trans.). Aristotle, Metaphysics, Books VII-X, Zeta, Eta, Theta, Iota. Indianapolis : Hackett Publishing Company, 1985.

Kirwan, Christopher. Aristotle, Metaphysics, Books Gamma, Delta, and Epsilon, Translated with Notes. Oxford : Clarendon Press, 1971.

Koslicki, Kathrin. Aristotle's Mereology and the Status of Form. Journal of Philosophy, 103 (12), 2006, 715-36.

Koslicki, Kathrin. Towards a Neo-Aristotelian Mereology. Dialectica, 61 (1), 2007, 127-59.

Koslicki, Kathrin. The Structure of Objects. Oxford : Oxford University Press, 2008.

Magee, John. Anicii Manlii Severini Boethii De Divisione liber: Critical Edition, Translation, Prolegomena, and Commentary. Leiden, Boston, and Köln : Brill, 1998.

Porphyrii isagoge et in Aristotelis categorias commentarium. A. Busse (Ed.). Vol. 4, bk. 1 of Commentaria in Aristotelem Graeca. Berlin : Reimer, 1887.

Putnam, Hilary. The Meaning of 'Meaning'. R. M. Harnish (Ed.). Basic Topics in the Philosophy of Language. Upper Saddle River, NJ : Prentice-Hall, Inc., 1994, 221-74.

Ross, William D. Aristotle's Metaphysics, a Revised Text with Introduction and Commentary. 2 vols. Repr. of 1953 corr. edn. Oxford : Clarendon Press, 1958.

S. Thomae Aquinatis In duodecim libros Metaphysicorum Aristotelis expositio. M. R. Cathala, R. M. Spiazzi (Eds.). 2nd ed. Taurini-Romae : Marietti, 1971.

Lìva Muižniece, Latvijas Universitāte, Latvija

TO GENOS TOU EIDOUS MEROS UN TO EIDOS TOU GENOUS MEROS NOZĪME ARISTOTEL̨A METAFIZIKĀ $\triangle 25$

Aristotelis Metafizikā $\Delta$ 25, 1023b24-5 pretstata to genos tou eidous meros un to eidos tou genous meros, sakot, ka gints ir veidola daļa citādi (allōs) nekā veidols ir gints daḷa. Raksta autore aizstāv domu, ka pretstatījums, ko iezīmē citādi, atklāj divas atšķirīgas daļas nozīmes, kas katrā no gadījumiem nosaka gints un veidola nozīmes un izsaka atškirīigu daḷas attiecību (relation of parthood). Daḷas nozīme izteikumā gints ir veidola dalı paredz, ka ǵints jāsaprot kā veidola noteiksmes un arì paša veidola pirmā sastāvdaḷa lìdzās atšķirībai (differentia) un kā viela, bet veidols kā veselums, kas ir salikts no gints un atšķirības. Arī daļas nozīme izteikumā veidols ir gints daļa nosaka nozīmi gintij un veidolam: gints ir tā, kas tiek apgalvota par veidolu kā par pamatu, bet veidols ir tas, kas tiek pakārtots gintij. Daḷa izteikumā gints ir veidola daḷa izsaka tādu daḷas attiecību, kur daḷas nevis sadala, bet gan saliek veselumu, t. i., daḷas ir neatkarīgas no veseluma, un veselums ir atkarīgs no tām, turpretī daḷa izteikumā veidols ir ǵints daḷa izsaka tādu daḷas attiecību, kur daḷas tikai sadala veselumu un to nesaliek, t. i., daḷas ir atkarīgas no veseluma, un veselums ir neatkarīgs no tām. 


\section{LĪVA BODNIECE}

Latvijas Universitāte, Latvija

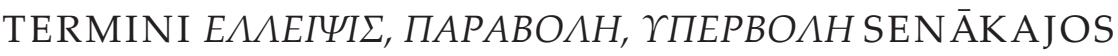 RĒTORIKAI UN ĢEOMETRIJAI VELTĪTAJOS TEKSTOS}

\section{İss kopsavilkums}

Elipse, parabola, hiperbola ir mūsdienu zinātnes valodas termini, tie funkcionē gan humanitāro zinātņu, gan dabaszinātņu terminoloǵijā, līdzīgi tie tikuši lietoti jau ap 6. gs. p. m. è.

Vērošana un novērojumu pierakstīšana bija pirmais solis zinātniskās literatūras attīstībā. Starp jēdzieniem redzēt un zināt sengrieḳu valodā pastāv lingvistiska saikne. Zināt var to, kas ir redzēts savām acìm. Redzētā aprakstīšanai izmantoti salīdzinājumi ar dabā un sadzīvē vērojamām norisēm, tas palīidz abstraktus jēdzienus padarīt saprotamus. Šis pan̄ēmiens tiek izmantots terminu veidošanā arī mūsdienās.

Atslēgvārdi: elipse, hiperbola, parabola, rētorika, ǵeometrija, terminu veidošana.

Sengrieḳu un latīṇu valodas leksēmas un no jauna veidoti seno valodu morfēmu savienojumi tiek izmantoti mūsdienu zinātnes valodas terminu veidošanā dažādās nozarēs. Turklāt daudzi no tagad lietotajiem terminiem atrodami jau pašos senākajos tekstos. Attīstoties zinātniskās valodas stilam un veidojoties arvien jaunām zinātṇu nozarēm, main̄̄jušies terminu apzīmētie jēdzieni un to izpratne, tomēr ir piemēri, kad termins un tā apzīmētais jēdziens palicis nemain̄̄gs cauri gadsimtiem.

Attīstoties saimniecībai un kultūrai, radās nepieciešamība notiekošo aprakstīt. Lai kaut ko aprakstītu, tas labi jāiepazīst - jānovēro. Vērošanas procesam ir liela nozīme sengrieḳu zinātniskās domas attīstībā. Vērošana no vienkāršas skatīšanās atšķiras ar to, ka vērojumi liek vērtēt un izdarīt secinājumus.

Lìdz mūsu dienām nonākušas ziņas un pat saglabājušies vērā ņemami fragmenti no apmēram 5. gs. p. m. ē. tapušiem sacerējumiem. Šie pirmie, par zinātniska satura tekstiem uzskatāmie avoti atklāj autoru vērojumus un izdarītos secinājumus par dabas parādībām un procesiem. No pieejamā tekstu materiāla un informācijas par zudušajiem darbiem ir zināms, ka vērojumu loks bijis plašs - sākot ar dabas procesu 
vērojumiem līdz dažādu prasmju ( $\tau \dot{\varepsilon} \chi v \eta)$ un atklājumu aprakstī̌sanai. ${ }^{1}$ 5. gs. p. m. è. jau bija aprakstītas ǵeometriskās figūras un sakarības tajās, bija formulētas teorēmas, piemēram, Pitagora, Talēta teorēma utt.

Pievēršanās kādu procesu vai parādību vērošanai sniedz informāciju par notiekošo un liek izdarīt secinājumus - ar to vērošana atšķiras no pasīvas notikumu vai procesu aplūkošanas jeb vienkāršas redzēšanas acu priekšā. Vērojums ir izziṇas procesa sastāvdaḷa - parādības vai notikumu aplūkošana ar mērḳi iepazīt un izdarīt secinājumus no redzētā. Iepriekšējiem vērojumiem, spriedumiem un secinājumiem ir liela nozīme jaunu secinājumu izdarī̌sanā.

Jēdzienu vērot un zināt ciešo saikni sengrieķu pasaules uztverē uzskatāmi demonstrē arī lingvistiskais aspekts to apzīmēšanā. Apzīmējumi jēdzieniem redzêt un zināt sengrieḳu valodā radušies no darbības vārda ó $\rho \alpha ́ \omega$.

óów (verb. 1. p. praes. ind. act.) - es redzu ar acim (tagadnes forma)

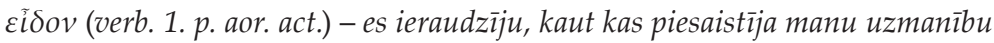

(pabeigtības nozīme)

oíd $\alpha$ (verb. 1. p. 2. pf.) - es zinu / esmu ieraudzījis (2. perfekts ar tagadnes nozīmi) (Liddell, Scott, Greek-English Lexicon)

Šis formu veidošanas piemērs uzskatāmi parāda, kā atkarībā no darbības laika jēdzieniski mainās vārda nozīme. Ja kaut kas, ko redzam, piesaista uzmanību, liek izdarīt spriedumus, tad šajā mirklī vienkārša redzēšana pārtop novērošanā, pēc kāda laika vērotājam rodas secinājumi, kas apkopoti kḷūst par zināšanām. To, kas ir acīm redzams - atrodas acu priekšā, ir iespējams novērot un līdz ar to arī iepazìt. Redzamais ir ticams. Šāds skatījums pamato antīkajos zinātniskajos tekstos izmantoto paṇēmienu - aprakstot savus vērojumus, lietot salīdzinājumus ar citām acīm redzamām, bieži sadzīviskām parādībām. Paṇēmiens ir īpaši noderīgs, ja jāapraksta parādības, kas nav ar acìm redzamas; salīdzinājumi ar acìm redzamo kalpo par izskaidrojumu acìm neredzamām parādībām.

Vērošanas procesam un salīdzinājumam ar acìm redzamo ir paliekoša nozīme zinātṇu terminu veidošanas principu attīstībā. Arī mūsdienu zinātṇu terminologiijas veidošanā redzam šo pašu principu - salīdzināt ar to, kas ir zināms. Termins, kas nosauc jēdzienu, piemeklēts, pamatojoties uz līdzību ar kādu zināmu parādību.

Kaut arī dabā ir daudz procesu un parādību, kurus iespējams izmantot metaforisku salīdzinājumu veidošanā, divās pirmajā mirklī šķietami 
nesaistītās zinātṇu nozarēs - rētorikā un geometrijā - ienāk un nostiprinās termini, kas atvasināti no darbības vārdiem; šie termini ir elipse, parabola, hiperbola. Visi trīs termini turpina funkcionēt minētajās zinātnes nozarēs līdz pat mūsu dienām.

Ģeometrijas zinātnē šie termini apzīmē konusa šḳēlumus. Rētorikā mākslinieciskās izteiksmes līdzekḷus. Abās zinātnēs šie lielumi tiek saukti par figūrām, veidoliem (figurae, $\sigma \chi \eta \dot{\eta} \mu \alpha \tau \alpha$ ).

Hipotēze - šāda vārdformu izvēle nav nejauša, tomēr ir pamats uzskatīt, ka jēdzienu formulējumi nav ienākuši ǵeometrijas terminologiijā tieši no rētorikas. Termini abās zinātnēs veidojušies no vērojumiem ar līdzīgiem secinājumiem, kuru izteikšanai noder darbības vārdi ar vairākām atvasinātām nozīmēm.

Ģeometrijas zinātne pēta geometrisko figūru īpašìbas un savstarpējās sakarības, novietojumu, mūsdienās tai tiek nodalītas vairākas apakšnozares. Viens no rētorikas uzdevumiem ir pētìt rētorisko figūru attiecības tekstā. Abas zinātnes vieno elementu attiecību pētìjumi. Apskatāmie termini konkrētajās zinātnēs apzīmē elementus. Šo elementu funkcijas minētajās zinātnes nozarēs ir raksturojamas ar terminu veidošanā izmantotajiem darbības vārdiem.

Pirmais mums zināmais avots, kurā konusu šḳēlumi apzīmēti ar

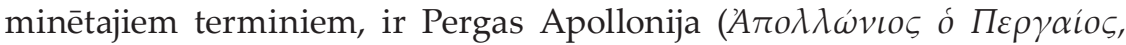

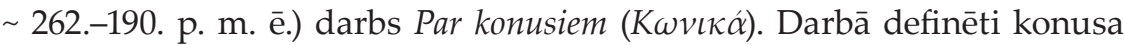
šḳēlumi un aprakstītas to īpašības. Nosaukumi izraudzìti, ņemot vērā figūru īpašības un attiecības vienai pret otru. Liela nozīme terminu veidošanā ir skaidrojumam, kā konusa šḳēlumus attēlot plaknē. ${ }^{2}$

- $\pi \alpha \rho \alpha \beta o \lambda \eta \dot{\eta}, \dot{\eta}-$ parabola

Darbības vārds $\pi \alpha \rho \alpha \beta \alpha \dot{\lambda} \lambda \omega-$ nolikt malā, uzlikt, pārlikt

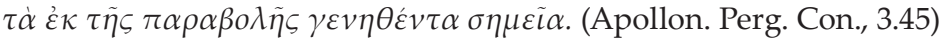

tā, no parabolas [uzlikšanas] radusies atzìme [punkts].

Parabola ir līkne, kuras katrs punkts atrodas vienādā attālumā no fokusa un direktrises, kas ir fiksēti attālumi, tā var tikt uzlikta jebkurā vietā koordinātu asij.

Apskatot elipses un hiperbolas jēdziena skaidrojumus, var secināt, ka arī tie izteikti pēc novērojumiem konusa šḳēlumu attēlošanai plaknē.

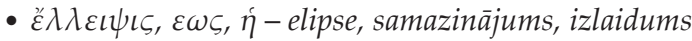

Darbības vārds $\lambda \varepsilon i$ ic $\omega$ - pamest, atstāt

LXIX 
- $v \pi \varepsilon \rho \beta o \lambda \eta \dot{\eta}$, -hiperbola, palielinājums

Darbības vārds $v \pi \varepsilon \rho \beta \dot{\alpha} \lambda \lambda \omega$ - aizmest tālumā, pārmest pāri, palielināt

Samazinājums vai palielinājums ieraugāms attiecībā pret lielumiem uz abscisu un ordinātu ass.

Rētorikas terminologijāa šìs leksēmas izmantojis Aristotelis

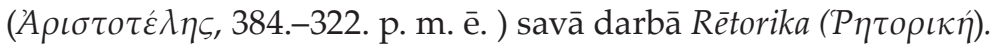

- $\pi \alpha \rho \alpha \beta o \lambda \eta \dot{\eta}, \dot{\eta}$ - parabola - ilustratīos salīdzinājums, piemērs no dzīves, arī ievietošanas nozīmēe, jo par piemēru minètais stāsts tiek it kā ielikts stāstījumā

Aristotelis, paskaidrojot parabolas jēdzienu, to ilustrē ar piemēru:

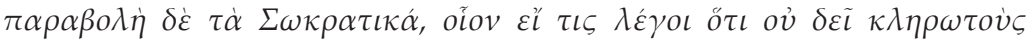

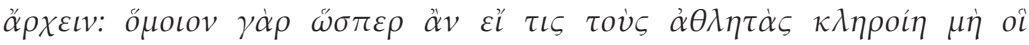

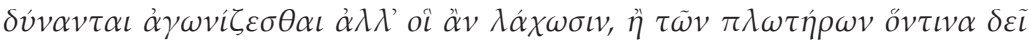
$\kappa v \beta \varepsilon \rho v \tilde{\alpha} v \kappa \lambda \eta \rho \omega ́ \sigma \varepsilon \iota \varepsilon v, \omega \varsigma \zeta \delta \dot{\varepsilon} \sigma v \tau \dot{o} v \lambda \alpha \chi \dot{v} v \tau \alpha \dot{\alpha} \lambda \lambda \dot{\alpha} \mu \dot{\eta} \tau \dot{o} v \dot{\varepsilon} \pi \iota \sigma \tau \alpha \dot{\alpha} \mu \varepsilon v o v$. (Arist. Rh., 2.20.4)

Parabola ir sokratiskie izteicieni, piemēram, ja kāds teiktu, ka valdītājus nevajag izlozēt, jo lìdzīgi būtu, ja kāds izlozētu sacensību dalībniekus un tie būtu nevis tie, kuri ir spējīgi sacensties, bet kuriem izkrìt loze, vai ja izlozētu to kuǵinieku, kuram jāvada kuǵis, it kā to vajadzētu darìt izlozētajam, nevis zinošajam.

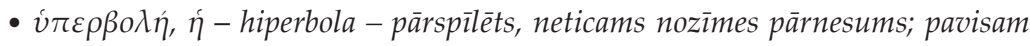
neliela ir atškirība starp hiperbolu un metaforu, metafora ir lìdzība, hiperbola pārspīlējums uz lìdzìbas pamata

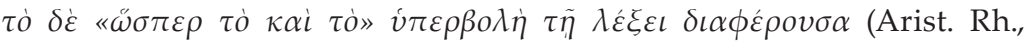
3.11.15)

kādā veidā "tas un tas" ir pārmēerība, tas atšķiras pēc izteiksmes (izteiksme nosaka to, kad vienkāršs nozìmes pārnesums ir pārspīlējums).

- $\varepsilon \lambda \lambda \varepsilon \iota \psi \iota \varsigma, \varepsilon \omega \varsigma, \dot{\eta}$ - elipse - izlaidums, iztrūkums, pretējs hiperbolai

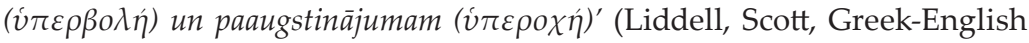
Lexicon)

Rētorikas teksts ir senāks par Apollonija Par konusiem, iespējams, tāpēc terminu paskaidrojumi Aristoteḷa tekstā ir literārāki, viņš tekstā lieto piemērus. Izteiksme pamatojama arī ar to, ka Aristoteḷa apskatītie

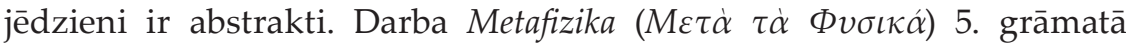


autors skaidro filozofijas terminus un pamato, kādu jēdzienu apzīmēšanai šie termini tiek lietoti. Jēdzienu skaidrošanai tiek izmantoti ilustratīvi apzīmējumi ar ikdienā vērojamiem procesiem. Piemēram, paskaid-

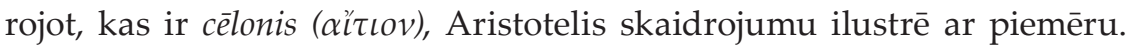

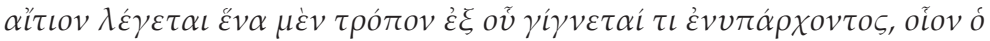

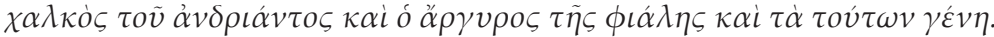
(Arist. Met., 5. 1013a)

cèlonis nozìmē to, no kā kaut kas rodas, kā statujai tas (cēlonis, pirmsākums) ir bronza un kausam sudrabs.

Apollonijs savus formulējumus izsaka l̦oti koncentrēti, skaidrojot, kas pret ko attiecas un kur atrodas; geometrijas zinātṇu aprakstī̌sanai

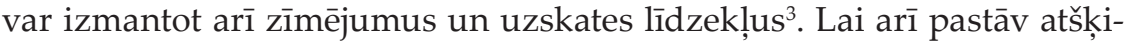
rības vēstījuma izteiksmes veidā, nevar noliegt, ka principi, pēc kādiem aprakstu formulējumi veidoti, ir līdzīgi.

Pamatojoties uz atklājumiem gan rētorikā, gan geometrijā, vēlākajos gadsimtos nākuši klāt jauni termini. Tomēr jēdzieni un aprakstǐšanas veids palikuši nemainīgi. Jauns aprakstāmais lielums tiek izteikts no zināmā. Piemēram, taisnstūris ir paralelograma speciāls gadījums, kam visi leṇki ir taisni.

Atzīmēšanas vērts ir novērojums, ka gan Arsitotelis Rētorikā, gan autori vēlāko laiku tekstos (Kvintiliāns, Cicerons), skaidrojot un aprakstot iepriekš minētās rētorikas figūras, izmanto piemērus no zināmiem literāriem darbiem - ilustrācijas, tas ir līdzīgi kā zīmējumi geometriskajos tekstos ${ }^{4}$. Piemēram Kvintiliāns (Marcus Fabius Quintilianus, 35.-100. m. ē.) darbā Oratoru audzināšana (Institutio Oratoria) kādu savu argumentu pamato ar piemēru no Cicerona:

Est interim certa finitio, de qua inter utramque partiem convenit: ut Cicero dicit - Maiestas est in imperii atque in nominis populi Romani dignitate.

Mèdz būt arī noteikti izteikumi, kas noderīgi abām pusēm, kā saka Cicerons Diženums ir impērijā un arī Romiešu tautas cildenumā.

Tiek ievērots princips skaidrot terminu ar acīm redzamo, šajā gadījumā - zināmo, lasīto, dzirdēto. Ģeometrijas zinātne ir acìm redzamāka, tāpēc noder kā lielisks salīdzinājums rētorikas acìm neaplūkojamajiem 
lielumiem, un tādēl ir likumsakarīgi, ka mūsdienās visdažādāko nozaru oficiālajā terminologijā un arī profesionālajā žargonā gadījumos, kad jāapraksta abstrakti jēdzieni, tiek lietoti ǵeometrijas termini: finanšu piramìda, drāmas trīsstūris utt.

Renesanses laikā aktuālās antīkās pasaules kultūras un zinātnes mantojuma studijas pavēra zinātniskās terminologijas līdzības filozofiskam skatpunktam. Vēlās renesanses pārstāvis Džordano Bruno uzskatìja, ka visas zinātnes ir savstarpēji saistītas un nav nodalāmas viena no otras, turklāt arī vēstījuma formai, kādā tās atklātas, jābūt tādai, lai visi teksta izteiksmes līdzekḷi kalpotu satura atklāsmei. Viduslaiku un renesanses literatūras un filozofijas pētniece Ariela Saibere (Arielle Saiber) nodarbojusies ar Džordano Bruno darbu pētījumiem un monogrāfijā Džordano Bruno un valodas geometrija (Giordano Bruno and the Geometry of Language, 2005) apkopojusi Bruno atziņas no darba Lielā gavēņa pirmās dienas vakarēšana (La Cena de le ceneri, 1584). Bruno piemin elipsi, hiperbolu, parabolu, turklāt tās skaidro gan kā retoriskus, gan geometriskus lielumus, nojaucot robežu starp zinātnēm.

- $\quad$ Elipse

Konceptuāla atškirīiba šḳir geometrisko un rētorisko elipsi. Rētoriskā elipse apzīmē gan tukšumu, gan šo izlaisto vārdu/jēdzienu un ietver sevī samazinājumu un neierobežotību, turpretī geometriskā elipse, kas ir norobežota figūra, ietver sevī samazinājumu un ierobežotību. Abām kopīgs ir tas, ka tās apzīmē sava veida trūkumu.

Elipses trīs punkti ir tukša solījuma simbols. Elipse reizē ir tukša, jo izstumj vārdu, bet reizē pilna - jo tai ir izstumtā vārda potenciāls.

- Hiperbola

Hiperbola ir konusa sekcija, līkne ar diviem simetriskiem zariem un diviem fokusiem, tā rodas, sašḳeḷot konusu. Tai piemīt ekscentriskums fokusa attālums līdz sekcijas punktam un abscisu asij.

Elipse ir izlaidums, tam pretstatītais amplificatio ir pieaudzējums, daudzvārdība. Hiperbola - pārspīlējums, savā ziņā arī tas ir pieaudzējums. Mākslinieciskās izteiksmes līdzekḷi hiperbola un elipse var būt pretēji viens otram; arī matemātiski tos iespējams izteikt vienu caur otru (Saiber 2005, 120-127).

Ir pamatoti uzskatīt, ka senākajos ǵeometrijas un rētorikas tekstos izmantotie figūru apraksti atstājuši iespaidu uz vēlāku laiku un, protams, mūsdienu zinātniskajā valodā lietoto izteiksmes veidu. 
Ģeometrijas zinātnei piemītošais vizuālais potenciāls zinātnes un izglìtības attīstības gaitā ir transformējies, kḷuvis par zināmo - tas ir redzèts savām acìm, novērots un izpētīts.

Tāpēc, runājot par rētorikas figūru definīcijām mūsdienu zinātniskajā literatūrā, geometrisku lielumu un attiecību piesaukšana tiek lietota kā atsaukšanās uz acīm redzamo, zināmo. Piemēram, paralēlisms - divu parādību līdzās nostatījums, kas izceḷ tajās līdzīgo vai atšḳirīgo; vai arī hiperbola ir vertikāla metafora, ja metaforu saprot kā horizontālu. Metafora savieno lietas, kurām ir viens horizonts, kamēr hiperbola tiecas savienot lietas, kas atrodas dažādos augstumos (Webb 1991, 88).

Salīdzinājumi un atsauces uz geometrijas zinātnes acìm redzamajiem objektiem palīiz attēlot rētorikas acìm neredzamos lielumus.

\section{ATSAUCES}

1 Par pirmajiem grieḳu zinātniekiem pieņemts uzskatìt septiņus gudros, kuru zināšanas aptvēra visdažādākās jomas, viṇu dzīves laiks - 6. gs. p. m. ē, tomēr septinii gudrie ir vairāk mitologíski tēli. No 5 . gs p. m. ē. saglabājušās ziṇas par reāli dzīvojušiem zinātniekiem.

2 Apollonija tekstā grūti izcelt konkrētu terminu definīcijas, teksts ir koncentrēts un informācijas ziṇā loti blīvs, mūsdienu lasītājam grūti uztverams, tāpēc šajā rakstā terminu skaidrojumi doti pārstāsta veidā un pamatojoties uz Liddell E Scott's GreekEnglish Lexicon vārdnīcas paskaidrojumiem par konkrētajām Apollonija teksta vietām.

3 Domājams, ka pašos pirmajos tekstu variantos zīmējumu nebija, tie pievienoti vēlāk.

4 Nav iespējams precīzi noteikt, kad senākajos ǵeometrijas tekstos kā papildu uzskates līdzeklis parādījās zīmējumi, tomēr arheologiskajos izrakumos atrastā keramika apliecina, ka trauku veidotāji jau ap 8. gs. p. m. è. mācēja pareizi uzzīmēt sarežğìtas geometriskas formas.

\section{BIBLIOGRĀFIJA}

Apollonius Pergaeus. Apollonii Pergaei quae graece exstant cum commentariis antiquis. Edidit et latine interpretatus est I. L. Heiberg, Lipsiae, B. G. Tuebneri, 1891.

Apollonius of Perga. Conics (book I-III). Trans. by R. Catesby Taliaferro, diagrams by William H. Donahue, introduction by Harvey Flaumenhaft. Santa Fe, N. M., Green Lion Press, 1998.

Aristotle. Metaphysics. Perseus Digital Library [cited 9 December 2012]. Available: http:// www.perseus.tufts.edu/hopper/text?doc $=$ Perseus $\% 3$ Atext $\% 3$ A1999.01.0052\%3Abook\%3D5\% 3Asection\%3D1016a

Aristotle. On Rhetoric. A theory of civic discourse. Trans. with introduction, notes, and appendices by George A. Kennedy. New York - Oxford : Oxford University Press, 2007.

Liddell, Henry George, Scott, Robert. A Greek-English Lexicon. Perseus Digital Library [cited 9 December 2012]. Available: $h t t p: / / w w w . p e r s e u s . t u f t s . e d u / h o p p e r /$

Saiber, Arielle. Giordano Bruno and the Geometry of Language. England : Ashgate Publishing, Limited, 2005. 
The Institutio oratoria of Quintilian. Trans. by H. E. Butler. Cambridge - Massachusetts : Harvard University Press, 1921.

Webb, Stephen H. Re-Figuring Theology: The Rhetoric of Karl Barth. State University of New York Press, 1991.

\section{Līva Bodniece, University of Latvia, Latvia}

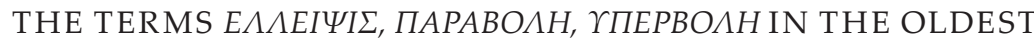 TEXTS OF RHETORIC AND GEOMETRY}

The terms ellipse, parabola and hyperbola/hyperbole almost simultaneously entered both the texts on rhetoric and geometry of the antiquity, and they are also used in the language of modern science and function in the terminology of both the humanities and natural sciences.

Watching and recording of observations were the first steps in the development of scholarly literature. The expression of the oldest scientific texts is of a narrative and descriptive character, even imaginative, from today's point of view. Regardless of the branch of scholarship, facts are illustrated using associative comparisons. When the observed correlations, processes or phenomena are described, they are represented with reference to the processes in nature and everyday life.

Designations for the concepts to see and to know in ancient Greek were formed from the stem of the same verb. One can know what is seen with one's own eyes. In the ancient Greek world perception, the comparisons with what is actually seen make abstract concepts understandable, therefore it is natural that such comparisons are used in the formation of terms. 


\section{ILONA GORNEVA}

Latvijas Universitāte, Latvija

\section{LIETDERĪGĀKAIS RUNAS VEIDS: MENANDRA RĒTORA TRAKTĀTU LIECĪBAS}

\section{İss kopsavilkums}

Vēlīnā daiḷrunas teorija, ko šajā gadījumā pārstāv Menandrs Rētors un viṇa devums rētorikas domas attīstībā, īpaši akcentē epideiktiskās daiḷrunas nozīmi, pievēršot uzmanību tās izpausmes formām, kā arī sistēmas, klasifikācijas kopējam veidolam. Epideiktiskā daiḷ̂runa, kas, pētot Menandra tekstus, atklājas visai raiba un daudzšķautņaina, paver arī improvizācijas iespējas, kas ir viens no lielākajiem izaicinājumiem runas teicējiem. Detalizētajā runu dalījuma shēmā visizteiktāk improvizācijas gaisotne atklājas tieši sarunveida runā $(\lambda \alpha \lambda \iota \alpha ́)$, kuru Menandra Rētora skatījumā pretstatā pārējiem runas veidiem neraksturo noteikts saturiskais un/vai formālais piepildïjums.

Atslēgvārdi: Menandrs Rētors un viṇa traktāti, epideiktiskā daiḷruna, rētorikas klasifikācija, sarunveida runa $(\lambda \alpha \lambda \iota \alpha ́)$.

Rētorikas jautājumi antīkās pasaules laiku griežos allaž ir bijuši uzmanības lokā. Visticamāk, tieši to dzīvot un izdzīvot spēja pilnīgi atšḳirīgās sabiedriski politiskās situācijās noteica visai likumsakarīgu daiḷrunas mācības modeli: pirmkārt, tas nemitīgi ir jāslīpē un jāpilnveido, otrkārt, tam lielākā vai mazākā mērā ir jāmainās vai drīzāk jāspēj pielāgoties attiecīgā laika prasībām, pie tam, kas ir ne mazāk svarīgi, nezaudējot savus kvalitātes rādītājus.

Menandrs no Laodikas, kas plašāk pazīstams kā Menandrs Rētors, mūsu ēras 3. gadu simteņa sofists, daiḷrunas teorētiķis un, sekojot paša tekstos dotajām norādēm, visticamāk, ar̄̄ praktiḳis, divos epideiktiskajai daiḷrunai veltītos traktātos ${ }^{1}$ māca, kā pieklājas runāt visdažādākajās dzīves situācijās, ar kurām likumsakarīgi jāsaskaras ne tikai sabiedriski un politiski aktīvam cilvēkam, bet arī tādam, kas, iespējams, visai rimti vada savu personīgo dz̄ivi. Šajā gadījumā tuvāk skatīts Menandra Rētora

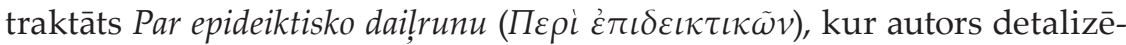
ti, pat skrupulozi pievēršas epideiktisko runu dalījumam un komentāriem par to, kā attiecīgais runas veids būtu sastādāms pareizi. 
Tāpat, kas zīmīgi, analizējot rētorikas dalījuma un klasifikācijas principus, Menandrs raisa savu domu gājumu tieši no epideiktiskās daiḷrunas skatpunkta. Vienīgā vieta Menandra tekstos, kur autors paraugās it kā ārpus epideiktiskās daiḷrunas robežām, ir Genetlijam veltītā traktāta

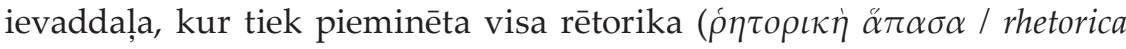
universa $a^{2}$ :

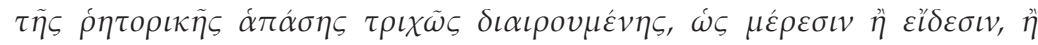

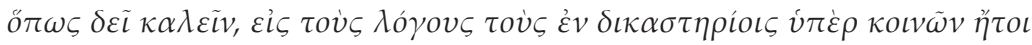

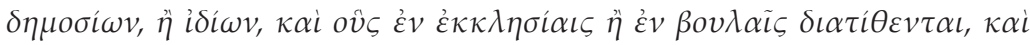

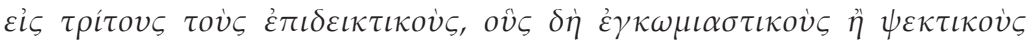
$\kappa \alpha \lambda o \tilde{v} \sigma \iota$.. $(127,1 ; 128,1-5)$

Visa rētorika ir iedalāma trīs daḷās vai veidos, vai, kā [šīs daḷas] pieklājas saukt, tādās runās, kas tiek teiktas tiesvedībā par kopīgām jeb valstiskām lietām vai arī personīgiem jautājumiem, kā arī tādās runās, kuras tiek teiktas tautas sapulcēs vai padomēs, treškārt, epideiktiskās runās, kuras patiesi dēvē par cildinošām vai nopelıšām .. ${ }^{3}$

Šì tekstvieta ir dažādi vērtējama. No vienas puses, tā ir artava jau Aristoteḷa iedibinātajai daiḷrunas dalīšanas shēmai, kas savā vienkāršībā izrādījusies tik ǵeniāla, ka pat neprasa īpašus pierādījumus - dzīvotspēja runā pati par sevi. No otras puses, Menandrs, kas ir pārṇemts ar lietu klasifikāciju, pareizās kombinācijas atrašanu un skaidrošanu rētorikas jomā, pilnībā ignorē divus rētorikas veidus, jēdzieniski visas to funkcijas nododot epideiktiskajam. Jautājums paliek atklāts, par ko īsti tas varētu liecināt. Vai tiešām epideiktiskā daiḷruna pārṇem visas rētorikas funkcijas? Tāpat vai tas varētu būt tik pārsteidzošs pieņēmums laikā, kad tīri funkcionāli politiskā (pilsoniskā?) vai tiesu runa zaudē to esenci, kas bija tik likumsakarīga un vitāli svarīga, piemēram, klasiskā perioda Atēnās? Lai vai kā, Menandra skatījumā epideiktiskā daiḷruna veic savu triumfa gājienu, epideiktiskā daiḷruna ir tā, kas ir jāmāca savam lasītājam, un tieši zem epideiktiskās daiḷrunas pārklāja ir paslēpies tas runas veids, ko teorētiḳis postulē kā vislietderīgāko runas teicējam.

Pavisam Menandra traktātā Par epideiktisko daiļrunu izšk,irti 16 runu veidi $^{4}$, respektīvi, arī traktāta izklāsts, tipoloǵiski vērtējot, ir balstīts uz klasifikāciju. Tiecoties pēc nosacīti ideālās epideiktisko runu dalījuma shēmas, autors ievēro šādu loǵiskās sakarības virkni: pirmkārt, ir skaidri jāidentificē runas sastādīšanas iemesls, proti, notikums, kam par godu attiecīgā runa tiks teikta, otrkārt, runas teicējam ir skaidri 
jāapzinās runas funkcija, tas, ko ar runu vēlas panākt (tātad lielā mērā uz auditoriju vērsts apsvērums), treškārt, balstoties uz diviem iepriekš minētajiem priekšnosacījumiem, var tikt identificēts jau konkrēts runas veids. Šādu shematisku skaidrojumu nevarēs atrast vienviet raksturotu Menandra tekstā, tas tverams kontekstuāli, vērojot to, kā teorētiķis darbojas ar notikumu, noskaṇu, cilvēku, oratora, auditorijas un pašas runas analīzi. Tas noteikti varētu būt tverams kā viens no Menandra metodis-

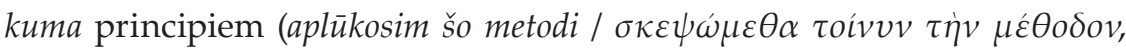
$128,10)$.

Ja palūkojas uz Menandra izšķirtajiem runu veidiem, tos nosacīti var iedalīt trīs daḷās. Pirmā no tām veltīta valstiski svarīgiem jautājumiem. Uz šāda veida runām attiecināma, piemēram, impēriskā runa jeb runa im-

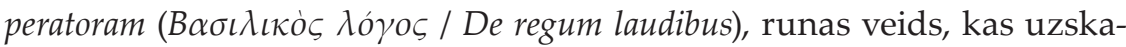
tāms par rafinētu valdnieka/imperatora cildinājumu: lai gan Menandra tekstu korpusā ir grūti analizēt tekstu izkārtojuma secību, tomēr, iespējams, ne bez nozīmes ir atstājams fakts, ka impēriskā runa parasti tomēr tiek uzrādīta kā pirmā nosacìtajā runu uzskaitījumā. Tāpat kronēšanas

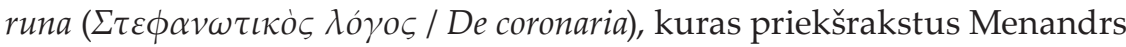

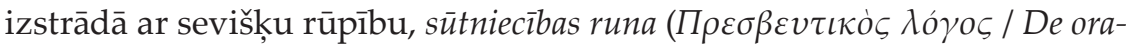

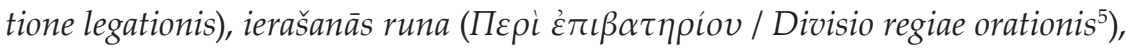
kas pēc būtības saistās ar gubernatoru sagaidīšanu provincē.

Ne mazāk niansēti atklājas tā runu daḷa, kas reprezentē cilvēka personīgās dzìves ritus. Šajā gadījumā ìpaši spilgti novērtējama arī runas funkcija, kas it kā viena notikuma ietvaros tomēr diferencē epideiktiskās runas veidu. Cilvēka dzīves riti aptver laika posmu no dzimšanas līdz pat nāvei, respektīvi, Menandrs izšḳir dzimšanas dienas

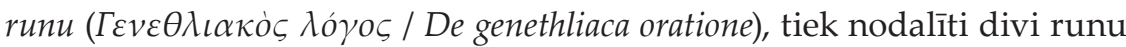

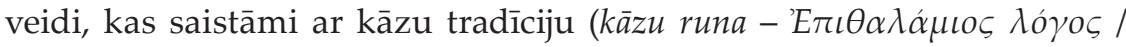

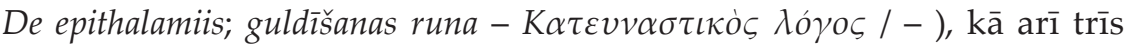
runu veidi, kas saistāmi ar bēru tradīciju, pie tam diahronā izvērtējumā. Divi runu veidi attiecināmi uz cilvēka privāto bērēšanas ceremoniju

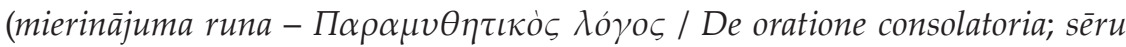

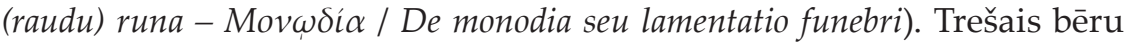

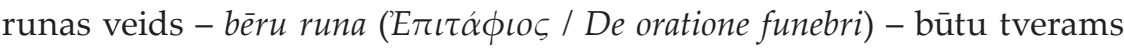
kā izteikta artava tradīcijai, proti, tai bēru runai, kas praktizēta klasiskā perioda Atēnās publiskajā bēru ceremonijā par godu attiecīgajā kaujā kritušajiem cīnītājiem. Zināmā mērā šis runas veids tuvojas valstiski svarīgo runu grupai, bet, protams, domājot par attiecīgo periodizāciju. 
Menandra izvērstajā klasifikācijā ir rodami arī tādi runu veidi, kas nepārprotami nav iekḷaujami nedz privātajā, nedz arī valstiskajā kategorijā, bet tām jebkurā gadījumā, lai gan attiecīgajam notikumam pielāgojama, ir izteikta limitējošā funkcija. Piemēram, iespējams, par tādu varē-

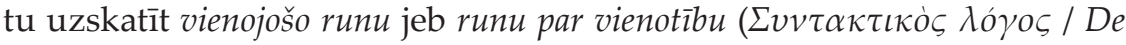
adiungente), kas pēc savas būtības ir atvadīšanās runa. Šim runas veidam Menandrs dod izteikti tēlainu nosaukumu: saites, kas vieno aizceḷojošo ar paliekošajiem, ir tematika, kas aktuāla šāda tipa runas sastādītājam.

Jebkurā gadījumā, lai arì sastopami tēlaināki runu apzīmējumi, runas saturs Menandra uzstādījumā vairumā gadījumu nosakāms jau pēc attiecīgās runas nosaukuma. Ja arī tas nav izdarāms uzreiz pēc nosaukuma, Menandrs ir uzticīgs savai shēmai runu nošķīruma ziņā: ir jābūt skaidram runas teikšanas iemeslam un mērḳim (funkcionālā identifikācija). Tomēr vienā gadījumā Menandrs izteikti atkāpjas no savas principialitātes. Tā ir runa, kurai sofists nespēj pateikt priekšā savam potenciālajam lasītājam jeb māceklim noteiktu runas saturu; tas pēkšṇi kḷūst par ārkārtīgi stiepjamu jēdzienu. Savā ziṇā varētu teikt, ka tas ir gadījums, kad runas priekšplānā izvirzās pats runas teicējs un visas tās izvēles, ko viņš kā runas sastādītājs var veikt, lielā mērā paverot ceḷu improvizācijai

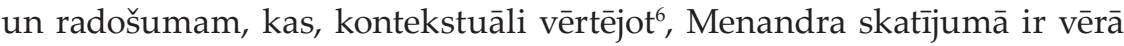
n,emamas kvalitātes. Šis brīvībai imponējošais runas veids Menandra klasifikācijā ir tas, ko teorētiḳis nosauc par sarunveida runu $(\Lambda \alpha \lambda \iota \alpha$ / De lalia). Domājot par leksēmas $\lambda \alpha \lambda \iota \alpha ́$ morfoloǵiju un semantiku, nevar ignorēt arī darbības vārdu $\lambda \alpha \lambda \dot{\varepsilon} \omega$ ar sākotnējo pḹāpāšanas nozīmi, pie tam ne bez onomatopoētisma klātbūtnes.

Tomēr kas Menandra izvērtējumā nosaka sarunveida runas īpatnības, garantējot šo īpašo runas statusu? Vispirms Menandrs piesaka sarunveida runu kā lietderīgāko runas veidu sofistam. Pie tam tādu runas veidu, kas atškirīibā no pārējiem uzskatāmi atbilst diviem rētorikas veidiem, vienlaikus tuvinoties arī politiskajai runai, par ko liecina atbilstošo formētājelementu (pierunāšana un atrunāšana) iesaiste. Tieši sarunveida runas aprakstā vērojams tas, ka Menandrs pavisam skaidri norāda uz faktu, ka vismaz teorētiski viena runa var piederēt pie vairākiem rētorikas veidiem:

Sarunveida runa ir sofistam lietderīgākais [runu] veids, rādās, ka tas attiecināms uz diviem rētorikas veidiem, politisko un epideiktisko; patiesi, ir daudzējāads pielietojums abiem šiem veidiem .. 


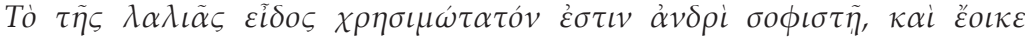

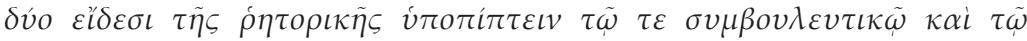

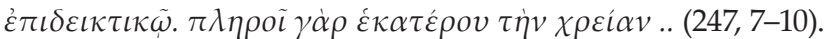

Sarunveida runa pati par sevi ir multifunkcionāla, šajā runas veidā ir

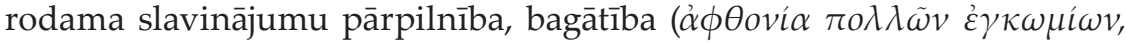
247, 11), jebkura pozitīvā kvalitāte var kalpot par slavinājuma avotu ( $\pi \dot{\alpha} \sigma \eta \varsigma \dot{\alpha} \rho \varepsilon \tau \tilde{\eta} \varsigma \lambda \alpha \mu \beta \dot{\alpha} v \varepsilon \iota v \tau \dot{\alpha} \dot{\varepsilon} \gamma \kappa \omega \dot{\mu} \mu \alpha, 251,8-9)$. Tikpat daudz iespēju paveras arī pretēja rakstura aktivitātēm. Oratoram sarunveida runas ietvaros ir iespēja nopelt kāda dzīvi ( $\psi \dot{c} \gamma \varepsilon \varepsilon \iota v$ ßíov, 247, 20), izsmiet kādu raksturu ( $\kappa \omega \mu \omega \delta \varepsilon \tilde{\imath} v \tilde{\eta} \theta o ́ \varsigma \tau \iota v o \varsigma, 247,19-20)$, kas gan, pēc Menandra

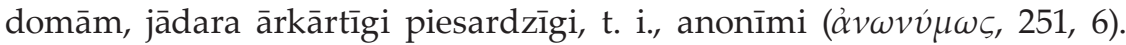
Sarunveida runa paver iespējas iedrošināt, pārliecināt, kā arī atrunāt, tas ir labs veids, kā nepieciešamības gadījumā dot padomu:

.. pie tam caur sarunveida runu dodot padomu gan visai pilsētai, gan ikkatram klausìtājam, ja vien vēlètos, tikpat labi arì tam, kas ir pie varas.

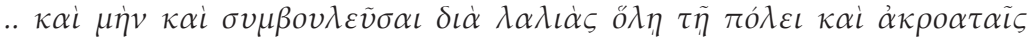

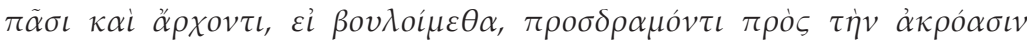
óx́oıv. $(247,13-16)$

Bez tam sarunveida runu kā veiksmīgu vidutāju padoma došanai Menandrs akcentē vairākkārt, iespējams, liekot domāt par sarunveida runu ne tikai kā par vienu no epideiktiskās runas veidiem, bet sarunu kā universālu pārliecināšanas līdzekli vai paṇēmienu:

Caur sarunu vari dot padomu par vienprātību pilsētai, klausìtājiem, draugiem, arī satrauktiem politiskajiem pretiniekiem, vedinot viņus uz savstarpēju saskaņu ..

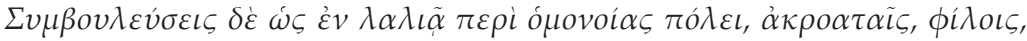

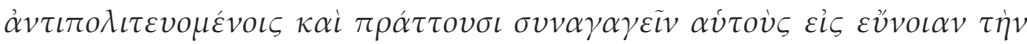
$\pi \rho \dot{s} \varsigma \dot{\alpha} \lambda \lambda \dot{\lambda} \lambda$ ov..$(250,2-5)$

Ne mazāk svarīgs sarunveida runas raksturlielums, ko, visticamāk, pieḷauj plašā saturiskā brīvība, ir oratora iespēja auditorijai pilnībā atklāt savu emocionalitāti jeb, izsakoties Menandra vārdiem, dvēseles stāvokḷus

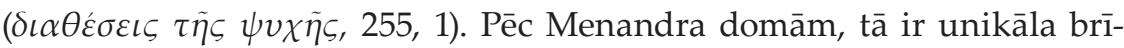
vība, kas nav pieḷaujama nevienā citā runas veidā, kur tas varētu tikt 
uzskatīts, piemēram, par neatbilstību stilam, vispārējai etiķetei - tradīcijas noteiktajam kanonam. Lìdz ar to, ka sarunveida runā vienuviet saplūst tik dažādi, pat pretēji daiḷrunas formētājelementi, runa iegūst īpašu stilistisko nokrāsu. Sarunveida runa neveidosies vienlaidus plūdumā vai plānotā un paredzamā cikliskumā (kā tas varbūt ir sagaidāms citās runās); sarunveida runa pati par sevi paredz pārsteigumu un mainīgumu, ierastās kārtības izjaukšanu:

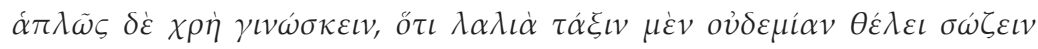

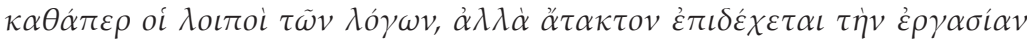

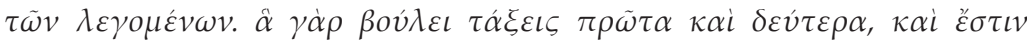
$\dot{\alpha} \rho i \sigma \tau \eta \tau \dot{\alpha} \xi \iota \varsigma \tau \tilde{\eta} \varsigma \lambda \alpha \lambda \iota \tilde{\alpha} \varsigma \tau \dot{o} \mu \dot{\varepsilon} v \kappa \alpha \tau \dot{\alpha} \tau \tilde{\omega} v \alpha \dot{v} \tau \tilde{\omega} v \beta \alpha \delta i \zeta \varepsilon \iota v \sigma v v \varepsilon \chi \tilde{\omega} \varsigma, \alpha \dot{\alpha} \lambda \lambda^{\prime}$

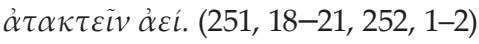

Bet tas arī noteikti ir jān̨em vērā, ka saruna nevēlas ievērot nekādu secību, lìdzīgi kā ir ar pārējāmm runām, bet pieḷauj runājamā neregulāru izklāstu: to, ko vēlies, vari likt secības ziņā vai nu pirmajā, vai otrajā vietā, un labākā sarunveida runas kārtība ir nevis [allaž sekot] vienās un tajās pašās pēdās, bet vienmēr ar neregularitāti.

Šāds mainīgums, izmantojot krasos pretstatu tēlus, ko aț̣auj un nosaka epideiktiskā daiḷruna (slavinājuma un nopēluma valence), kā arī politiskās runas formanti (pierunāšanas un atrunāšanas valence), ḷauj bagātināt tekstu ar rētoriskajām figūrām ( $\sigma \chi \eta \mu \alpha \tau i \zeta \varepsilon \iota v, 247,18-19)$, kas, iespējams, nav tik uzkrītoši panākams runā ar samērotu plūdumu.

Raksturojot sarunu/sarunveida runu, teorētiḳis patiesi atsvabinās no tiem kritērijiem, kurus tik cītīgi ievēro citu epideiktiskās runas veidu izklāstā. Saruna var būt risināta par jebko, sofista izaicinājums šajā gadījumā ir iemācīt savu lasītāju, mācekli, ja tā var izteikties, runāt par visu, un tas ir grūts uzdevums abiem. Nav vienotas sižetiskās līnijas vai struktūras ar stingri sakārtotu tematisko loku, kam runas teicējs varētu sekot. Nav nosaucams kaut kāds noteikts notikums, kam par godu sarunveida runa varētu tikt risināta, tikpat grūti identificējama ir runas funkcija. Tā nav imperatora kronēšanas runa, kur, neraugoties uz visu tās atbildību, ir noteikti priekšraksti, tradīcija, rētoriskās formulas, kas oratoram ir vienkārši jāzina. Sarunveida runa, līdzīgi pēkšṇi dzimušai sarunai, ir kā negaidīta atskārsme, lielā mērā atkarīga no noskaṇas, ko ir jāmāk uzḳert, saturēt un izvērst pašā runas veidošanas procesā.

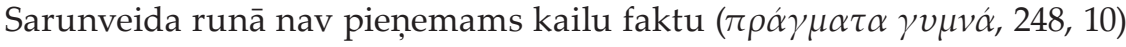
uzskaitījums, stāstījumam jāpiemīt saldmei $(\gamma \lambda v \kappa v ́ \tau \eta \varsigma, 248,13)$, runas 


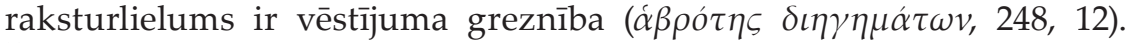

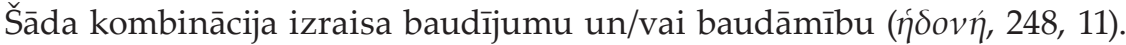

Tādējādi sarunveida runai pēc savas dabas ir jābūt spraigai, dzīvai, saturam izdaiḷotam ar dažādiem stāstiem un pastāstiem. Ja kādai situācijai neatrodas stāsts no pagātnes, ko varētu iesaistīt stāstījuma bagātināšanas nolūkos, orators nedrīkst kautrēties stāstus izdomāt pats. Stāstu izdomāšana nav vienkārša, jo tiem ir jābūt ticamiem, tāpēc der arī sapṇu izgudrošana:

bet vajag arī sapn,us izgudrot un kādas baumas kā kaut ko dzirdētu pasniegt, un vềlèties šìs ziñas pavēstìt klausītājiem ..

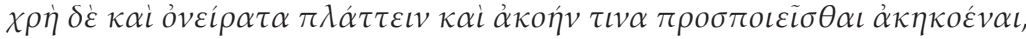

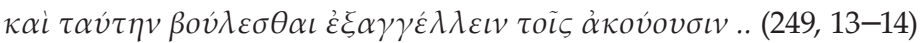

Sarunveida runa ḷauj vaḷu oratora izdomas garam, protams, ievērojot saprātīgā robežas. Varētu teikt, ka tieši šai runas veidā atklājas tas, kādam, pēc Menandra domām, ir jābūt oratoram: neraugoties uz nosacīti lielo brīvību, kas vinam dota, oratoram jābūt samērīgam, apzinoties piel̦aujamā robežas. Oratoram jākḷūst līdzīgam cikādei, mazai radībai, kurai piemīt skaista balss, bet nevis lielam un uzkrītošam, kādi, iespējams, ir daži dziedātājputni:

proti, biežāk samèrīgi izvērtējot, lìdzīgi kā cikāde atdarina dziedātājputnus ..

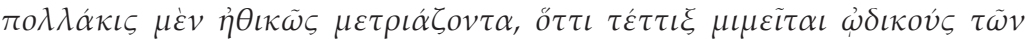
ò $\rho$ i $\theta \omega v$.. $(251,12-14)$

Oratoram ir liels spēks, bet pār to ir jāmāk valdīt. Sarunveida runa, lai arī neprasa nedz stingru kārtìbu, nedz izteiktu sekošanu kanonam, ir lietderīgākā, bet līdz ar to arī viens no lielākajiem izaicinājumiem daiḷrunas apgūšanas jomā.

\section{ATSAUCES}

1 Menandram Rētoram piedēvētie traktāti:

(I) Menandra Rētora epideiktiskās daiḷrunas dalījums Genetlijam (MENANAPOY

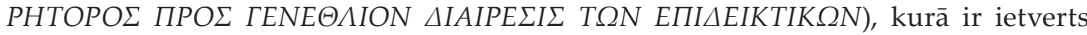
himnu raksturojums, kā arī sniegtas norādes par slavinājuma veidošanu visai plašam tematiskajam lokam, par dalījuma kritēriju šajā gadījumā izvēloties dažādus geogrāfiskos objektus;

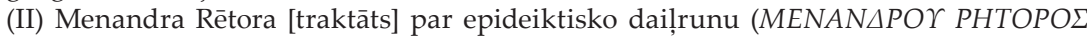
ПЕРI ЕПI $\triangle E I K T I K \Omega N)$, kurā sniegts izvērsts epideiktisko runu dalījums. 
Šo abu traktātu kopums arī saprotams kā Menandra Rētorika (Rhetores Graeci ex Codicibus Florentinis Mediolanensibus Monacensibus Neapolitanis Parisiensibus Romanis Venetis Taurinensibus et Vindobonensibus emendatiores et auctores. Edidit C. Walz. Vol. IX. Londini : Firmin, Didot., 1836; Cf. Rhetores Graeci ex Codicibus Florentinis Mediolanensibus Monacensibus Neapolitanis Parisiensibus Romanis Venetis Taurinensibus et Vindobonensibus emendatiores et auctores. Edidit Spengel Leonardus. 3 vol., Leipzig : Teubner, 1854-1856. Vol. I, pt. 2, reedited by Caspar Hammer. Leipzig: Teubner, 1894).

2 Šeit un turpmāk par citātu avotu origināalvalodā izmantots K. Valca (Christianus Walz) sastādītais izdevums (Rhetores Graeci ex Codicibus Florentinis Mediolanensibus Monacensibus Neapolitanis Parisiensibus Romanis Venetis Taurinensibus et Vindobonensibus emendatiores et auctores. Edidit C. Walz. Vol. IX. Londini : Firmin, Didot., 1836). Tāpat paralēli atsevišķiem atslēgvārdiem vai runu nosaukumiem var tikt uzrādīts Natala Konti (Natale Conti) tulkojums latīnu valodā (Menandri Rhetoris de genere demonstrativo libri duo a Natale de Comitibus translati. Venetiis apud Petrum Bosellum, 1558). Teksta latīniskā versija netiek uzrādīta plašāku citātu iesaistes gadījumā vai arī situācijās, kad attiecīgais runas nosaukums/runas veids nav sastopams latīṇu tulkojumā, pēdējā gadījumā trūkstošā teksta vietā norādīta domuzīme $\left({ }_{(,-}-{ }^{\prime \prime}\right)$.

3 Šeit un turpmāk iesaistītajiem citātiem oriǵinālvalodā uzrādīts autores latviskojums.

4 Menandra Rētorikā stabili izšḳirami ir 16 runu veidi. Atkarībā no teksta organizācijas var parādīties 17. runas veids, kas var tikt interpretēts kā viens no topiem impēriskās runas ietvaros (Russel, Wilson 1981, 78-95).

5 Burt. tulk. no latīnu val. valstiskās/impēriskās runas dalījums.

6 Izdomātspēja, sacerētspēja Menandra skatījumā ir augstu vērtējama teksta radītāja īpašība, tas, piemēram, tiek akcentēts fiktīvo himnu kontekstā.

\section{BIBLIOGR ĀFIJA}

Menander Rhetor. Trans. and commentary by D. A. Russel and N. G. Wilson. Oxford : OUP, 1981.

Menandri Rhetoris de genere demonstrativo libri duo a Natale de Comitibus translati. Venetiis apud Petrum Bosellum, 1558.

Rhetores Graeci ex Codicibus Florentinis Mediolanensibus Monacensibus Neapolitanis Parisiensibus Romanis Venetis Taurinensibus et Vindobonensibus emendatiores et auctores. Edidit C. Walz. Vol. IX. Londini : Firmin, Didot, 1836.

Rhetores Graeci ex Codicibus Florentinis Mediolanensibus Monacensibus Neapolitanis Parisiensibus Romanis Venetis Taurinensibus et Vindobonensibus emendatiores et auctores. Edidit L. Spengel 3 vol., Leipzig : Teubner, 1854-1856. Vol. I, pt. 2, reedited by Caspar Hammer. Leipzig : Teubner, 1894.

Ilona Gorņeva, University of Latvia, Latvia

\section{THE MOST APPLICABLE KIND OF SPEECH: TESTIMONIA OF TREATISES BY MENANDER RHETOR}

Menander of Laodicea, best known as Menander Rhetor, $3^{\text {rd }}$ cent. AD sophist, theoretician of elocution and, according to indications in his own texts, possibly a practitioner, in his two treatises on epideictic elocution teaches how to speak out appropriately in various life situations. 
Menander views the whole system of rhetoric through the prism of epideictic elocution, also offering a detailed scheme of classification which the theoretician himself develops and substantiates. Within this classification there is only one type of epideictic branch of speeches that, according to the author, offers the richest potential for the orator. This potential comprises the features that determine the freedom of content, freedom from formal conventions, although giving every possibility to involve rhetorical figures, thus defining the special status of a conversational speech in Menander Rhetor's classification.

Conversational speech is open to the orator's imaginative spirit. It may be that this type of speech reveals Menander's idea of an orator: notwithstanding the relative freedom that is given to the orator, he has to possess a good sense of measure and respect the limits of what is admissible.

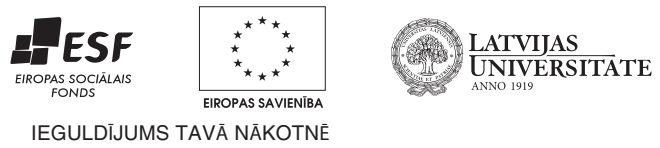

Šis darbs izstrādāts ar Eiropas Sociālā fonda atbalstu projektā „Atbalsts doktora studijām Latvijas Universitātē". 


\section{IGORS KONINS}

Rīga, Latvija

\section{TĒLA VEIDOŠANA ANTĪKAJĀ RĒTORIKĀ UN PSEIDOVĒSTURISKĀS VĒSTULES}

\section{İss kopsavilkums}

Rakstā pētīta galvenā varoṇa tēla veidošana ${ }^{1}$ Temistokla vārdā nosauktajās pseidovēsturiskajās vēstulēs, kuras tiek pieskaitītas pie rētorisko skolu vingrinājumu paraugiem. Tas darīts, salīdzinot zināmās iez̄̄mes vēsturiskajā Temistokla valodā un vēstulēs. Šìs iezīmes tika pamatā aizgūtas no zinātniskās literatūras. Darba rezultātā secināts, ka vēstules iedalāmas divās daḷās atbilstoši dažādiem autora mērķiem. Vēstuḷkopas pirmajā daḷā rādīts lepnuma pilns tēls, kurš ir satraukts par savu stāvokli. Par satraukumu liecina hiperbata figūras, par varoṇa ciešanām - leksika ar emocionāli sakāpinātu nokrāsu. Šajā daḷā visplašāk parādās vēsturiskajam Temistoklam piemītošās lepnā cilvēka valodas ìpatnības. Otrajā vēstuḷkopā iezīmes, kas norāda uz satraukumu un lepnumu valodā, tikpat kā izzūd. To izskaidro autora mērḳis: parādīt cilvēku, kas spēj mierīgi spriest par lietām un ir gatavs darīt visu dzimtenes labā.

Atslēgvārdi: pseidovēsturiskās vēstules, Temistokla tēls, raksturojums, valodas ìpatnības, lepnums, satraukums.

Antīkā pasaule ir īpaši slavena ar savu izstrādāto rētorikas teoriju.

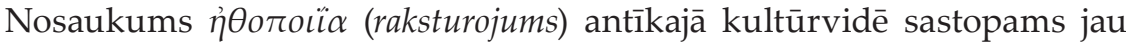
1. gs. p. m. è. Vēlīnajā antikvitātē ar to parasti saprata vienu no vairākām rētoriskajām figūrām, kuras bija saistītas ar literārā darba varoṇa jeb alter ego rakstura izstrādi. Marks Fabijs Kvintiliāns (Marcus Fabius

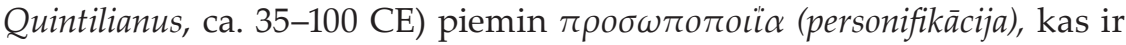

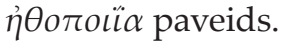

29. (..) Illa adhuc audaciora et maiorum, ut Cicero existimat, laterum, fictiones personarum, quae prosopopoiiae dicuntur: mire namque cum variant orationem tum excitant. 30. His et adversariorum cogitationes velut secum loquentium protrahimus (qui tamen ita demum a fide non abhorrent si ea locutos finxerimus quae cogitasse eos non sit absurdum), et nostros cum aliis sermones et aliorum inter se credibiliter introducimus, et suadendo, obiurgando, querendo, laudando, miserando personas idoneas damus. 
29. (..) Š̀ [figūura] ir vēl drosmīgāka un, pēc Cicerona domām, tai vajadzīgs

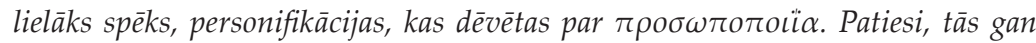
brīnumaini dažādo runu, gan piešķir tai spēku. 30. Ar to palīdzību mēs atklājam pretinieku domas, itin kā viñi tās paustu, runādami ar sevi (kuras tomēer ir ticamas tikai tad, ja pasniedzam tās tādas, kādas viņi būtu varējuši iedomāties), un ticami ievadām gan mūsu sarunas ar citiem, gan citu sarunas savā starpā, un ar pārliecināšanu, atrunāšanu, sūdzībām, slavināšanu, līdzi jušanu veidojam piemērotas personas. ${ }^{2}$

Vēlāk šis nosaukums sastopams rētorikas skolu vingrinājumos jeb $\pi \rho o \gamma v \mu v \alpha ́ \sigma \sigma \alpha \tau \alpha$. Tie bija domāti tam, lai sākotnējā līmenī iepazīstinātu skolniekus ar rētorikas zinātni un sagatavotu viņus deklamācijām par politiskām tēmām. Līdz mūsdienām saglabājušās šo vingrinājumu mācību grāmatas, vecākās no m. è. 1. gadsimta.

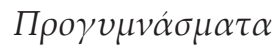

- Mācību grāmatas, kurās sīki bija aprakstīta prozas sacerēšanas un elementārās rētorikas mācību sistēma, kas tika praktizēta Eiropas skolās no hellēnisma perioda līdz agrīnajiem jaunajiem laikiem (Kennedy 2003, ix).

- Virkne noteiktu pieaugošas sarežǵītības vingrinājumu, kas daudziem kalpoja par mutvārdu un rakstveida izteiksmes avotu un palīdzēja trenēties publiskajā runā (Kennedy 2003, ix).

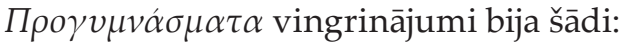

- $\mu \tilde{v} \theta o \varsigma$ (fabula, sižets),

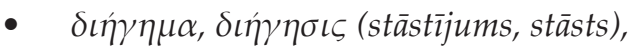

- $\quad$ х $\rho \varepsilon i \alpha$ (anekdote, hreija),

- $\gamma v \omega ́ \mu \eta$ (gnoma, sentence),

- $\quad \dot{\alpha} v \alpha \sigma \kappa \varepsilon v \eta ́$ (atspēkojums),

- $\kappa \alpha \tau \alpha \sigma \kappa \varepsilon v \dot{~(a p s t i p r i n a ̄ j u m s), ~}$

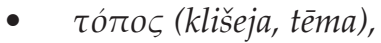

- $\quad \dot{\varepsilon} \gamma \kappa \omega ́ \mu \nu o v$ (slavinājums),

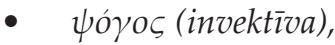

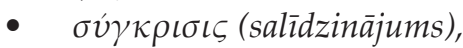

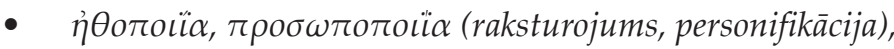

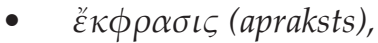

- $\theta \dot{\varepsilon} \sigma \iota \varsigma$ (tēze, propozīijija),

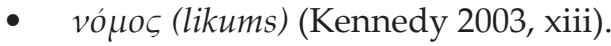

Minētajiem vingrinājumiem bija sava vieta antīkajā izglīìibas sistēmā: vispirms bija jāapgūst t. s. $\dot{\varepsilon} \gamma \kappa \hat{v} \kappa \lambda \iota \alpha \mu \alpha \theta \eta \mu \alpha \tau \alpha$ lasišsana, 
rakstīšana u. c., tad $\pi \rho o \gamma v \mu v \alpha ́ \sigma \mu \alpha \tau \alpha$, kam sekoja uzstāšanās ar deklamācijām. Taču arī tad $\pi \rho o \gamma v \mu v \alpha ́ \sigma \mu \alpha \tau \alpha$ vingrinājumiem bija sava vieta rakstveida formā (Kennedy 2003, x).

Про $v \mu \nu \alpha \dot{\alpha} \sigma \mu \alpha \tau \alpha$ mācību grāmatu autori:

- Aēlijs Teons, m. è. 1. gs.,

- Hermogens no Tarsas, m. è. 2. gs.,

- Aftonijs Sofists, m. è. 4. gs. otrā puse,

- $\quad$ Nikolajs Sofists, m. è. 5. gs. otrā puse (Kennedy 2003, ix).

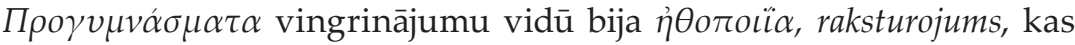
nozīmēja ieteikumus, ar kuriem tika atdarināts kāds tēls.

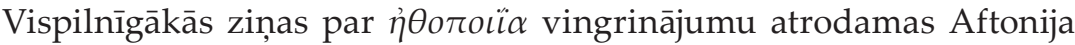
pamācībā:

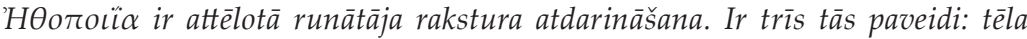

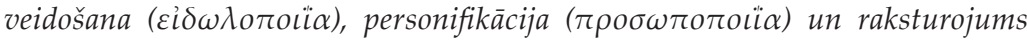

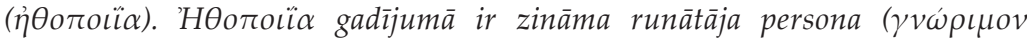
$\pi \rho o ́ \sigma \omega \pi \mathrm{\sigma})$, tiek izdomāts tikai raksturojums, tāpēc [tāda atdarināšana] tiek dèvēta par raksturojumu; piemèram, kādus vārdus teiktu Hērakls, kad Euristejs dotu pavēli. Šajā gadījumā Hērakls ir zināms, mēs izdomājam tikai raksturu,

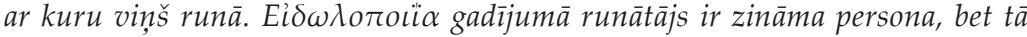
ir mirusi un pārstājusi runāt, kā Eupolida raksturs, kas izdomāts vina ${ }^{3}$ darbā "Demoi" un Aristīda runā "Četru aizstāvībä"; ; [45] tāpēc tā dēvēta par tēla

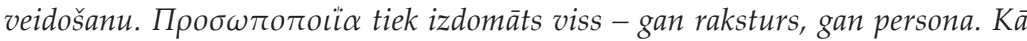
Menandrs izdomāja Elenchos (Atspēkojumu), jo elenchos ir lieta, nepavisam ne

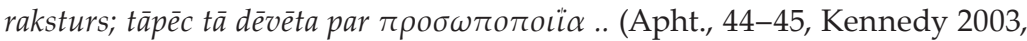
$115-116)^{5}$

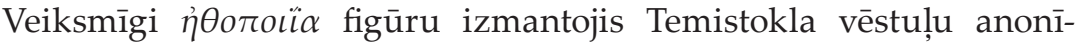
mais autors. Šì vēstuḷkopa pieder t. s. pseidovēsturiskajām vēstulēm. Pseidovēsturiskās vēstules, kas tiek dēvētas arī par pseidonīmiskajām vai pseidoepigrāfiskajām, ir vēstules, ko uzrakstījis anonīms autors pazīstamas personības, dažreiz mītiskas, dažreiz vēsturiskas, vārdā (Rosenmeyer 2006, 97). Šì žanra literāro darbu saistība ar rētoriku ir l,oti cieša, un tie bieži tiek uzskatīti par rētorikas skolu audzēkṇu vingrinājumu paraugiem. ${ }^{6}$

Vēstuḷu ciklu veido 21 vēstule, rakstītas sengrieķu valodā aptuveni m. è. 1. gadsimtā. Sižetiski tās saistītas ar Atēnu valstsvīra Temistokla $(\Theta \varepsilon \mu \iota \sigma \tau \sigma \kappa \lambda \tilde{\eta} \varsigma \text {, ca. 524-459 BC })^{7}$ figūru, kura galvenais nopelns ir uzvara Salamīnas kaujā 480. g. p. m. è., un ar viņa klejojumiem pēc izraidīšanas no Atēnām. 
Vēstuḷkopas autors jeb pseidoepistologrāfs ${ }^{8}$ bija pētījis Temistokla valodu viņam pieejamos vēsturiskajos avotos. Mūsdienās ir konstatēta Tūkidīda un Hērodota vēsturisko darbu izmantošana. Kā tiek uzskatīts, Temistoklam raksturīgās valodas iezīmes ir šādas:

- l̦oti bieža (aptuveni pēc katrām trijām - četrām frāzēm) غ̇ $\gamma \omega \dot{\omega}$ personu vietniekvārda izmantošana dažādās formās, bet visvairāk 1. p. vsk.; (..) turklāt ar vietniekvārdu 1. personā bieži tiek sākta fräze;

- sava "es" pretstatī̌sana citai personai;

- vēršoties pie sava idejiskā pretinieka, kura viedokli Temistoklam nepieciešams atspēkot, cenšoties padarìt vinu par savu piekritēju, bieži lietota sintaktiska konstrukcija: ja tu izdarīsi to un to... (parasti kā slikta veidā), tad sekos tas un tas... [Hellada ies bojā] (Hdt., VIII, 60);

- sintaktiskā konstrukcija ar noliegumu "ne" (ov̉k) fräzes sākumā, kas saskaņojas pretēji loǵikai ne ar to vārdu, ar kuru tai būtu jāsaskaņojas. Piemēram, nevis nepametīsi tu mūs, bet gan ne tu mūs pametīsi; ${ }^{9}$

- izmantota antitēze kā aktīos pārliecināšanas līdzeklis savas un citu gribas pretnostatī̌nanai (leksiskā realizācija - saiklis à $\lambda \lambda \alpha ́$ (bet));

- prasību paklausît atspoguḷo loti daudz darbības vārdu pavēles izteiksmē;

- garu un loti ìsu frāžu mija (īsās - no 3-5 vārdiem) (Попова 1991, 189-190).

Vēstuḷu cikla pirmajā dạ̣ā atspoguḷoti Temistokla iekšējie pārdzīvojumi par dzīvi tālumā no dzimtenes, tie iespaido viņa domu gaitu un valodu.

Viena no spilgtākajām vēstulēm šìs domas ilustrēšanai ir ceturtā, adresēta kādam Habroniham.

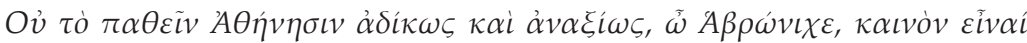

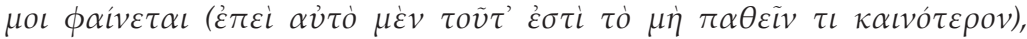

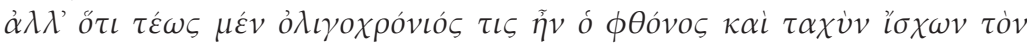

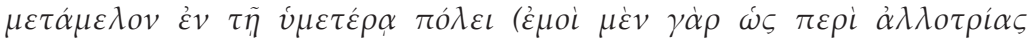

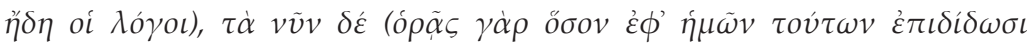

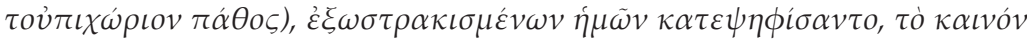

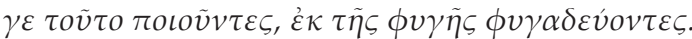

Nevis paciest netaisnīgi un nepelnīti Atēnās, Habronih, man liekas savādi (jo patiesi neciest kaut ko ir savāāāk), bet ka iepriekš skaudība patiesi bijusi ìslaicīga un paturēja ātru nožēlu mūsu pilsētā, drīzāk jūsu pilsêttā (man jau vārdi kā par svešzemi), bet tagad vin̨i (redzi taču, cik l̦oti mums pieaug satraukums par lìdzpilsoņiem), kad mès tikām pakḷauti ostrakismam, atzina mūs par vainīgiem, un, veicot ko savādu, izraida no trimdas (IV, 1,743$)^{10}$. 
Viss citētais teikums ir hiperbata piemērs: ierasta vārdu kārtība būtu: O, Habronih, man liekas savādi nevis paciest Atēnās netaisnīgi un nepelnìti... (Попова 1991, 142). Par to liecina arī trīs parentēzes jeb iestarpinājumi teikumā. Jau pirmie vārdi paciest netaisnīgi un nepelnīti signalizē par ciešanām (leksikas līmenis), pie šādām leksēmām pieskaitāmas arī neciest, satraukums, tikām pakḷauti, atzina par vainīgiem. Teikums būvēts pēc antitēzes principa: man liekas savādi nevis... (jo savādāk ir...), bet gan ka..., bet tagad..., ...un ... Temistokls izsaka paradoksālās domas - man liekas savādi nevis paciest, ... jo savādāk ir neciest..., bet ka skaudība... bijusi... ìslaicīga; izraida no trimdas. Runājot par skaudības klātbūtni, viņš sev labvēlīgo apstākli (to, ka tā bija īslaicīga) konkrētajos apstākḷos ironiski vērtē kā savādu (t. i., neierastu). Varoṇa vārdos ironija jūtama, arī runājot par savu satraukumu. Teikumu noslēdz paradoksālā doma par izraidīšanu no trimdas. Augstprātību apliecinošais vietniekvārds 1. p. vsk. lietots kopā ar 1. p. dsk. formu ${ }^{11}$.

8. vēstulē, cik noprotams ${ }^{12}$, tiek runāts par četrām amatpersonām, kurām bija jāzvēr, ka tās nav iejauktas Temistokla darbībās, kas saistītas ar valsts nodevību. Cilvēki Atēnās acīmredzot tām noticēja.

Sniedzis minēto personu darbību īso novērtējumu, alter ego vēršas pie sava drauga Leagra, kuram adresēta vēstule:

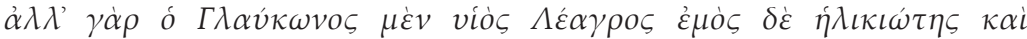
$\sigma v v \varepsilon ́ \phi \eta \beta ం \varsigma .$.

Bet Leagrs, Glaukona dēls, mans vienaudzis un jaunības biedrs .. (VIII, 747)

Teikumā Temistokls dod rīkojumu, kā, pretēji atēniešu viedoklim (antitēze), draugam jāvērtē šie cilvēki.

Nākamajā teikumā Temistokls turpina sakāpināti pretstatīt savu un atēniešu stāvokli:

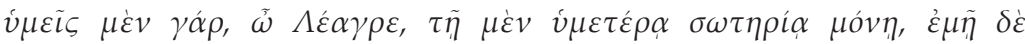

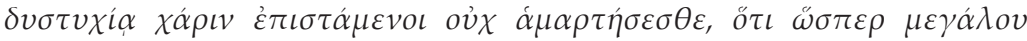

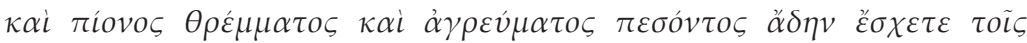

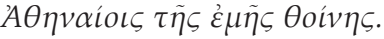

Jūs gan, ak, Leagr, tikai jūsu glābšanai, bet manai nelaimei pateicību izrādot, nekḷūdīsieties, jo pietiekami baudījāt ar atēniešiem manas dzīres, kad kritis liels un trekns dzīonieks un medījums. (VIII, 747)

Par satraukumu liecina leksēmas nelaimei, baudījāt ...manas dzīres (pārnestā nozīmē). Teikumā lietots personu vietniekvārds 1. p. vsk., kā arī 
antitēzes sava un pretinieku stāvokḷa novērtējumā: izglābšanās - nelaime, dzìres - medīiums; izteiktā doma ironijas pilna: adresāts un viņa biedri gan nekḷūdīsies, jo jau iepriekš rīkojušies līdzīgi. Te acīmredzot adresāts jau tiek apsūdzēts par to, ka iedzīvojies uz varoṇa nelaimes rēḳina. ${ }^{13}$ Apvainojumu noslēdz spilgta metafora.

No pirmās vēstuḷu cikla daḷas teksta secināms, ka tekstā iekḷautas alter ego lepnā rakstura valodas iezīmes: vietniekvārds $\dot{\varepsilon} \gamma \omega \dot{\omega}$ vsk. formās, antitēzes lietojums savas un citu nostājas pretstatīšanai, pēc pakḷaušanās prasošie darbības vārdi pavēles formā. ${ }^{14}$ Alter ego pārdzīvojumus pamatā atspoguḷo uz ciešanām norādošā leksika, domas pārtraukumi (hiperbati), paradoksālā veidā izteiktie vērtējumi. Minētais liecina par epistologrāfa emocionālo stāvokli, uztraukumu, rūgtumu (Penwill 1978, 87), atsvešināšanos (Rosenmeyer 2006, 49), tiek runāts pat par naidu (Penwill 1978, 101, 102), paranoju (Rosenmeyer 2006, 49). Traucēta spēja kritiski vērtēt apkārtējo un savu rīcību, notikumus.

\section{Vēstuḷu cikla otro daḷu veido 9 (13-21) vēstules.}

Tajās kopumā novērtējami savas situācijas pārdomāšanas aizsākumi.

Šai sakarā zīmīga 18. vēstule Aristīdam, kurā Temistokls pārdomā vinna labo rīcību sevis labā, kad tika balsots par viṇa notiesāšanu uz nāvi:

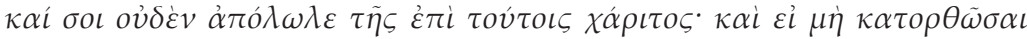

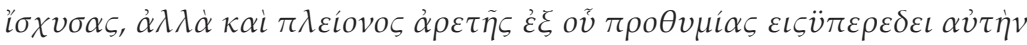

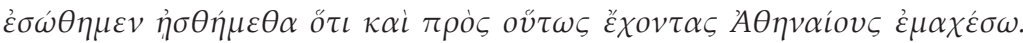

Un tev nekāda pateicība par to nepazuda; pat ja nebiji spèjīgs novest lìdz galam, bet arī lielāku labumu no [tavas] gatavības nepaklauties esam sajutuši, kad bijām izgläbti, jo cīnījies pret šādi noskaņotiem atēniešiem. (XVIII, 757)

Epistologrāfa valodai raksturīgā antitēze lietota citam mērķim, kas ir atškirīgs no pirmajā daḷā nospraustā: kopējā negatīvajā beigu rezultātā tiek novērtēts pozitīvais politiķa devums, kas tobrīd bija iespējams un kas kontrastē ar cikla pirmajā daḷa 4., 9., 12. vēstulē sniegto politiķa Aristīda darbības izteikti negatīvo novērtējumu ${ }^{15}$.

19. vēstulē galvenais varonis raksta Antagoram, cik saprotams, savam agrākajam draugam:

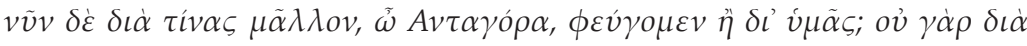

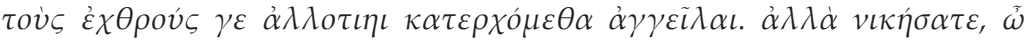




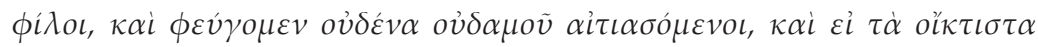
$\pi \varepsilon \iota \sigma o ́ \mu \varepsilon \theta \alpha$.

Bet tagad, ak, Antagor, kādēl drīzāk mès bēgam, ja ne jūsu dēḷ? Jo patiesi ne ienaidnieki vēstī, kad mums reiz jāatgriežas no trimdas. Bet jūs uzvarējāt, ak, draugi, un mès bēgam, nekad nevienu neapsūdzot, pat ja briesmīgi cietīsim. (XIX, 758)

Arī šajā teikumā varoṇa valodai raksturīgās antitēze un nosacījuma palīgteikums lietoti sava stāvokḷa novērtēšanai. Lepnuma mazināšanos apliecina arī pavēḷu trūkums un tas, ka par sevi tiek runāts dsk. 1. personā. Kādreizējais draugs ir kḷuvis par nodevēju, tomēr galvenais varonis neḷauj brīvu vaḷu emocijām. Netiek izteikti nekādi aizvainojumi. Vārdos jūtama vien viegla ironija. Pretinieki tiek saukti par draugiem, Temistokls atzīst, ka nevienu nevaino.

Pēc daudziem piedzīvojumiem, lielā mērā pateicoties paša atjautībai, 20. vēstulē Temistokls veiksmīgi nonāk persiešu valdnieka galmā. Tur viņš uzzina, ka persieši gatavo jaunu gājienu uz Helladu. Temistokls pārdomā savu iespējamo dalību šajā karagājienā.

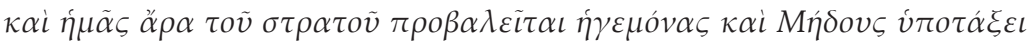

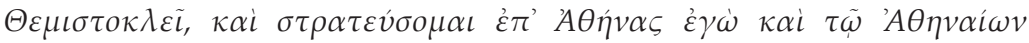

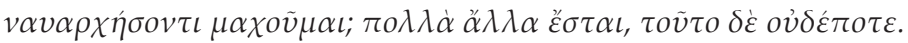

Un mūs iecels par karspēka virspavēlnieku un persiešus pakḷaus Temistoklam, un es vedī̌̌u karaspēku pret Atēnām un cīnīšs pret atēniešu flotes vadoni? Būs daudz kas cits, bet tas nekad. (XX, 762)

Te jāatzīmē doma - Temistokls nekad nebūs dzimtenes nodevējs. Teikumā personu vietniekvārdu 1. p. dsk. atkal nomaina vietniekvārds 1. p. vsk., kas liecina par runātāja lepnuma pieaugumu. No valodas īpatnībām labi novērtējama vien īso un garo frāžu mija - pirmā teikuma daḷa sastāv no 21 vārda, otrā un trešā - no trijiem.

Otrajā vēstuḷu daḷā tātad atklājas „otrā es" spēja apdomāt savu stāvokli un nevienam neizteikt nekādus apvainojumus. No lepnumu apliecinošām valodas iezīmēm šim „Temistoklam” konstatējami vien antitēze un nosacijjuma teikumi, tie lietoti nevis citu, bet gan paša darbību novērtēšanai. Pavēles netiek izteiktas, runājot par sevi, lietota 1. p. dsk. Politikas jomā Temistokls domā par dzimtenes labklājību un 
nekad nedarīs neko tādu, kas varētu tai kaitēt. Par satraukumu liecinošu pazīmju šajā cikla daḷā nav.

Pēc veiktās vēstulu teksta analīzes var secināt, ka anonīmais rētorikas skolas audzēknis, izmantojot savā pseidovēsturiskās epistologrāfijas

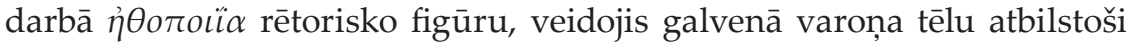
izvirzìtajam mērķim, atklājot viṇa raksturu viṇa paša izteikto apkārtējo notikumu un cilvēku novērtējumā. Atbilstoši dažādiem mērḳiem vēstuḷu cikls veidots diptiha formā. Nospraužot mērḳi pirmajā daḷā attēlot epistolgrāfa satraukumu, rūgtumu, apmātības pilnās domas par dzìvi prom no dzimtenes, kas adresētas vēstuḷu saṇēmējiem, pseidoepistologrāfs to sasniedz ar dažādiem valodas līdzekḷiem. Ciešanas izteiktas ar īpaši piemeklētu leksiku, uztraukums - ar hiberbata figūru, vēršanās pret adresātiem - leksiski, ar spilgtām metaforām, apvainojumu pilniem paradoksāliem spriedumiem. Varonim vēsturiski raksturīgo lepnumu valodā atklāj savas pozīcijas uzsvēršana (leksiskā realizācija - personu vietniekvārda vsk. formā $\dot{\varepsilon} \gamma \omega \dot{~ l i e t o j u m s), ~ s a v a ~ u n ~ c i t u ~ s t a ̄ v o k l ̣ a ~ p r e t n o-~}$ statīšana (antitēzes princips), familiāri izteiktas pavēles, izmantojot darbības vārdus pavēles formā. Otrās vēstuḷu cikla daḷas uzdevums ir pretējs - attēlot alter ego spēju adekvāti vērtēt situāciju un cilvēkus. Epistologrāfs šajā daḷā attēlots kā dzimtenes patriots, kas racionāli un adekvāti vērtē apstākḷus.

Vēstulēs, pamatā pirmajā daḷā, pseidoepistologrāfs atdarina no vēstures avotiem zināmo galvenā varoṇa lepnajam raksturam atbilstošo valodu. To raksturo sava viedokḷa pretstatišana pretinieku viedoklim ar nosacījuma palīgteikumu palīdzību, kas būvēti uz antitēzes principa un bieži ietver sevī darbības vārdus pavēles formā, kā arī dominējošs personu vietniekvārda $\dot{\varepsilon} \gamma \omega$ lietojums. Vēstul,u otrajā daḷā šīs iezīmes gandrīz nav novērojamas.

Jāatzīmē têla veidošanas vieta antīkajā izglītībā: šis vingrinājums bija viens no rētorikas skolu vingrinājumiem ${ }^{16}$, kuri tika kombinēti dažādos veidos, lai rādītu episkā, dramatiskā, vēsturiskā un liriskā žanra darbus $^{17}$. Tā bija iespēja rētorikas skolas audzēknim izmēǵināt sevi, izvēloties kādu tēlu un atspogul,ojot to savā darbā pēc saviem ieskatiem. Neapgūstot šo vingrinājumu, nevarētu rakstīt politiskās runas (kas arī bija galvenā prasība rētorikas skolu beidzējiem), jo galvenais tajās, kā zināms, bija tieši cilvēka darbību un viņa rakstura apraksts vēlamā veidā ${ }^{17}$. Var teikt, ka šādi minēto skolu audzēkṇi vingrināja savu tēlaino domāšanu un mācījās sacerēt literāros darbus. Piel̦auju domu, ka arī 
mūsdienās būtu vērts sagatavot un piedāvāt līdzīgus vingrinājumus studentiem kā iespēju praktizēties literārā darba sacerēšanā.

Auglīga būtu tālākā $\pi \rho o \gamma v \mu v \alpha ́ \sigma \mu \alpha \tau \alpha$ vingrinājumu pētīšana gan no žanru attīstības (anekdotes, invektīva, slavinājums, ar likumdošanu saistītie žanri), gan no prozas literārā darba galveno veidojošo paṇēmienu viedokḷa (fabula, stāstījums, tēmas izvēle, rakstā minētā raksturu izstrāde, retoriskās deklamācijas kāda argumenta atspēkošanai vai apstiprināšanai).

\section{ATSAUCES}

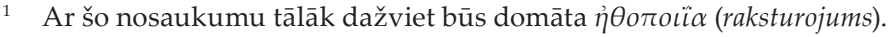

2 Quint. Inst., IX, 2.29-30, autora tulkojums no latīṇu val.

3 T. i., Eupolida.

4 Dž. Kenedijs, komentējot Hermogena piemēru, gan norāda uz Sopatra uzskatu, ka tā

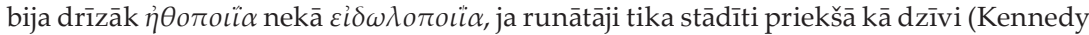
2003, 85). Viss atkarīgs no iedomātā runātāja statusa - ja Hērakls, sakot runu, ir dzīvs, tā

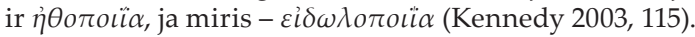

5 Fragmentu no Dž. Kenedija darba tulkojis autors.

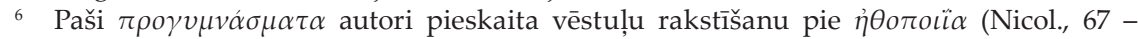

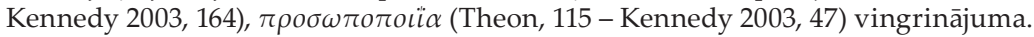

7 Dzīves dati precīzi nav nosakāmi (Lenardon 1978, 24, etc.; Munro 1892, 333; Попова 1991, 187; С Аоварь античности).

8 Tālāk rakstā vēstuḷu anonīmais autors tiek dēvēts par pseidoepistologrāfu, Temistokls par epistologrāfu.

9 Sal. pirmajā citātā - ov̉ $\tau \dot{o} \pi \alpha \theta \varepsilon \tilde{\imath}$. Zinātniskajā literatūrā apspriests jautājums par vēstuḷu neveiklo valodu kopumā.

10 Norāde uz lappuses numuru vēstuḷu izdevumā Epistolographi Graeci. Šajā izdevumā vēstuḷu iekšējais iedalījums (uz to norāda otrais cipars) netiek konsekventi atspoguḷots. Autora tulkojums no oriğinālvalodas (no šì izdevuma).

11 Pēc T. Popovas domām, tas liecina par Temistokla lepnuma mazināšanos (Попова 1991, 142).

12 Jo spriest par tajā minēto var tikai no paša vēstules teksta.

13 Alter ego cilvēka novērtējums tātad var antitētiski mainīties arī vienā vēstulē.

14 Apskatot lielāko teksta fragmentu, novērtējama arī garo un īso frāžu mija.

15 Vēsturiski viňš bija Temistokla pretinieks.

16 Kopā ar fabulu, stāstījumu, hreiju, ekfrāzi, salīdzinājumu u. c.

17 Kennnedy, ix.

18 Piem., Aristoteḷa uzsvērtais runātāja rakstura atklāšanas runā vēlamā veidā nozīmīgums (Arist. Rhet., II, 1).

\section{BIBLIOGRĀFIJA}

\section{Antīkie teksti}

Epistolographi Graeci. R. Hercher (Ed.). Parisiis : Firmin Didot, MDCCCLXXIII, 741-762 (vēstules).

Spengel, Leonardus (Ed.). Rhetores Graeci. 3 vol., Leipzig: Teubner, 1854-56. Vol. I, pt. 2, reedited by Caspar Hammer. Leipzig : Teubner, 1894 (progymnasmata). 
M. Fabi Quintiliani Institutio oratoria. Available:

http://www.thelatinlibrary.com/quintilian/quintilian.institutio9.shtml

\section{Tulkojumi}

Costa, C. D. N. (Ed.). Greek Fictional Letters: a Selection with Introduction, Translation and Commentary. Oxford : Oxford University Press, 2001.

Doenges, N. A. The Letters of Themistocles. N. Y. : Arno Press, 1981. (repr. Princeton, 1953), $130-228$.

Lenardon, R. The Saga of Themistocles. London : Thames and Hudson, 1978, 157-193.

Rosenmeyer, P. A. Ancient Greek literary letters: Selections in translation. L., N.Y. : Routledge, 2006, 56-82.

Trapp, M. Greek and Latin Letters: an Anthology with Translation. Cambridge : Cambridge University Press, 2003.

\section{Zinātniskā literatūra}

\section{Grāmatas (monogrāfijas)}

Doenges, N. A. The Letters of Themistocles. N. Y. : Arno Press, 1981. (repr. Princeton, 1953).

Lausberg, H. Handbook of Literary Rhetoric. A Foundation for Literary Study. Brill. Leiden, 1998 (par ethopoiia u. c.).

Lenardon, R. J. The Saga of Themistocles. London : Thames \& Hudson, 1978.

Podlecki, A. J. The Life of Themistocles. A Critical Survey of the Literary and Archaeological Evidence. Montreal \& London, 1975.

Progymnasmata: Greek Textbooks of Prose Composition and Rhetoric. Trans. with introd. and notes G. A. Kennedy. Society of Biblical Literature, 2003.

Rosenmeyer, P. A. Ancient Epistolary Fictions: The Letter in Greek Literature. Cambridge University Press, 2001. Available: http://www.questia.com.

Rosenmeyer, P. A. Ancient Greek literary letters: Selections in translation. L., N. Y. : Routledge, 2006.

\section{Raksti grāmatās}

Попова, Т. В. Фиктивное письмо как литературный жанр (Поэтика образа героя, сюжета и жанра). Античная поэтика. Риторическая теория и литературная практика. М. : Институт мировой литературы имени А. М. Горького АН СССР, Наука, 1991, 181-216.

Миллер, Т. А. Псевдоисторическая эпистолография. Античная эпистолография. Очерки. М. : Наука, 1967, 192-226.

\section{Raksti periodikā}

Munro, J. Arthur R. The Chronology of Themistocles' Career. The Classical Review, Vol. 6, No. 8 (Oct., 1892), 333-334, Cambridge University Press on behalf of The Classical Association [cited 19 May 2009]. Available: http://www.jstor.org/stable/690533

Penwill, J. L. The Letters of Themistocles: An Epistolary Novel? Antichton. 1978, 12: 83-103.

\section{Nepublicēti materiāli (disertācijas, raksti)}

Koṇins, Igors. Ethopoeia pseidovēsturiskajā epistologräfijā (Temistokla cikls). Mağistra darbs. Rīga : LU, 2010. 
Igors Koṇins, Riga, Latvia

\section{IMAGE BUILDING IN ANCIENT RHETORIC AND PSEUDO-HISTORICAL LETTERS}

The article focuses on image-forming techniques in the collection of pseudo-historical of letters attributed to Themistocles. Themistocles'

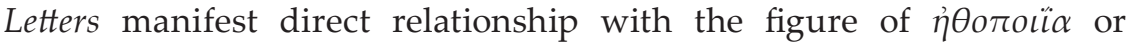
characterisation from the preparatory exercises or $\pi \rho \sigma \gamma v \mu v \alpha \alpha \mu \alpha \tau \alpha$ of rhetorical schools. Characterisation is analysed, comparing language features of the historical Themistocles to those in the letters. The main features were taken from scholarly literature. A conclusion is made that the letters can be divided into two groups, considering the author's opposite artistic goals. The goal of the first group is to reflect, in a hyperbolic form, the alter ego's anxiety about his life in exile. The anxiety is evidenced by a break of thought or the figure of hyperbaton and the vocabulary of suffering. Language features that fit Themistocles' proud character have been taken over from the testimony found in historical sources - the dominant use of the personal pronoun $\dot{\varepsilon} \gamma \omega \dot{\omega}$, setting his position off against the stand of his political opponents by using the principle of antithesis and use of verbs in the imperative form. In the second group of letters, features that fit Themistocles' proud character almost disappear, and, considering the author's artistic goal, reflect a person who calmly discusses the situation, sees the positive aspects of the opponents' actions, and is ready to do everything for his native country. 


\section{IEVA FĪBIGA}

Latvijas Universitāte, Latvija

\section{METAFORAS KOGNITİV Ā FUNKCIJA}

\section{(Galēna traktāts Par èdienu spēju)}

\section{İss kopsavilkums}

Tradicionāli ir radies priekšstats, ka zinātniskos tekstos tropi netiek lietoti. Taču tie, konkretizējot abstrakto, palīdz izzin,ā, līdz ar to zinātniskos tekstos tie nav neparasta parādība. Metafora ir viens no šiem tropiem. Zinātniskā valodā metafora izskaidro zinātnisko jaunradi.

Šāda zinātniskā jaunrade vērojama arī sengrieḳu ārsta Galēna tekstos, kas uzskatāmi par antīkās pasaules zinātniska teksta paraugu. Galēnam bija nozīmīga loma medicīnas attīstībā Senajā Grieḳijā. Tādējādi Galēna darbība devusi lielu ieguldījumu antīkās pasaules izglītības/izglītošanās $(\pi \alpha \iota \delta \varepsilon \dot{c} \alpha)$ gaitā. Šajā rakstā tiks atklāts, kāda ir metaforas loma traktātā Par ēdienu spēju.

Atslēgvārdi: Galēns, sengrieḳu medicīnas teksti, metafora, metaforas kognitīvā funkcija, izglītība.

Metafora tradicionāli tiek saistīta ar tēlainu valodu, tādu, kurā apzināts tropu un stilistisko figūru lietojums ir viens no galvenajiem papildinformācijas izteikšanas līdzekḷiem. Tāpēc ir radies priekšstats, ka zinātniskos tekstos papildinformācijas nav vai vismaz nevajadzētu būt, jo dominē pamatinformācija. Taču tropi, konkretizējot abstrakto, palīdz izziṇā, līdz ar to zinātniskos tekstos daži no tiem nav neparasta parādība. Metafora ir viens no šiem tropiem, kas ieṇem stabilu vietu zinātniskā valodā - tā izskaidro zinātnisko jaunradi. Šo procesu var dēvēt par inovācijas „saglabāšanu” (Fahnestock 1999, 4-6).

Šāda inovācijas „,saglabāšana” ar metaforas palīdzību vērojama arī sengrieḳu ārsta Galēna tekstos, kas uzskatāmi par antīkās pasaules zinātniskā teksta paraugu. Un šeit saskatāms Galēna ieguldījums antīkās pasaules izglìtības/izglītošanās $(\pi \alpha \iota \delta \varepsilon i \alpha)$ gaitā, jo medicīna Senajā Grieḳijā strauji attīstījās un Galēns spēja izskaidrot un nosaukt savus medicīniskos vērojumus tā, lai tie taptu saprotami gan ārstiem, gan ārstējamajiem. 
Senās Grieḳijas klasiskajā periodā (7.-4. gs. p. m. ē.) ārstēšanas māksla sāka kḷūt par zinātni, jo parādījās pirmie pētìjumi, veidojās terminologiija un pats galvenais - ārsti savas zināšanas aprakstīja traktātos. Par sen-

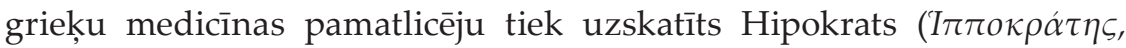
5. gs. p. m. ē.). Hipokrata mācība pāris gadsimtus būtiski nemainījās, līdz hellēnisma laikā mūsu èras 2. gadsimtā nozīmīgas izmaiṇas ieviesa Galēns no Pergamas (Gaile, van Hofa 2003, lii).

Galēns ( $\Gamma \alpha \lambda \eta v o ́ s, 129 .-216$. g. m. ē.) bija slavens ārsts, un viṇa mācība atstāja iespaidu uz turpmāko medicīnas attīstību Eiropā. Pats sevi Galēns uzskatīìis par filozofu, jo viṇa princips bijis, ka labam ārstam ir jābūt arī filozofam. Tāpēc viņa traktāti aptver ne tikai medicīnas jautājumus, bet arī logiiku, rētoriku un, protams, filozofiju. Galēns sekmēja vairāku medicīnas nozaru attīstību, ieskaitot anatomiju, fizioloǵiju, patoloǵiju, farmakoloǵiju, neirologiiju u. c. (Easterling, Knox 1989, 102-103).

Galēna praktiskā darbība veicināja medicīnas attīstību, savukārt traktātu rakstǐšana - medicīnas teorijas attīstību. Iedomājoties, kā pirms aptuveni diviem tūkstošiem gadu tika veikti pētījumi un novērojumi, kā veidojās jaunas zināšanas un kā tās tika pierakstītas, ir skaidrs, ka jaunatklājumi prasīja to skaidrošanu un nosaukšanu. Šim nolūkam tika izmantotas metaforas. Tāpēc, lūkojoties uz šiem tekstiem no mūsdienu viedokḷa, jāsecina, ka dažādi jaunatklājumi medicīnā tika aprakstīti, izmantojot metaforu. Jo metafora ir vārda, darbības vai aprakstoša termina pārnesums uz objekta atšķirīgu, bet līdzīgu jeb analogu formu, kas ir atbilstoši piemērota (OCCL 1962, 267).

Šajā rakstā metafora un tās kognitīvā funkcija tuvāk atklāta vienā

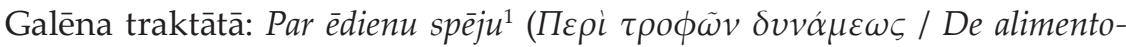
rum facultatibus). Sengrieḳu medicīnā traktāts iekḷaujams tēmā par ārstniecisko režīmu ( $\delta i \alpha \iota \tau \alpha)$, kad konkrētu ēdienu lietošana uzturā ir ne tikai enerǵijas gūšanas veids, bet arī ārstēšanas līdzeklis. Katram ēdienam ir sava spēja, kas ietekmē četru šķidrumu līdzsvaru organismā, līdz ar to ēdiens var būt neitrāls, labvēlīgs vai nelabvēlīgs kopējam veselības stāvoklim un atseviškiem orgāniem, var gan ārstēt, gan būt par cēloni kādai slimībai. Tāpēc traktāta sākumā Galēns uzsver tēmas svarīgumu, norādot, ka ikvienam ir būtiski izprast ēdiena iedarbību uz organismu. Tātad Galēns traktātu mērḳtiecīgi rakstījis kā izglìtojošu tekstu.

Senie grieḳi domāja, ka pasaulē valda četras stihijas: zeme, ūdens, gaiss un uguns. Mācība par četrām stihijām ieviesta arī medicīnā un tiek attiecināta uz cilvēka k̦ermeni. Valdīja uzskats, ka cilvēks ir iekārtots 
līdzīgi pasaulei - no tiem pašiem elementiem. No tā izveidojās kanonisko četru šķidrumu teorija: asinis $(\alpha \tilde{i} \mu \alpha)$, flegma $(\phi \lambda \dot{\varepsilon} \gamma \mu \alpha)$, dzeltenā žults ( $\chi \circ \lambda \eta ́)$ un melnā žults ( $\mu \varepsilon \dot{\lambda} \alpha \iota v \alpha \chi 0 \lambda \eta ́)$. Šie šķidrumi k̦ermenī ir līdzsvarā, un līdzsvara uzturēšanu nodrošina iekšejjais siltums (Gasparovs 2007, 194-196, 405).

Mācība par četrām stihijām vērojama arī Galēna traktātā Par édienu spēju, kad tiek runāts par k̦ermeṇa plūsmām, pūsmām, vēju u. tml.; elementi, kas raksturo dabu, pārnesti uz cilvēka k,ermen,i, skaidrojot tā uzbūvi un funkcionēšanu. Redzams, ka Galēns lieto metaforas, lai lasītājs vai klausītājs varētu izprast ēdiena nozīmi veselībā. Šāds antīkās pasaules zinātniskais teksts norāda, ka jaunatklājumi tika aprakstīti un tie bija pieejami ārstiem. Līdz ar to ārsti savā starpā lietoja metaforiskus apzīmējumus, kuri bija saprotami arī nespeciālistiem. Var apgalvot, ka šādi metaforiski apzīmējumi praksē labi strādāja, jo daḷa metaforu joprojām pastāv kā mūsdienu medicīnas termini.

Bet vēl pirms konkrētu metaforu piemēru aplūkošanas Galēna traktātā jāmin, kādas metaforu vispārīgās funkcijas tiek izšḳirtas:

1) nosaucējfunkcija jeb nominatīvā funkcija izmanto valodā esošus vārdus jaunu reāliju nosaukšanai, piemēram, koka sakne vai galotne, pārnestā nozīme - vārda sakne vai galotne;

2) izziṇas funkcija jeb kognitīvā funkcija spēj konkretizēt abstrakto; abstraktais nav tieši novērojams, bet ir izsecināms; konkrēts ir tas, ko var uztvert ar maṇu orgāniem, piemēram, esmu daudz ieguldījis šajā darbā vai tu izšķied manu laiku;

3) raksturojošā funkcija izpaužas tā, ka metafora izgaismo vienus parādības aspektus, bet apēno citus, piemēram, tauta ir aitu bars;

4) ietekmējošā funkcija liek par lietām domāt noteiktā virzienā, metaforas var mainīt uzskatus, piemēram, politika ir virtuve vai valsts ir kugóis. ${ }^{2}$

Zinātniskos tekstos vairumā gadījumu vērojama metaforas kognitīvā un nominatīvā funkcija. Tas attiecas arī uz šo Galēna traktātu.

Traktāts ir sadalīts trīs grāmatās, savukārt grāmatas sadalītas nodaḷās, un katrā no tām aprakstīts konkrēts ēdiens. Grāmatās vērojams logisks ēdienu dalījums: 1. grāmata veltìta graudaugiem, no tiem gatavotiem ēdieniem, pākšaugiem un visdažādākajām sēklām, 2. grāmata dārzeņiem, aug̣̣iem, ogām un riekstiem, bet 3. grāmata - gaḷas produktiem un subproduktiem, olām, piena produktiem, zivīm un jūras veltēm. 
Arī mūsdienās šāds produktu iedalījums (vien ar dažām nelielām izmain,ām) tiek izmantots uzturzinātnē.

Iespaidīgais produktu skaits, kas tiek aprakstīts, šḳiet, rāda, ka Galēns skrupulozi centies iekḷaut pilnīgi visu sava laika hellēnuu ēdienkarti. ${ }^{3}$ Un tā, skaidrojot, kā ēdiens iet cauri vēderam un kādu iespaidu atstāj uz veselību, Galēns apzināti vai nē izmanto metaforas, kas pilda kognitīvo funkciju.

Rakstā sniegti tikai spilgtākie un vairākkārt tekstā vērojamie metaforu piemēri. Varētu iesākt ar metaforām, kas palīdz izprast gremošanas sistēmu, tad pāriet pie metaforām par vēdera darbības traucējumiem un visbeidzot sniegt metaforu piemērus par vēdera izeju un organisma attīrǐšanos.

Gremošanas izpratnei Galēns lieto verbu $\pi \dot{\varepsilon} \tau \tau \omega$ - nogatavoties, adjek-

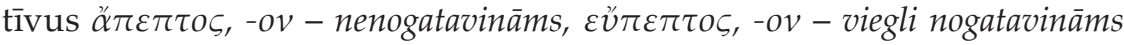
un $\delta \dot{v} \sigma \pi \varepsilon \pi \tau o \varsigma$, -ov - grūti nogatavināms, kā arī substantīvus $\varepsilon \dot{v} \pi \varepsilon \psi i ́ \alpha-$

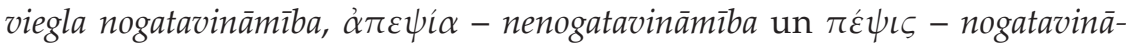
šana. ${ }^{4}$ Nogatavošanās ir process, kas raksturo, piemēram, augḷu vai labības nogatavošanos, bet Galēns to attiecina uz gremošanu - èdieni cilvēka organismā it kā nogatavojas. Interesanti, ka sākotnēji gremošanas process raksturots tieši ar šo verbu. Tāpat kā aug̣̣i vai labība pāriet citā, varētu teikt - pilnīgā fāzē, sniedzot vislabāko, tā arī ēdiens cilvēka organismā pārveidojas un sniedz nepieciešamās uzturvielas. Protams, ka vēlāk verbam $\pi \dot{\varepsilon} \tau \tau \omega$ vārdnīcā norādīta arī nozīme gremot, sagremot, bet tā jau vairs nav pamatnozīme. Ilustrācijai kāds piemērs no traktāta - par redīsiem rakstīts, ka svaigu redīsu ēšana uzlabo gremošanu: $\mu \varepsilon \tau \dot{\alpha}$ $\delta \varepsilon \tilde{\imath} \pi v o v$

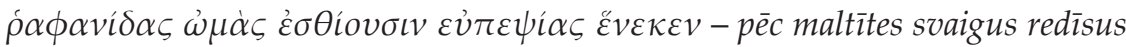
$\bar{e} d$ labas nogatavošanās nolūkā, t. i., labas gremošanas nolūkā (658. lpp.).

Neatñemama tēma, par kuru jārunā, kad tiek apspriests ēdiens un gremošanas orgānu sistēmas darbība, ir gremošanas traucējumi. Šeit Galēns runā par smaguma sajūtu, dedzināšanu, pūšanos, graizēm un aizsprostojumiem, skaidrojot šos traucējumus ar metaforu palīdzību. Šāds konstatējums attiecas ne tikai uz sengrieḳu medicīnu, bet arī uz mūsdienām, jo gadījumos, kad tiek runāts par vēdera darbības traucējumiem, neizmantojot medicīnas terminus, valodā nevilšus parādās arī metaforas.

Kunggì var rasties smaguma sajūta. Šìs sajūtas aprakstīšanai Galēns

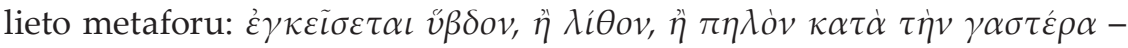
uzgūlies vai nu svins, akmens vai māli uz kunğga (459., 499., 518. lpp.) vai 


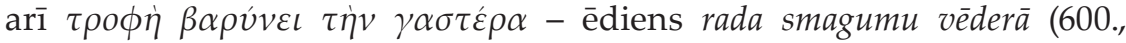
656. lpp.). Svins, akmens vai māli - Galēns neizšķir, kāda būtu šo „smagumu" atšķirība, taču skaidrs, ka visi ir blīvi, tādi, kurus kunggim grūti pārstrādāt. Arī pašlaik latviešu valodā nav svešs izteiciens - jūtos kā akmeni norijis vai kunğgi ir smaguma sajūta.

Kunği var nomocīt dedzināšana jeb, kā izsakās Galēns, košana:

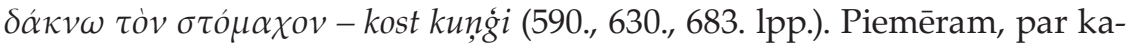

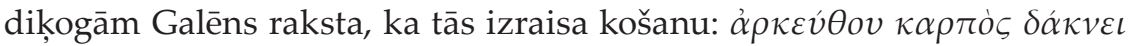

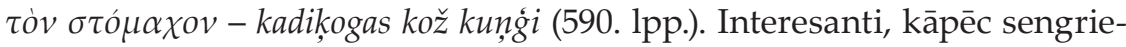
ķu valodā kož, bet latviešu - dedzina. Skaidrs, ka abi verbi līdzīgi ar to, ka norāda uz nepatīkamām sajūtām - palielinātu kuṇga skābes daudzumu. Sengrieķu verbs $\delta \alpha \dot{\kappa} v \omega$ nozīmē kost, dzelt, savukārt adjektīvs $\delta \alpha \kappa v \omega \dot{\delta} \eta \zeta_{\text {, }}$ $-\varepsilon \varsigma$, kam ir tā pati sakne, nozīmē dzēlìgs, dzelošs, kodīgs, ass, sìvs, sāpìgs. Šeit starp kost un dedzināt saskatāma saikne adjektīvā kodīgs, jo to var attiecināt gan uz kungga skābi, gan dūmiem. Un pēdējais ir saistīts ar dedzināšanu. Taču šis jautājums ir atsevišķi sīkāk pētāms, pašlaik izteikta tikai iespējamība.

Tālāk metaforas par vēdergraizēm. Kad vēdergraizes izraisījis

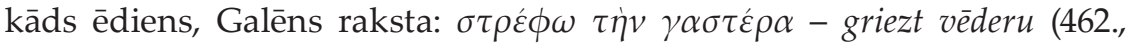

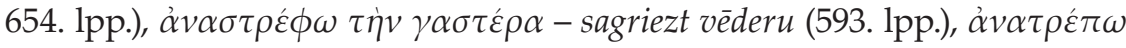

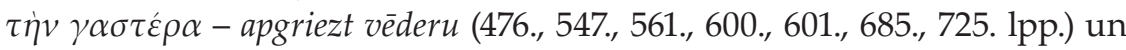

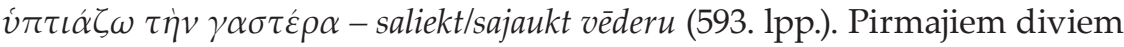
piemēriem pamatā ir verbs $\sigma \tau \rho \varepsilon \dot{\phi} \omega$ - griezt, pagriezt, pārnestā nozīmē mocìt. Arī pārējiem piemēriem ir līdzīga nozīme. Kopumā šeit iezīmējas līdzsvara izjaukšana - vēdera darbība tiek traucēta, it kā sagriezta ne-

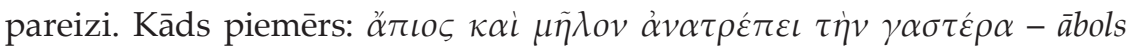
un bumbieris sagriež vēderu (600. lpp.). Arī latviešu valodā tiek izmantots izteiciens - sagriezies vēders, kas pamatā ir l,oti līdzīgs minētajām metaforām.

Vēl metaforas par vēdera pūšanos. Mūsdienu medicīnā tiek lietots termins pneimatoze. To jau izmantojis Galēns, un tā ir metafora:

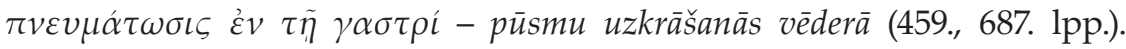
Tātad gāzu veidošanās zarnās. Te vērojams, kā viens no četriem dabas elementiem, t. i., gaiss, piemērots kāda konkrēta vēdera darbības traucējuma apzīmēšanai. Tāpat vēdera uzpūšanās gadījumā Galēns izmanto

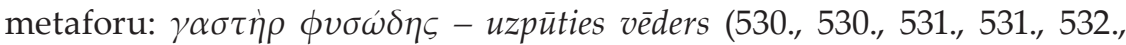
533., 534., 543., 545., 560., 649., 687., 687. lpp.). Kā redzams, šî metafora traktātā vērojama bieži, piemēram, 1. grāmatā nodaḷās par cūku/lauku 
pupām, par zirṇiem un par turku/auna zirṇiem. Šie visi ir ēdieni, kas izraisa $\gamma \alpha \sigma \tau \eta \rho \rho ~ \phi v \sigma \omega \delta \delta\rceil$ - uzpūtušos vēderu. Arī latviešu valodā bieži dzird sakām - uzpūties vēders, un šim jēdzienam arī ir pārnesta nozīme.

Spriežot par vēdera darbību, neizbēgami jārunā arī par vēdera izeju. Par to runā arī Galēns. Latviešu valodā jēdzienam vēdera izeja arī ir pārnesta nozīme, jo izeja ir ēkai, mājai u. tml., nevis vēderam. Vēdera izejas apzīmēšanai traktātā lietots daudz metaforu, kuru atšķirīiba ir niansēta, taču pamatā semantiski tās ir līdzīgas. Šāda niansēta atšḳirība parādās verbos, kas apzīmē kādu kustību uz leju vai cauri kaut kam un kas,

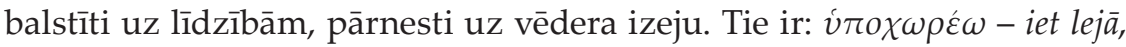

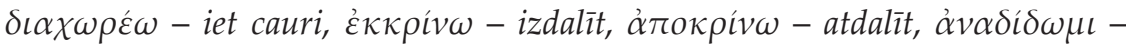

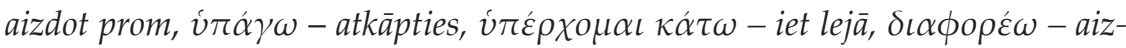

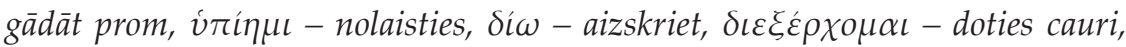

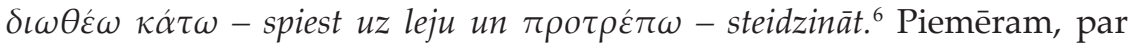
vīnogām rakstìts, ka tās baro mazāk nekā vìǵges, to labākā īpašìba ir spē-

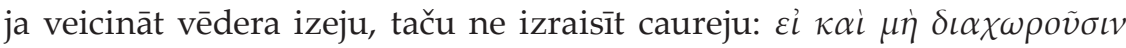
$\dot{\alpha} \xi \iota \lambda o ́ \gamma \omega \varsigma, \pi \varepsilon \phi \theta \varepsilon i ́ \eta \delta^{\prime} \dot{\varepsilon} v \tau \tilde{\eta} \gamma \alpha \sigma \tau \rho i \kappa \alpha \lambda \tilde{\omega} \varsigma$ - ja arī neiet cauri ievērojami, tad tomēr vēderā labi mīkstinās (574. lpp.). Vēl kāds piemērs par jaunieti, kas èdis skābenus ābolus un bumbierus un š̄ iemesla dēḷ cietis no

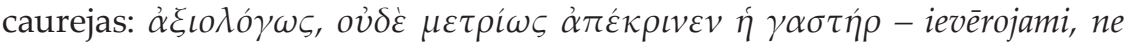
mēreni izdalījās vēders (599. lpp.).

Dažas metaforas norāda uz pastiprinātu vēdera izeju: $\delta \iota \alpha \rho j \rho \dot{\varepsilon} \omega-$ plūst cauri (597. lpp.), $\rho \dot{\varepsilon} \omega-$ plüst (596., 686. lpp.) un $\lambda \alpha \pi \alpha \zeta \zeta \omega-$ novadīt (458., 460., 598., 614., 614., 684. lpp.). Pirmajos divos piemēros skaidri redzams, kā ūdens kustība (ūdens - viens no četrām stihijām) attiecināta uz pastiprinātu vēdera izeju. Arī pēdējā piemērā tas vērojams - ūdens var kaut kur tikt novadìts. No verba $\delta \iota \alpha \hat{\rho} \rho \dot{\varepsilon} \omega-p l u \overline{s t}$

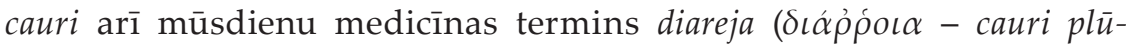

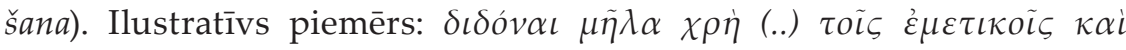

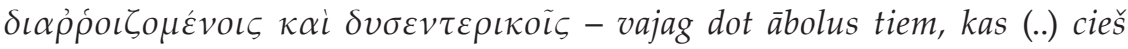
no vemšanas, cauri plūšanas un sliktām iekšām (597. lpp.). Līdz ar šādas metaforas izmantošanu lasītājam vai klausītājam ir saprotams, kāda ir šì vēdera problēma.

Traktātā ir ne tikai metaforas par vēdera darbību, bet arī par dažādiem procesiem organismā. Kad Galēns raksta par ēdienu spēju, protams, tiek pieminēti orgāni, slimības un procesi, kas norit organismā. Nākamajā metaforā atkal redzama ūdens kustība - tā pārnesta uz

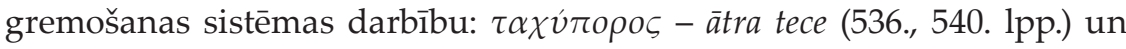




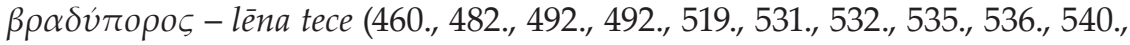
585., 596., 621., 676., 679., 680., 695., 706., 744. lpp.). Ar šīm metaforām raksturots zarnu trakta darbības àtrums - tas darbojas vai nu ātri, vai lēni. Latviešu valodā sakām līdzīgi par lēnu zarnu traktu - kūtras zarnas. Kāds piemērs no traktāta - attiecībā uz dzìvnieku aknu lietošanu uzturā Galēns uzsver, ka tās rada biezu šḳidrumu cilvēka organismā, ir grūti sagremojamas un līdz ar to palēnina zarnu trakta darbību: $\tau \dot{\jmath} \eta^{\eta} \pi \alpha \rho$

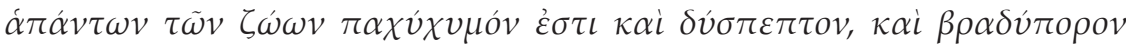
vтá $\rho \chi o v$ - visu dzīonieku aknas ir biezu šķidrumu radošas, grūti nogatavināmas un ar lènu teci (679. lpp.).

Tāpat kā ir nepieciešams tīrìt māju, tā arī organisms ir jāattīra, jo vielmain,as procesos rodas atkritumvielas, kas jāizvada. Šo procesu aprakstīšanai Galēns lieto metaforas par tīrīšanos: $\kappa \alpha \theta \alpha i ́ \rho \omega$ - tìrìt (596.,

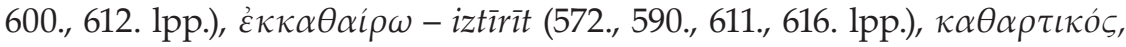

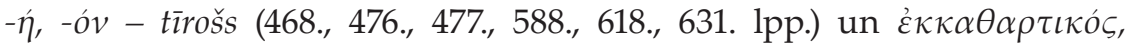
-óv - iztīrošs (547. lpp.). Tādējādi lasītājam vai klausītājam top skaidrs, ka vielmaiṇas procesu laikā organisms ne tikai gūst nepieciešamās uzturvielas, bet rada arī atkritumvielas, kuras jāiztīra. Kāds piemērs par pistācijām - tās sniedz maz uzturvielu organismam, taču veicina aknu darbību un iztīra tās no aizsprostojumu raisošiem šḳidrumiem:

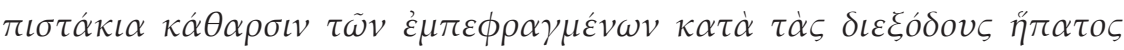
$\chi v \mu \tilde{\omega} v$ - pistācijas tīra aizsprostojumu raisošos šķidrumus no aknu izejas celiem (612. lpp.). Arī mandelēm ir tīroša spēja: $\dot{\alpha} \mu v \hat{\gamma} \delta \alpha \lambda$

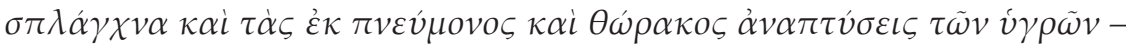
mandeles iztīra iekšèjās daḷas un no plaušām un krūtīm krēpas (611. lpp.). Atkritumvielu izvadīšana labas veselības nolūkos bijusi svarīga ne tikai Galēna dzīves laikā, tā ir aktuāla arī mūsdienās - ne velti bieži dzirdams vārdu salikums organisma attīì̌šana.

Vēl tīrīšanās apzīmēšanai Galēns izmanto metaforas: $\rho v ́ \pi \tau \omega-$ aiz-

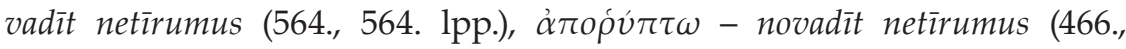

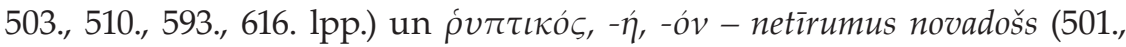
503., 509., 510., 530., 530., 532., 538., 547., 564., 571., 572., 584., 611., 628., 630. lpp.). Piemēram, par miežiem teikts, ka tiem ir gandrīz tikpat plašs izmantojums kā kviešiem, kvieši ir sildoši, bet mieži vairāk atvēsinoši. Kvieši rada biezu un lipīgu šḳidrumu organismā, taču mieži - plānu, t. i., šķidru, netīrumus novadošu: $\kappa \rho \iota \theta \alpha i \lambda \varepsilon \pi \tau \dot{v} v \kappa \alpha i$ $\rho v \pi \tau \iota \kappa o ̀ v ~ \gamma \varepsilon v v \tilde{\omega} \sigma \iota$

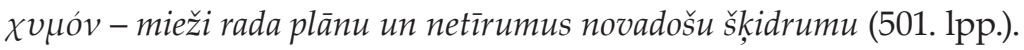




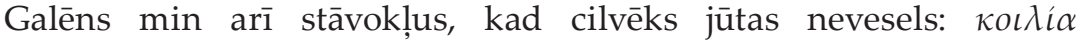
$\pi v \rho \omega ́ \delta \eta \varsigma$ - ugunīgas zarnas (692. lpp.), $\theta \varepsilon \rho \mu \tilde{\omega} v \pi \alpha \dot{\theta} \theta o \varsigma$ - karstumu nelaime

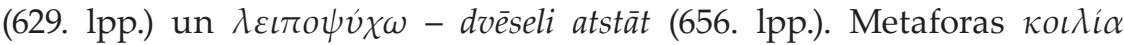
$\tau v \rho \omega \dot{\delta} \eta \varsigma$ - ugunīgas zarnas un $\theta \varepsilon \rho \mu \tilde{\omega} v \pi \dot{\alpha} \theta o \varsigma$ - karstumu nelaime rāda divu veidu iekaisumus. Pirmais ir iekaisums zarnās, un Galēns to piemin, rakstot par biezpienu - tas ir vēss un rada biezu šķidrumu, tāpēc to ieteicams ēst tiem, kam iekaisums zarnās, jo biezpiena vēsums neitralizē karstumu, kas radies iekaisuma dēḷ (692. lpp.). Otrais ir ādas iekaisums. Nodạ̣a par malvām Galēns norāda, ka to sula ir lipīga un atvēsinoša, tāpēc to var likt kā kompresi uz ādas iekaisumiem (629. lpp.). Abas metaforas norāda uz pārmērīgu karstumu kādā konkrētā ḳermeṇa daḷā. Te atkal redzams, kā uz organismu attiecināta viena no četrām stihijām - uguns. Latviešu valodā leksēmai iekaisums arī pamatā ir verbs, kas saistās ar karstumu un uguni - kaist.

Savukārt metafora $\lambda \varepsilon \iota \pi o \psi v ́ \chi \omega$ - dvēseli atstāt vērojama nodaḷā par sēnēm. Sēnes rada aukstu flegmu, un tās ir pareizi jāpagatavo, lai neradītu kaitējumu. Pretējā gadījumā kunggì rodas smaguma sajūta, sākas krampji, ir apgrūtināta elpošana, auksti sviedri un cilvēks var

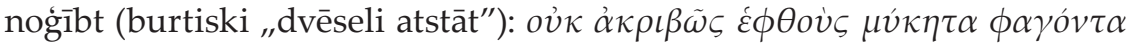
(..) $\lambda \varepsilon\llcorner\pi о \psi v \chi \eta ் \sigma \eta \tau \alpha \iota-\bar{e} d o t$ nepareizi pagatavotas sēnes, (..) var dvēseli atstāt (656. lpp.).

Kā jau minēts, traktāts ir plašs, un šīs nav vienīgās tajā vērojamās metaforas. Dažkārt Galēns vienas un tās pašas metaforas lieto gandrīz ikvienā nodaḷā. Šāds novērojums rāda, ka dažas no metaforām nav izmantotas nejauši un tās kalpojušas kā nostabilizējušies jēdzieni. Svarīgi arī, ka daḷa aprakstīto metaforu līdzīgi lietotas latviešu valodā.

Medicīna Senajā Grieķijā bija zinātne, kas vēl tikai attīstìjās, tāpēc loǵiski, ka pārtikas produktu sastāvs, gremošanas sistēmas darbība, slimību cēloṇi un pats cilvēka k̦ermenis līdz galam nebija izprasts. Tādējādi tas, kas sengrieḳu medicīnā bija neskaidrs jeb abstrakts, tika konkretizēts. Kā jau minēts, konkrētais ir tas, kas ir skaidri novērojams un ko var uztvert ar maṇu orgāniem. Tieši tas arī parādās sniegtajos metaforu piemēros - abstraktais tiek skaidrots ar cilvēkam raksturīgām darbībām un īpašỉbām un nedzīviem elementiem. Tā traktātā vērojamas metaforas, kas pilda kognitīvo funkciju.

Šeit arī saskatāms Galēna devums izglītības/izglītošanās ( $\pi \alpha \iota \delta \varepsilon i \alpha)$ gaitā - tas, kas nebija zināms par ēdiena iedarbību uz organismu un daudzām citām traktātā skartajām tēmām, tika izskaidrots ar 
vienkāršām darbībām vai lietām. Tādējādi tiek sasniegts traktāta mērķis - lasītājs vai klausītājs ir kḷuvis kādā jomā izglītotāks: šajā gadījumā èdiena iedarbības jomā. Tātad metaforas loma ir izglītojoša.

Galēna traktātā Par êdienu spēju izteiktie vispārīgie apgalvojumi, norādījumi, novērojumi un ieteikumi par ēšanas režīmu nav zaudējuši kvalitāti arī mūsdienu medicīnā. Protams, ir aspekti, kas, medicīnai attīstoties, mainījušies un ir apstrīdēti, taču pamatdoma par ēdiena nozīmi cilvēka veselībā palikusi. Arī svarīgākā atziņa par cilvēka veselību nav mainījusies - pareizs ēšanas režīms ir veselības pamats.

\section{ATSAUCES}

1 Līdz šim Galēna traktāti nav tulkoti latviešu valodā, tāpat arī traktāts Par èdienu spēju; turpmāk pieminētie metaforu piemēri no traktāta ir autores tulkojums latviešu valodā; oriğinālteksts no grāmatas Claudii Galeni Opera Omnia, 1823, 453.-748. lpp. Šis Galēna traktāts ir tulkots gan angḷu (On the Properties of Foodstuff), gan vācu valodā (Über die Kräfte der Nahrungsmittel). Tas ir viens no Galēna vispusīgākajiem un plašākajiem traktātiem, kas, iztulkots latviski, veiksmīgi papildinātu antīkās literatūras klāstu.

2 Vairāk par metaforas funkcijām sk. Lee, D. Cognitive Linguistics: an Introduction, 2001; Ungerer, F., Hans-Jorg, S. An Introduction to Cognitive Linguistics, 2006; Lakoff, G., Jonson, M. Metaphors we live by, 2003; Kovecses, Z. Metaphor: a Practical Introduction, 2010.

3 1. grāmata: par kviešiem, par konditorejas izstrādājumiem, par kūkām/sacepumiem, par baltmaizi, par putraimiem, par ūden⿳亠 vārītiem kviešiem, par cieti, par miežiem, par miežu maizēm, par miežu èdieniem, par miežu kūkām/sacepumiem, par savvaḷas kviešiem, par auzām, par prosu, par pākšaugiem, par rīsiem, par lēcām, par pupiņām, par cūkullauku pupām, par zirņiem, par turkulauna zirn̦iem, par lupīnu sēklām, par sierāboliṇa sēklām, par pākšu pupām un šḳeltajiem/ dzeltenajiem zirn̦iem, par sējas dedestin̄ām, par savvaḷas sējas dedestinām, par hiacinšu pupām, par rūgto vīķu sēklām, par sezama sēklām un rukolas sēklām, par magoņu sēklām, par linsēklām, par salvijas sēklām, par kan̨epju sēklām, par parastā viteksa sēklām, par nezāḷ un [citu] vīku sēklām un par dažādu sēklu krustojumiem. 2. grāmata: par sezonālajiem augḷiem, par ķirbi, par melonēm, par arbūziem, par gurķiem, par aug̣ılkokiem, par vīğèm, par vīnogām, par rozīnēm, par zìdkoka ogām, par k̦iršiem, par kazenāju ogām, par mežrozī̌su aug̣iem, par kadiķogām, par ciedra augliem, par priežu čiekuriem, par mirtes ogām, par persikiem, par aprikozēm, par āboliem, par iemeslu, kāpēe skābeni āboli un bumbieri izraisa caureju, par cidonijām un vilkābel̦u aug̣̣iem, par bumbieriem un granātāboliem, par mespila aug̣̦iem un pìlādžogām, par datelèm, par olīvām, par valriekstiem, par mandelēm, par pistācijām, par plūmēm, par hohobas ogām, par ceratonijas augliem, par kaperiem, par sikamoras aug̣liem, par hurmu, par citronu, par savvaḷas augu augliem, par èdieniem no dažādām dārzeņu dal̦ām, par salātlapām, par cigoriniem, par malvu, par bietēm, par kāpostiem, par zemeņu balandu un därza balodeni, par portulaku, par skābenēm, par zirgskābenēm, par bebrukārklinu, par èrkškainiem augiem, par seleriju, savvaḷas seleriju, Krētas seleriju un pastinaku, par sējas pazvērìti, par nātrēm, par kresi un savvaḷas kārveli, par baziliku, par fenheli, par sparǵel̦iem, par asniem, par èdamo augu daḷ atšķirìbām, par rācen̦iem, par kallām, par ārumu, par asfodeli, par muskariem, par burkānu, suņuburkšǩi un ķimeni, par trifelèm, par sēnēm, par redīsiem un par sīpoliem, ķiploku, puraviem un lakšiem. 3. grāmata: par èdienu no sauszemes dzīonieku gaḷas (ne tikai mājlopu, bet arī zaḳu, suṇu, kamieḷu, lāču u. c. dzīvnieku gal̦as), par gliemežiem, par sauszemes dzīonieku perifērajām daḷām (t. i., ausis, kājas, šnukurs), par mēli, par dziedzeriem, par sēkliniekiem, par smadzenēm, par kaula 
smadzenēm, par muguras smadzenēm, par mīkstajiem un cietajiem taukiem, par sauszemes dzīvnieku iekšām, par četrkājainu kuṇgì, dzemdi un zarnām, par mājlopu un savvaḷas dzīonieku atšķirībām, par pienu, par biezpienu, par sieru, par mājlopu asinīm, par édienu no putnu gaḷas, par zosìm un strausiem, par putna dal̦u atškirībām, par olām, par putnu asinīm, par édienu no jūras veltēm, par pelēko kefali, par jūras asari, par barbi, par akmens zivi, par grunduli, par zivīm ar mīkstu gaḷu, par stingras galas zivīm, par to, vai visi stingri édieni rada sālas sulas pēc novārī̌sanas, par moluskiem, par vēžveidīgajiem, par galvkājiem, par skrimšlı zivīm, par milzu zivīm, par jūras ežiem, par medu, par vīnu, par marinētiem èdieniem un par neitrāliem èdieniem.

4 Minētajiem metaforu piemēriem netiks norādītas konkrētas lappuses, kurās tie parādās, jo tie traktātā ir gandrīz katrā nodaḷā; kopumā metaforas par nogatavošanos vērojamas 164 reizes.

5 Šeit leksēma $\gamma \alpha \sigma \tau \eta \dot{\rho}$ - vēders latviešu valodā tiek tulkota kā kuṇgíis, lai gan citos metaforu piemēros tā tiek tulkota kā vēders; Galēns tekstos šo abu leksēmu lietošanā neievēro konsekvenci.

6 Minētajiem metaforu piemēriem netiks norādītas konkrētas lappuses, kurās tie parādās, jo tie traktātā ir gandrīz katrā nodaḷā; kopumā metaforas par vēdera izeju vērojamas 94 reizes.

\section{BIBLIOGRĀFIJA}

Claudii Galeni. Opera Omnia. Kuhl, D. C. G. (Ed.). Lipsiae : Teubner, 1823, 453-748.

Easterling, P. E., Knox, B. M. W. The Cambridge History of Classical Literature. The Hellenistic Period and the Empire. Vol. I, Part 4. Cambridge : Cambridge University Press, 1989.

Fahnestock, J. Rhetorical Figures in Science. New York - Oxford : Oxford University Press, 1999.

Gasparovs, M. Aizraujošā Grieķija. M. Poḷakovas tulk. no krievu valodas. Rīga : Jānis Roze, 2007.

Hipokratiskie raksti. Izlase. A. Gailes, A. van Hofas tulk. no sengrieḳu valodas. Rīga : Liepnieks un Rītups, 2003.

The Oxford Companion to Classical Literature (OCCL). Harvey, P. (Ed.). Oxford : Clarendon Press, 1962.

Thesaurus Linguae Graecae. A Digital Library of Greek Literature, Irvine, CA : University of California, 2001 [cited 17 August, 2012]. Available: http://www.tlg.uci.edu/about/

Valodniecības pamatterminu skaidrojošā vārdnīca. Red. V. Skujiṇa. Rīga : LU Latviešu valodas institūts, 2007.

Ieva Fībiga, University of Latvia, Latvia

THE COGNITIVE FUNCTION OF METAPHOR (GALEN'S TREATISE ON THE PROPERTIES OF FOODSTUFFS)

Traditionally, there exists an opinion that there are no stylistic figures in the language of science. However, by specifying the abstract, tropes help in cognition, thus they are not that uncommon in scientific texts. Metaphor is one of such tropes. Metaphor explains a scientific innovation in the language of science. This process may be called "preserving of the innovation". 
This "preserving" with the help of metaphor is observed in Ancient Greek physician Galen's texts, which are considered to be exemplary scientific texts of the Classical Antiquity. Medicine rapidly developed in Ancient Greece, and Galen had an important role in this process. Galen's activities have contributed significantly to the progress of education/ learning $(\pi \alpha \iota \delta \varepsilon i \alpha)$ of the antique world.

This paper aims to uncover metaphor and its cognitive function in

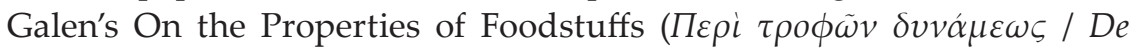
alimentorum facultatibus). The cognitive function of metaphor can concretize the abstract; in this way Galen can explain medical observations with the help of simple actions and things for both doctors and nonspecialists to understand. Thus we may conclude that metaphor has an educational role. 


\section{GEORGIOS THEOTOKIS}

Fatih University, Istanbul

\section{FROM ANCIENT GREECE TO BYZANTIUM: STRATEGIC INNOVATION OR CONTINUITY OF MILITARY THINKING?}

\section{Brief summary}

This paper will attempt to address a key question asked by eminent modern historians regarding the influence of the Greek and Latin military treatises of the $1^{\text {st }} \mathrm{c}$. AD on the development of the strategic thinking of the Byzantines and ask whether these manuals become archaic, valued as literary pieces rather than real handbooks, or rather they are consciously adapted to the geo-political reality of the time by contemporary theoreticians of war.

Keywords: tactics, strategy, war, manual, adaptation, army, battle-formation, Frontinus, infantry, cavalry, Rome, Byzantium

The so-called Strategika or Taktika are a specific category of literary works written for officers of the army that contained constitutions and treatises of military nature which have been compiled by the author through personal experience or through oral tradition and other literary works of the past. The first known work of this kind comes from the $4^{\text {th }}$ c. BC by a certain Aeneas, while numerous such works from the Byzantine period have also been saved. This paper will attempt to address a key question asked by eminent modern historians like John F. Haldon, Walter E. Kaegi and others regarding the influence of the Taktika to the strategic thinking of the Byzantines. ${ }^{1}$ More specifically, we read in Kaegi's article: "The Byzantine strategic thinking was not born ex nihilo but it was rather the conscious imitation and adaptation to the ancient Greek military writings and recommendations of the Greek classical period, and more specifically Aeneas Tacticus (357-56 BC) or even older ones, and to similar literary works of the Roman period - like Frontinus (end of the $1^{\text {st }}$ c. AD), Onasander (around 59 AD), Aelian (106 AD), Polyaenus (163-65 AD), and others - who translated and adapted those ancient writings to the strategic thinking of their period." 
By putting the authors of the Strategika of the $1^{\text {st }}$ and $2^{\text {nd }}$ centuries AD in centre stage, this paper will attempt to examine the validity of the aforementioned point through the examination of the links that can be found between the sources used by our authors, the role of language in this procedure, and the similarities in the aim, scope and structure of the works, and thus come to some conclusions regarding their objectivity and value as historical sources for the art of war. Finally, I will attempt to compare the content of the Ancient Greek, Roman and Byzantine Taktika in a number of points like: the way each author perceived the terms Strategy and Tactics and how did these terms evolve through the centuries, and what information we draw for the recruitment, training and discipline of the soldiers, division of an army into units, its equipment and its basic battle-formations.

The aforementioned military manuals that can be dated back from Antiquity to the Late Roman and Middle Byzantine period are, perhaps, the greatest primary source for a military historian, as they contain centuries of knowledge in military affairs and advices that vary considerably from battlefield formations and tactics to stratagems applied by famous personalities of the past, like Alexander the Great or Julius Caesar. They are a specific category of literary works that began to appear in Ancient Greece around the end of the $5^{\text {th }}$ century BC under the influence of the sophists and Socrates and carried on well into the Roman and Byzantine periods. At this point we can trace an important difference between the Byzantines - and the Greeks and Romans before them - and their enemies (like the Muslims): the former were writing down and codifying their knowledge in military affairs, a fact that has created the false impression that the enemies of the Byzantines were inferior to them in the Art of War simply because there are less Muslim military treatises that have survived to this day.

The first of the Taktika dates back to 357 BC and was written by a certain Aeneas, also known as Taktikos, an experienced soldier ${ }^{2}$ in operational theatres in Peloponnesus and Asia Minor who wrote -

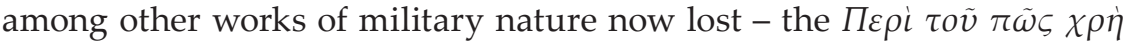

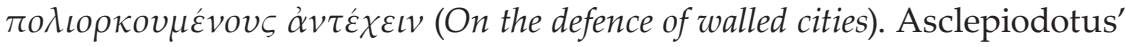
TÉ $\chi v \eta T \alpha \kappa \tau \iota \kappa \eta$ is also one of the earliest works on military matters, written in the $1^{\text {st }}$ century BC; however, much better known to the Byzantines was the $\Sigma \tau \rho \alpha \tau \eta \gamma \iota k o ́ s$ (General) of Onasander, a Platonic philosopher writing around $59 \mathrm{AD}$, whose work examines the several duties and 
responsibilities of a general. His work greatly influenced the Byzantine authors of Strategika and, especially, the Emperor Leo VI (c. 900). ${ }^{3}$ An author who exercised great influence on the future generations of military writers was Aelian, a Greek living in Rome in the early $2^{\text {nd }}$ century AD who based his Tactical Theory on the art of war developed in the Hellenistic period, having the Macedonian phalanx as his model. Another Greek living in Rome in the $2^{\text {nd }}$ century AD was Polyaenus, whose $\Sigma \tau \rho \alpha \tau \eta \gamma \eta \mu \alpha \tau \alpha$ a collection of 900 stratagems of famous people, like Pericles and Leonidas - is an invaluable primary source, as a great part of the information we get from it is unique. ${ }^{4}$

There are only two such works that have been saved in Latin, written some three centuries apart. First, we have Sextus Julius Frontinus' Strategemata, another collection of stratagems from the Ancient Greek and Roman period compiled by an experienced officer and civil servant of the Roman State between the years 84-96 AD. The other is Publius Flavius Vegetius Renatus' Epitoma Rei Militaris, dated between the years 383-450 AD. It is the only work of its kind in western Europe until Machiavelli's Dell' Arte Della Guerra (1521), and it presents an idealized version of the organization, battle-tactics, armament and training of the Roman Army of the $4^{\text {th }}-5^{\text {th }}$ centuries AD.

Although a large corpus of Byzantine military literature has survived, the length of this paper does not allow me to examine them in detail. Byzantine manuals were first produced in the sixth century, with the most well-known being the Strategikon attributed to Emperor Maurice (582-602 AD), a work compiled early in the $7^{\text {th }}$ century that dealt with the operational matters of the Roman Army. ${ }^{5}$ The Strategikon not only uses elements from previous works but also contains some original and up-to-date material - mostly regarding the enemies of the Empire. These works greatly proliferated in the tenth century, when the Byzantines embarked on their conquests in the East and the Balkans, with the "mass production" of at least six major works of this kind, like Nicephoros Phocas' Praecepta Militaria (c. 969).

To build up my argument, first let me begin with the definition of the term Taktika that has already been given at the beginning of this paper: "Strategika or Taktika are a specific category of literary works that contained constitutions and treatises of military nature which have been compiled by the author (a) through personal experience and/or (b) through oral tradition and other literary works of the past." I have 
pointed out the fact that a great number of these authors had served as army officers at some point in their lives; indeed, Aeneas Tacticus had seen action in Peloponnesus and in Asia Minor in the mid- $4^{\text {th }}$ century BC, Frontinus was the military commander of Roman Britain between 74-78 AD with military experience in south Wales, while the author of the Strategikon can probably be identified with Philippicos, the general (magister) of the Imperial Forces in the East (the late $6^{\text {th }}$ century). However, although many of these works contain a great number of original and innovative ideas, indeed none of these authors was as great a military tactician as the personalities whose exploits they examine in their works, like Pericles, Alexander the Great, Scipio, or Julius Caesar. The value of these works lies in the fact that they are a great source material for the military knowledge of the Ancient Greeks and the Romans which their authors have gathered, organised and enriched through the centuries, thus transmitting it to the future generations of army officers and civil servants. Indeed, I have already mentioned the tradition of codifying the military traditions and knowledge that the Byzantines had inherited from Greece and Rome along with their authority in military matters which they revered. But what, exactly, were the written sources of our authors and what similarities we can detect in the contents of the Taktika throughout the centuries?

If we take as a starting point the first - chronologically - of our military works: Aeneas Tacticus seems to have been drawing extensively from both his experience as a general and the oral tradition that had survived to his time, making occasional use of Herodotus, Thucydides, Xenophon and - one of the greatest Athenian generals of the early $4^{\text {th }}$ century BC - Iphicrates. ${ }^{6}$ The fact that Aeneas' work was highly regarded in Antiquity is shown by the fact that early in the next century Cineas, a Thessalian and a close associate of another brilliant general and tactician, king Pyrrhus of Epirus, compiled an epitome of them, undoubtedly with the suggestion of the latter. In the second half of the $3^{\text {rd }}$ century BC the fifth book of Philo the Mechanicus on the attack and defence of fortifications makes use of Aeneas' work, ${ }^{7}$ while Polybius (200-118 BC) also identifies a certain Aeneas, "ó $\tau \dot{\alpha} \pi \varepsilon \rho \dot{i} \tau \tilde{\omega} v$

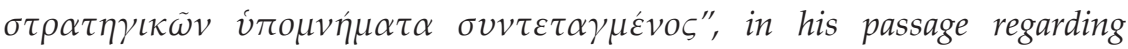
signal fires. ${ }^{8}$ Thus, the historical connection between the On Defence and the authors of the $1^{\text {st }}$ and $2^{\text {nd }}$ century AD can be built through the use of common sources. Following the same trail of thought, we know 
that Onasander had made use of Homer, Herodotus and Thucydides, and both he and Aelian (who was writing in 106 AD) seemed to have admired and followed Xenophon, Iphicrates and Polybius. In fact, Aelian classified Aeneas in the preface of his Tactics as "the first military writer who composed $\Sigma \tau \rho \alpha \tau \eta \gamma \iota \kappa \dot{\alpha} \beta \iota \beta \lambda i \alpha$ i $\alpha \alpha v \alpha,{ }^{\prime \prime}$ while another of his great sources was Frontinus who he had actually met in person and would certainly have influenced his work.

To establish the link between the ancient authors of Taktika and those who wrote in Latin is a much more difficult matter altogether. The major hurdle to overcome is, of course, the language in which the authors could read and write! Frontinus had made use of two main sources: primarily (a) Titus Livius (59-17 BC), who wrote the famous Ab Urbe Condita Libri, and (b) Valerius Maximus, a writer and a rhetorician who lived during the reign of Emperor Tiberius (14 - 37 AD). Both Livius and Maximus, however, are using Cicero and Polybius as their main sources, thus the latter could possibly have been the historical link between our Latin authors and Aeneas Tacticus. Another theory that has been put forward by N. P. Milner wants Frontinus to have had indirect access to Aeneas Tacticus through the work of Onasander, based on the common structure and the similarities in the contents of their works. ${ }^{10}$ But the language barrier, once again, makes this theory less attractive. What is certain, however, is Frontinus' influence on the work of Vegetius, as the latter not only identifies the former two times in his work (I. 8, II. 3) but it is quite likely that Vegetius' third and fourth books are drafted after the Strategemata.

The Byzantines, thus, inherited a voluminous series of military treatises from Antiquity - works which examined, summarized and gave useful advice regarding several military matters - from the training of new recruits to besieging a city and how to manoeuvre an army in rough terrain. As it has been highlighted already, the Byzantines revered the authority of the Greeks and the Romans and their wish to transmit the "ancient" knowledge in military matters to the future generations of army officers is more than obvious in their work.

We have resolved, therefore, to do some writing on this subject [Tactical theory], as best as we can, succinctly and simply, drawing in part on ancient authors and in part on our limited experience of active duty. In so doing we make no pretence of breaking new ground or of trying to improve upon the ancients, who, in their writings, were addressing knowledgeable and experienced men. ${ }^{11}$ 
What we have taken up from those sources [ancient authorities] has been gathered into what we have said here [Constitution regarding commands and movements for drill], along with what we have derived from the experience of more recent authorities... ${ }^{12}$

This becomes more apparent if we consider that all of them were compiled in a period of intense military activity, when the Empire was either on the defensive (the $7^{\text {th }}$ century for the Strategikon and the early $10^{\text {th }}$ century for the Taktika) or was marking an era of offensive warfare (the wars of reconquest in the East, after the 960s). Finally, two facts have to be underlined at this point. First, the Byzantine authors of Taktika drew their material largely from the ancient Greek and Roman authors already mentioned, although none of them is specifically mentioned, largely because of the ancient tendency to suppress the names of the more immediate sources or to copy authors unnamed. A rare exception to this is Leo VI who identifies Arian, Aelian and Onasander several times in his Taktika (VI. 25/VII. 67). Second, we have to understand that the Byzantine authors were not simply copying or summarising their predecessors' works, nor were they attempting to write a manual that looked back to past eras of glory, like Vegetius did. Rather, they took the essence of the teachings of the ancients in the Art of War - their way of thinking and their understanding of warfare and its basic principles, like order $(\tau \dot{\alpha} \xi \iota \varsigma)$, discipline and command structure - and adapted it to the geopolitical reality of their time, and they enriched it in a practical and comprehensive manual of war.

The fact that these Byzantine treatises were compiled in periods of intense military activity for the Empire can help to explain their aim and scope. We read in the Strategikon: "The state of the armed forces has been neglected for a long time and has fallen so completely into oblivion, so to speak, that those who assume the command of troops do not understand even the most obvious matters and run into all sorts of difficulties." 13 This passage falls into the wider category of writings from authors who seemed to be extremely worried about the neglect and decay in the armed forces during their period of writing and for the dangers about to befall the Empire; and, we have our authors' answer:

A modest and elementary handbook or introduction for those devoting themselves to generalship, which should facilitate the progress of those who wish to advance to a better and more detailed knowledge of those ancient tactical theories. ${ }^{14}$ 
Also, we read: "We must, therefore, recover the ancient custom from histories and books ... the Spartans, it is true, and the Athenians and other Greeks published in books much material which they call Taktika." 15 Thus, it is through the urgent need to compile practical military manuals for contemporary army officers that the knowledge of the ancients in military matters has been saved.

A similar attitude to educate contemporary officers applies to all the Taktika of the $1^{\text {st }}$ and $2^{\text {nd }}$ centuries as well. I put here some characteristic extracts from these works:

For in this way [writing about military matters] commanders will be furnished with specimens of wisdom and foresight, which will serve to foster their own power of conceiving and executing like deeds. There will result ... a general will not fear the issue of his own stratagem, if he compares it with experiments already successfully made. ${ }^{16}$

My work will be a school for good generals and an object of delight for retired commanders in these times of peace ... for the expedients they [Romans] used in order to avoid suffering harm and the means by which they contrive to inflict it, all this I have collected. ${ }^{17}$

This last section of the paper will attempt to complete building the argument for the transmission of "military" knowledge from Antiquity to Byzantium by comparing the structure and the most important extracts from the contents of the Taktika. First, historians have identified a similar division of the works in three major thematics according to the variety of the subject-matter, with the focal point being the battle itself, thus referring to the events prior to the battle, which involved the training, logistics, morale etc., those that deal with the battle itself and the parameters that could affect its outcome, and those following the aftermath of the battle - most usually concerning the retreat of an army or a siege of a stronghold. Although the most clear-cut structural division of this kind can be found in Frontinus' Strategemata, other authors of Taktika have followed the same pattern: namely, Onasander, Vegetius - for whom we have already stressed the fact that he was greatly influenced by Frontinus, while the same thematic structure can be seen in Leo VI's Taktika and the Strategikon, where the author of the latter work is dealing with the recruitment, training, equipment and battle formation before going on to examine what should be observed on the day of the battle and on its aftermath. 
In the first book of Frontinus' Strategemata that deals with the events before the battle, we can identify four more sub-categories concerning (a) strategy and the general planning of the war, (b) the marching of the army in friendly and enemy territory, (c) the defeat of the enemy by cunning and, (d) the morale and discipline of the troops. In this first section, Frontinus differentiates between the two kinds of strategy that can be followed by a general - either an offensive strategy or a defensive one - depending on the numbers of men involved, the morale of the army, the terrain, the gains etc. These factors are examined in detail by the Epitome of Vegetius, the Strategikon and the Taktika of the Byzantines, and the similarities are more than obvious to the careful eye. ${ }^{18}$ Strategy was altogether important for a general of the Greek, Roman and Byzantine period, and, although the terms Strategy and Tactics were not differentiated until the $18^{\text {th }}$ century, what is clear from our treatises is the spirit of avoidance of battle and the defeat of the enemy by stratagems, bribery and other cunning means.

An important aspect of the preparation for war was intelligence! The gathering of as much information as possible for the enemy was paramount for all authors of Taktika since Antiquity, and the concealment of the tactical plans was equally crucial. Characteristically, in case an informant is discovered in the military council, a general should pretend that he is afraid of the things he desire, in order to give the false impression to the enemy that this would be the right strategical move against his army.$^{19}$ Further, the dispatch of soldiers dressed as slaves or envoys, wearing the local outfit and speaking the local language/dialect to enter the enemy town and inspect the fortifications and report on the enemy numbers is highly recommended. ${ }^{20}$ Also, every author places great importance in escaping from difficult situations, like the crossing of a river when an army is at its most vulnerable, ${ }^{21}$ and an attack when peace negotiations are taking place is also favourite amongst many. ${ }^{22}$ The placing of captured enemy soldiers as a screen to the line of march is proposed for leading an army through dangerous enemy territory. ${ }^{23}$ And, since good morale of the troops was very important for a general, all the Taktika provide many examples on how to dispel the fears inspired by adverse omens, like meteors or thunderbolts, and how to arouse the army's enthusiasm for battle by convincing them that the Gods were on their side. ${ }^{24}$

The second book of Frontinus deals with the events on the day of the battle, with the first half examining key issues, such as the time and 
place to offer a battle and numerous battle formations, where the author provides examples from Antiquity. In Addition, stratagems on how to cause panic in the ranks of the enemy and escape encirclement are also presented. It seems to be common amongst our authors to recommend an attack on the enemy army around noon, ${ }^{25}$ and more specifically during lunch-time, and there is also a direct correlation between the opposing numbers involved in the battle, the armies' consistency (cavalry, foot and chariots) and the terrain that should be chosen to give battle. ${ }^{26}$ A very significant factor which certainly determined the outcome of the battle was the formation of the opposing armies which depended on the numbers and their composition, the terrain etc. The basic principle underlined by Frontinus was to gather adequate intelligence as to take advantage of the weakest points in enemy's formation and turn those against themselves - there are many common elements here with the writings of Aelian, Vegetius and Leo VI. Our author also presents a number of formations used by famous generals of Antiquity, like Scipio, Alexander the Great and Pyrrhus. It is worth mentioning that Alexander's formation at Gaugamela: "aciem in omnem spectantem ordinavit, ut circumventi undique pugnare possent," in essence a double-faced formation, bears many similarities to the infantry formation introduced in the mid- $10^{\text {th }}$ century AD by the Emperor Nicephoros Phocas with the latter identifying the Macedonian phalanx as his model. ${ }^{27}$ All the Taktika underline the importance of ambushes in war, with common stratagems being found in many of our works; indeed, the more popular ones are the placing of skirmishers at the end of a defile to block the march of an enemy force or to attack the enemy while returning home from foraging laden with supplies. ${ }^{28}$ Finally, it was deemed essential, according to recommendations of king Pyrrhus (paraphrased by Frontinus), "never to press relentlessly on the heels of an enemy in flight - not merely in order to prevent the enemy from resisting too furiously in consequence of necessity, but also to make him more inclined to withdraw another time". ${ }^{29}$

To conclude, what this paper has argued was that the knowledge of Antiquity in military matters was transmitted through the centuries to the Byzantines, whose strategic thinking was a conscious imitation of and adaptation to the ancient Greek military writings and recommendations of the Greek classical period, through the military treatises or Taktika that were compiled during the first and second centuries AD. The direction of my analysis was based on the definition of the term 
Taktika: as literary works of military nature compiled (a) through personal experience or (b) through oral tradition and other literary works of the past. Although the authors of the Taktika from the $4^{\text {th }}$ century AD to the Byzantine $10^{\text {th }}$ century were, in their majority, experienced officers in the field of war, I have argued that none of them were as great tacticians as the personalities whose exploits they examine in their works. Furthermore, this paper has shown significant links between (a) the written sources that our authors used to compile their works, especially for the Byzantine authors of Taktika in the $10^{\text {th }}$ century, and their access to their first century counterparts, and (b) the structure and contents of the Taktika through the centuries, from the notion of strategy and the way it was perceived to the different battle-formations and the employment of stratagems to defeat an enemy. Even though these manuals served to preserve the knowledge of the Ancient Greeks and the Romans in the Art of War, while at the same time offering a valuable source-book for the - mainly academic - education of contemporary Byzantine officers, these were not just copied texts taken from ancient authorities on the subject. The Byzantines revered the deep knowledge of the Greeks and the Romans in military matters, but the manuals compiled in the $6^{\text {th }}$ and 10 centuries AD were a conscious adaptation to the geopolitical realities of the present day with the authors willing to enrich the contents of their works rather than simply passing on obsolete battle-tactics. Indeed, through these manuals the Byzantines learned to understand war and its basic principles, like order, discipline and the creation of an adequate command structure - an invaluable lesson for every civilisation!

\section{REFERENCES}

1 Lilie, Ralph - Johannes, Die Byzantinische Realtion auf die Ausbreitung der Araber, Munich: Institut für Byzantinistik und Neugriechische Philologie der Universität München, 1976; Haldon, John F. and Kennedy, Hugh, “The Arab-Byzantine Frontier in the Eighth and Ninth Centuries", Zbornik Radova, Srpska Akademija Nauka i Umetnosti, Vizantoloski Institut, XIX, 1980, 79-116; Haldon, John F., Warfare, State and Society in the Byzantine World, 565-1204, London: UCL Press, 1999, pp. 34-46; Treadgold, Warren, "Byzantium, The Reluctant Warrior", in N. Christie, M. Yazigi (eds.), Noble Ideas and Bloody Realities, Leiden: Brill, 2006, 209-33; Kaegi, Walter E., "Some thoughts on Byzantine Military Strategy", The Hellenic Studies Lecture, Brookline MA: Hellenic College Press, 1983, 1-18.

2 It has been widely accepted that Aeneas Tacticus can be identified with Xenophon's Aeneas of Stymphalus in Arcadia, a general of the Arcadian League in 367 BC who drove out Euphron, the tyrant of Sicyon: Aeneas Tacticus, Asclepiodotus, Onasander, trans. by the members of the Illinois Club, London: Heinemann, 1923, p. 7 [from now on: Aeneas Tacticus, Asclepiodotus, Onasander]. 
3 The Emperor refers to the name of the author in the fourteenth constitution of his work (XIV. 112), something very rare considering the habit of ancient authors not to identify their sources. See also: Aeneas Tacticus, Asclepiodotus, Onasander, p. 352; McGeer, Eric, Sowing the Dragon's Teeth: Byzantine Warfare in the Tenth Century, Washington DC: Dumbarton Oaks, 1995, p. 189.

4 For example, regarding the events of the Athenian expedition to Sicily, the work provides us with information that cannot be found either in Xenophon or Thucydides' works:

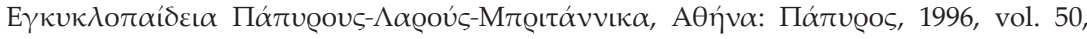
p. 104.

5 According to Theophylactos Simocattes, an early seventh-century Byzantine historiographer writing about the reign of Emperor Maurice (582-602): "A story was current that the general [Philippicos] who was very fond of learning and who drew his military knowledge from the experts of the past, had acquired this aptitude for wise strategy from the shrewdness of Scipio, the perfect general." The History of Theophylact Simocatta: An English Translation with Introduction, trans. by Michael and Mary Whitby, Oxford: Oxford University Press, 1986, I. 14. 2, p. 40.

6 Aeneas Tacticus, Asclepiodotus, Onasander, pp. 7, 10.

7 Lewis, Michael Jonathan Taunton, Millstone and Hammer: The Origins of Water Power, Hull: University of Hull Press, 1997, pp. 1-73 especially: pp. 44-45 and 58-60.

8 Aeneas Tacticus, Asclepiodotus, Onasander, p. 3.

9 The Tactics of Aelian, Comprising the Military System of the Graecians, London, 1814, I. 2.

10 Vegetius: Epitome of Military Science, trans. with introduction by N. P. Milner, Liverpool: Liverpool University Press, 2001, p. xxii.

11 Maurice's Strategikon: Handbook of Byzantine Military Strategy, English translation by George T. Dennis, Philadelphia: University of Pennsylvania Press, 1984 (latest edition: 2010), p. 8 [from now on: Strategikon].

12 The Taktika of Leo VI, text, translation and commentary by George T. Dennis, Washington DC: Dumbarton Oaks Texts 12, 2010, VII. 67. [from now on: Taktika]

13 Strategikon, p. 8.

14 Ibid., p. 8.

15 Vegetius, I. 8.

16 Sextus Julius Frontinus, The Stratagems and the Aqueducts of Rome, trans. by Bennett, Charles E., London: Heinemann, 1925, preface of book I, p. 3 [from now on: Frontinus]

17 Aeneas Tacticus, Asclepiodotus, Onasander, pp. 373-75.

18 Especially Frontinus' examples of Alexander the Great, Julius Caesar and the Byzantines with Philip the Macedon: Frontinus, III. 1-4, pp. 22-24; compare with: Aeneas Tacticus, Asclepiodotus, Onasander, XVI. 17-19, p. 86; Vegetius, III. 9; Strategikon, VII. 1-2.

19 Frontinus, I. i, 6, pp. 10-12; Vegetius, III. 26; Strategikon, VIII, 1. 8, 35; Taktika, XX. 8; Polyaenus, Stratagems of war translated from the original Greek, by Dr. Shepherd, F.R.S, London, 1796, 1. 14. 1 [From now on: Polyaenus].

20 Frontinus, I. ii, 1, 4, pp. 16-20; Polyaenus, 3. 39. 59; Strategikon, VIII, 1. 41; On Strategy, in George T. Dennis (trans.), Three Byzantine Military Treatises, Washington DC: Dumbarton Oaks, 2008, 39, pp. 116-18; Taktika, XX. 144.

21 Frontinus, I. v, pp. 34-52; Polyaenus, 2. 4. 2; Vegetius, III. 7, 22, pp. 78-79, 110; Strategikon, VIII/1. 19; On Strategy, ch. 19, pp. 62-68; The Anonymous Book on Tactics, in Three Byzantine Military Treatises, ch. 14, pp. 284-86.

22 Frontinus, I. v, pp. 34-52; Polyaenus, 1. 67, 2. 1. 8, 4. 2. 4; Strategikon, IX. 1.2; Taktika, XVII. 5.

23 Frontinus, I. iv, pp. 26-34; Polyaenus 2. 1. 30; Strategikon, IX. 4; Taktika, IX. 48.

24 Frontinus, I. xii, pp. 80-84; Polyaenus, 1. 32. 2, 2. 3. 3, 3. 10. 4; Taktika, XX. 78, 149, 156 where the latter copied: Polyaenus, 3. 10. 2. 
25 Frontinus, II. i, pp. 90-98; Aeneas Tacticus, Asclepiodotus, Onasander, XVI, p. 85; Vegetius, III. 10, 11, 22, pp. 88, 91, 109; Polyaenus, 8. 16. 1, 3. 9. 53, 8. 23. 4; Strategikon, VIII, 2. 40; IX, 1; Taktika, XVII.3, XX. 102-103.

26 Frontinus, II. ii, pp. 98-106; Aeneas Tacticus, Asclepiodotus, Onasander, XXI, pp. 451-59; Polyaenus, 1. 69. 3; Vegetius, III. 13, 20, pp. 92-93, 104; Strategikon, VIII, 2. 37; Taktika, XX. 96, 189; XIV. 77.

27 Frontinus, II, iii. 19, p. 118; Aeneas Tacticus, Asclepiodotus, Onasander, X, p. 411; Presentation and Composition on Warfare of the Emperor Nicephoros, in E. McGeer (trans. and ed.), Sowing the Dragon's Teeth: Byzantine Warfare in the Tenth Century, Washington DC: Dumbarton Oaks, 1995, I. 62-67, p. 16.

28 Frontinus, II. v, pp. 152-64 ; Aeneas Tacticus, Asclepiodotus, Onasander, XVI, p. 82; VII, pp. 403-5; X. 2, p. 415; Vegetius, III. 10, 11, pp. 88, 91; Strategikon, X. 2; On Skirmishing, chapts. 4, 9, 11, 23; Taktika, IX.25, 27-28; XVII. 37.

29 Frontinus, II. vi, 10, p. 169. See also: Aeneas Tacticus, Asclepiodotus, Onasander, XXXII, pp. 475-81; Polyaenus, 1. 30. 3, 2. 1. 6, 3. 9. 12/14, 8. 23. 29; Vegetius, III. 21, pp. 107-8; Strategikon, VIII.2, 92; IX.2; On Skirmishing, ch. 24, p. 234; Taktika, XVII. 19.

\section{BIBLIOGRAPHY}

\section{Primary sources}

Aeneas Tacticus, Asclepiodotus, Onasander. Trans. by the members of the Illinois Club. London : Heinemann, 1923.

Maurice's Strategikon: Handbook of Byzantine Military Strategy. English translation by George T. Dennis. Philadelphia : University of Pennsylvania Press, 1984 (latest edition: 2010). Polyaenus. Stratagems of war translated from the original Greek, by Dr. Shepherd, F.R.S. London, 1796.

Sextus Julius Frontinus. The Stratagems and the Aqueducts of Rome. Trans. by Bennett, Charles E. London : Heinemann, 1925.

The Tactics of Aelian, Comprising the Military System of the Graecians. London, 1814.

The Taktika of Leo VI. Text, translation and commentary by George T. Dennis. Washington DC : Dumbarton Oaks Texts 12, 2010.

Three Byzantine Military Treatises. Trans. by George T. Dennis. Washington DC : Dumbarton Oaks, 2008.

Vegetius: Epitome of Military Science. Trans. with introduction by N. P. Milner. Liverpool : Liverpool University Press, 2001.

\section{Secondary works}

Bachrach, Bernard S. The practical use of Vegetius' De re militari during the early Middle Ages. The Historian. XXXXVII, 1985, 239-55.

Dagron, Gilbert. Ceux d'en face: Les peuples étrangers dans les traités militaires byzantins. Travaux et Mémoires. X, 1987, 207-32.

Goffart, Walter. The Date and Purpose of Vegetius' De Rei Militari. Traditio. XXXIII, 1977, 65-100.

Haldon, John F. and Kennedy, Hugh. The Arab-Byzantine Frontier in the Eighth and Ninth Centuries. Zbornik Radova, Srpska Akademija Nauka i Umetnosti, Vizantoloski Institut. XIX, 1980, 79-116.

Haldon, John F. Warfare, State and Society in the Byzantine World, 565-1204. London : UCL Press, 1999, 34-46.

Kaegi, Walter E. Some thoughts on Byzantine Military Strategy. The Hellenic Studies Lecture. Brookline, MA : Hellenic College Press, 1983, 1-18. 
Lewis, Michael Jonathan Taunton. Millstone and Hammer: The Origins of Water Power. Hull : University of Hull Press, 1997.

Lilie, Ralph-Johannes. Die Byzantinische Realtion auf die Ausbreitung der Araber. Munich : Institut für Byzantinistik und Neugriechische Philologie der Universität München, 1976.

McGeer, Eric. Sowing the Dragon's Teeth: Byzantine Warfare in the Tenth Century. Washington DC : Dumbarton Oaks, 1995.

Shrader, C. R. The ownership and distribution of manuscripts of Flavius Vegetius Renatus' De re militari before the year 1300. PhD Thesis. University of Columbia, 1976.

Treadgold, Warren. Byzantium, The Reluctant Warrior. In: N. Christie, M. Yazigi (Eds.) Noble Ideas and Bloody Realities. Leiden : Brill, 2006, 209-33;

Wiita, John E. The Ethnika in Byzantine Military Treatises. PhD Thesis. University of Minnesota, 1977.

Georgijs Teotokis, Fatihas Universitāte, Turcija

NO SENĀS GRIEḲIJAS UZ BIZANTIJAS PASAULI: STRATĒG̣ISKS JAUNINĀJUMS VAI MILITĀRO ZINĀŠANU PĒCTECİBA?

Šā raksta mērḳis ir izvērtēt galveno jautājumu, ko uzdevuši izcili mūsdienu vēsturnieki par vairāku mūsu ēras pirmā un otrā gadsimta seno grieķu un romiešu Strategika vēsturisko vērtību. Tie ir literārie darbi, kas domāti armijas virsniekiem un kas satur konstitūcijas un militāra rakstura traktātus. Rakstā iztirzāts, kā šie darbi ietekmējuši militāro zināšanu nonākšanu no Senās Grieḳijas līdz Bizantijai un agrīnajai mūsdienu Eiropai. Tā kā šo militāro traktātu autori, piemēram, Onasandrs un Seksts Jūlijs Frontīns, nebija militārās jomas geēniji kā tie taktiḳi, kuru varoṇdarbus viṇi godā savos darbos, rakstā pierādīts, ka cauri gadsimtiem pastāv tieša sakarība starp minēto autoru pirmavotiem un Strategika struktūru un saturu, sākot ar viṇu izpratni par stratēgiju līdz dažādām kaujas viltībām un kaujas ierindām. Un, lai gan bizantieši bija mantojuši šîs lieliskās militārās zināšanas, izmantojot mūsu ēras pirmā un otrā gadsimta darbus, šajā pētijumā ir skaidri parādīts, ka viṇi nav vienkārši kopējuši senatnes autoritāšu tekstus par šo tēmu. Bizantiešu stratēǵiskā domāšana bija drīzāk apzināta seno dicta imitācija un pielāgošana esošajam impērijas ǵeopolitiskajam stāvoklim. 


\section{OJĀRS LĀMS}

Latvijas Universitāte, Latvija

\section{IZGLITTOTS PQMAIO (ROMEJS JEB BIZANTIETIS) UN} ANTĪKĀ LITERATŪRA.

Atsevišķa gadijuma izpēte: Leona Diakona teksti

\section{İss kopsavilkums}

Bizantijas tūkstošgadīgajā vēsturē nav iespējams runāt par vienotu un nemainīgu attieksmi pret izglītību. Atbilstoši valsts zaudējumiem un ieguvumiem dažādos laika posmos ir arī dažāda attieksme un prasības pret izglìtību. Liela nozīme saistībā ar valsts politisko iekārtu ir imperatora personīgajai attieksmei un ieinteresētībai. Tomēr, piedzīvojot gan uzplaukumu, gan panīkumu, viens no Bizantijas izglītības sistēmas stūrakmeņiem ir antīkā literatūra, un tās zināšanas ir izglītotības un kulturālības kritērijs. Par trim galvenajiem literārās gaumes un arī prasmju avotiem nosaucama historiogrāfija, rētorika un Homēra dzeja, liela nozīme ir arī antīko filozofu tekstu studijām. Tēlainības, alegoriskuma un simboliskas izteiksmes veidošanā arī kristīgie autori daudz mācās no antīkajiem autoriem, un, lai gan ik pa laikam saasinās radikālāko kristīgo aprindu negatīvā attieksme pret antīkajiem autoriem, tā nekad nekḷūst par dominējošu. Turpinās plaša antīkās literatūras recepcija, attiecībā uz autoru pagānismu paḷaujoties uz to, ka antīkie autori nav vainojami savos ticības maldos un ka Dieva žēlastība viņus paglābs no elles mokām, jo, patiesu Dievu nezinādami, viṇi tomēr ir dzīvojuši pēc Dieva likumiem.

X gadsimta autora Leona Diakons teksti Vēsture un Enkomijs ir saistošs piemērs tam, kā radoši tiek izmantots antīkās literatūras mantojums laikmetīgu un novatorisku tekstu sacerēšanā. Rakstīdams par sava laika aktualitātēm, Leons Diakons iedvesmojas gan no Homēra, gan sengrieḳu vēsturniekiem, gan grieḳu mitologijas.

Atslēgvārdi: izglītība Bizantijā, antīkā literatūra un Bizantija, X gadsimts, Leons Diakons.

Rietumu humanitārajā domā ir nostiprinājies jēdziens Bizantija šīs

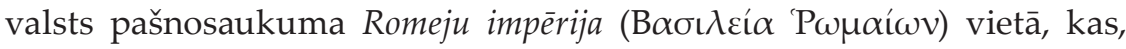
šķiet, ir ideoloǵisku motīvu izraudzīts ar nolūku distancēt Konstantinopoles pārvaldīto, reiz vareno un krāšņo valsti no Eiropas identitātei tik nozīmīgā antīkā kultūrmantojuma saglabāšanas. 18. un 19. gadsimtā ar nolūku vai nejauši tas ir kultivēts, vairojot šì jēdziena negatīvo nozīmju konotācijas lauku. Tā plaši pazīstams ir Voltēra izteiciens 
horrible et dégoûtant. Nosodoši izturoties pret Romas vēsturi impērijas laikā, pat tās turpinājumu Konstantinopolē, Voltērs rakstīja: Ir vēl viena vēsture, vēl vairāk smieklīga nekā Romas vēsture no Tacita laikiem. Šis necienīgais vākums sastāo no deklamācijas un brīnumiem; tas ir apkaunojums cilvēka prātam. Unisonā ar Voltēru izsakās Hēgelis, kurš apgalvo, ka valstij vienmēr draudēja briesmas, vispār tā ir pretīga vājuma aina, pie tam nožēlojamās un nejēedzīgās kaislības neḷāva parādìties lielām domām, veikumiem un personībām.

Edvards Gibons, kurš sarakstījis vienu no detalizētākajām un izvērstākajām Bizantijas vēsturēm, savam pētījumam devis nosaukumu Romas impērijas noriets un krišana, it kā visa tūkstošgadīgā Romeju impērijas vēsture būtu tikai sabrukuma stāsts.

Bizantija, būdama Romas turpinātāja, aiziet citu attīstības ceḷu nekā Rietumi, gadsimtu gaitā kḷūdama austrumnieciskāka un svešādāka, taču piedzīvo arī uzplaukuma periodus gan militāri, gan politiski, gan arī kultūrā un izglìtībā laikā, kad Rietumos valdỉja barbariska tumsa. 1000 gadu posmu raksturo gan kāpumi, gan kritumi, bet no 8. līdz 10. gadsimtam šī valsts piedzīvo spožu uzplaukumu arī intelektuāli un estētiski, tāpēc rietumnieku vispārinājumi nav îsti pamatoti. Protams, ir posmi Bizantijas vēsturē, kad tā ir militāri un ekonomiski novājināta un kad panīkst arī izglītības sistēma, taču zīmīgi, ka pēdējie gadsimti, kas patiešām jau ir valsts norieta gadsimti, iezīmējas ar kultūras un izglìtības uzplaukumu.

Bagātajā intelektuālajā dzīvē liela nozīme ir antīko tradīciju mantojumam un tālākattīstībai, daudzus tekstus saglabājot arī vēlākajai Rietumu renesansei. Ir taisnība, ka 529. gadā kristīgās motivācijas dēḷ tiek slēgta Platona akadēmija, zaudējums izglītībai un zinātnei bija arī Aleksandrijas iekarošana, ko paveica arābi. Tomēr jau 425. gadā imperators Teodosijs II nodibina Pandidakterionu - „visu macību skolu”, kas uzskatāma par augstākās izglītības iestādījumu, un dibināšanas notikums atspoguḷo valsts ieinteresētību izglītības pilnveidē un attīstībā. Privāta, uz antīkām tradīcijām balstīta izglītība pastāv arī līdz tam, bet ar šo lēmumu valsts uzn,emas atbildību un piešḳir finansējumu. Atbilstoši Bizantijas tradīcijām valsts finansētajai izglītībai ir augstāks prestižs, jo tā ir stabila, un tai arī tiek piešķirtas dažādas privilēgijas (valsts panīkuma posmos, protams, pagaist gan finansējuma stabilitāte, gan privilēǵijas). Pandidakterionu var uzskatīt arī par Rietumu universitāšu priekšteci. Kopumā tajā bija 31 pasniedzējs - pa desmit grieḳu un latīṇu valodai, divi tiesību jomā, viens filozofijā un astoṇi rētorikā jeb runas mākslā, no kuriem trīs strādāja grieḳu valodā un divi latīṇu valodā. 
Ir grūti spriest par šīs institūcijas funkcionēšanu, jo ziṇu ir maz, turklāt tā nebija stabila un pēc vairākiem gadsimtiem tā panīka, lai tiktu atjaunināta 11. gadsimtā. Taču no avotiem ir skaidrs, ka îpaša rosība izglītības jomā notiek 9.-10. gadsimtā, kas iezīmīgi ar antīko tekstu studēšanu un vākšanu. Kā divus izcilus piemērus var minēt Suidas leksikonu un patriarha Fotija bibliotēku, kas tika izveidoti laikā, kad Rietumos vēl nebija sacerēta pat Rolanda dziesma.

Valsts darbā humanitāra izglītība tika uzskatīta par absolūti nepieciešamu lietu. Bez tās nekāda virzī̌sanās pa karjeras kāpnēm nebija iedomājama, tāpēc varbūt arī Bizantijā nebija stabilas hierarhiskas skolu sistēmas un izglītošanās bija pašu interesentu rokās, jo ikviens, kas tiecās pakāpties pa sociālās hierarhijas kāpnēm (tas Bizantijā bija iespējams pretēji Rietumu feodālismam), pats par to arī rūpējās.

Kā jau minēts iepriekš, Bizantijas vēsture ir ḷoti garš laika posms, kura gaitā daudz kas mainījās, tāpēc nav iespējams runāt par vienotu attieksmi pret izglìtību. Valsts ieguvumi un zaudējumi, saskarsme ar citām kultūrām ietekmē visus sabiedrības pastāvēšanas līmeṇus. Bizantijā kā spēcīgi centralizētā un autokrātiskā valstī ḷoti liela un izšḳiroša nozīme bija valdnieka personībai, bet, tā kā varas mantošanas kārtība nebija likumā nostiprināta, jo valdīja uzskats, ka imperators ir dieva izredzēts, tad Bizantijas tronī sastopami gan augsti izglìtoti cilvēki, pat rakstnieki un vēsturnieki, gan arī zemnieki analfabēti. Bija imperatori, kas dāsni finansēja izglìtību, bet bija arī tādi, kas pilnībā to ignorēja. Valsts kases stāvoklis arī bija mainīgs un nepastāvīgs. Lai arī ir gadījumi, kad par Bizantijas imperatoriem kḷuvuši analfabēti (Justīns I un Bazils I), tomēr šḳiet, ka šì īpatnība viniiem jo spēcīgāk ḷāva saprast izglìtības nozīmi, un viṇu mantinieki, bērni un mazbērni pieder pie izglìtotākajiem un veiksmīgākajiem valdniekiem, piemēram, Justīna mantinieks Justiniāns - viens no spožākajiem visu laiku imperatoriem - vai arī Bazila I pirmā mazdēls Konstantīns VII Porfirogenēts, kurš ir izcils bizantiešu rakstnieks.

Neskatoties uz visiem kāpumiem un kritumiem valsts pastāvēšanas vēsturē, antīkais mantojums ir bizantiešu izglītības stūrakmens, kas organiski tiek papildināts ar baznīcas tēvu sacerējumiem, un šie baznīcas tēvi jau tāpat savas literārās prasmes apgūst no antīkās pasaules tekstiem. Seno tekstu zināšanas, prasmes tās lietot ir viens no galvenajiem izglītotas un kulturālas personības kritērijiem visas Bizantijas pastāvēšanas laikā. Varētu runāt par trim galvenajiem avotiem bizantieša literārās gaumes un literāro prasmju pastāvēšanā, un tie ir - Homēra 
dzeja, rētorika, historiogrāfija. Lai gan Bizantijā kopumā valdīja toleranta attieksme pret antīkajiem autoriem, ik pa laikam tomēr radikālākos baznīcas pārstāvjos uzliesmoja nepatika pret pagānisko mantojumu, tomēr šì pēctecības izjūta teksta veidošanas principos, estētisko un poētisko priekšstatu kopība nekad nelāva negatīvismam iegūt plašāku un vispārīgāku raksturu. Bizantiešu attieksmei drīzāk raksturīga spēja visu neiederīgo un no kristietības viedokḷa svešādo pārkodēt jaunā pieṇemamā zīmju sistēmā. Attiecībā uz pagānu autoriem, par kuru darbiem bizantieši turpināja jūsmot un mācīties no tiem, bija plaši izplatīts uzskats, ka dieva žēlastības neierobežotība šos pagāniskos autorus paglābs no elles mokām, jo viṇi dzìvojuši pēc dieva likumiem, dieva nezinādami.

Jau minēts, ka tieši 10. gadsimts būtu uzskatāms par vienu no tiem periodiem, kad izglìtībai tiek veltìta paša uzmanība, un šì laikmeta tekstos labi jūtama saikne ar antīko pasauli. 10. gadsimta autors Leons Diakons ( $\Lambda \dot{c} \omega v$ ó $\Delta \iota a ́$ Kovo / Leo Diaconus) ir spilgts sava laikmeta pārstāvis, un viṇa Vēsturē un Enkomijā, kas ir saturiski cieši saistīti ar sava laikmeta politiskajām aktualitātēm, vēstījuma tēlainībai un pasaules izjūtas atspoguḷošanai plaši izmantoti antìkās literatūras tēli, notikumi un stāsti.

Leons Diakons ir dzìvojis 10. gadsimtā imperatora Basila II laikmetā un atstājis unikālu materiālu - vēsturi par karagājieniem pret arābiem, bulgāriem un krieviem (959-976), kuros pats bijis līdzdalīgs. Šāds tiešs skatījums uz notikumiem ir diezgan reta parādība bizantiešu historiogrāfijā, jo lielākoties tomēr tiek vēstīts par notikumiem ar laika distanci. Taču izglītota romeja kontekstā pievērsīsimies nevis notikumiem, ko apraksta Leons, bet tam, kā viņš to dara. Par pašu autoru ziṇu ir diezgan maz, daḷēji tās smeltas no viṇa paša izklāsta. Zinātnieki ir centušies restaurēt gan viṇa dzīves gājumu, gan manuskriptu likteni, taču šāda rakstura minējumi nav šì raksta uzdevums. Īsi savelkot pretrunīgās ziṇas par Leona Diakona dzīvi, secināms, ka viṇš cēlies no diezgan turīgas, bet ne dižciltīgas ǵimenes Āzijā, izglītojies Konstantinopolē un pietuvinājies galmam un patriarham, un, visticamāk, patriarha dienestā

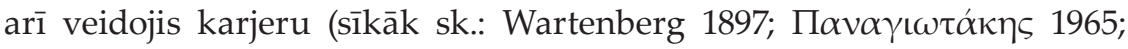
Сюзюмов 1988). Interesanti, ka arī tajās niecīgajā ziṇās, ko autors par sevi sniedzis Vēsturē, jūtama skološanās no Homēra, jo, raksturojot savu dzimto vietu, Leons Diakons min, ka tā atrodas Āzijā pie Kaīstras upes (Leo Diaconus, 1.1). Šāda norāde ir sasaukšanās ar Homēra Îliadas II dziedājumu, kurā kareivju pulki salīdzināti ar zosu bariem: .. Āzijas zālainās pḷavās pie Kaīstras plūstošās straumes .. (Īl., 2.461). Āzijas vārda lietošana arī 
ir antīks anahronisms, jo Bizantijā 10. gadsimtā tādu nosaukumu valsts teritorijas raksturošanai nelieto. Attiecībā uz savu gimeni Leons nosauc tikai tēva vārdu - Bazils (Leo Diaconus, 1.1), un tas liek domāt, ka Leons cēlies no sociāli necilas ǵimenes, jo Bizantijā nebija pieņemts nelietot titulus vai aizmirst par tituliem, ja tādi bija.

Leona Diakona izklāsta veidā ir skaidri jūtams, ka tekstu rakstījis kristīgs viduslaiku autors, tajā ir daudz atsauču gan uz Veco, gan Jauno Derību. Tajā pašā laikā skaidri jūtama ir arī antīkās literatūras tekstu klātbūtne. Homērs, senie vēsturnieki, senie mīti l̦auj reizumis skaidrāk, bet reizumis tieši aizplīvurotāk sniegt ieskatu un vērtējumu par vēroto un piedzivoto.

Jau pašā Leona Diakona vēstures sākumā sajūtama antīkās pasaules un tās izpratnes par vēsturi elpa - vēsture tiek raksturota kā dzīves skolotāja. Ja ir kāds labums, kas ir derīgs dzīvēe, tad lielākajā mērā tā ir vēsture, kas ir nepieciešama un derīga (1.1). Derīgums lielā mērā izriet jau no Polībija piedāvātās izpratnes par vēstures cikliskumu. Vēstures tēvs Hērodots tekstā ir minēts tiešā veidā, neprecīzi citējot (Leo Diaconus, 1.1), ka acīm jāuzticas vairāk nekā ausīm. Tukidīda un viṇa sekotāju mantojums redzams Leona paṇēmienā iekḷaut tekstā karavadoṇu izvērstas runas pirms izšķirošiem notikumiem. Nikifora runā autors piesauc romiešu senatnes slavu, tā ka te nav nekāda pārrāvuma, vienlaikus gan karš pret Krētu tiek tēlots svētā kara noskaṇās.

Vēstijumu kā būtisks Leona izteiksmes paṇēmiens caurauž Tihes pieminējums. Par Nikifora Fokas brāḷa Leona veiksmēm kara laukā autors saka: viṇu kaujas laukā pavadīja kāds dieviškss spēks (Leo Diaconus, 2.5), likteņa kaprīzes, labvēlība un nelabvēlība tekstā tiek pieminētas atkal un atkal. Tā bizantiešu domāšanai un rakstībai ir diezgan raksturīga izpausme, kad, nespējot notikumus iekḷaut skaidrā kristīgā redzējumā, viṇi tveras pie Tihes nepatstāvības. Antīkās mitoloǵijas motīvi autoram lauj netieši pateikt to, ko viņš vai nu reliğisku, vai politisku apsvērumu dēl negrib teikt tieši. Tā trešajā grāmatā par Nikifora gatavošanos karam Leons saka: Nikifors cerējis, ka Tihe uz vinu nebūs dusmīga, bet būs vēlīga un uzsmaidīs. Vesela trīsdalịga pasāža, kurā autors izvairās pieminēt paḷaušanos uz dievu, jo Nikifors bija lauzis zvērestu un tāpēc dieva aizgādniecība nebūtu vietā. Savukārt ceturtajā grāmatā, rakstot par Joanna Cimisha militārajiem panākumiem, autors viṇu salīdzina ar Homēra varoni Tīdeju (İl., IV, 373-400). Formāli Tīdejs piesaukts, lai raksturotu, ka neliela auguma vīrā var slēpties liela drosme, bet, tā kā 
mītiskais varonis nogalina savus brālēnus, tad viṇa pieminējums var norādīt arī uz līdzīgu finālu attiecībās starp Joannu un Nikiforu. Trešajā grāmatā gulošais Nikifors tiek salīdzināts ar Endimionu, kurš par sodu tam, ka nepiedienīgi uzlūkojis Hēru, tiek sodīts ar mūžīgu miegu. Iespējams, ka arī te ir kāda norāde uz notikumiem galmā.

Visbagātāk tekstā ir jūtamas vēsturnieku darbu studijas, ar tiem ienāk arī dažādi mītiski tēli, dažviet ir nelieli Romas dzejnieku citāti. Tomēr literāra mantojuma spēcīgākais akcents, kas liek sajust, ka autors stāv tajās pašās estētiskajās pozīcijās, kādās pasaule ir stāvējusi pirms viṇa, ir Homēra daiḷrades intensīvā klātbūtne darbā. Tā izpaužas salīdzinājumos, vietvārdu lietojumā, kas ir anahronisks geopolitiskajai realitātei, kā arī tiešos citātos. Tādējādi var secināt, ka Leona Diakona ḷoti konkrēti aprakstītie notikumi ir pasniegti veidā, kas ḷauj skaidri izlasìt un sajust autora plašo redzeslauku, literatūras zināšanas un estētisko gaumi.

$* * *$

Par antīkās lietartūras nozīmi bizantiešu sabiedrībā liecina kāds gadījums, par kuru pastāsta viens no izcilākajiem bizantiešu rakstniekiem, neilgi pēc Leona Diakona dzīvojušais Mihails Psells Hronogrāfijā. Paša Psella liktenis arī ir spilgts piemērs izglìtības nozīmei Bizantijas sabiedrībā. Psells dzimis trūcīgā gimenē, un jau agrā bērnībā vecāki bija izlēmuši viṇu skolot amatā, taču māte, pamanījusi dēla literārās spējas, pārliecināja tēvu atbalstīt dēla centienus. Savu karjeru Psells sāka kā rakstvedis. Slavinājumā Konstantīnam IX Monomaham Psells atspogulojis ne visai patīkamos rakstveža darba apstākḷus - garas darba stundas, aukstumu, gaisa trūkumu. Daudziem, kas cerēja uz izglītības pavērtām iespējām, tas arī palika augstākais sasniegums, kas radīja rūgtumu par dzīves neveiksmēm, tā teikt, - izglītība nepalīdzēja, tāpēc Bizantijas literatūrā atrodami arī kritiski izteikumi par izglītību, piemēram, 13. gadsimta filozofs Jozefs Rakendits, kas pats savulaik kājām bija devies no dzimtās Itakas uz Konstantinopoli, apgalvoja, ka vienkāršiem ḷaudīm tiekties pēc izglìtības ir ne tikai nevajadzīgi, bet pat kaitīgi, un ka tas ir tikpat kaitīgi kā stāvēt pārāk tuvu ugunij. Savukārt Mihails Apluhirs kādā retoriskā monologā liek savam varonim izteikties, ka bieži akmeṇkaḷi, kurpnieki un tirgoṇi, kas nespēj divus vārdus sakarīgi savienot, dzīvo labāk nekā skolots gudrinieks, jo prātu jau tirgū nepārdosi. Un galu galā arī šāda pretrunīga attieksme ir mantojums no antīkās pasaules, jo Aristotelis min Simonida izteikumu par bagātajiem un gudrajiem, ka 
labāk būt bagātam nekā gudram, jo viņš esot redzējis daudzus gudros pavadām laiku pie bagāto durvīm (Arist. Rhet., 2.16, 1391a). Aristotelis par sava laika bagātajiem saka: tie ir neaptēsti, bet par bizantiešu bagātniekiem to nevar teikt. Antīkās literatūras zināšanas, prasme tās lietot arī ikdienas sarunās ir identitātes kods, kas l̦auj sajust gadu tūkstošu klātbūtni.

Bizantijas sarežgìitajā un pretrunīgajā dzīvē antīkā literatūra savā ziṇā ir arī harmonizējošs un līdzsvarojošs spēks, un te jāatgriežas pie Psella rakstītā. Stāsts ir par notikumiem jau minētā Konstantīna IX Monomaha galmā. Imperators bija l,oti uzmīḷojis kādu dāmu, vārdā Marija Sklirena, un tas arī nav nekas neparasts imperatoru dzīvē, bet Konstantīns ir tik loti aizrāvies ar šo dāmu, ka ierāda tai apartamentus pilī un, noniecinādams stingro galma protokolu, parādās visur kopā ar viṇu un arī ar likumīgo sievu. Atmosfēra ir saspringta un neveikla, un te kādā galma sarīkojumā kāds galminieks ar nopūtu pasaka ov̉ vé $\mu \varepsilon \sigma \iota \varsigma[T \rho \tilde{\omega} \alpha \varsigma \kappa \alpha i$

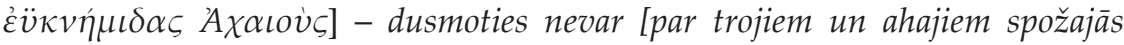
bruṇās ... (Īl., 3.156). Un sasprindzinājums izgaist - divi vārdi, bet visiem ir skaidrs, ka tie ir Homēra vārdi par Heleni, un sapratnes gars nolaižas pār publiku (Psellos, 6.61). Nepārsteigsimies, šo atsevišķo gadijumu vispārinot, saskatot antīkā mantojuma klātbūtnē kādu unikālu līdzekli, kas kliedē pretrunas un saasinājumus, bet vienu secinājumu var izdarīt, balstoties gan uz Leona Diakona tekstu, gan uz Mihaila Psella minētā piemēra izvērtējumu: antīkās literatūras mantojums ir būtiska izglītota romeja identitātes sastāvdaḷa.

\section{AVOTS}

Leo Diaconus. LEONIS DIACONI CALOËNSIS, HISTORIAE. E RECESIONE CAROLI BENEDICTI HASII. BONNAE, MDCCCXXVIIII. [cited 17. September 2013]. Available: http://books.google.lv/books?id=GCMAAAAAYAAJE pg=PA3Edq=\%22leonis+diaconi\%22Er edir_esc $=y \# v=$ onepage $\mathcal{E} q=\% 22$ leonis $\% 20$ diaconi $\% 22 \mathcal{E} f=$ false

\section{LITERATŪRA}

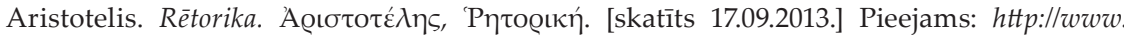
perseus.tufts.edu/hopper/text?doc=Perseus\%3atext\%3a1999.01.005

Gibbon, E. The Decline and Fall of the Roman Empire. Vol. 5. London, 1994.

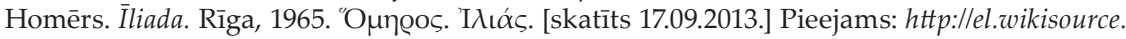
org/wiki/\%CE\%99\%CE\%BB\%CE\%B9\%CE\%AC\%CF\%82/\%CE\%93

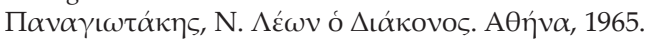

Psellus, M. Chronographia. [cited 17. September 2013]. Available: http://khazarzar.skeptik.net/ pgm/PG_Migne/Michael\%20Psellus_PG\%20122/Chronographia.pdf

Сюзюмов, М. Я. Дев Диакон и его время. Аев, Диакон. История. Москва, 1988. 
Arist. Rhet. - Aristoteḷa Rētorika

İl. - İliada

Ojārs Lāms, University of Latvia, Latvia

AN EDUCATED PSMAIO $\Sigma$ AND ANCIENT LITERATURE. A CASE STUDY: TEXTS BY LEO DIAKONOS

\section{Summary}

It is impossible to talk about an unified and constant attitude towards education in the thousand year long Byzantine history. There exists a varied attitude and different requirements in regard to education according to the losses and acquisitions of the state at different periods of time. A great role in the political system of the state is played by the personal attitude and interest of the emperor. Although there are periods of flourishing as well as decline, still one of the cornerstones of Byzantine educational system is ancient literature and its knowledge is a criterion for a educated and cultured person. The three main sources in the development of literary taste and skill are historiography, rhetoric and the poetry of Homer. In addition a great importance is attributed to the study of ancient philosophy. The Christian authors are learning a lot from the ancient ones in the creation of figures, allegories and symbols. Although time after time there is an exacerbation of negative attitude towards ancient writers among the radical minded Christian circles, this attitude never becomes predominant, as there is a widespread reception of ancient writers. What regards the pagan status of ancient writers, they are believed not to be blamed in their erroneous faith and that God's mercy will save them from the torments of hell, because they have lived by the laws of God, although unaware of Him.

The texts "Histories” and „Encomium” by the 10th century writer Leo Diakonus are an intriguing example of how the heritage of ancient literature is used in the creation of contemporary and innovative texts. In writing about the topics of his time Leo Diakonus got inspired by Homer, Ancient Greek historians and Ancient Greek mythology. 


\section{BRIGITA CĪRULE}

Latvijas Universitāte, Latvija

\section{AUGUSTĪNS EICĒDIJS UN VIṆA POĒMA DAUGAVAS PAKLĀJS: PAIDEIA DISKURSS}

\section{Īss kopsavilkums}

16. gadsimta Rīgas humānista Augustīna Eicēdija poēma Daugavas paklājs (Aulaeum Dunaidum), ja to skata paideia diskursā, skaidri manifestē ideju par paša dzejnieka un viṇa poēmā slavināto personu-Rīgas bīskapu un arhibīskapu - piederību vienai kultūrai, proti, izglītības/izglītošanās/izglītotības kultūrai, kas 15.-16. gadsimtā bija pārṇēmusi Rietumeiropu un gāja plašumā un kas bija sakṇota klasiskajā senatnē. Renesanses laikmetā Rietumeiropa pamazām atklāja antīkajā pasaulē izauklētās garīgās vērtības, kas l̦āva izveidoties izpratnei par humānistisku izglītības ideālu. Par pamatu ņemot seno romiešu autora Vergilija modeli, Eicēdijs poēmas 1335 heksametra rindās cildina izglìtotību un krietnos tikumus, ar kuriem apveltīti prominentie kristīgās baznīcas pārstāvji, kuri secīgi darbojas Livonijā, sākot no 12./13. gadsimta mijas līdz pat 16. gadsimta vidum.

Atslēgvārdi: Augustīns Eicēdijs, renesanse, humānistiskais izglītības ideāls, paideia diskurss, Vergilija modelis.

16. gadsimta Rīgas humānista Augustīna Eicēdija (Augustinus Eucaedius) poēma Daugavas paklājs, ja to skata paideia diskursā, skaidri manifestē ideju par paša dzejnieka un viņa poēmā cildināto personu piederību vienai kultūrai, proti, izglītības/izglītošanās/izglītotības kultūrai, kas ir sakṇota klasiskajā senatnē un kas 15.-16. gadsimtā bija pārnēemusi Rietumeiropu un gāja plašumā.

Seno grieḳu pasaulē paideia (izglītībalizglītošanās/izglītotība, audzināšana) pamatā ir ideāls, kas jāatdarina, ideāls, pēc kā jātiecas. Šis ideāls ir izglītots indivīds, kas iemieso sevī intelektuālo, morāli ētisko un estētisko kvalitāšu kopumu. Latīn,valodīgajā kultūrvidē jēdziena paideia ekvivalents ir humanitas, kas tiek aktualizēts renesanses laikā. Renesanses humānisms radās Itālijā 14. gadsimtā, un renesanse kā fenomens aptvēra visu Eiropu, iezīmējot pagrieziena punktu Rietumu vēsturē. Zināms, ka humānisma kustības pirmsākumos vairāk tika akcentētas antīko autoru darbu studijas. Parādījās izglītoti indivīdi, kuri intensīvi apguva 
antīko literatūru, iedziḷinājās atšḳirīgo literatūras žanru stila jautājumos, tiecoties atdarināt seno autoru māksliniecisko meistarību. Pamazām Rietumeiropa atklāja antīkajā pasaulē izauklētās garīgās vērtības, kuras ḷāva izveidoties izpratnei par humānistisku izglītības ideālu.

Laikam ritot, renesanses humānisms aizvien vairāk sāka ietvert sevī jau antīkajā pasaulē nostabilizējušos humanitas izpratni, kas apvieno tikumisku ideālu ar indivīda izglītotības ideālu. Humānisms, kā teicis Andris Rubenis (Rubenis 1995, 93), caurvij un balsta jebkuru no renesansē pārstāvētajiem mākslas virzieniem un sociālajām izpausmēm. Tas ir renesanses homo novus domāšanas veids, kas pasauli sāk griezt nevis ap teocentrisko, bet gan egocentrisko asi, pierādot cilvēka potences, kas bija brīvi izpaudušās Senajā Griekijāa un Romā. Nav šaubu, ka izglītība/izglītošanās/izglītotība ir viens no būtiskākajiem homo novus priekšnosacijumiem. Humānisti apgūst sengrieḳu un latīṇu valodu, studē klasisko mantojumu, tie veic izglìtības reformas un iezīmē pārmaiṇas kultūrā, kas 15. un 16. gs. izplatās visā Eiropā, lielā mērā pateicoties rakstniekiem un dzejniekiem. Pie šādiem dzejniekiem pieder arī Augustīns Eicēdijs, kurš acīmredzot ieguvis labu humānistisko izglītību vai nu Rīgas Domskolā, kurai bija liela nozīme vietējās intelektuālās elites veidošanā, vai kādā Eiropas augstskolā. Par pašu Eicēdiju biogrāfiskas ziņas nav saglabājušās, taču ir viṇa poēma Daugavas paklājs, kas skaidri manifestē dzejnieka piederību renesanses humānisma tradīcijai. Poēma sacerēta 16. gadsimta vidū un pirmo reizi izdota Vitenbergā 1564. gadā, bet atkārtotu izdevumu piedzīvoja 1794. gadā.

Augustīns Eicēdijs veltījis poēmu Sigismundam Augustam no Meklenburgas, kuram liktenis lēmis būt par arhibīskapu Livonijā. 16. gadsimts Livonijā ir nemierīgs laiks, pilns kara draudu un satraukumu; tas ir arī laiks, kad Lutera reformācijas vilnis sasniedz Livoniju, solot baznīcas atjaunotni. Augustīns Eicēdijs acīmredzot, atsaukdamies uz laikmeta notikumiem un jaunajām vēsmām no Rietumeiropas, sacerējis savu poēmu, kas pieskaitāma pie antīkajā pasaulē sakṇotā biogrāfiskā enkomija žanra.

Poēmas 1335 heksametra rindās ietverti biogrāfiski dati no virknes ievērojamu Rīgas bīskapu un arhibīskapu, kā arī citu nozīmīgu personu dzīves. Poēma izgaismo visai lielu periodu, sākot no 12./13. gadsimta mijas līdz pat 16. gadsimta vidum. Autors secīgi runā par prominentiem kristīgās baznīcas pārstāvjiem, kuri ieradušies ar misiju Livonijā un kuriem cauri gadsimtiem katram konkrētā periodā bijusi nozīmīga loma 

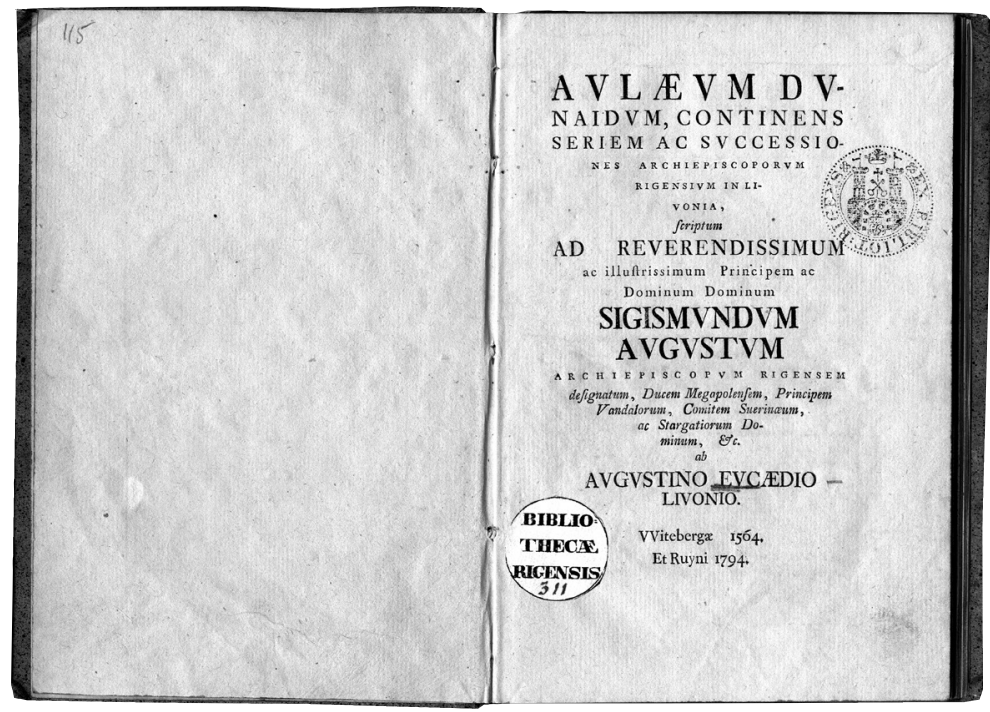

Poēma Daugavas paklājs sacerēta 16. gadsimta vidū un pirmo reizi izdota Vitenbergā 1564. gadā, bet atkārtotu izdevumu piedzīvoja 1794. gadā

kristietības izplatīšanā Livonijas teritorijā. Šie pārstāvji bijuši iesaistīti arī dažādos nemieros un tālab tiek apdziedāti poēmā un slavināti par cildenajiem darbiem, ko tie veikuši, un par krietnajiem tikumiem, ar kuriem bijuši apveltîti.

Cilvēkus un notikumus, par kuriem autors runā, poēmas nosaukums piesaista noteiktai teritorijai, proti, teritorijai pie Daugavas krastiem. Tas padara skaidru dzejnieka nolūku izmantot ūdens nimfas najādas kā palīdzes, kuru uzdevums ir aust paklāju. Nimfas tiek ievietotas lokālā kontekstā - viṇas mājo Rūbonas/Dunas jeb Daugavas ūdeṇos. Šo mitologisko tēlu izvēle ir nozīmīga poēmas kompozīcijai. Poēmā viṇas tiek sauktas par nimfām audējām (nymphae textrices). Dzejnieks padara nimfas par aculieciniecēm notikumiem, kas norisinājušies Daugavas krastos gadsimtu gaitā, viṇu uzdevums ir paturēt atmiṇā cilvēkus un viṇu veiktos varoṇdarbus, un tieši viņas ir tās, kuras secīgi ieauž paklājā poēmas varoṇus - Rīgas bīskapus un arhibīskapus, tādā veidā nodrošinot viṇiem mūžīgu slavu. Dzejnieka izvēle izmantot prominentus kristīgās baznīcas pārstāvjus par poēmas varoṇiem apliecina autora nodomu slavināt arī pašu kristīgo baznīcu, tās ideoloǵiju, vēršot uzmanību uz baznīcas atjaunotni. Taču svinīgais patoss, ar kādu tiek cildināti gan paši bīskapi, 
gan viṇu veikums, liek domāt, ka autoru tikpat labi varēja būt vadījusi dzejniekiem humānistiem raksturīgā vēlme izcelt tikumu, mudināt lasītāju uz tikumisku rīcību, kas vienlaikus nozīmē mudināt arì tiekties pēc izglìtības.

Aplūkojot poēmu paideia diskursā, svarīgi pievērst uzmanību seno romiešu autora Vergilija (Publius Vergilius Maro, 70-19) modelim, kas neapšaubāmi ir poēmas pamatā. 16. gadsimtā Rietumeiropas renesanses humānistiem bija īpaša interese par dzejnieku Vergiliju, kuru šajā laikā uzskatīja par visizcilāko latīṇu autoru, un šì interese ienāca arī Baltijas reǵionā. Vergilijs bija dzejnieks, kas renesanses laika izglītībā, kultūrā, renesanses laika domā ien,ēma īpaši nozīmīgu vietu. Kā atzīst zinātnieks Džefrijs Glodziks, renesanses humānistu intelektuālā programma uzskatīja antīkos autorus par galveno cilvēka gudrības un tikumisko vērtību avotu (Glodzik 2009, vi).

Nav šaubu, ka Augustīns Eicēdijs pakārtojis Eneidas modeli saviem poētiskajiem un ideoloǵiskajiem mērķiem. Jau pati Vergilija iecere ar savu eposu cildināt Romas pirmā imperatora Oktaviāna Augusta nākšanu pie varas un viṇa valdīšanu kalpojusi kā iedvesmas avots Augustīnam Eicēdijam. Vergilijs veiksmīgi izvēlējies mītu par varoni Aineju, lai parādītu, ka romieši ir tie, kuri spējīgi veikt lielus varoṇdarbus un nozīmīgas lietas. Galvenais varonis Ainejs Vergilijam ir gudrs vīrs, iesaistīts militārās aktivitātēs, viņš attēlots kā varonis glābējs, viṇšs vēlas atbrīvot pasauli no l,aunuma, viņam ir noteikta misija. Vergilijs akcentē Aineja misiju darboties pilsoṇu kopienas labā: viņš ir tas, kuram jāuzveic ḷaunie spēki. Viṇa personiskā griba ir pakḷauta liktenim.

Romā Oktaviāns Augusts ar relatīvo mieru, ko viņš atnesa romiešiem pēc postošajiem pilsoṇu kariem 1. gadsimtā p. m. è., un dievbij̄̄gais Ainejs-pius Aeneas, kas iemieso sevī romiešu ethos, lieliski kalpo Eicēdija nodomam slavināt Sigismundu Augustu kā potenciālo arhibīskapu Livonijā 16. gadsimtā, kā arī cildināt slavenos Rīgas bīskapus un arhibīskapus, kuri cauri laikmetiem ar misiju bija ieradušies Livonijā un aktīvi darbojušies sabiedrības labā. Nymphae textrices viṇus vienu pēc otra ieauž paklājā, stāstot par viṇu cīnāam pret zemes ienaidniekiem:

\section{Uzsprauž tās steidzīgi sniegbaltos tērpus un kailajām rokām}

Šķetina ārā no klūdziņu groziem jau dzīparus smalkos,

Audumā vieno, ar atspoli klejojot veikli pa metiem,

Attēlo tēvus ar priesteru saiti no sākotnes senās.

(Eic. Daug., 120-123; R. Šestaka atdz.) 
Bet pāri visam redzama autora vēlme parādīt baznīcas prominentās figūras kā tādas, kas pūlas vietējo iedzīvotāju labā; kā tādas, kam ir mērķis vietējos, kuri aizvien grib pielūgt savus pagāndievus, vadīt uz civilizētāku, izglītotāku sabiedrību un ieviest jaunu kārtību. Dzejniekiem humānistiem ir raksturīgi akcentēt saikni, kāda pastāv starp valdnieku/ vadītāju aktivitātēm un viņu izglītotību, jo šādā veidā ir iespējams skaidrāk parādīt piederību kopējai izglītības/izglītošanās/izglītotības kultūrai.

Vergilija modelis pirmām kārtām saskatāms pašā Eneidas idejā, proti, atbalstìt valdnieku un viņa aktivitātes. Kad Eicēdijs runā par Sigismunda Augusta ierašanos Livonijā, viņš izmanto Vergilija stilam raksturīgo valodu, kas atbalso t. s. Augusta mieru (Pax Augusta), ar kuru caurstrāvota Eneida. Vergilija poētiskās formulas poēmā marḳē alūziju uz Vergilija eposa tekstu. Poēmas sākumā Augustīns Eicēdijs, sekojot antīkajai tradīcijai, aicina mūzas un jauno valdnieku palīdzēt viṇam poētiskajos centienos:

Teiciet man, dievišǩ̄s Pièra meitas, šo prieku, kas radies

Sarmatu ciltij, ko apskalo Rūbonas tecējums mūžžigs,

Izklāstiet, mūzas, nu kopāa ar mani tik lielajai lïksmei

Zìmīgos iemeslus! Labvè̄līgs arì tu, slaveno kẹnin

August, šai veicamā darbā un pūlēs mums palīgā steidzies ..

(Eic. Daug., 1-5; R. Šestaka atdz.)

Citāta pēdējā rinda latīniskā variantā - Auguste, huic nostro praesens succurre labori, - atsauc atkal atmiņā Vergilija Eneidu: Tu, dea, tu praesens, nostro succurre labori (Verg. Aen., 9.404). Vergilijs nereti izmanto darbības vārdu succurrere (steigties palīgā), kad kādam varonim nepieciešams vērsties pēc palīdzības pie dieviem, bet Eicēdijs vēršas pie valdnieka un lūdz palīdzību, vienlaikus sveicot jauno valdnieku, kurš livoniešiem nesīs mieru, jaunu laikmetu un lietu kārtību. Vergilija poētiskā formula nostro succurre labori zināmā mērā atbalso Romas pirmā imperatora Oktaviāna Augusta pretenzijas uz dievišķu izcelsmi un, pateicoties asociācijai, lasītājam liek domāt par atnākušo valdnieku, kurš tiek cildināts kā dievs.

Augustīns Eicēdijs ar savu poēmu sveic Sigismunda Augusta valdīšanu un liek cerēt uz mūžīgu mieru Livonijā - gluži kā mieru, ko iedibināja Oktaviāns Augusts Romā priekš romiešiem. Pats liktenis lēmis viņam būt valdniekam Livonijā un būt par Kristus priesteri (sacerdos Christi): 
Pieprasa likteṇi lemtie, lai tavējiem l̦audìm par kungu,

Pravieti diženu Sigismunds Augusts reiz nāktu, no senas

Ķēniņu dzimtas kas cèlies, ar dedzību, garu un runu

Slavens kas plaši. Jau līksmē šalc tālākie Baltijas krasti!

Būs tas gan stūrmanis tautai, gan priesteris svētais iekš Kristus.

(Eic. Daug., 64-68; R. Šestaka atdz.)

Ar alūziju uz Oktaviāna pax Augusta Eicēdijs piešķir autoritāti un cieṇu Sigismundam Augustam, kā arī pašai kristīgajai ticībai. Projicējot Vergilija tēlus Livonijas vidē, Eicēdijs slavina jauno valdnieku un sekmē tā godāšanu. Sigismunds Augusts tiek parādīts kā ar gudrību apveltīts augstas morāles un krietnu tikumu vīrs. Latīnu vārds virtus (krietnums) dominē rindās, kurās slavināta valdnieka atnākšana. Šeit svarīgi pievērst uzmanību alūzijai uz mitoloǵisko zelta laikmetu, ko nereti izmanto antīkie dzejnieki savā dzejā: iam redit et virtus, redeunt nunc aurea rursus saecula. (Euc. Aul., 80) - jau atgriežas tikums no jauna un zeltlaiki gaišie (R. Šestaka atdz.) // iam redit et virgo, redeunt Saturnia regna (Verg. Ecl., 4.6.) - jau atgriežas arī jaunava, jau atgriežas Saturna valstība (B. Cīrules tulk.).

Ir skaidrs, ka Sigismunda Augusta atnākšana tiek saistīta ar zelta laikmeta atgriešanos, kas asociējas ar mieru un krietniem tikumiem. Alūzija uz zelta laikmetu, kas atgriežas, ir pietiekami ekspresīva: tā vedina domāt par mieru un zināmu pārpilnību, kā arī par atgriešanos pie pilsoṇu karu laikā Romā aizmirstajiem dievu kultiem, kurus atjaunoja Oktaviāns Augusts 1. gs. p. m. è. Tāpat šì alūzija var likt domāt par seno mitologíisko pagātni, kurā valda miers, harmonija, pašas dabas dotā pārticība un tikums. Augustīns Eicēdijs slavina zelta laiku atgriešanos Sigismunda Augusta vadībā. Jāpievērš uzmanība verbam redire (atgriezties). Pētnieks Džefrijs Glodziks (Glodzik 2009, vii), analizējot neolatīṇu dzeju Romā, atzinis, ka Vergilija tèmas un epizodes renesanses neolatīnu dzejā parasti ietver domu par atjaunotni, kas atbilst pāvesta ideologijas raksturam 16. gadsimtā. Nav šaubu, ka šāda doma par atjaunotni/atjaunošanos saskatāma ar̄i Eicēdija dzejā. Un, ja ņemam vērā, ka renesanses laikā Vergilijs nereti tika lasīts caur kristietības prizmu, tad varētu būt gluži vilinoši interpretēt Eicēdija pieminēto zelta laikmetu kā kristiešu jauno laikmetu, kas atnācis, pateicoties reformācijai. Poēmas Daugavas paklājs lasītājs tiek aicināts domāt, ka Livonija katrā ziṇā baudīs prieku par mieru un jauno laikmetu, kas piepildīts ar krietniem tikumiem Sigismunda Augusta vadībā. 
Vergilija modelis saskatāms arī poēmas varoṇu - Rīgas bīskapu un arhib̄̄skapu - atainošanā. Kristīgās baznīcas pārstāvju atspoguḷojums raisa asociācijas ar Vergilija episkās poēmas galveno varoni Aineju. Bīskapu slavināšanai ir veltīta lielākā daḷa Eicēdija poēmas vārsmu. Dzejnieks cildina slavenos darbus, ko paveikuši tādi bīskapi kā Meinards, Bertolds, Alberts un daudzi citi, kas pagātnē ieradušies Livonijā un kḷuvuši slaveni, pateicoties militārām aktivitātēm, kā arī atjaunojot ēkas, kas nopostìtas karos, un ceḷot jaunas ēkas. Te atkal prātā nāk Oktaviāna Augusta aktivitātes Senajā Romā - pateicoties tām, daudzi pilsoṇu karos nopostītie dievu tempḷi un altāri tika atjaunoti. Seno dievu kultu un tempḷu atjaunošana tika uzskatīta par dievbijības (pietas) izrādī̌̌anu. Pietas romiešu pasaulē ir augstākā tikumiskā vērtība. Tā ietver bijīgu attieksmi pret savu ǵimeni un dzimtu, bij̄̄gu attieksmi pret tēviju un bijīgu attieksmi pret dieviem. Ainejs, Vergilija eposa Eneida varonis ir šīs tikumiskās vērtības iemiesojums.

Aineja darbošanās kalpo kā tikumiskās uzvedības paraugs renesanses laika dzejniekam Augustīnam Eicēdijam. Trojiešu varonis seko dievišķajam lēmumam, demonstrējot savu pietas. Lìdzīgā veidā baznīcas pārstāvji darbojas kā Livonijas glābēji. Eicēdijs, škiet, ir uztvēris Vergilija eposa reliğisko dimensiju, kas manifestējas galvenā varoṇa tēlā, kurš izceḷas ar savu pietas. Arī Eicēdijs, runājot par bīskapiem, tekstuāli liek uzsvaru uz leksēmu pietas, asociējot savus varoṇus ar noteiktām ètiskām un sociālām vērtībām. Viṇi tiek atainoti kā morāles ziṇā perfekti, kā apveltīti ar katru tikumu. Tādējādi Eicēdija poēma var tikt uzskatīta par ideālu nesēju. Un tā ir klasiskajā senatnē balstītā latīṇu valoda, kas kalpojusi dzejniekam kā instruments, kas palīdzējis viņam izteikt jaunā laikmeta idejas, pieredzi un mākslinieciskos centienus, jo tā piedāvā plašas stilistiskās un leksiskās iespējas, kā ar̄ paraugus (exempla), lai atspoguḷotu šo jauno 16. gadsimta laikmetu, kas tiecas uz izglītības/ izglītošanās/izglītotības kultūru.

Pietas ir to dzejnieka humānista tikumu vidū, kas pirmām kārtām tiek asociēti ar izglìtotību, ar gudrību. Tāpēc atainoto bīskapu gudrība aizvien tiek cildināta viṇu aktivitātēs. Bīskapu slavināšanā autors izmanto antīkajā rētorikā smeltās tradicionālās slavināšanas formulas ar nolūku izraisīt viṇu apbrīnu. Un nav šaubu, ka autors veidojis varoṇus atbilstošus sev nozīmīgām vērtībām. Visi bīskapi tiek cildināti kā modeḷi krietnai uzvedībai un gudrībai. Piemēram, pirmais Livonijas bīskaps Meinards tiek raksturots kā izglītots (doctus), bet bīskaps Bertolds 
raksturots kā vīrs ar saprātīgu domu (sapiens), savukārt Alberts - kā gudrs (prudens).

Bīskapi ir apveltīti ar gudrību un ikkatru tikumu, taču vietējie iedzīvotāji, šķiet, nav bijuši apveltīti ar gudrību un slavējamiem tikumiem. Poēmā vērojami centieni noniecināt vietējos iedzìvotājus. Jādomā, ka to vairāk diktējusi autora tieksme skaidrāk izcelt jaunā laikmeta vērtības, nevis vēsturiskās patiesības meklējumi.

Tikums un izglītotība ir cieši saistīti, jo rakstura veidošana ir galvenais mērḳis humānisma laika izglītības programmā. Izglìtībai nav vērtības, ja tā neiespaido uzvedību. Poēmā lielāko daḷu bīskapu biogrāfiju aizṇem militāru aktivitāšu atspoguḷojums, jo tas ir labākais veids, kā slavināt personu un parādīt tās tikumus. Dzejnieks bīskapus raksturo ar tādiem epitetiem kā dievbijīgi, žēlsirdīgi un uzticīgi.

Bet viscaur poēmai Daugavas paklājs lasītājs nevar nepamanīt mērḳi, kura dēl nopūlas un lej asinis kristīgās baznīcas prominentās figūras. Bīskapi aizsargā cilvēkus kara laikā, un viṇiem jārūpējas par cilvēkiem miera laikā. Nest mieru, taisnīgumu un kristiešu vēsti Livonijas iedz̄̄votājiem ir galvenais mērḳis, taču Eicēdija poēma parāda arī to, ka jauns laikmets atnācis Livonijā, un šì laikmeta raksturiezīme ir paideia. Eicēdijs interpretē Vergilija cildināto Oktaviāna Augusta laikmetu Livonijas kontekstā - kā jauna izglītotības laikmeta atnākšanu šajā Baltijas jūras krastā.

Zināšanas antīkajā rētorikā l̦āva dzejniekam būt daiḷrunīgam, gan slavējot jauno baznīcas valdnieku un bijušos līderus par vin̨u varoṇdarbiem un godājamiem tikumiem, gan nopeḷot vietējos iedzìvotājus par to, ka tie aizvien grib pielūgt savus pagāndievus, gan nosodot iebrucējus, kuri Livonijai nesuši kara šausmas un postu. Dzejnieka spēja būt daiḷrunīgam neapšaubāmi sakṇojas labā izglītībā - izglītībā, kas iegūta, studējot klasisko senatni ar tās bagāto mītu klāstu, ar filozofisko domu, ar rētoriku, kas nodrošina runas prasmi, ar daudzveidīgo literatūru, kas iedvesmo.

\section{BIBLIOGRĀFIJA}

Aulaeum Dunaidum, continens seriem ac successiones archiepiscoporum Rigensium in Livonia, scriptum ad Reverendissimum ac Illustrissimum Principem ac Dominum Sigismundum Augustum Archiepiscopum Rigensem designatum, Ducem Megapolensem, Principem Vandalorum, Comitem Suerinaeum ac Stargatiorum Dominum, etc. ab Augustino Eucaedio Livonio. Witebergae 1564 et Ruyni 1794. 
Glodzik, Jeffrey. Vergil and Vergilianism in High Renaissance Rome. Ph. Dissertation. State University of New York at Buffalo, 2009.

Rubenis, Andris. Dzīve un kultūra Eiropā renesanses un reformācijas laikmetā. Rīga : Zvaigzne ABC, 1995.

Brigita Cīrule, University of Latvia, Latvia

AUGUSTINUS EUCEDIUS AND HIS POEM

THE DAUGAVA CARPET: PAIDEIA DISCOURSE

Riga's $16^{\text {th }}$ century humanist Augustinus Eucedius's poem The Daugava Carpet (Aulaeum Dunaidum), when viewed in the paideia discourse, clearly manifests the idea that the poet and the persons glorified in his poem - bishops and archbishops of Riga - belong to the same culture, that is, the culture of education/learning/literacy that was spreading and overwhelmed Western Europe in the $15^{\text {th }}-16^{\text {th }}$ centuries and was rooted in classical antiquity. During the Renaissance Era, Western Europe gradually discovered the spiritual values that had been nurtured in the Classical Antiquity, which led to the formation of a humanistic educational ideal.

The 1335 hexameter lines of Eucedius's poem celebrate prominent representatives of the Christian Church who came with a mission to Christianize the local population in Livonia from the turn of the $13^{\text {th }}$ century to the mid-16 ${ }^{\text {th }}$ century. Basing his poem on the ancient Roman poet Virgil's model, Eucedius not only glorifies Archbishop Sigismund Augustus and the bishops for the benefit of Livonia's citizens but also praises their literacy and upright morals. 


\title{
DACE STRELĒVICA-OŠIN̦A
}

Latvijas Universitātes Latviešu valodas institūts, Latvija

\author{
CUSTOS SERMONIS (VALODAS SARGS): \\ İSS IESKATS IZPRATNĒ PAR DZIMTĀS VALODAS \\ MĀCǏŠANU LATİNU UN LATVIEŠU TRADĪCIJ Ā
}

\section{İss kopsavilkums}

Rakstā aplūkots daudzās lingvistiskās kopienās novērojamais preskriptīvisms - tāda attieksme pret valodu, kas atbalsta stingru sekošanu normām, cerot saglabāt valodas pareizību un tīrību. Balstoties uz maniem iepriekšèjiem pētījumiem, šai darbā sniegts ieskats trīs preskriptīvisma virzienu teorijā un īpaši izcelti daži aspekti, kas saistās ar izglītības un pedagoǵijas jomu. Dzimtās valodas un gramatikas skolotājs kā valodas sargs un cilvēka identitātes veidotājs - šāds uzskats nav bijis svešs nedz Senajā Romā, nedz Latvijā dažādos laikmetos.

Atslēgvārdi: valoda, izglītība, preskriptīvisms, pūrisms, pareizība.

\section{KAS IR VALODAS SARGS?}

Virsrakstā minētais apzīmējums custos sermonis (valodas sargs) ir romiešu autora Senekas (Lucius Annaeus Seneca, 4. g. p. m. è.- m. è. 65. g.) savulaik kādā vēstulē (Epistula, 95.65) lietota un vēlāk dažādos avotos citēta frāze. Vēlākos laikos Augustīns (Augustinus Hipponensis, 354.-430. g.) kādā no saviem darbiem ir lietojis jēdzienu custos historiae (vēstures resp. tradīijas sargs), aprakstot teorētisku situāciju, kad par nepareizu patskan,a izrunu dzejas valodā pārmetīs gramatiķis - viņ̌s, protams, ir tradicijas sargs (reprehendet grammaticus, custos ille videlicet historiae) (De musica, 2.1.1).

Amerikāṇu klasiskais filologs Roberts Kasters (Robert A. Kaster), kas antīko laiku gramatiķiem (t. i., gramatikas pratējiem un skolotājiem) veltījis apjomīgu pētìjumu, Senekas frāzes custos sermonis anglisko tulkojumu guardian of language ne bez iemesla iekḷāvis savas grāmatas virsrakstā un atsaucas arī uz Augustīna lietoto apzīmējumu, kas vēl vairāk paplašina gramatiḳa tradicionālās lomas uztveri romiešu sabiedrībā. Kā jau 
valodas un tradīcijas sargs, gramatikikis lìdzinājās tiem, kas sargāja robežu starp kārtību un haosu, raksta R. Kasters. Līdzīgi armijas virsniekam Romas impērijas robežteritorijā vai arī provinces pārvaldniekam, kas pilda tiesneša pienākumus, gramatikis savā jomā bija tikpat svarīgs, stāvēdams lingvistisko, ǵeogrāfisko un sociālo atšķirību robežpunktā. (..) Valodiskās sardzes pienākumi (linguistic guardmanship) [bija] gramatiķa profesijas svarīgākā un sarežógit ākā daḷa (Kaster [1988] 1997, 18).

Raksturojot tās profesijas, kuru pārstāvjus sabiedrība objektīvi vai subjektīvi uzskata par atbildīgiem valodas jautājumos, savulaik esmu lietojusi metaforisku apzīmējumu „valodas pareizības misionāri”. Pie šīm profesijām pieder valodnieki, pedagogi, grāmatizdevēji, literāti, žurnālisti u. c. (Strelēvica-Ošiņa [2011] 2012, 116-158). Pirmie divi šai uzskaitījumā, iespējams, ir visbūtiskākie - gan sabiedrības priekšstatos, gan arī realitātē. Turklāt senatnē, kā škiet, robeža starp šīm abām profesijām - vienu, kas pēta valodas jautājumus, un otru, kas tos māca citiem, - nebija tik stingri novilkta.

Par gramatiķa nozīmīgumu antīkajā sabiedrībā ir daudz liecību. Piemēram, Malkolms Haimans (Malcolm D. Hyman) kādā pētījumā uzsver to, ka klasiskās latīnu valodas periodā seno romiešu gramatiḳi reizēm bija ne tikai valodas, bet arī religijas eksperti; valodas pareizībai (it īpaši religískos tekstos un ceremonijās) bija īpaša simboliska nozīme (Hyman 2002). Savukārt romiešu autora Svetonija (Gaius Suetonius Tranquillus, 69. g. - ap 122. g.) darbā De Grammaticis ir aprakstìta epizode, kur kāds gramatiḳis kritizējis imperatora Tibērija lietotu nepareizu vārdu, teikdams: Tu, valdniek, vari dot pilsonību cilvēkiem, bet ne vārdiem (Tu enim, Caesar, civitatem dare potes hominibus, verbo non potes) (De grammaticis, 22).

Protams, tas nenozīmē, ka latīniski runājošajā sabiedrībā gramatiķus vienmēr vērtēja pozitīvi. Kā norāda R. Kasters (Kaster [1988] 1997, 50-60), romiešu rakstnieka Aula Gellija (Aulus Gellius, ap 125.-180. g.) grāmatā Noctes Atticae aprakstīto gramatiḳu lielākā daḷa parādīti kā komiski tēli tādi, kas agresīvi strīdas par nenozīmīgām valodas detaḷām, neizceḷas ar augstu morāli utt. Taču, kā secina R. Kasters, tas nenozīmē, ka Aulam Gellijam gramatika un gramatiķi liktos nebūtiski - gluži otrādi, viņiem pievērstā uzmanība liecina, ka šì joma šḳitusi pietiekami svarīga. Turklāt minētā romiešu autora izteiksmes veids un spriedumi rāda, ka viņš savā laikā saṇēmis labu izglītību gramatikas jomā, turklāt viṇš kā pozitīvu piemēru aprakstījis intelektuālo, aristokrātisko gramatiḳi Sulpīciju 
Apolināriju (Sulpicius Apollinaris, m. è. 2. gs.), kas savā laikā bija mācījis Aulu Gelliju pašu (Kaster [1988] 1997, 50-60).

\section{TRĪS IEMESLI, KĀPĒC TIEK SARGĀTA VALODA}

Kāds iemesls bija tam, ka tik svarīgu lomu ieguva cilvēki, kuru profesija un aicinājums bija valoda un gramatika jeb recte loquendi scientia (pareizas runāšanas māksla), kā to savā slavenajā grāmatā Institutio Oratoria definējis Kvintiliāns (Marcus Fabius Quintilianus, 35.-100. g.)? Turklāt vai gan priekšstats par valodnieku un valodas skolotāju kā „pareizās” valodas sargu būtu vienīgi antīkās kultūras mantojums?... Protams, nav šaubu, ka romiešu preskriptīvisma tradīcija ir atstājusi iespaidu uz Rietumu kultūrtelpas lingvistiskajām attieksmēm daudzu gadsimtu garumā - gan tiešas, gan netiešas ietekmes un aizgūšanas cel̦ā. Tomēr nenoliedzami ir tas (ko apliecina dažādi pētnieki), ka tieksme pēc valodas pareizības - tāpat kā tieksme pēc zināmu tradīciju un kārtības ievērošanas vispār - ir cilvēka dabā, un tās iemesli var būt tiklab psihologiski, kā arī vēsturiski, sociāli utt.

Pilnīgi visus iemeslus tam, kādēḷ dažādu kultūru un laikmetu cilvēki vēlējušies saviem bērniem mācīt „pareizo” valodu, t. i., kādēḷ vispār pastāv preskriptīvisms un rūpes par valodas pareizību, laikam gan nebūtu iespējams aptvert. Taču var izšķirt apmēram trīs galvenos šīs parādības virzītājspēkus jeb, precīzāk sakot, trīs galvenos preskriptīvisma veidus, kas raksturīgi zināmiem sabiedriskiem vai psiholoǵiskiem apstākḷiem. Tādēl esmu savulaik (Strelēvica-Ošiņa [2011] 2012, sk. arī 2010) piedāvājusi šādu klasifikāciju:

1) uz cilvēku orientētais preskriptīvisms - angḷu valodas vidē pazīstamais (senāk plaukstošais, pēdējā gadsimta laikā bieži kritizētais) preskriptīvisma virziens, kur cilvēka lietotās valodas pareizība ir cieši saistīta ar viņa sociālo „pareizību”, ar viṇa piederību attiecīgam sabiedrības slānim;

2) uz valodu orientētais preskriptīvisms - raksturīgs Latvijai un vairākām līdzīgām zemēm un tautām, kur valodas pareizības un tīrības sargāšana bieži tikusi uztverta kā simbols nacionālai atmodai un pretestìbai pret svešu varu un citas valodas dominanci;

3) uz kḷūdu orientētais preskriptīvisms - daudzos gadījumos drīzāk psihologisku nekā politisku apstākḷu nosacīts preskriptīvisma 
veids (kas nākotnē būtu pelnījis vēl vairāk pētnieciskas iedzilināšanās). Tā ir koncentrēšanās uz „populārām”, t. i., bieži sastopamām vai bieži kritizētām īstām vai šḳietamām, kḷūdām; arī parādība, ko tautas mutē sauc par piekasīšanos pie vārdiem, bet kura (un kuras cēloṇi) nebūtu arī vienkārši noraidāma un ignorējama.

Kā šie trīs preskriptīvisma veidi pielāgojami tam, ko mēs zinām par Senās Romas situāciju un lingvistiskajām attieksmēm?

1. Uz cilvēku orientētais preskriptīvisms, kā šķiet, tai noteikti bijis raksturīgs. Jau minētais pētnieks R. Kasters ir sniedzis šādu kodolīgu vērtējumu: Gramatika skola piedāvāja to valodu un "mores" (tikumus, paradumus), pēc kuriem sabiedriskā un politiskā elite atpazina savus loceklıs (Kaster [1988] 1997, 14). Te var pieminēt arī daudzviet citētu Sidonija Apolinārija (Sidonius Apollinaris, m. è. 5. gs.) izteikumu Grammatica dividit (Gramatika dala/klasificēe no kādas vēstules (Epistula, 5.2.1). Kā norādījuši dažādi autori, šis teiciens liek domāt par dažādām interpretācijām - gan par to, kā gramatika sadala un klasificē valodas vienības un parādības, gan par to, kā gramatikas prasme vai neprasme sadala sabiedrību.

2. Uz valodu orientētais preskriptīvisms, kā sākumā varētu likties, vairāk ir raksturīgs nelielām, apspiestām lingvistiskām kopienām. Parasti tā arī ir, taču arī latīṇu valodā runājošie romieši, kas savulaik bija viena no ietekmīgākajām Eiropas tautām, nav iztikuši bez bažām par savas valodas likteni un domām par tās glābšanu. Kā norādījis M. Haimans, tam par iemeslu bija arvien pieaugošā lingvistiskā dažādība Romas impērijā, it ìpaši tās beigu posmā (..). 4. un 5. gadsimta autori-piemēram, Augustīns, kā arī gramatiķi Konsentijs un Pompejs - ir pieminējuši neliterārās iezìmes tajā latīnu valodā, kuru runāja Âfrikas provinču iemītnieki, galli, grieķi u. c. (..). Nav nekāds brīnums, ka preskriptīoa gramatika parādās kā atbilde uz sabiedriskiem procesiem (Hyman 2002). Arī Seviḷas Izidors (San Isidoro de Sevilla, Isidorus Hispalensis, ap 560.-636. g.) savā darbā Etymologiae jeb Origines (IX 1.7) norādījis jau ar distancētu atskatu pagātnē, ka impērijas laikmetā latīnu valoda bija "sajaukta” (mixta), jo dažādas jaunas paražas un citas tautības ieplūda Romas valstī, sabojājot [latīnuu] vārdu tīrìbu jeb veselumu ar barbarismiem un solecismiem, t. i., kḷūdām (integritatem verbi per soloecismos et barbarismos corrumpens). 
3. Arī uz kḷūdu orientētajam preskriptīvismam bija sava un nebūt ne maznozīmīga vieta seno romiešu rūpēs par valodas pareizìbu. Kā zināms, antīkajā pasaulē tika izšķirti divi valodas kḷūdu veidi - barbarismi (kḷūdaini vārdi) un solecismi (kḷūdainas konstrukcijas vai teikumi). Daiḷrunīgs ir arī vitia elocutionis (runas netikumu) jēdziens, ar ko apzīmētas dažāda veida valodas kḷūdas un kam liela uzmanība pievērsta Kvintiliāna jau iepriekš minētajā slavenajā darbā, jo, viṇaprāt, pirmais tikums ir izvairīties no netikumiem/klu ūām (prima virtus est vitio carere) (Institutio oratoria, VIII, 3, XLI). Valodas kḷūdu aprakstam pievērsies arī 4. gadsimta gramatiḳis Donāts (Aelius Donatus, 4. gs.) savā gramatikas grāmatā Ars maior. Runājot par valodas kultūrai veltītajiem antīko autoru apcerējumiem, zīmīgs ir Ilzes Rūmnieces vērtējums: Ne jau konsekventi un nebūt ne sistematizētā veidā [tajos] tiek norädìts uz (..) pareizajiem variantiem, iespējamo normu. Nereti tā noprotama no iztirzātajām izteiksmes kḷūdām - „vitia“ (Rūmniece 2005, 215). Nudien, mūsdienās varētu rasties jautājums: vai tad pārlieka koncentrēšanās uz nepareizo veicina pareizā apguvi?... Tomēr dažādos laikmetos un kultūrās valodas kḷūdas bieži ir izmantotas mācību procesā - gan kā negatīvs piemērs, gan kā dažādu vingrinājumu objekts (sk. Strelēvica-Ošiņa [2011] 2012, 100-103).

\section{CIK PAREIZI IZGLĪTĪBA SARGĀ VALODU?}

Visiem trim aprakstītajiem preskriptīvisma veidiem ir ciešs sakars ar izglìtību un pedagoǵiju - gan latīnu un latviešu valodas, gan citu valodu kontekstā. Vērtēt kādu parādību kā pareizu vai arī kā nepareizu, kḷūdainu - šis akts pats par sevi jau ietver pamācišanas, izglītošanas aspektu. Gramatikas un valodas mācību grāmatās (gan Senajā Romā, gan Latvijā, gan citur) tradicionāli bieži vien ir izmantoti citāti no attiecīgajā kultūrā ievērojamu rakstnieku darbiem, tādējādi papildus izglītojot arī literatūras un kultūrvēstures jomā. Visbeidzot, pedagogiija jebkurā gadījumā nozīmē zināmu vērtību tālāknodošanu, kopīgas identitātes veidošanu, un pareiza valoda bieži vien tiek uztverta kā tās pamats.

Kā zināms, Rietumu pasaulē, it ìpaši angḷu valodas vidē, kopš 20. gadsimta pirmās puses preskriptīvisms bieži ir ticis kritizēts kā negatīva parādība (ar pamatojumu, ka valodas dabiskajai attīstībai nedrīkst uzspiest nekādus vērtējumus par „pareizību” vai "tīrību”), tāpēc arī 
tradicionālajā izglītības sistēmā valdošā preskriptīvā pieeja valodai tika nosodīta. Šì iemesla dēl, piemēram, Lielbritānijā 20. gadsimta 60. gados notika krišana otrā galējībā un gramatikas mācǐšana praktiski tika izslēgta no skolu programmām. Šīs rīcības sekas tika apjaustas un daḷēji novērstas tikai 20. gadsimta beigās, bet tas jau ir cits stāsts (par to vairāk sk., piemēram, Crystal [2006] 2007, 201-206).

Latviešu kultūrvidē situācija bija diezgan atškirīga - rūpes par valodas pareizību bija izglìtības procesa neatṇemama sastāvdaḷa līdz pat gluži neseniem laikiem (20. gadsimta 90. gadiem, kad akadēmiskās gramatikas mācīšanu lielā mērā nomainīja t. s. komunikatīvā pieeja). Pirmās Latvijas republikas laika izglītības metodiķis Viktors Ramāns savulaik rakstīja: Valodas mācība jeb gramatika ir valodas tīrības sargātāja: ar zinātnisku pan̄ēmienu palīdzību tā cenšas valodu pasargāt un tìrìt no nepiemērotām pārmain̄ām un citu valodu piejaukumiem. Valodas mācība sakārto un sistematizē dažādās valodas formas un parādības un atrod tām kopīgus likumus (Ramāns 1938, 11). Šis citāts liekus komentārus neprasa - no mūsdienu viedokḷa varbūt pārspīlētais uzsvars uz preskriptīvo aspektu tomēr pauž vislabākos nodomus, un ideja par gramatikas skolotāju kā valodas sargu jeb custos sermonis šeit pilnā mērā seko klasiskajiem paraugiem.

Ja atceramies arī Augustīna doto apzīmējumu gramatiḳim - custos historiae (vēstures/tradīcijas sargs), rodas jautājums, kas ar gramatikas un valodas pareizības mācīšanas vadmotīviem notiek politisku pārmaiṇu laikos, kad historia nereti tiek rakstīta no jauna?... Kā liecina lingvodidaktikas speciālista Normunda Dzintara pētījumi, tad latviešu valodas mācību programma arī pēc padomju okupācijas lielā mērā līdzinājās brīvvalsts laiku programmai. Kaut arī tika uzsvērts, ka nacionālā audzināšana jānomaina pret internacionālo, tomēr, piemēram, 1940. gadā sastādītā programmā ticis norādīts, ka latviešu valodas priekšmeta galvenais mērḳis ir iemācīt skolēnus runāt un rakstìt pareizā un tīrā valodā, kā arī nostiprināt viṇos mīlestību un cieņu pret savu valodu (Dzintars 2012). Un 60 gadus vēlāk, kad politiskā iekārta jau atkal ir mainījusies, cita šīs jomas pētniece Diāna Laiveniece raksta, joprojām paužot līdzīgas domas:

Ir pienācis laiks, kad jāliek prāti kopā, kad visiem, kam rūp mūsu valodas kvalitatīolietojums (..), ir jāizsaka savas domas (..) par to, kas būtisks jāmaina dzimtās valodas $k \bar{a}$ skolas mācību priekšmeta saturā, metodikā, mācību lìdzeklos (..), lai tiešām skolā latviešu bèrni mācītos latviešu valodu un, skolu 
pabeiguši, prastu ar cieņu un godu šo valodu pareizi lietot (Laiveniece 2000, 49; izcēlums mans - D. S.-O.).

Vai gan tas nozīmētu, ka visu laiku līdz tam mācīšana būtu bijusi neveiksmīga? Protams, ne visi beidz skolu, ar mīlestību un cieņu lietodami "pareizu” valodu, un tā tas ir bijis visos laikos. Taču te lielāka nozīme ir tam, kā izglìtības pieredze ir iespaidojusi ne tik daudz praktisko valodas lietojumu latviešu sabiedrībā, bet tieši attieksmi pret valodu. Padomju okupācijas apstākḷos par spīti valdošajai ideologijai, kas vērsās pret nacionālajām vērtībām, latviešu izglìtības sistēma un arī citas ar valodu saistītās nozares spēja saglabāt un uzturēt tradicionālo ideju, ka mīlestībai pret dzimto valodu ir jābūt un ka gramatiski pareiza un tīra valoda ir arī citu vērtību (tai skaitā nacionālās identitātes) simbols. (Par padomju laikiem raksturīgo valodas preskriptīvismu Latvijā un to, kāda loma tam bija latviešu nacionālās pašapziṇas saglabāšanā, vairāk sk.: Strelēvica-Ošiņa [2011] 2012.)

Kā daudzās jomās, tā arī valodas mācǐšanā un attieksmē pret valodu - pedagoga rokās ir liela atbildība un iespēja gan paveikt svētīgu darbu, gan arī pieḷaut lielu kḷūdu. Diskusijās par latviešu valodas pareizības jautājumiem (gan dzīvē, gan internetā) cilvēki nereti atsaucas uz skolas laikā apgūto un uz saviem kādreizējiem pamatskolas vai vidusskolas skolotājiem kā vienīgo un galveno autoritāti. Īpaši fanātiski tas tiek darīts tad, ja kopš skolas beigšanas nekad vēlāk mūžā viņiem vairs nav nācies saskarties ar valodas jautājumu aplūkošanu no teorētiska skatpunkta. Šāda nostāja ir gan pozitīva (jo rāda, ka cilvēks apzinās izglītības vērtību), gan arī negatîva. Jo tādējādi bieži vien tiek nekritiski aizstāvētas novecojušas vai piln̄̄gi nepamatotas normas un veicināts īsts preskriptīvisms šì vārda sliktākajā nozīmē, nereti pat balstīts uz pārpratumiem vai kādiem individuāliem subjektīviem viedokḷiem (kas savulaik piemituši pārcentīgam vai neprofesionālam skolotājam vai arī viņa audzēknim). Būtu labi, ja katrs valodas skolotājs sniegtu saviem skolēniem arī plašāku skatījumu uz valodu un spēju novērtēt tās dažādību (piemēram, paralēlās formas, no kurām ne vienmēr tikai viena ir jāuzskata par pareizo; pārnestās nozīmes, jaunu vārdu un nozīmju rašanos utt.).

Galu galā vienmēr jāpatur prātā arī šāds fakts - latīṇu valoda, kuras mācīšanā gadu tūkstošu gaitā nav trūcis preskriptīvu, fanātisku rūpju par valodas pareizību, diemžēl vairs nefunkcionē kā dzìva, ikdienā lietota valoda. Vai savai valodai mēs šādu likteni vēlamies?... 


\section{BIBLIOGRĀFIJA}

Augustinus Hipponensis. De musica, 2.1.1. Quoted in: J. N. Adams. Social Variation and the Latin Language. Cambridge : Cambridge University Press, 2013, 44.

Crystal, David. The Fight for English. How Language Pundits Ate, Shot, and Left. Oxford University Press, [2006] 2007.

Dzintars, Normunds. Akcentu maiṇa latviešu valodas mācību sistēmā padomju okupācijas sākumposmā. Via scientiarium: starptautiskās jauno lingvistu konferences rakstu kräjums, 1. laidiens. Ventspils, Liepāja : Ventspils Augstskola, Liepājas Universitāte, 2012, 77.-94. lpp.

Hyman, Malcolm D. Bad Grammar in Context. New England Classical Journal 29 (2), 2002 [cited 9 February 2003]. Available: $h t t p: / / a r c h i m e d e s . f a s . h a r v a r d . e d u / m d h /$

Isidorus Hispalensis. Etymologiae (Origines), Liber IX [cited 5 April 2013]. Available: http:// penelope.uchicago.edu/thayer/e/roman/texts/isidorel

Kaster, Robert A. Guardians of Language: the Grammarian and Society in Late Antiquity. University of California Press, 1997.

Laiveniece, Diāna. Dzimtās valodas kā mācību priekšmeta misija mūsdienu latviešu skolā. Valoda zinātnē un izglìtībā. Akadēmiḳa Jāna Endzelīna 127. dzimšanas dienas atceres starptautiskās zinātniskās konferences materiāli. LU Latviešu valodas institūts, 2000, 46.-50. lpp.

Quintilianus, Marcus Fabius, Institutio Oratoria, Liber I: 4, 2 [cited 1 January, 2002]. Available: http://www.thelatinlibrary.com/quintilian/quintilian.institutio.shtml

Ramāns, Viktors. Latviešu valodas metodika pamatskolām. Otrs izdevums (pārlabots un papildināts). Rīga : Latvijas Vidusskolu Skolotāju Kooperātīva izdevums, 1938.

Rūmniece, Ilze. Vitia elocutionis: valodas kḷūdas antīkās vārda mākslas teorētiḳu skatījumā (Kvintiliāns). Antiquitas Viva 2. Studia Classica: Urbs aeterna. Rīga : Zinātne, 2005, 214.-227. lpp.

Seneca, Lucius Annaeus. Epistula 95.65. Quoted in: R. A. Kaster, 1997, 17.

Sidonius Appollinaris. Epistula 5.2.1. Quoted in: R. A. Kaster, 1997, 19.

Strelēvica-Ošiṇa, Dace. Valodas pareizības izpratne un preskriptìvisma cēloni un sekas: Latvijas un pasaules pieredze. Promocijas darba kopsavilkums. / Perception of Language Correctness and Causes and Effects of Prescriptivism in Latvia and the World. Summary of the Doctoral Thesis. [A bilingual publication]. Rīga : Latvijas Universitāte, 2010.

Strelēvica-Ošiña, Dace. Kāpēc mēs gribam, lai valoda ir pareiza? Ieskats preskriptìvisma vēsturēe, teorijā un praksēe. Rīga : LU Latviešu valodas institūts, [2011] 2012.

Suetonius, Gaius Tranquillus. De grammaticis, 22 [cited 1 October, 2012]. Available: http:// www.thelatinlibrary.com/suetonius/suet.gram.html 
Dace Strelēvica-Ošiņa, Latvian Language Institute of the University of Latvia, Latvia

CUSTOS SERMONIS (GUARDIAN OF LANGUAGE): AN INSIGHT INTO THE PERCEPTION OF NATIVE LANGUAGE INSTRUCTION IN LATIN AND LATVIAN TRADITIONS

This article looks at the phenomenon of prescriptivism which is typical to numerous linguistic communities - the approach that attempts to preserve the "correctness" and "purity" of language by strictly following prescriptive norms. Giving an insight into my recent theory of the three basic types of prescriptivism (human-oriented, language-oriented, and error-oriented), I particularly attempt to highlight certain aspects of prescriptivism that relate to the field of education and language instruction.

Both the Ancient Roman and the 20th-21st century Latvian societies have cherished the idea of the teacher of native language and grammar as the custos sermonis, i.e. the guardian of language, and also the shaper of a person's identity. The important role of the language teacher, however, can become a double-edged sword - from someone who guides others towards genuine knowledge and love for their language, to a perpetuator of linguistic stereotypes and misconceptions. 


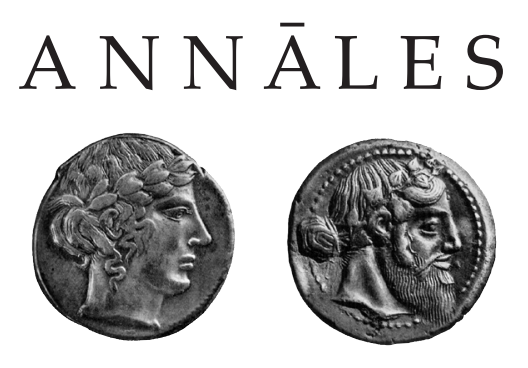

\section{VARIA}

\section{KLASISKĀS FILOLOĢIJAS STUDIJU PROGRAMMAS LU 21. GADSIMTA OTRAJ Ā DESMITGADE}

Pagājuši jau vairāk nekā 20 gadi kopš Klasiskās filologijas bakalaura un maǵistra studiju programmu atjaunotnes Latvijas Universitātē (LU). Tādējādi līdzīgi kā LU pirmsākumos, arī tagad Latvijā ir iespēja akadēmiskā līmenī studēt abas klasiskās valodas - latīṇu un sengrieķu - un iepazìt daudzveidīgo antīkās pasaules kultūrmantojumu, jo sevišḳi - literatūru.

Laika gaitā programmās un studiju procesā daudz kas mainīts, cenšoties pielāgoties mūsdienu izglītības vides nostādnēm un prasībām, taču vienlaikus mēǵinot arī saglabāt klasiskās filoloǵijas jomā būtisko un unikālo.

Klasiskās filologiijas bakalaura un maǵistra programmas ir akreditētas jau trešo reizi, tās nodrošina Humanitāro zinātṇu fakultātes (HZF) Klasiskās filologijias katedras docētāji līdz ar pasniedzējiem no citām katedrām, nodaḷām un arī fakultātēm. Intensīvas trīs gadu pamatstudijas ḷauj studentiem iegūt humanitāro zinātņu bakalaura grādu filoloǵijā, vēl divos augstākā līmeṇa studiju gados nonākot līdz humanitāro zinātṇu maǵistra grādam.

Studijas sākas ar intensīvu latīnu un sengrieķu valodas gramatisko pamatlikumību un bagātīgās leksikas minimuma apguvi, kā arī tekstu iepazišanu un pirmo tulkošanas prasmju apguvi¹. Pirmais mācību gads

1 Latīnu valoda, Sengrieķu valoda, Tekstoloǵiskā analīze: latīnu proza un dzeja, Tekstoloǵiskā analīze: sengrieku proza un dzeja. 
sniedz daudzveidīgu ieskatu dažādos ievadkursos² gan plašāk filoloǵiskās pamatnostādnēs, gan tieši antīkās pasaules vēstures un kultūras, literatūras un mitologiijas specifiskās raksturiezīmēs, l̦aujot pamazām veidoties vispusīgai izpratnei par antīkās pasaules unikālo kultūrvidi un klasiskās filologiijas savdabību, bet vienlaikus arī tās nemainīgo un nezūdošo vērtību visu vēlāko gadsimtu Eiropas kultūrnorisēs un jo îpaši - filoloǵijas jomā.

Turpmākie pamatstudiju gadi nodrošina padziḷinātu zināšanu un prasmju apgūšanu. Specializētie, noteiktiem valodas aspektiem veltītie Latīnuu/grieķu leksikoloǵijas un Sengrieķu/latīņu sintakses kursi ḷauj padzilināt klasisko valodu zināšanas un prasmes, arvien vairāk apjaušot šo valodu burvību un vienlaikus arī vispārlingvistisko nozīmi. Plaši atsevišķiem literatūras žanriem ir veltīti Antīkā eposa, Klasiskās grieķu oratorprozas, Romiešu retoriskās prozas, Antīkās dialoǵiskās prozas kursi, kā arī tālāk piedāvātie Antīkās lirikas, Antīkās drāmas, Antīkās vēsturiskās prozas tradīcijas, Mitoloǵiskās tradīcijas romiešu dzejā un Viduslaiku latīnu tekstu kursi, kas sniedz zināšanas par daudzveidīgo Senās Griekijas un Romas autoru (Homēra un Sofokla, Vergilija un Cicerona, Platona un Horācija un daudzu citu) literāro mantojumu, dažādo tekstu un tajos rodamo domu, ideju, formu un māksliniecisko paṇēmienu bagātību, kas neiztrūkstoši arvien radušas tādu vai citādu atbalsi arī vēlāko laiku literārajā jaunradē. Savukārt Antīkās filozofijas vēstures un Antīko filozofisko tekstu kursi iepazīstina ar nozīmīgākajām antīkās pasaules filozofiskajām nostādnēm un idejām.

Bez jau akadēmiskā līmenī papildinātām angḷu valodas zināšanām pirmajā kursā studentiem nākamajos gados ir iespēja apgūt vienu izvēlēto moderno svešvalodu (piem., spāņu, franču), kā arī nodrošināta Latvijā unikāla iespēja vairāku semestru garumā apgūt jaungrieķu valodu, kuras zināšanas tālāk ne viens vien studējošais izmanto un papildina Grieḳijā.

Savukārt Klasiskās filoloǵijas maǵistra programma piedāvā antīkās kultūras, klasisko valodu un dažādu antīkās literatūras žanru iepazīšanu un vērtību izpēti padziḷinātā un paplašinātā starpdisciplinārā, vispārteorētiskā un kulturologiiskā kontekstā, uzmanību pievēršot arī recepcijas aspektam. To nodrošina daudzveidīgais studiju kursu piedāvājums, starp kuriem var minēt, piemēram, tādus kursus kā Stilistika un tekstveide, Literatūrpētniecības metodes XX gs., Antīkā kultūrmantojuma

2 Ievads literatūrzinātnē, Ievads valodniecībā, Ievads antīkajā pasaulē, Senās Griekijas un Romas vēsture, Antīkā mitoloǵija, Ievads Rietumu literatūrā. 
recepcija, Grieķu/latīņu valodas vēsture, Klasisko tekstu stilistika, Antīkais eps: tipoloğiskais aspekts, Antīkās historiogräfijas metodes, Romāna žanrs antīkajā literatūrā, Epistulāro tekstu tradīiija, Aluzivitāte romiešu literatūrā, Simposija literatūras tradīcija Grieķijā, Skaistuma kategorija sengriek,u kultūrā, Ievads bizantoloǵijā, Mūzikas kulturoloǵija, Mitoloǵija mūsdienu literatūrā, Publiskās runas pamati u. c.

Neatṇemama akadēmiskās dzìves daḷa ir zinātniski pētnieciskās aktivitātes. Klasiskās filologijas programmu studenti attīsta zinātniskā darba prasmes, sākot ar bakalaura programmā obligāto kursa un bakalaura darbu, maǵistra programmā - maǵistra darba izstrādi, un tālāk iesaistoties plašākās aktivitātēs, izstrādājot zinātniskus referātus un piedaloties studentu zinātniskās konferencēs, līdzdarbojoties dažādos pētījumos.

Tā, piemēram, LU HZF XI Studentu starptautiskajā zinātniskajā konferencē (2012. gada 18.-19. aprīlī) referātus nolasìja vairāki klasiskās filoloǵijas programmu studenti: Eva Folkmane (Sievietes tēla sistēmiskā koncepcija Homēra "Odisejā"), Artis Oltre (Salu loma Homēra "Odisejā"), Patrīcija Patmalniece (Vēstìtājs Cēzara "Piezīmēs par gallu karu”). Savukārt 2013. gada 9.-10. maijā starptautiskā zinātniskā konferencē Konteksta nozìmīgums mūsdienu humanitārajās zinātnēs Kristīne Krinǵgele nolasīja referātu Dievu nozìme Hēsioda poèmā "Darbi un dienas".

Studenti līdzdarbojas gan projektā Literatūrzinātnes un lingvistikas antīkie avoti: Aristotel̦a "Rētorika" (tulkojums, zinātnisks komentārs, pētījumu kopa), gan projektā Viduslaiku latīnu teksti Livonijā: A. Eicēdija poēma "Aulaeum Dunaidum" (tulkojums, zinātnisks komentārs, zinātniski raksti), tāpat arī Baltijas jūras regiiona universitāšu klasisko filologu zinātniskās sadarbības projektā Colloquium Balticum.

Orientējoties uz studentu un jauno zinātnieku aktīvu iesaisti pētniecībā, 2013. gadā LU zinātniskās konferences ietvaros tika aizsākta iepriekš nebijusi tradīcija: klasiskās filologiijas pētnieku un studentu līdzdalība noteiktu tēmu izstrādē, kā rezultātā LU 71. konferences Klasiskās filologijas sekcijas "De profundis" valodniecībā un literatūrzinātnē (28.02.2013.) sēdē tika nolasīti vairāki studentu un docētāju koreferāti. Sēdes mērḳis bija klasisko/stabilo literatūrzinātnes un valodniecības vērtību apzināšana dažādos antīkās pasaules tekstos, kā arī šo vērtību recepcijas meklējumi jaunāku laiku sacerējumos. Tā, piemēram, bakalaura programmas 3. kursa studente Eva Folkmane, sadarbojoties ar doktoranti Ilonu Gorņevu, referēja par sieviešu tēlu sistēmisko koncepciju Homēra tekstos, maǵistrante Kristina Jemeḷjanova kopā ar 


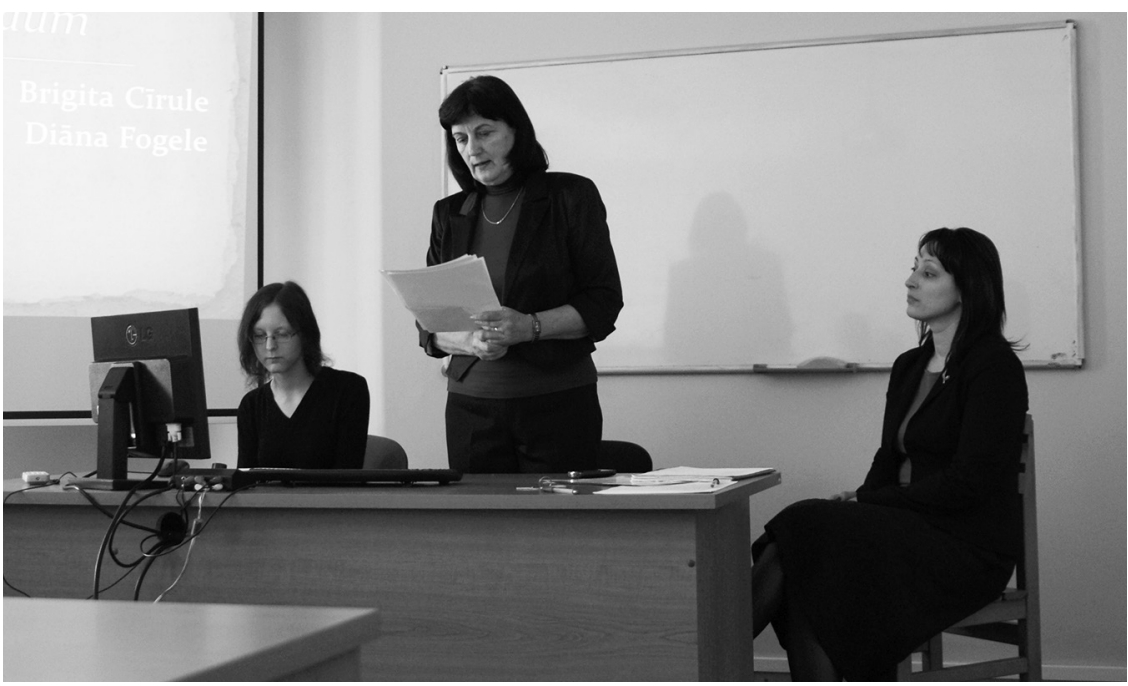

Latvijas Universitātes 71. konference, Klasiskās filologijas sekcija "De profundis" valodniecībā un literatūrzinātnē

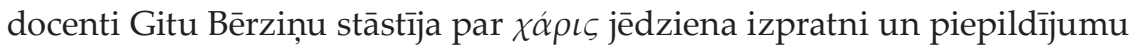
sengrieḳu dzīru kontekstā, kā to atklāj arhaiskā perioda eposa un lirikas liecības, bet I. Gorņeva, doktorante Liva Bodniece un maǵistrants Toms Herings kopā ar profesori Vitu Paparinsku uzmanību bija pievērsuši apjomīgajai tēmai par rētoriku literārā tekstā, konferencē sniedzot ieskatu dažādos šai tēmai būtiskos aspektos un dažādu autoru/žanru tekstu raksturiezīmēs. Saistošas idejas atklāja doktorantes Ievas Fībigas un profesores Ilzes Rūmnieces referāts par „poētisko nepoētiskajā”, t. i., par dažādu valodas faktu/elementu/paṇēmienu izmantojumu antīkajos zinātniskajos sacerējumos, bet maǵistrante Diāna Fogele kopā ar docenti Brigitu Cīruli ḷāva ielūkoties mītisko elementu funkcionēšanā daudz vēlāku gadsimtu tekstā - Livonijas Augustīna Eicēdija poēmā Aulaeum Dunaidum. Maǵistrants Mārtiņš Laizāns runāja par Aristoteḷa Poētikas literatūrteorētisko jēdzienu latviskošanas iespējām, izskanot ne vienai vien rosinošai un pat provokatīvai domai, savukārt profesors Ojārs Lāms meklēja „kārtējo/mūžīgo Odiseja ceḷu” Jura Zvirgzdiṇa stāstu krājumā Atgriešanās Itakā.

Studiju laikā klasiskās filologijas bakalaura un maǵistra programmu studentiem ir arī iespēja piedalīties kādā no starpuniversitāšu apmaiņas programmām vai vasaras skolām. Līdz šim visplašāko atsaucību guvusi

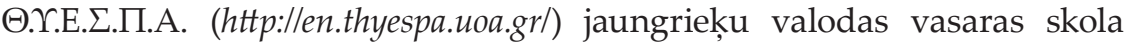




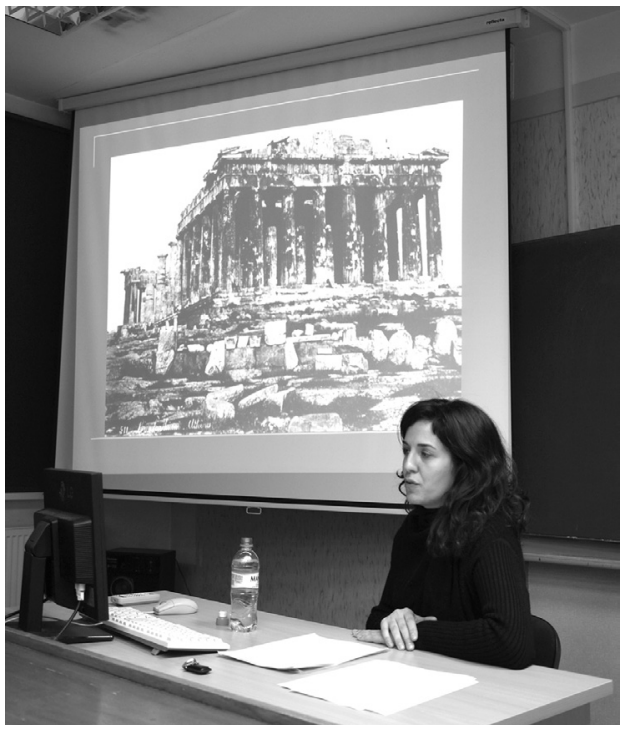

Despinas Katapoti (Grieḳija) vieslekcija

Atēnās, Grieḳijā, kurā ik gadu diviem klasiskās filologijas studentiem no Latvijas tiek pieškirtas stipendijas. Šì vasaras skola sākas jūnija sākumā un ilgst sešas nedēlas. Otra jaungrieḳu valodas vasaras skola, uz kuru augustā dodas klasiskās filologijas studenti, ir Balkānu studiju institūta organizētā Starptautiskā jaungrieḳu valodas, grieķu kultūras un vēstures vasaras skola IMXA (Tesalonīkē, Griekijā) (http://wwww.hyper.gr/imxa/). Klasiskās filoloǵijas bakalaura un maǵistra studiju programmas ir gatavas arī uzṇemt apmaiņas studentus Erasmus u. c. apmaiņas programmu ietvaros.

Katru gadu Klasiskās filologiijas programmu studentiem ir iespēja papildināt zināšanas, klausoties viesdocētāju lekcijas. Tā, piemēram, 2012./2013. akad. g. pavasara semestrī programmas bagātināja divi vieslekciju cikli. Vispirms Erasmus docētāju mobilitātes ietvaros februāra beigās Rīgā viesojās Egejas Universitātes (Grieḳija) lektore Despina Katapoti ( $\triangle \dot{\varepsilon} \sigma \pi o \iota v \alpha K \alpha \tau \alpha \pi o ́ \tau \eta)$. Viṇa nolasìja trīs lekcijas par grieḳu identitāti, tās apmeklēja un augstu novērtēja ne tikai Klasiskās filologijas studiju programmu studenti, bet arī Kultūras un sociālās antropoloǵijas maǵistra studiju programmas studenti un interesenti no Vēstures un filozofijas fakultātes studiju programmām.

Savukārt aprīḷa beigās ar Erasmus docētāju mobilitātes atbalstu Klasiskās filologijas bakalaura studiju programmā saistošas lekcijas par romiešu mākslu nolasīja Dr. Audrone Kučinskiene no Viḷnas 


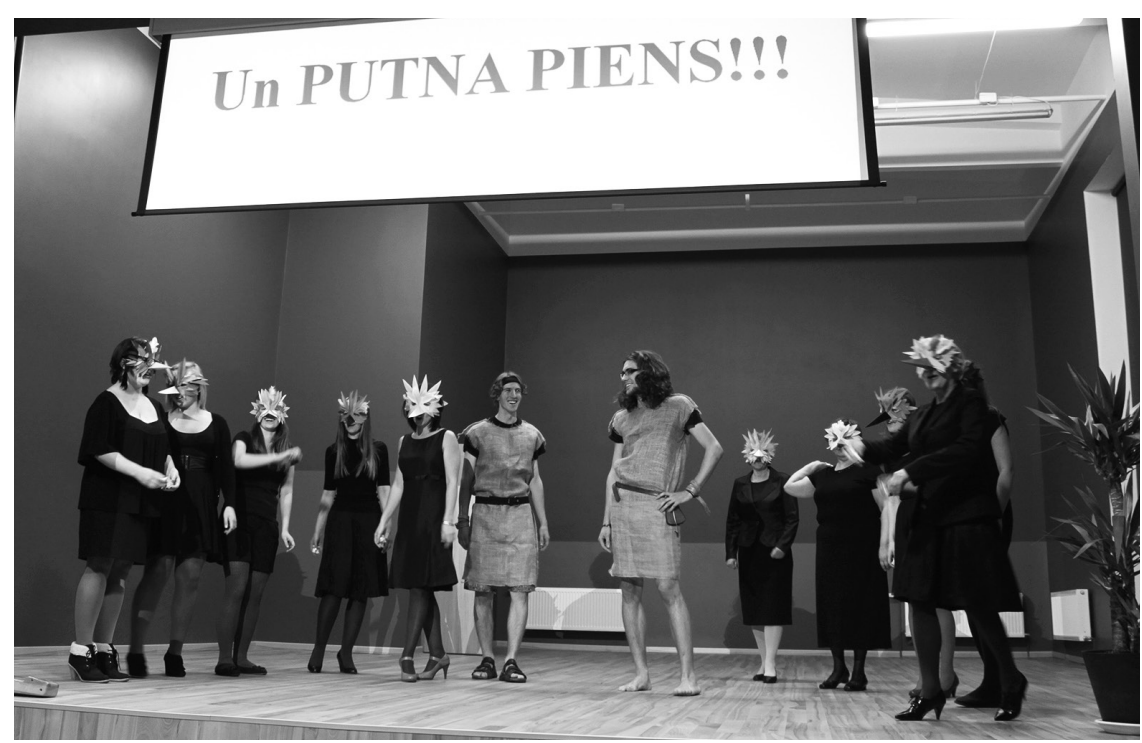

Zinātnieku nakts 2012, Aristofana lugas Putni iestudējums

Universitātes. Lekciju materiāls bija papildināts ar autores pašas Romā uzṇemtām fotogrāfijām un videomateriāliem. A. Kučinskiene nolasīja arī vienu Cicerona pētniecībai veltītu lekciju Klasiskās filologiijas magistra studiju programmā. Jāatzīmē arī, ka līdzās akadēmiskajam un pētnieciskajam darbam Klasiskās filoloǵijas katedrai piederīgie aktīvi līdzdarbojas dažādās kultūras aktivitātēs un citos sarīkojumos, popularizējot antīkās kultūras mantojumu LU un ārpus tās.

Akadēmisko aprindu neatslābstošo interesi par antīko pasauli un klasiskajām valodām pierāda fakts, ka atkārtoti rudens semestrī tiek piedāvāts un lielu popularitāti izpelnās Klasiskās filologiijas katedrā izstrādātais brīvās izvēles C daḷas kurss Sengrieķu valodas elementārkurss I. 2012. akad. gada ruden̄i uz to bija pieteikušies 45 studenti no visdažādākajām LU fakultātēm, to skaitā no Datorikas, Medicīnas, Teologijas, Biologijas, Pedagogijas, psihologijas un mākslas fakultātes.

Klasiḳi labprāt sadarbojas ar dažādām LU struktūrvienībām, sniedzot savu ieguldījumu to rīkotajos pasākumos. Tā 2011./2012. akad. gadā Klasiskās filologiijas katedras mācībspēki un studenti ar izglītojošiem ievadvārdiem un atraktīviem priekšnesumiem piedalījušies LU Bibliotēkas rīkoto seno grāmatu izstāžu svinīgajā atklāšanā: Vārds likumam 16.-17. gs. tiesību avoti un Antīkās literatūras pasaulē. Tāpat Klasiskās 


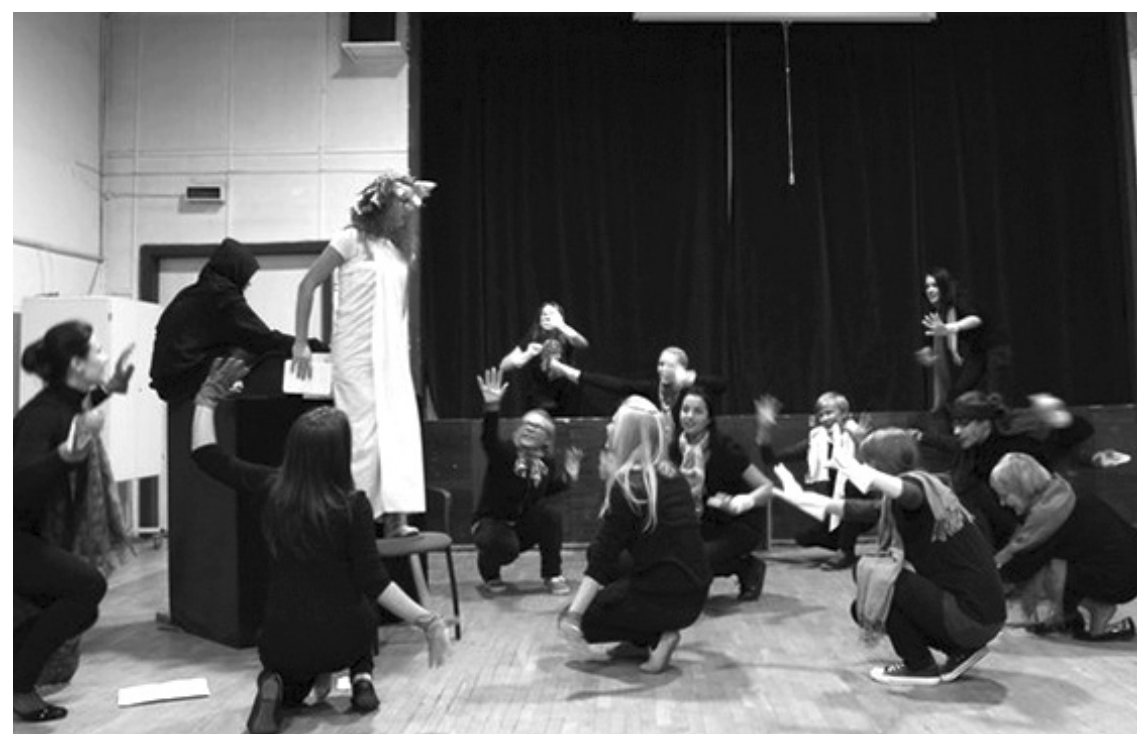

Zinātnieku nakts 2011, Aristofana lugas Vardes iestudējuma tapšana

filologijas magistra studiju programmas absolventes L. Bodniece, Laura Freidenfelde un I. Gorņeva ar latīṇu autoru atdzejojumiem bagātināja dzejas lasījumus LU Botāniskajā dārzā.

Pēc nelielas pauzes arī teātra trupa LUDUS ACADEMICUS, kuru veido LU HZF dažādu kursu studenti un mācībspēki, atsākusi aktīvu darbību.

Zinātnieku nakts 2011 ietvaros LU HZF Hellēnistikas centrs un Klasiskās filologiijas katedra rīkoja sengrieḳu drāmas uzvedumu meistarklases Antīkās trağēdijas un komēdijas ķīmija mūsdienās. Meistarklases vadīja režisore no Atēnām Maria Luiza Papadopulu (M $\alpha \rho i \alpha-\Lambda o v i \zeta \alpha$

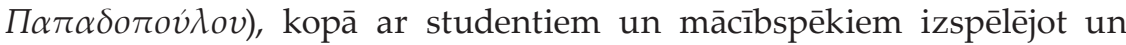
origininālvalodā iestudējot fragmentus no Aristofana komēdijas Vardes.

Savukārt 2012./2013. akadēmisko gadu klasiḳi ieskandināja, augusta beigās viesojoties pie saviem ilggadējiem sadarbības partneriem Viḷnas Universitātes Klasiskās filologiijas katedrā un iepriecinot sagaidītājus ar Aristofana komēdijas Putni interpretāciju oriǵinālvalodā, lomās iejutās gan pasniedzēji, gan studenti.

Iesakṇojusies un par tradīciju kḷuvusi arī klasiķu eglìte - katru gadu īsi pirms svētku brīvdienām katedra rīko klasik,u Ziemassvētku eglīit, uz 
kuru tiek aicināti Klasiskās filologijas studiju programmu studenti un pasniedzēji, katedrai piederīgie, absolventi un klasiku draugi.

Klasiskās filolog̣ijas programmas mūsdienu izglītības vidē piedāvā stabilas un mūžam aktuālas vērtības, un tā ir neatņemama LU, un patiesībā - visas Latvijas, akadēmiskās dzīves daḷa. Ar katru gadu palielinās klasiskās filologijas studiju absolventu skaits, un katrs no viniiem ir šo vērtību nesējs Latvijas sabiedrībā neatkarīgi no jomas, kurā darbojas pēc diploma iegūšanas.

Gita Bērziña, Lìva Bodniece

\section{COLLOQUIA BALTICA (2010-2012)}

Latīnu valodas leksēma traditio, parasti latviskota kā tradīcija, ietver plašu nozīmju spektru - traditio ir gan saskare un apmaiņa, gan tālāknodošana, gan nodošana glabāšanā. Projekts Colloquium Balticum ir tradīcija visās šajās nozīmēs.

Colloquium Balticum, Baltijas jūras reǵiona universitāšu klasisko filologu - mācībspēku un studentu - sadarbības projekts pēc Lundas Universitātes profesora Jerkera Blumkvista un Greifsvaldes Universitātes profesora Gregora Fogta-Špiras iniciatīvas aizsākās 2001. gadā. Kā projekta izveides pirmsākumos izlēma abi tā iniciatori un pieaicinātie Baltijas jūras valstu universitāšu klasisko filologu pārstāvji, projekta mērḳis ir pētīt antīkās pasaules daudzveidīgo kultūrainu un it īpaši antīkā kultūrmantojuma recepciju Baltijas jūras reǵionā. Projekts ir orientēts uz tradīciju - ne tikai pagātnes kultūrvērtību apzināšanu, bet arī uz to saglabāšanu un nodošanu nākamībai akadēmiskas saskares un domu apmaiṇas ceḷā.

Šì akadēmiskās saskares forma ir tradicionālās ikgadējās zinātniskās konferences. Colloquium Balticum Rigense IX notika 2010. gadā Rīgā, Latvijas Universitātē (LU), Colloquium Balticum Vilnense X - 2011. gadā Viḷnāā, Viḷnas Universitātē, Colloquium Balticum Lundense XI - 2012. gadā Lundā, Lundas Universitātē.

Tradīcija ir konferenču darba kārtības saturiskais strukturējums. Plašākā ir antīkās pasaules jautājumiem veltītā daḷa, kurā konferences dalībniekiem, uzklausot kādu maz zināmu antīkās pasaules kultūrfaktu vai paskatoties uz zināmo no savdabīga skatpunkta, ir iespēja vēlreiz pārliecināties par antīkā kultūrmantojuma tradīcijas esamību un tās nepieciešamību. Interesi rosinoši ir ziņojumi par antīkās kultūrtradīcijas 
ANNĀLES

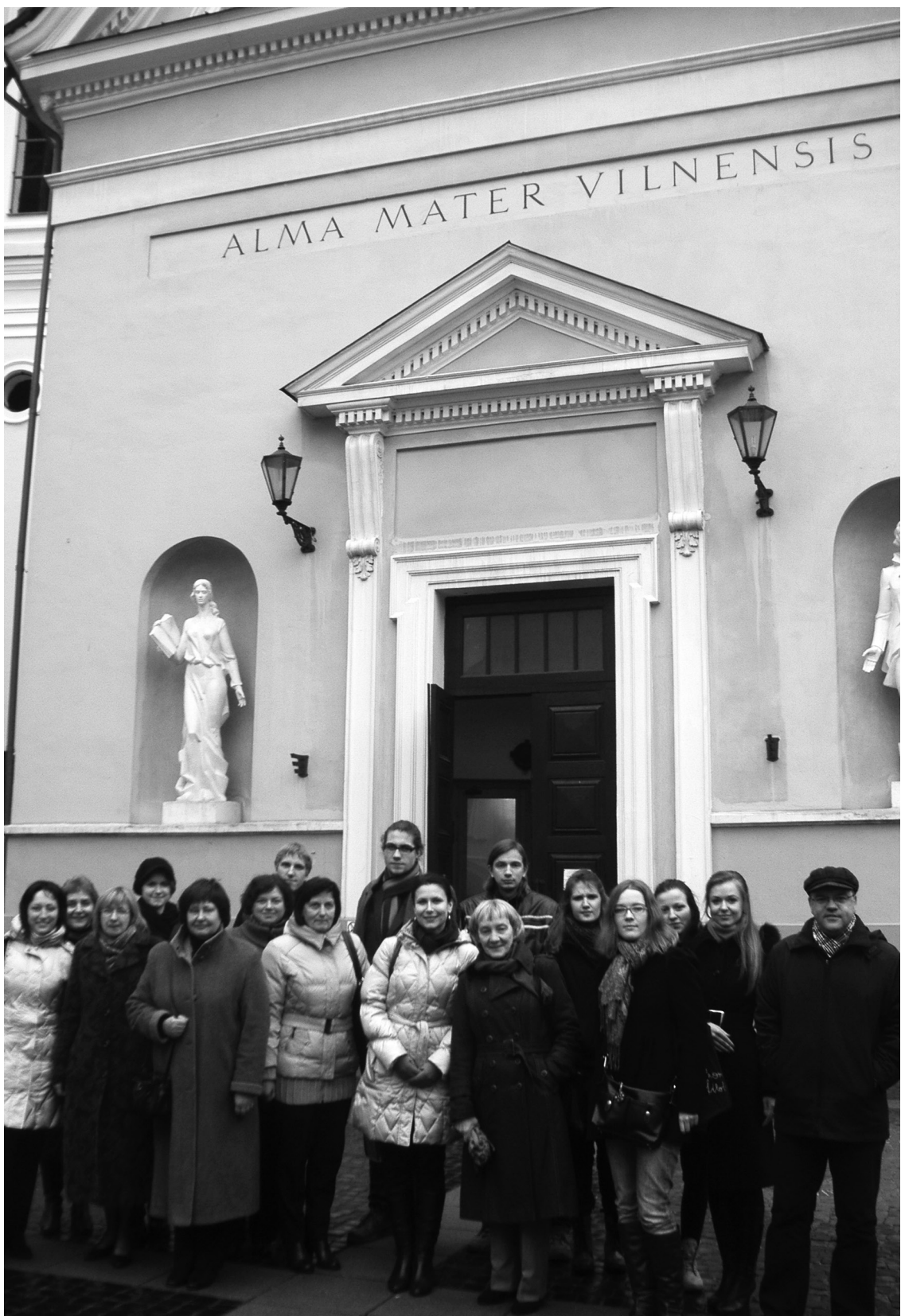

Latvijas Universitātes klasiskie filologi Viḷnas Universitātē 2011. gadā Colloquium Balticum Vilnense X laikā 
pārmantotību dažādās Baltijas jūras reǵiona valstīs. Antīkās tradīcijas recepcija jaunlaiku kultūrtelpā, dažkārt neierasti transformētā veidā, ir antīko kultūrvērtību saglabātības liecība.

Jau kopš projekta aizsākumiem tajā darbojas Latvija. Iztirzājot dažādus antīkās literatūras, grieḳu un latīṇu valodas un antīkās teorētiskās domas aspektus, konferencēs ar ziṇojumiem uzstājušies LU klasiskie filologi - profesore Vita Paparinska, profesore Ilze Rūmniece, docente Gita Bērziṇa. Klasiskās filologiijas recepcijas Latvijas kultūrtelpā aspektu pēta profesors Ojārs Lāms un profesore Ieva Kalniņa. Pārliecinošs ir jaunākās paaudzes klasisko filologu Brigitas Kukjalko un Ilonas Gorṇevas zinātniskā snieguma pieteikums.

2013. gadā Colloquium Balticum tradīcija turpinājās - Marburgā, Marburgas Universitātē notika Colloquium Balticum Marburgense XII. Tās jaunums - Georga Olmsa izdevniecībā tiek sagatavots pirmais Colloquia Baltica zinātnisko rakstu krājums.

Vita Paparinska

VOLATUS ACADEMICUS - AVES VILNENSES

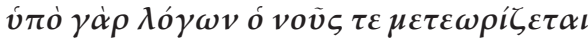

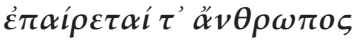 \\ no runām mūsu prāts pa gaisu lidot sāk \\ un gaisā ceḷas cilvēks
}

(Aristofans Putni, 1448-1449)

Latvijas Universitātes (LU) Humanitāro zinātṇu fakultātes (HZF) klasiskās filologijas studentu un mācībspēku apvienotā teātra trupa Ludus Academicus (profesores Ilzes Rūmnieces vadībā) saṇēma uzaicinājumu no Viḷnas Universitātes klasicistiem uzstāties ar viesizlidojumu 2012. gada 31. augustā Viḷnāa starptautiskajā divu dienu konferencē Euroclassica 2012 ar Aristofana joklugas Putni ('O $\rho v \iota \theta \varepsilon \zeta$ ) fragmentiem. Viḷnā Putni ne tikai parādīja sevi kā viendabīgu senatnes un mūsdienu skatuviskā lidojuma sakausējumu, bet arī kā pavisam drošu tiltu no konferences akadēmiski oficiālās daḷas uz vakara neoficiāli dionīsisko daḷu - simposiju. Tā teikt, otium post negotium!

Vērtīgi atgādināt, ka Ludus Academicus Aristofana Putnus dažādās variācijās kopumā ir izrādījis jau piecas reizes (sic!). Īsumā par Putnu 
saturu - tā ir garākā saglabājusies Aristofana jokluga un lielisks vecatiskās joklugas paraugs. Tā vēstī par diviem Atēnu dzīves nogurdinātiem jaunekḷiem Euelpidu un Pistetairu, kas vēlas doties labākas dzìves meklējumos (nevar nepamanīt līdzību ar mūsdienu Latvijas ikdienu, kad arī daudz jaunu cilvēku vēlas doties labākas dzìves meklējumos citur). Ar

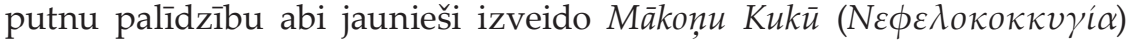
pilsētu debesīs, cenšoties pārn,emt varu no līdzšinējiem olimpiskajiem dieviem, kas arī viniiem izdodas. Līdz ar to luga noslēdzas ar priekpilnām dziesmām par iegūto varu un jaunuzcelto debesu valstību.

Putni savu izškilšanos piedzīvoja 2007. gada novembrī hellēn̨u viesrežisora Jorga Biniara ( Antigones un Eurīpida Helenes fragmentiem tika inscenēta arī īsa - Erota dzimšanas - aina no Aristofana Putniem Antīko dzejas dienu ietvaros. Pirmo lidojumu jau ar pilnībā atvēzētiem spārniem Putni veica Rīgas 3. starptautiskās hellēnistikas konferences ietvaros, kad luga tika izrādīta jau apjomīgākā veidolā - gan ar atslēgfragmentiem senhellēniski no paša Aristofana Putniem, gan arī mūsdienīgiem papildinājumiem - dejām un dziesmām dažādās valodās. Ludus Academicus izpildījumā Putni vienmēr ir bijuši spējīgi pielāgoties arī mūsdienu Latvijas polītiskajām un sabiedriskajām norisēm. Par to liecināja melnu tērpu izvēle putnus spēlējošajam aktieru korim trešajā iestudējumā par godu rakstu vīstokḷa Antiquitas Viva 3 atritināšanai, saskaņojot ar tolaik aktuālo Ivara Godmaṇa mudinājumu tautai būt kā pingvīniem¹. Vēl viena liecība Putnu spējai savus radošos spārnus plest arvien plašāk - spēja izrādi padarìt interaktīou, iesaistot dažādu laikmetu kultūrparādības pavisam jaunā kontekstā: līdz ar putnu solījumu sniegt putnu pienu skatītājiem tiek izkaisītas Putna piena konfektes.

Lìdz šim virtuozāko un pilnasinīgāko uzstāšanās reizi Putni ir piedzīvojuši tieši Euroclassica 2012 ietvaros Viḷnā. Pirmkārt, Putnu pamatsižets tika papildināts ar vairākām jaunām dziesmām (latviski, lietuviski, franciski, angliski, jaunhellēniski, kā arī pārskan,ojot latviešu tautasdziesmas senhellēṇu mēlē), kā arī improvizēti iesaistot tajā gan latviešu, gan hellēṇu dejas; otrkārt, saulainajos un debeszilajos Viḷnas laikapstākḷ̆os tika pieņemts ex promptu lēmums izrādīt Putnus nevis nevasarīgi tumšajās un šaurajās iekštelpās, bet brīvdabā Viḷnas Universitātes teritorijāa, kur starp daudzajiem labirintiem un

http://www.delfi.lv/news/national/quotes/godmanis-par-pingviniem.d?id=22804029 [skatīts 22.04.2013.] 


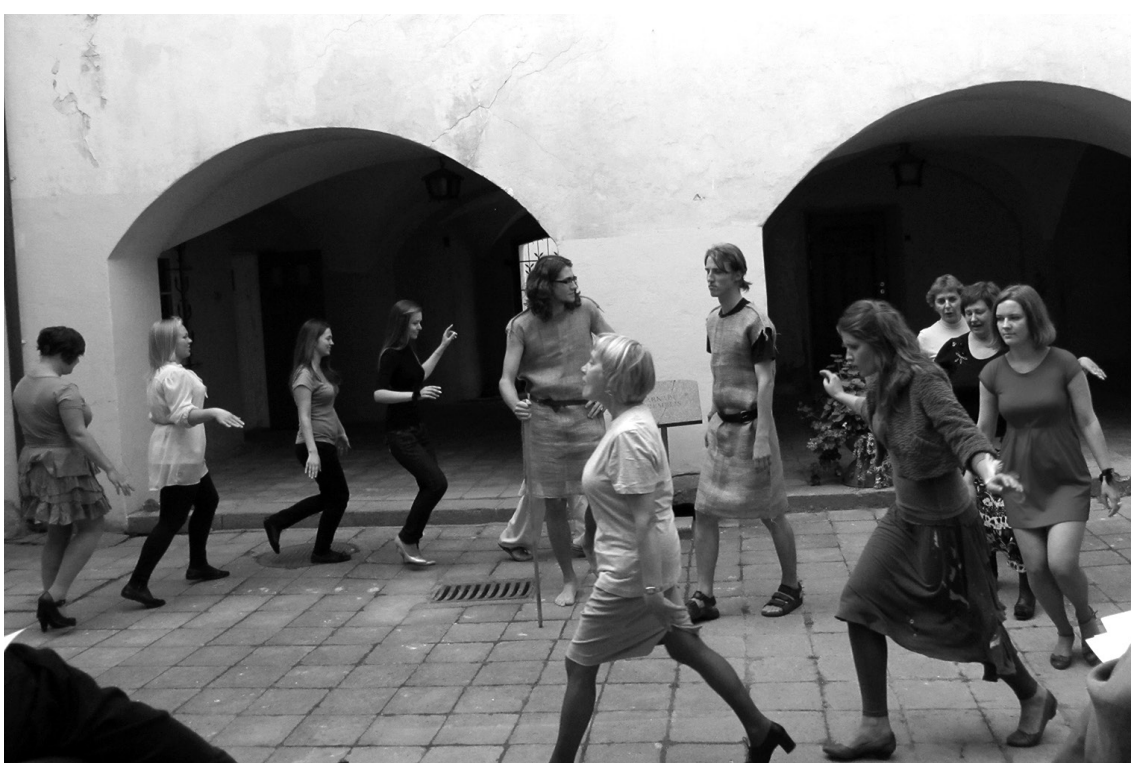

Ludus Academicus Viḷnas Universitātē 2012. gada 31. augustā starptautiskajā divu dienu konferencē Euroclassica 2012 ar Aristofana joklugas Putni fragmentiem

iekšpagalmiem tika atrasts teju vai amfiteātris, kas nodrošināja jo lielāku izrādes autentiskumu. Turklāt šoreiz izrādes skaniskā scenogrāfija tika pilnībā nodrošināta ar dzīvajiem instrumentiem - flautu un kokli (liru), kā arī, protams, nepārspējamajām putnu balsīm. Jāpiebilst, ka Ludus Academicus jau bija pieredzējis veiksmīgu uzstāšanos ārpus Latvijas - 2003. gada novembrī, kad Colloquium Balticum ietvaros Lundā, Zviedrijā, tika izrādīta Alana Aleksandra Milna Vinnija Pūka latīniskā versija (Winnie Ille Pu). Svarīgi arī pieminēt, ka viens no svarīgākajiem Ludus Academicus satversmes stūrakmeņiem ir izrāžu uzvešana tikai un vienīgi latīṇu un senhellēṇu valodā, papildinot tās ar mūsdienīgiem iestarpinājumiem labas gaumes robežās. Vēl viens nozīmīgs faktors, kas neḷauj trupā izveidoties radošajam iesīkstējumam un nodrošina pat atkārtotu lugu atšķirīgus un daudzveidīgus uzvedumus, ir mainīgais un atsaucīgais spēlējošo studentu sastāvs.

Savukārt pagaidām pēdējo (piekto) izrādīšanu Putni piedzīvoja Zinātnieku nakts 2012 izskaṇā Latvijas Universitātes Humanitāro zinātṇu fakultātes telpās. Senatnes un mūsdienu sasaisti Putnu uzveduma Ludus Academicus interpretācijā spēja saskatīt arī mūsu kolẹgi Viḷnāan, rakstot, 


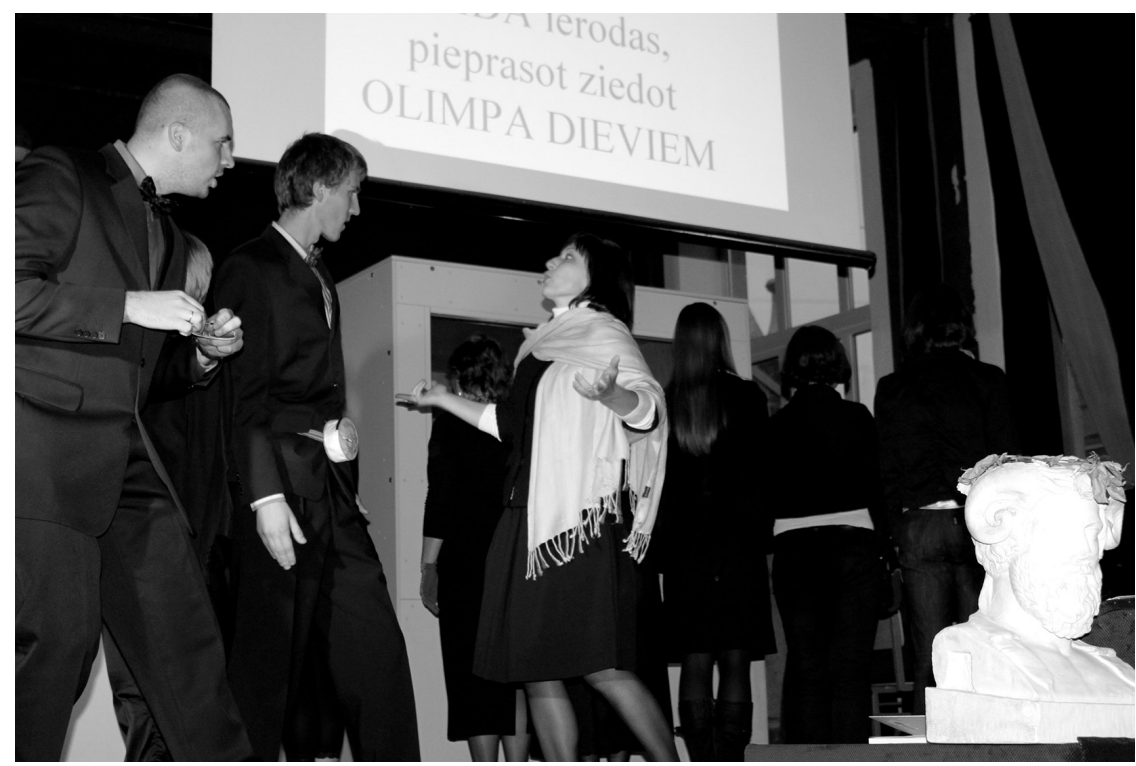

Ludus Academicus rakstu krājuma Antiquitas Viva 3 : studia classica atvēršanas svētkos

ka izrāde ir pasniegta modernā manierē, mēóginot sasaistìt izrādē attēlotos notikumus ar mūsdienām². Jāpiebilst, ka Putni ir izrādīti ne tikai Latvijas sabiedrībai, bet arī starptautiskai publikai gan Euroclassica 2012 konferencē Viḷnāâ, gan Rīgas 3. starptautiskajā hellēnistikas konferencē.

Noslēgumā jāteic, ka teātra trupas Ludus Academicus darbība un it sevišḳi ilggadējais un nepārtrauktais Putnu iestudēšanas un pāriestudēšanas cikls ir ne tikai labas ārpusakadēmiskas sadarbības paraugpiemērs studentu un pasniedzēju starpā, bet arī augstākā kaluma un raudzes uzskatāms apliecinājums, kā veiksmīgi apvienot laikmetus, lai nezustu senatnais un netiktu ignorēts laikmetīgais. $A V$ !

Mārtiņš Laizāns

2 http://naujienos.vu.lt/ivykiai/konferencijos/25505-klasikos-aktualumas-spdiai-i-kasmetinseuroclassica-konferencijos-vilniuje- [skatīts 22.04.2013.] 


\section{PĀR KALNIEM AIZDIPA KĀ STIRNAS ${ }^{1}-$ HELLĒNISTIKAS CENTRA 10 GADI}

Amerikāṇu rakstnieks Henrijs Millers savulaik, rakstot par mūsdienu grieķu kultūru, apcerē Marusi koloss norāda, ka nav ne senās, ne jaunās Griekijas, bet ir tikai viena - pasaule, kas iecerēta uz mūžiem. Romantiski patētiskais apgalvojums tomēr ir arī praktisku filoloǵisku interesi rosinošs un sasaucas ar daudzu klasisko filologu zinātkāri - paskatīties pāri antīkās pasaules robežām un uzzināt, kā hellēņu pasaule ir pastāvējusi un notikusi vēlākajos laikos, kad tai līdzās un pāri tai jau attīstījušās un uzplaukušas citas kultūras. Varētu pat teikt arī tā, ka ir tāda īpaša klasisko filologu saimes klasifikācijas iespēja - vienu grupu veido tie, kuri uzskata, ka pēc antīkās pasaules beigām hellēniskums piedzīvo norietu un izšḳišsanu un ka tāpēc vērta ir tikai senās kultūras apguve, otra grupa savukārt zinātkārojas ieraudzīt un izdzīvot tālākos līkločus.

Hellēnistikas centra darbības pamatā ir centieni caur tekstu ieraudzīt laikmetu sasaukšanos, ceḷus un veidus, kā senais līdzāspastāv un mijiedarbojas ar jauno, un to, kas īsti ir jaunlaiku Hellada. Tā kā Latvijas akadēmiskajā vidē seno Helladu iespējams iepazìt klasiskās filologijas studijās un šìm studijām Latvijā jau ir pasena stabila bāze un tradīcijas, tad saprotamā veidā Hellēnistikas centra darbs desmit gadu garumā lielākoties ir bijis vērsts uz jaungrieḳu kultūras apguvi, paturot prātā laikmetu sabalsošanās un līdzsvarošanās jautājumus.

Par Hellēnistikas centra aizsākumu Latvijas Universitātē (LU) būtu uzskatāms jau 20. gadsimta 90. gados profesores Ilzes Rūmniece izveidotais piedāvājums klasiskās filologiijas studentiem un citiem interesentiem apgūt jaungrieķu valodas kursus. Sadarbībā ar Grieķijas Kultūras ministriju izveidojās arī līdz mūsu dienām dzīva un par tradīciju kḷuvusi iespēja čaklākajiem studentiem papildināties grieḳu valodas vasaras skolās. Tad piln̄igi dabīgā veidā gadsimtu mijā radās jautājums, ko darīt tālāk ar iegūtajām valodu zināšanām, kā uzturēt un attīstìt saskarsmi ar hellēniskumu un kā to padarìt tuvu, zināmu un saprotamu plašākai publikai.

1 Raksta nosaukumā izmantota rinda no V. Grēviṇa teksta B. Sosāra dziesmai Dailes teātra izrādē Gēsta Berlings.

2 Marusi - rajons mūsdienu Atēnās, kurā 20. gadsimta vidū apmesties bija iecienījuši mākslinieki un rakstnieki, tagad tas kḷuvis par dzìvesvietu turīgiem ḷaudīm. 


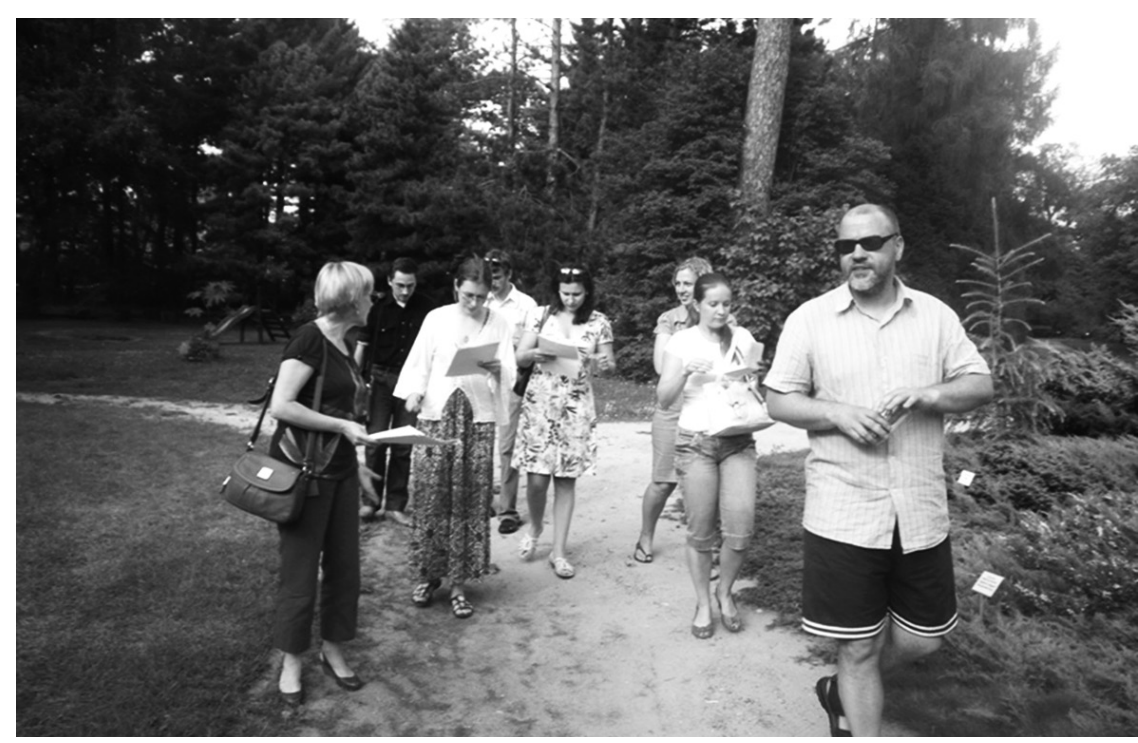

Hellēnistikas centra lasījumi Latvijas Universitātes Botāniskajā darzā

Tagad ir grūti restaurēt, kurš pirmais tieši izteica vārdus, ka nepieciešama sava pētnieciska vienība Universitātes ietvaros, bet nu jau kuplajā centra vēstures mutvārdu tradīcijā cirkulē leǵenda, ka centra izveides pamats likts jeb centrs pirmo reizi vārdā saukts 2000. gada rudenī Atēnās, satiekoties profesorei Ilzei Rūmniecei, kas bija ieradusies uz konferenci, un tolaik klasiskās filoloǵijas maǵistrantam Ojāram Lāmam, kas

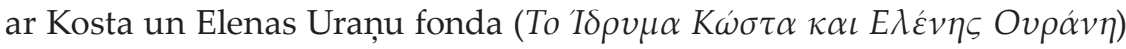
stipendijas atbalstu gada garumā Atēnu Universitātē padziḷināti apguva grieķu valodu un vienlaikus bija pievērsies Jorga Sefera daiḷrades pētniecībai. Peripatētiski sarunājoties Universitātes galvenās ēkas kolonādē, izkristalizējās plāns turpmākajam hellēniskajam darbam LU. Nedaudz vēlāk Latvijā tika sapulcēti sengrieḳu lietas studējušie un pa vasaras skolām un citiem ceḷiem jaungrieḳu lietās iejutušies Daiga Lapāne un Dens Dimiņš un iezīmēta centra darbības perspektīva, kas tolaik un joprojām balstās uz trim vaḷiem: jaungrieḳu literatūra; visu hellēniskumu aptverošas pētnieciskas konferences; zinātniskas publikācijas. Visās iecerētajās jomās ir gūti ievērojami panākumi, daudzas idejas nākušas klāt, dažas vēl nav spēts realizēt, bet darbīgā gaisotne centrā, padarītais un iestrādes ḷauj ar paḷāvību skatīties nākotnē - tā sola daudz jaunumu un labumu. 


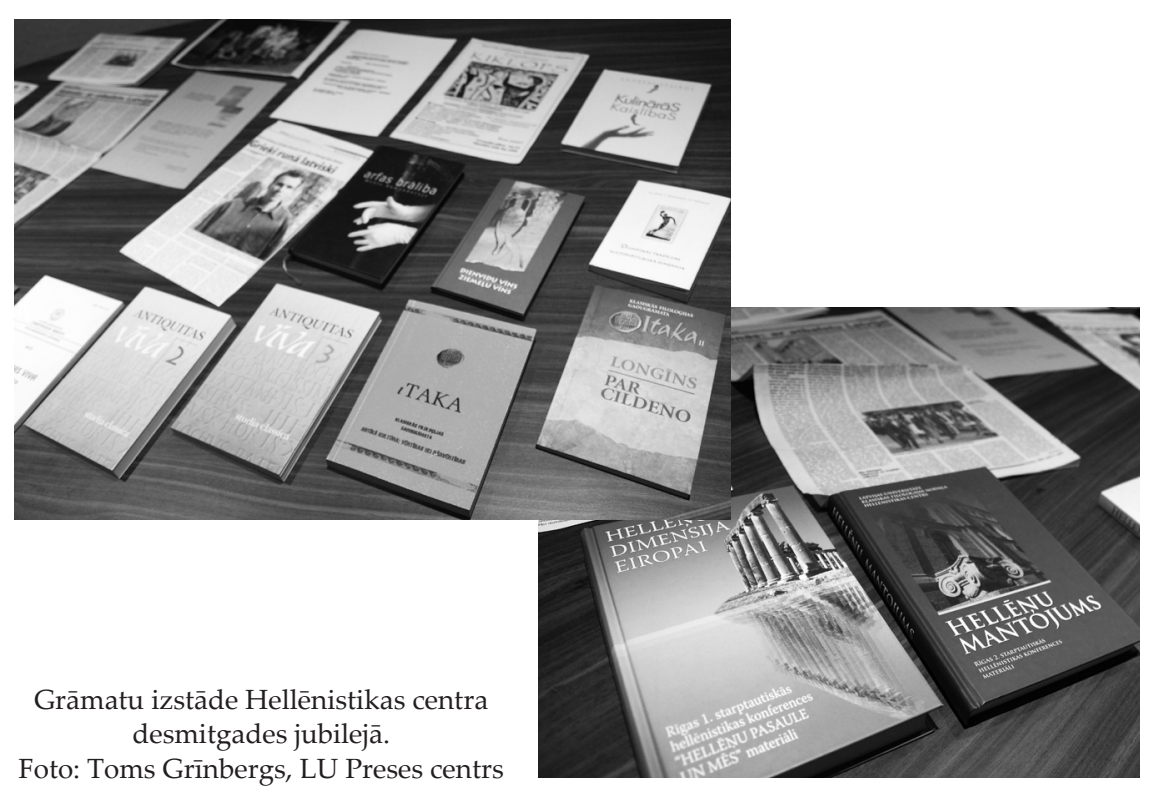

Grieḳu literatūras apguves jomā visus šos gadus interesentiem ar pietiekamām grieķu valodas zināšanām ir bijusi iespēja piedalīties t. s. grieķu lasijjumos, kuros ik sezonu uzmanības lokā bijis kāds jaungrieḳu literatūras klasiḳis vai kāds jaunlaiku autors - iepazīta Konstantina Kavafja

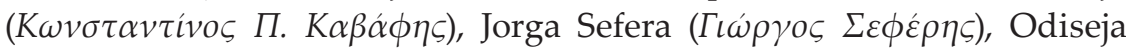

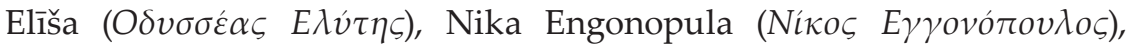

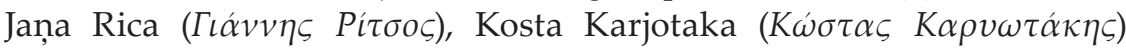

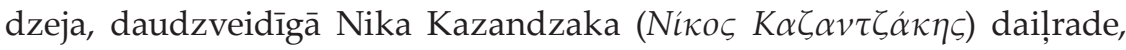
Aleksandra Papadiamanža ( $A \lambda \varepsilon ́ \xi \alpha v \delta \rho \circ \varsigma \Pi \alpha \pi \alpha \delta \iota \alpha \mu \alpha v \tau \eta \zeta)$, Lili Zografu

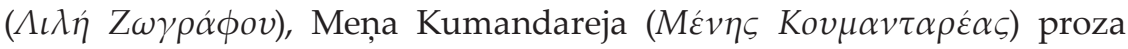
un vēl citu autoru daiḷrade. Iepazīti arī pavisam jaunie 21. gadsimta

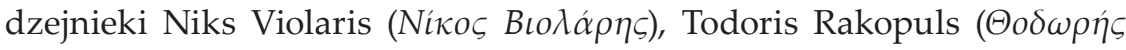

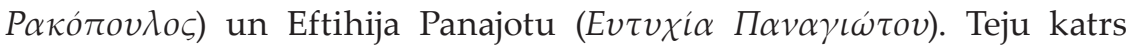
tekstu lasījumu cēliens ir noslēdzies ar publiskiem literāriem sarīkojumiem, atsevišķi dzejas tulkojumi publicēti presē. Plašāku tekstu tulkojumus lasītājiem ir piedāvājuši Dens Dimiņš, Iveta Skrastiṇa (Ivanova), Daiga Lapāne.

Otra centra darbības līnija ir starptautiskas hellēniskā mantojuma studiju konferences, kas ieguvušas olimpisku norises ciklu un jau trīs reizes Latvijā pulcējušas plašu pasaules pētnieku sabiedrību, 


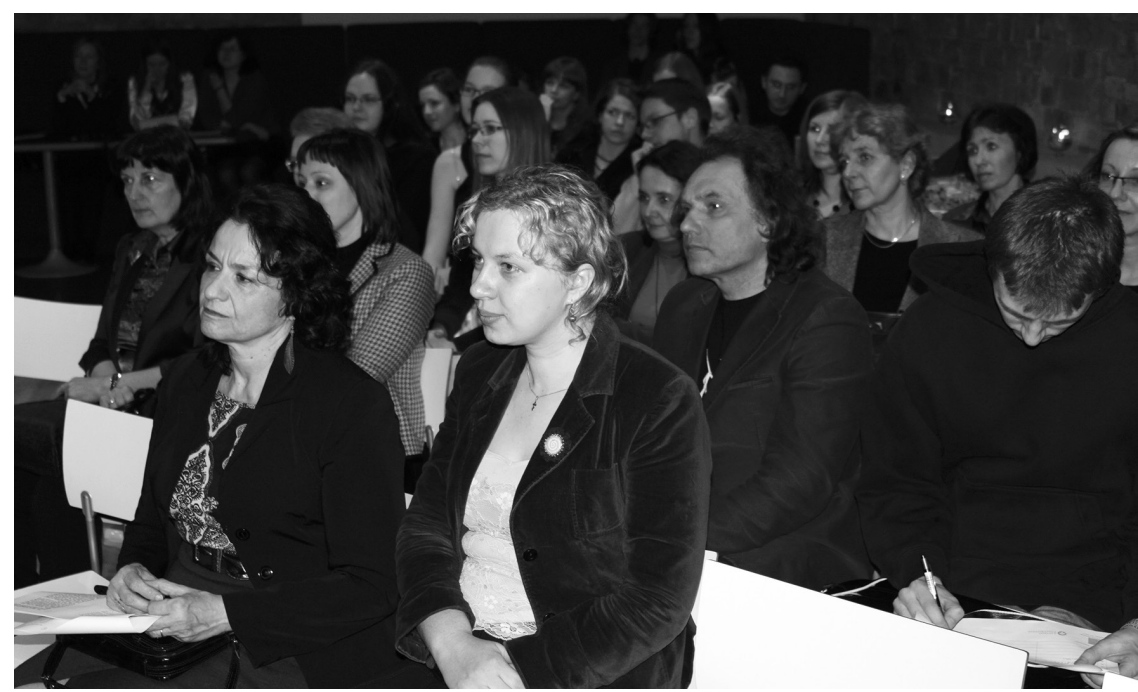

Semināra Hellenoterapija dalībnieki

padarot Rīgu par nozīmīgu vietu hellēnistiskas pētījumu starptautiskajā ǵeogrāfijā.

Starptautisko hellēnistiskas konferenču atbalsis iezīmē Hellēnistikas centra veidoto zinātnisko rakstu sērija, kurā iznākuši trīs krājumi, no kuriem divi ir bilingvāli, bet viens - angḷu valodā.

Lìdztekus minētajām regulārajām norisēm Hellēnistikas centrs ir centies pievērst sabiedrības uzmanību gan nozīmīgām jubilejām, piemēram, Maratonas kaujas 2500. gadadienai, gan atsevišķiem grieḳu kultūras fenomeniem, piemēram, rebetikas mūzikai, gan citiem ar Hellēnistiku tiešāk vai pastarpinātāk saistītiem notikumiem, piemēram, Olimpiādes norisei Atēnās, kam par godu tika sagatavota un izdota olimpiskajai tradīcijai veltīta grāmata.

Arī sākoties otrajai centra darbības desmitgadei, aizsāktu darbu un ieceru ir gana daudz, centra darbinieku rindas ir papildinājuši jauni sparīgi hellēnisti - Brigita Kukjalko, Mārtiņš Laizāns, Līva Muižniece un citi, kuru pētnieciskās un radošās ieceres saistās gan ar seno, gan bizantisko, gan jaunlaiku hellēniskumu, tā ka centra darbība turpinās daudzveidīga un krāsaina.

Centra pastāvēšanas desmitgades veiksmes un panākumi nebūtu iespējami bez draudzīga atbalsta, ko sniegusi LU, Latvijas Kultūras akadēmija, Latvijas Kultūrkapitāla fonds, Grieḳijas Kultūras ministrija, 


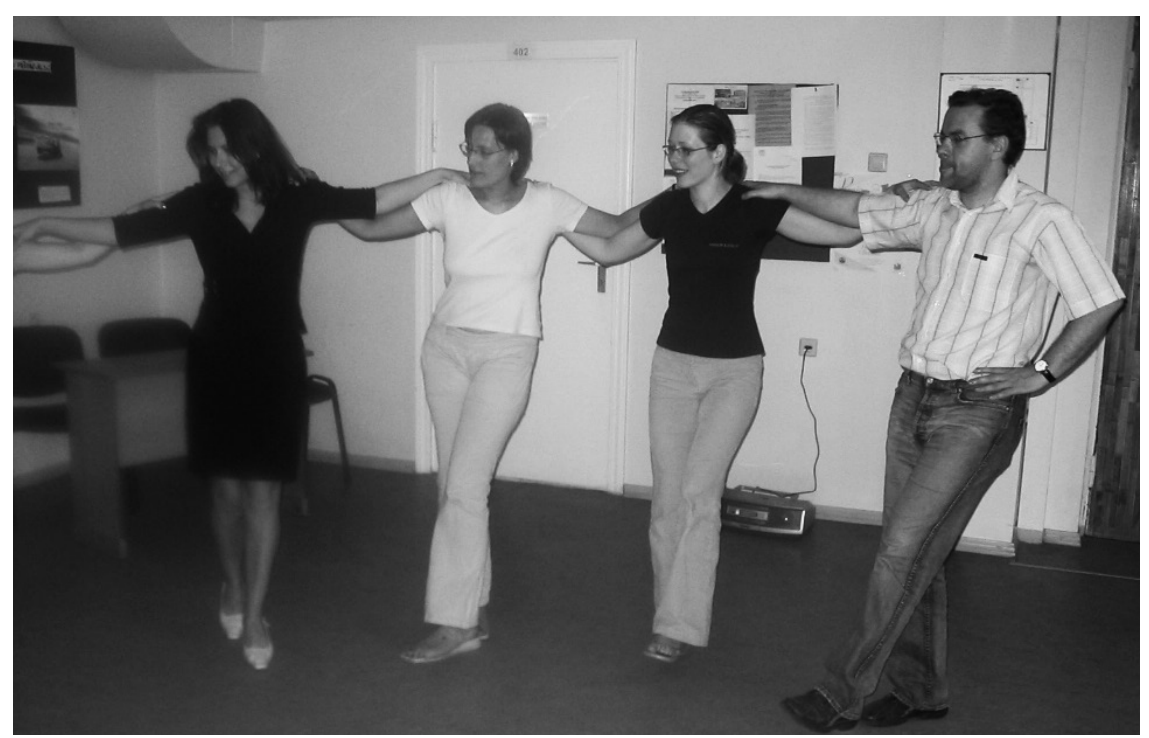

Grieḳu tautas deju apguve Hellēnistikas centra lasījumos

Grieḳijas Izglìtības ministrija, Grieḳijas Republikas vēstniecība Latvijā, kā arī Starptautiskā Nika Kazandzaka biedrība.

Centra pastāvēšanas gadi būtu bijuši daudz bālāki, ja ar savām idejām, personisku atbalstu un gatavību līdzdarboties centra pasākumus nebūtu atbalstījuši dažādu jomu speciālisti, kurus gribētos nosaukt par Hellēnistikas centra draugiem. Pirmais starp tiem minams Berlīnes Brīvās universitātes profesors Konstantins Dimadis - agrīno jaunhellēniskās attīstības norišu Latvijā lielais atbalstītājs, aizraujošā un iedvesmojošā kādreizējā Griekijas Kultūras ministrijas Ārējo sakaru departamenta direktore Alkiste Sulojani, kura ne reizi vien viesojusies Latvijā un ir apmeklējusi vairākus Hellēnistiskas centra pasākumus, kādreizējā Griekijas Republikas ārkārtējā un pilnvarotā vēstniece Latvijā Hrisante Panajotopulu, kā arī grieḳu kultūrā dziḷi ieinteresētie tautieši - Kultūras akadēmijas profesori Raimonds Briedis, Valda Čakare, Zane Šilina un Latvijas Universitātes profesori Valdis Muktupāvels un Harijs Tumans. Vislielākais gandarījums un prieks ir par to, ka Hellēnistikas centra darbi ir uzrunājuši studentus un viṇi allaž kuplā skaitā ir līdzdarbojušies centra norisēs. 


\section{PLATONA AKADĒMIJA: CEḶĀ UZ ZINĀŠANĀM}

Latvijas Universitātes (LU) Humanitāro zinātṇu fakultātes (HZF) Klasiskās filologijas un antropologijas studiju nodaḷas Klasiskās filologiijas katedras lektore Brigita Kukjalko 2012. gada vasarā apmeklēja filozofijai un tās saiknei ar visdažādākajām mūsdienu zinātnes jomām veltītu vasaras skolu Platona akadēmija, kas norisinājās Atēnās, Griekijāà.

2012. gada (pirmajā) Platona akadēmijā piedalījās 20 visdažādāko zinātṇu pārstāvji (doktora grāda kandidāti, zinātṇu doktori un pētnieki) no 16 valstīm (Argentīnas, Armēnijas, Čehijas, Grieḳijas, Horvātijas, Itālijas, Izraēlas, Melnkalnes, Kipras, Latvijas, Peru, Portugāles, Serbijas, Slovākijas, Spānijas un Ukrainas). Dalībnieki pārstāvēja filozofijas, fizikas (t. sk. biofizikas), politikas zinātnes, informācijas tehnologiiju, dabaszinātṇu (medicīna, biolog̣ija), psiholog̣ijas, tiesību zinātṇu u. c. jomas. Klasisko filolog̣iju vasaras skolā pārstāvēja LU klasiskā filologe, seno valodu speciāliste B. Kukjalko. Galvenais priekšnoteikums dalībai šajā vasaras skolā bija - dalībnieka zinātniskajām interesēm jābūt saistītām ar zinātnes, zināšanu filozofiju, piemēram, kādas zinātnes jomas pētījumu metožu, pamatprincipu un citu aspektu pētǐšanu.

Vasaras skolas diskusiju kontekstā, kur uzmanība tika veltīta zinātnes filozofijai un reprezentācijai (t. sk. arī zinātnes valodai), noderīgas bija atziņas, ko B. Kukjalko guvusi doktorantūras studiju laikā veiktajā pētījumā par mūsdienu humanitāro zinātṇu vidē funkcionējošās zinātnes valodas pirmsākumiem sengrieḳu filoloǵiskajos tekstos (promocijas darbs Sengriek, filologisko tekstu valoda, 2011).

Vasaras skolas programma sastāvēja no 16 lekcijām un 6 semināriem. Lekcijas lasīja un seminārus vadīja mācībspēki no Atēnu Akadēmijas, Atēnu Universitātes, Atēnu Tēlotājmākslas skolas, Bristoles Universitātes, Kalifornijas Universitātes, Krētas Universitātes, Oksfordas Universitātes, Patru Universitātes, Pomonas koledžas Kalifornijā un Tesalonīkes Aristoteḷa universitātes. Vienu no semināriem par stāsta radīšanas aspektiem vadija rakstnieks Apostols Doksiadis (Apostolos Doxiadis), grāmatas Logicomix autors (Logikomikss - pasaulslavens bestsellers, romāns, kura vēstītājs filozofs Bertrands Rasels (Bertrand Russell) stāsta par patiesības meklējumiem). Visas nodarbības notika angḷu valodā. Lekciju tematika aptvēra visdažādākos zinātniskās domas pētīšanas aspektus, piemēram: Eksperiments zin̄̄tnē; Apvienojot sajūtas: sinestēze filozofijā, zinātnē un mākslā; Atveidojums mākslā un zinātnē; Ētika zinātnē: zinātniskās 


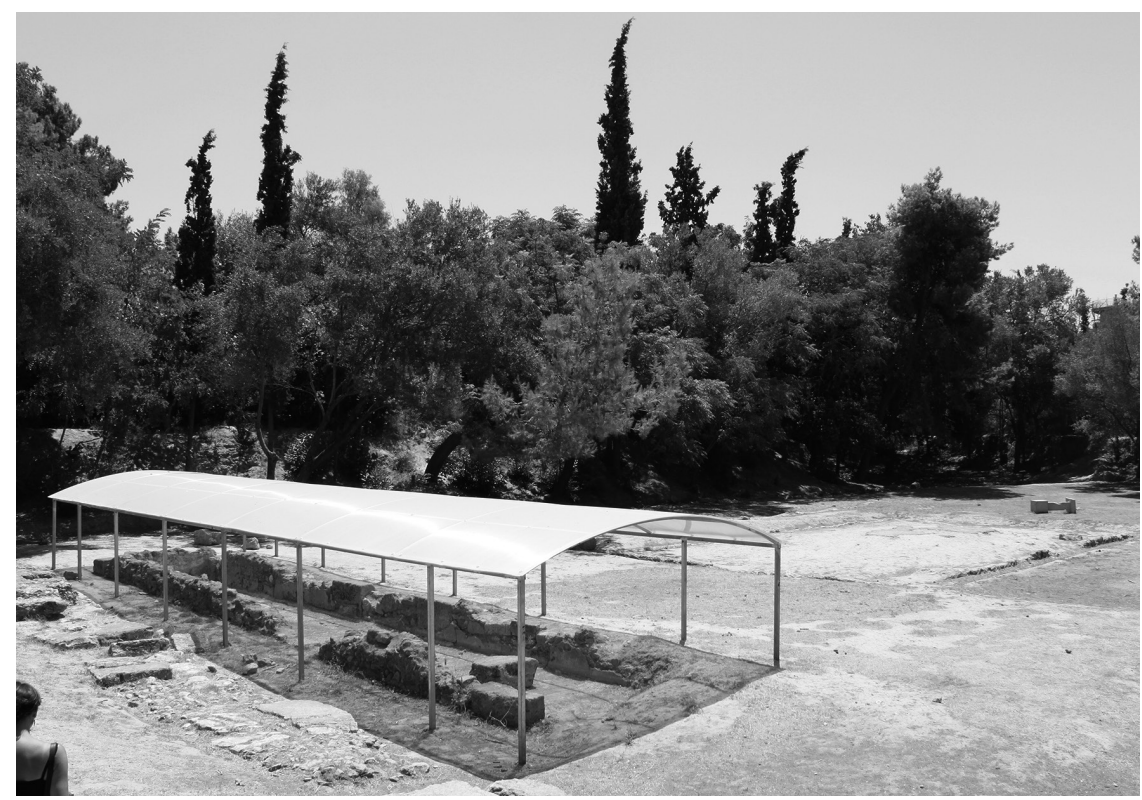

Šajā vietā - pavisam netālu no Atēnu centra - 4. gs. p. m. ē. sākumā tika dibināts un vairākus gadsimtus (līidz m. è. 6. gs.) pastāvēja viens no galvenajiem antīkās pasaules izglītošanās centriem - Platona akadēmija

atbildības formas; Bioētika: jēdziena eksplikācija, principi, metodes, problēma; Griek̦u brīnums; Labestības acīmredzamības nozìme; Grieķu zinātnes pirmsākumi; Zinātne un patiesība u. c. Semināros tika diskutēts par izaicinājumiem zinātnē un ar tiem saistītām morāles dilemmām (eitanāzija, klonēšana), stāsta radīšanas aspektiem, zinātnes jautājumu un rezultātu atainošanu. Viens no semināriem bija veltīts jautājumam - kāpēc pētīi dabu? Atbildes tika meklētas sengrieķu filozofu domās par dabas pētīšanas mērḳiem. Visu lekciju un semināru galvenā raksturiezīme bija jautājumi - to bija daudz vairāk nekā atbilžu. Tas, protams, domu risināšanas un attīstī̌sanas aspektā vērtējams l,oti pozitīvi, bet nenoliedzami bija arī diezgan nogurdinoši.

Par personiski - gan individuālajai, gan arī profesionālajai izaugsmei - noderīgākajām B. Kukjalko uzskata Bristoles Universitātes profesora Aleksandra Bērda (Alexander Bird) lekciju Zināšanu mainīgā daba, Atēnu

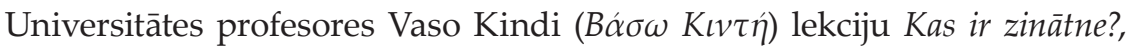
Oksfordas Universitātes profesora Džona Haimana (John Hyman) lekciju Griek,u brīnums, kā arī rakstnieka A. Doksiaža semināru Logikomikss. 


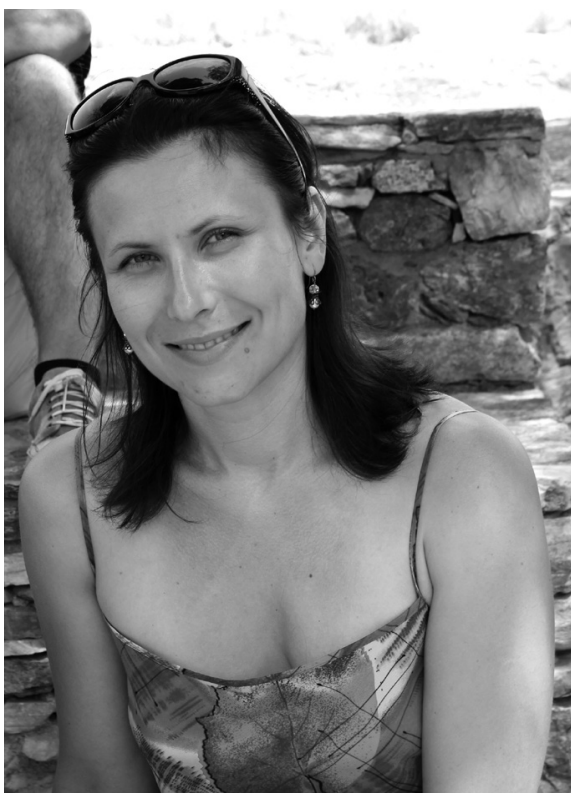

Platona akadēmijas 2012 dalībniece Latvijas

Universitātes Humanitāro zinātṇu

fakultātes lektore

Dr. Brigita Kukjalko

A. Bērda lekcijā Zināšanu mainīgā daba uzmanība tika pievērsta trīs ievērojamāko sengrieķu pētnieku - Aristoteḷa (fizikas jomā), Ptolemaja (astronomijas jomā) un Galēna (medicīnas jomā) - pausto domu diahronai izvērtēšanai, atmešanai, pārn,emšanai un attīstīšanai.

V. Kindi lekcijā Kas ir zinātne? klausītāji tika rosināti domāt, vai virkne jomu, kuras ierasti saucam par zinātniskām, šādu apzīmējumu tiešām ir pelnījušas (piemēram, medicīna, tieslietas, vēsture, ekonomika u. c.)? Kādu jēdzienisko saturu mūsdienās īsti ietver vārdi zināšanas un zinātne?

Lekcijā Grieku brīnums estētikas profesors Dž. Haimans centās ieskicēt sengrieḳu mākslas, piemēram, skulptūras, attīstību, vienlaikus mēǵinot atbildēt uz jautājumiem, kāpēc šis sengrieḳu mākslas brīnums tomēr sākās tik salīdzinoši vēlu un kas bija tie faktori, kas sekmēja tā attīstību (piemēram, materiālu atklāšana: marmors, bronza; sociālie faktori: izglītošanās; drāma: emociju, izjūtu atainošana u. c.). Dž. Haimans uzsvēra, ka sengrieķu māksla nav uzskatāma, piemēram, par pārāku nekā seno ēǵiptiešu māksla, tā vienkārši atklāj tā brīža grieḳu pasaules uztveri, kā arī tā brīža grieķu spēju atainot pasauli.

A. Doksiadis seminārā Logikomikss norādīja, ka jebkura pētījuma pamatā ir stāsts. Arī stāsts ir zinātnes jomas veidotājs. Semināra gaitā tika 


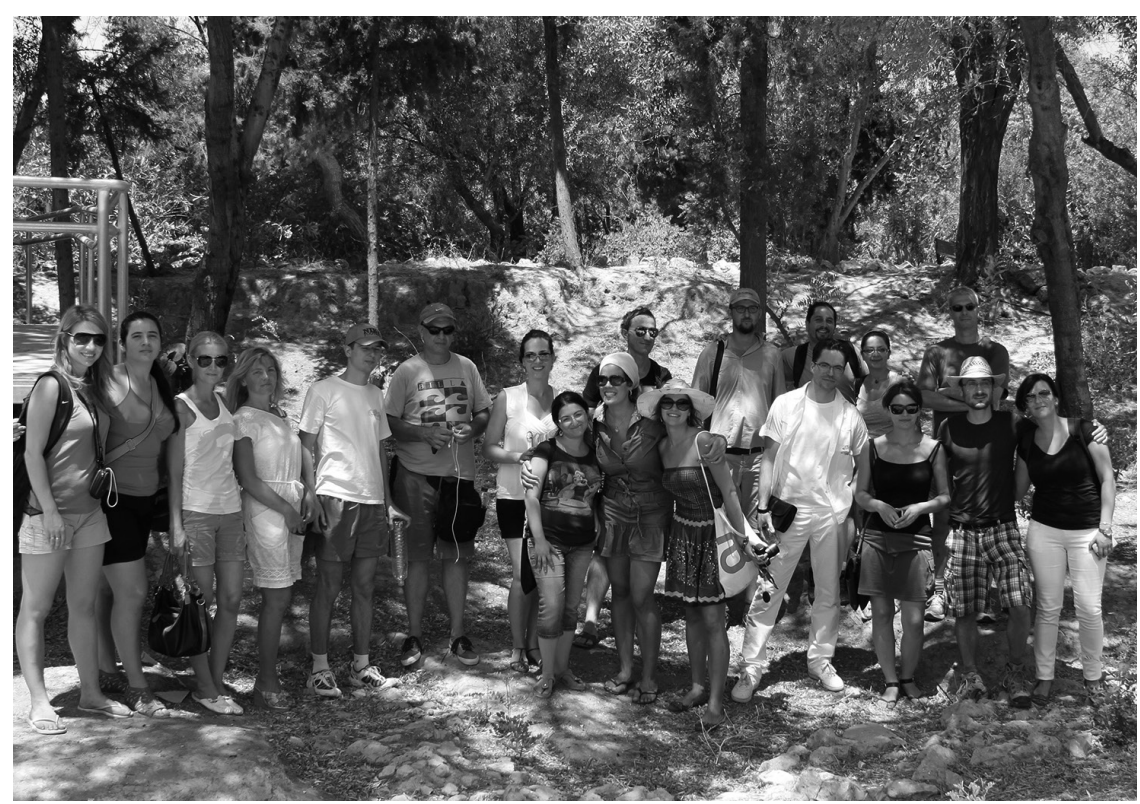

2012. gada Platona akadēmijā piedalījās 20 visdažādāko zinātṇu pārstāvji no 16 valstīm

analizēti stāsta veidošanas aspekti - kas uzskatāms par stāsta sākumu, kulmināciju, atrisinājumu? Cik daudzslāṇaina ir katra no šìm daḷām? Katram semināra dalībniekam, vadoties pēc A. Doksiaža sniegtajām stāsta veidošanas vadlīnijām un balstoties uz reāliem notikumiem, bija jāsacer un jāizstāsta stāsts, kas būtu saistìts ar stāstītāja individuālo pētỉjumu lauku un kuru pārējie nezinātu. Jāpiebilst, ka A. Doksiaža vadītā semināra laikā gūtās zināšanas un atziṇas lektore B. Kukjalko izmantoja antīkās drāmas semināros 2012. gada rudens semestrī, kopā ar klasiskās filoloǵijas 3. kursa studentiem analizējot traǵēdiju un komēdiju tekstus.

Neapšaubāmi daudz vērtīgu zināšanu un atziṇu tika gūts arī visās pārējās Platona akadēmijas nodarbībās. Jānorāda, ka mācību programma bija l,oti blīva, mācības notika katru darbdienu no 9.30 līdz 14.00 un no 18.00 līdz 20.00. Gan pirms vasaras skolas, gan arī tās laikā (brīvajā laikā) bija jāizpilda dažādi mājasdarbi - jālasa, jāskatās video fragmenti tiešsaistē, jāvērtē. Šādu darba stilu un prasībās pat vēl stingrāku Platona akadēmijas organizatori iecerējuši arī 2013. un 2014. gada vasaras skolās.

Runājot par vasaras skolas praktiskajiem aspektiem, jāpiebilst, ka tās dalībniekiem tiek nodrošināta dzīvošana viesnīcā Atēnu centrā, 
ēdināšana, transports uz nodarbību vietu un atpakaḷ uz viesnīcu, ekskursijas Atēnās un Atikā nedēḷas nogalēs. Vasaras skola nemaksāja vien par dalībnieku nokḷūšanu Atēnās un atgriešanos mītnes zemē.

Bagātīgā mācību satura, kā arī intensīvās slodzes dēḷ Platona akadēmijas studenta sajūtas noteikti varētu salīdzināt ar tām, kādas varētu būt bijušas īstās Platona akadēmijas studentiem Senajā Grieḳijā pirms apmēram 2500 gadiem - es zinu, ka neko nezinu..., un tomēr klausos, rakstu, lasu un gribu zināt vēl un vēl...

Brigita Kukjalko

\section{DIALOGI ATGRIEŽAS ATĒNĀS}

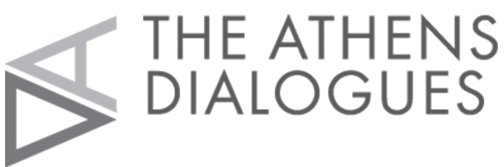

Mūsdienu klasiskajiem filologiem, iespējams, būtiskākais uzdevums ir līdztekus tradicionālajiem pētniecības lokiem skatīt antīkās vērtības mūslaiku prizmā, vērtējot un pārliecinoši parādot to iespējas transformēties, saglabājot satura, formas, metožu, principu būtību.

Viens no interesantiem piemēriem ir slavenā Onasis fonda piedāvājums jaunuzceltajā Izglītības un mākslu namā $(\Sigma \tau \dot{\varepsilon} \gamma \eta \Gamma \rho \alpha \mu \mu \alpha \dot{\tau} \omega \nu \kappa \alpha \iota$

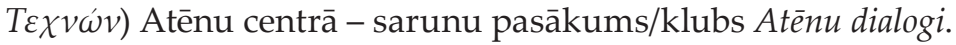

Šì informatīvā raksta autorei bija iespēja piedalīties pašā pirmajā Atēnu sarunu raundā 2010. gada novembrī, uz kuru kā goda viesi (bez dalības maksas) tika uzaicināti Onasis fonda stipendiāti (kuru pulkā ir arī autore). Tādēḷ var runāt par klātienes iespaidiem.

Pirmkārt, iespaidīgs bija pats fakts un laiks: grieḳi Atēnās aicināja uz sarunām - gluži kā klasiskajos laikos 5. gadsimtā pirms mūsu ēras Sokrata garā - atzītākos pasaules zinātniekus un to klausītājus - plašu publiku (centra galvenā zāle ir vismaz Rīgas kongresu nama zāles lielumā, un tā bija pilna). Norises laiks: pēc 2009. gada nogales ar daudzajām ziṇām par teju Paneiropas krīzi 2010. gads nāca kā risinājumu (kḷūmju iemeslu?) apcerēšanas posms. Atēnu dialogi piedāvāja sarunas par grieķu klasiskajam vērtībām kā tām, pie kuru apzināšanas - jau mūslaiku aktualitāšu kontekstā - ir vērts atgriezties. 
Sākotnēji tika piedāvāti seši sarunu tematiskie loki, kuri saglabāti arī turpmākajos raundos, jo dialogi turpinās ar regularitāti 1-3 sarunas gadā:
1. Identitāte un atškirīiba
4. Demokrātija un valsts
2. Vēstījumi un vēsture
5. Zinātne un ētika
3. Logoss un māksla
6. Dzīves kvalitāte

Pirmo dialogu organizētāji bija prominentas izglītības un pētniecības iestādes: Atēnu Akadēmija, Austrijas Zinātṇu akadēmija, Franču institūts, Vācijas Arheolog̣ijas institūts, Hārvarda Universitātes Hellēnuu studiju centrs, Oksfordas un Stenforda Universitāte.

Lai apspriestu grieķu kultūras sasniegumu un ieguvumu lomu mūsdienu pasaulē, piedāvājot savu redzējumu un argumentus, par minētajiem tēmu lokiem tika aicināti izteikties ne tikai minēto institūciju izcilnieki mācībspēki un zinātnieki, bet sarunās varēja piedalīties visi klātesošie (jebkurš klausītājs), iesniedzot jautājumu vai piedāvājot savu repliku. Tika nodrošināta arī tiešsaiste un jautājumu iesniegšana e-formā, kas, protams, deva iespēju teju 50000 sekotāju piedalīties Atēnu sarunās. Interese bija patiešām liela, un visdrīzāk to rosināja šis krīzes laiks, kad cilvēks arvien meklē stabilitātes un pārbaudītu vērtìbu atbalstu. Eiropas hellēniskā klasika tāda bija un turpina sevi piedāvāt kā „balstu” arī mūsdienās.

Mūslaikos apsveicams piedāvājums šajā pirmajā dialogu sērijā bija humanitārās un eksaktās jeb dabaszinātṇu jomas speciālistu kopāsanākšana, gluži kā Aristoteḷa laikos, kad zinīgs un pētniecisks prāts spēja aptvert tās abas.

Atmosfēra klātienē bija lieliska, jo sarunas nerimās arī kafijas pauzēs; veidojās jaunas pazišanās un interesanti kopdarbu priekšlikumi. Rosinātājs noteikti bija hellēnisko mūžīgo vērtību gars, to atgādne un kopīga apzināšanās. Var teikt, ka daudzu tēmu izrisinājums sniedza pat zināmu katarsi.

Atēnu dialogu tēmas laika gaitā sašaurinās un kḷūst konkrētākas, tādēḷ vēl jo vērtīgāki bija pirmie dialogi 2010. gadā, kuri piedāvāja aptvert hellēnisko domu/veikumu visā plašumā kā zināmu paraugu jeb iedvesmu mūsdienu domām, pētījumiem, darbiem.

Dialogi Atēnās ir atgriezušies jaunā, mūslaiku kvalitātē (www. athensdialogues.org). 


\section{MARATONAI - 2500 \\ SKRIENU, SKRIENU VEEL...}

...Man vēl jāpaspēj $j^{1} \ldots$ Steigā skrien un aizskrien mūsu ikdiena, jāsteidz laikā padarìt ieplānotie darāmie un arvien nepadarāmie darbi. Mēs sasniedzam noteiktus mērķus, iezīmējot kādus atskaites punktus, atkal un atkal no jauna startējam un finišèjam un atkal ejam, dodamies un skrienam tālāk. Bet mums ir dota iespēja laika ritējumā ne tikai būt tagad, to mērìt, skaitìt un plānot, bet arī - aizceḷot tālajos pagātnes gadsimtos un pat gadu tūkstošos, piemēram, lasot un pētot, tulkojot vēsturiskus tekstus. Un mums ir dota iespēja laika ritējumu svinēt!

Tā 2010. gada nogalē - 14. decembrī - Latvijas Universitātes (LU) Vēstures muzeja zālē Raiṇa bulvārī 19 bija šāda unikāla iespēja - būt klāt laikaptverošas, apaḷas jubilejas svinībās, kad Klasiskās filologijas katedra un Hellēnistikas centrs aicināja būt klāt ikvienu interesentu Maratonas uzvaras 2500 gadu jubilejas atzīmēšanas pasākumā, kas vienlaikus bija simbolisks maratons - literārs un reāls. Proti, tas veidojās no LU docētāju, studentu un Grieḳijas vēstniecības pārstāvju lasījumiem (oriǵinālā un tulkojumā), mērḳtiecīgi izraugoties citātus, kuros ietverts vai nu skriešanas, vai ceḷa motīvs. Ikvienā priekšnesumā tika iekḷauts arī reālas skriešanas elements vai nu kombinācijā ar lēnāku teciṇu uz vietas, vai lasījuma noslēgumā noskrietā goda aplī, vai arī spārnotu sandeḷu improvizācijā. Izskanēja fragmenti gan no Homēra epiem, gan tragēèiju autoru Aishila un Euripīda, komediogrāfa Aritofana darbiem, piemēram, daži citāti:

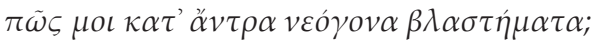

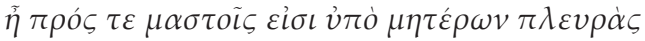

$\tau \rho \dot{\varepsilon} \chi o v \sigma \iota^{2}$.

Kā klājas alās maniem jaundzimušiem jēriņiem?

vai ir pie pupa savām mātēm un vin̄àm blakus

skrien? (Eur. Cycl., 206-208)

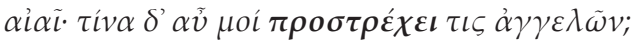

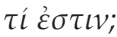

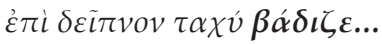

1 Raksta nosaukumā un ievadā izmantota rinda no M. Freimaṇa teksta L. Reinika dziesmai Es skrienu.

2 Šeit un citviet raksta autores izcēlumi.

CLXIX 


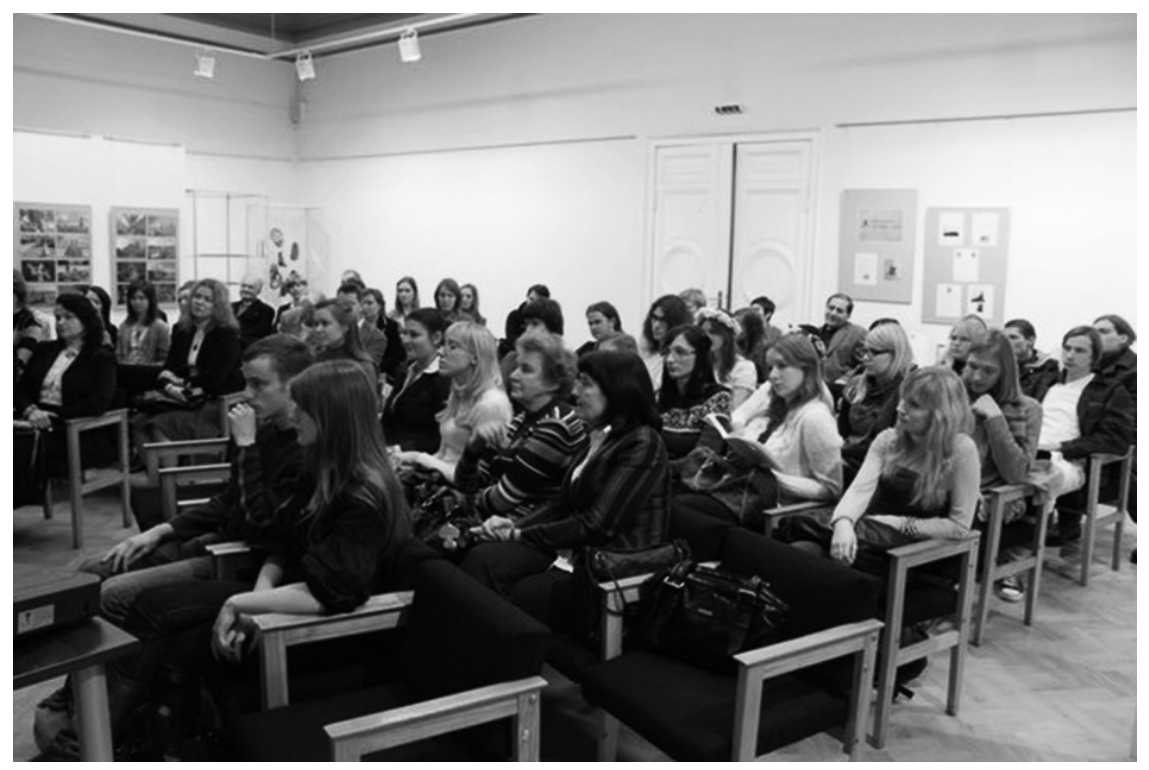

Maratonas 2500. jubilejas svinētāji LU Vēstures muzeja telpās

ai, ai, vai šurp skrien vēl kāds ziṇnesis?

kas noticis?

$n \bar{a} c \bar{a}$ tri šurp uz mielastu! (Aristoph. Acharn., 1084-1086)

Tika ietverti fragmenti arī no antīkās senatnes ārstēšanas mākslas pamatlicēja Hipokrāta, sengrieḳu oratora un rētora Isokrata, filosofu Platona un Aristotela darbiem:

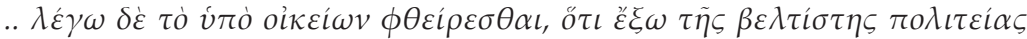

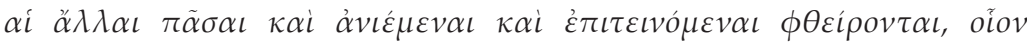

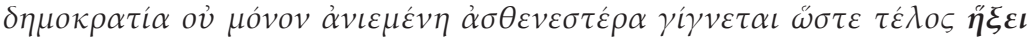

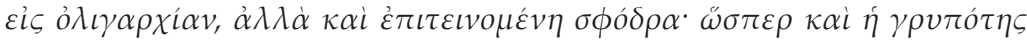

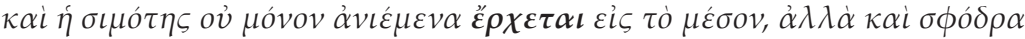

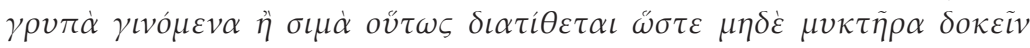
EIval.

.. Es runāju par to, ka valsts iekārtu, izņemot vislabāko, iznīcina tai raksturīgais. Tās visas iznīcina pārmēru val̄ina vai stingrība. Piemēram, tautvaldība ne vien pārmēru vaḹga, bet arī pārmēru stingra kḷūst nespēcīgāka, un galu galā nonāks pie dažvaldības. Tāpat lìks deguns vai strups deguns, raksturīgajam samazinoties, nonāk pie vidusmēra, bet, kḷūstot pārmēru līks vai 
strups, tas tā izmainās, ka neškiet esam deguns. (Arist. Rhet., 1360a. 23-30, tulk. Brigita Kukjalko)

"Skrēja" arī 19. un 20. gs. dzejnieki - Soloms, Elitis, Seferis, Kiki Dimula, Niks Engonopuls, Janis Rics un Aleks Sakelaris:

\author{
$\Upsilon \pi \circ \mu \nu v \dot{~}$

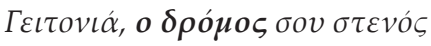

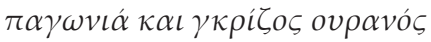 \\ $\mu \alpha \hat{v} \rho \eta \zeta \omega \eta \dot{~}$ \\ $\beta \rho \alpha \dot{\delta} v \pi \rho \omega i$ \\ $\gamma \iota \alpha \sigma v v \tau \rho o \phi \iota \alpha ́$

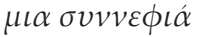

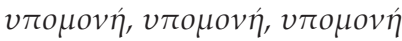

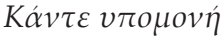

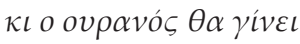

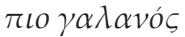

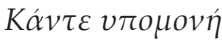 \\ $\mu \iota \alpha \lambda \varepsilon \mu o v \iota \alpha ́$

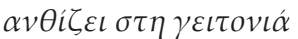

\section{Pacietība}

Mana pagalma celiņi šauriņi

Stīos stingums un pelēki debeši

Tā pati dzìve tik melnā

ik rìtā un vakarā

Viens vienīgais drauğelis

tas baltais mākulis

pacietību, pacietību, pacietìbu

Pacieties!

Un kḷus zilāki

debeši

Pacieties!

Ieskaties citronkokā,

kas zied tepat, tavā pagalmā

(Aleks Sakellaris, Pacietība, atdz. Iveta Skrastiņa)

Ieskicējot Maratonas kaujas (490. g. pr. Kr.) vēsturisko notikumu fonu, asoc. prof. Harijs Tumans uzsvēra, ka grieķu-persiešu karu laikā Maratonas kauja bija viena no izšḳirošajām (līdztekus vēlāk legendārajām kaujām pie Termopilām, Salamīnas un Platajām), jo tā bija kulminācija pirmajam nozīmīgajam Persijas impērijas valdnieka Dārija I mēǵinājumam pievienot impērijai Grieḳijas zemes, un šis mēǵinājums par spīti milzīgam pārspēkam beidzās ar grieḳu uzvaru, zaudējot vien 192 vīrus, bet persiešu pusē kritušo skaits sasniedzis 6400 (dažādos vēstures avotos minēts dažāds persiešu karotāju skaits, kas svārstās no 20000 līdz 60 000, pārsvarā tie bija loka šāvēji un jātnieki, bet grieḳu karotāju - pārsvarā hoplītu - skaits bijis trīs reizes mazāks). Paziṇot par spožo un tik nozīmīgo uzvaru atēnieši esot sūtījuši uz Spartu skrējēju (vai nu tas bijis Filipīds vai Feidipīds, daži pētnieki vispār apšauba šo faktu), kurš spēku izsīkumā, izdvešot „mēs esam uzvarējuši!!

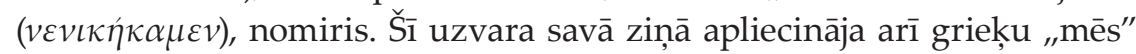
jeb demokrātijas uzvaru pār persiešu „es” jeb „autarkiju”, un tas bija drosmīgs grieḳu óxı (nē), kas kḷuva par pašapziņas un lepnuma simbolu. 
Spartieši sengrieḳu vāzes zīmējumā

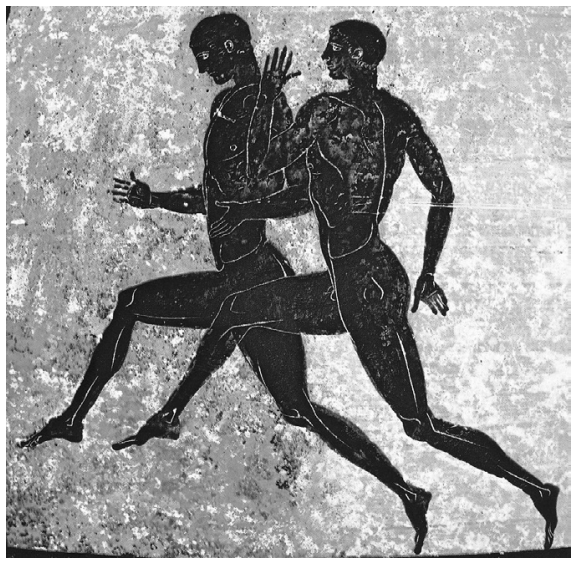

Klātesošos uzrunāja arī Griekijas vēstniece Latvijā Hrisante Panajotopulu (Chryssanthie Panayotopoulou) un pateicās par brīnišḳīgo iespēju arvien piedalīties klasiskās filologijas studentu un docētāju rīkotajos pasākumos un runāt savā dzimtajā valodā, kā arī citēja Aishila kapa epitāfiju:

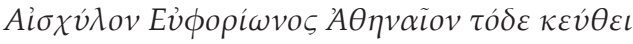

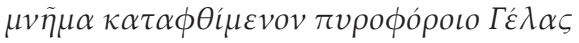

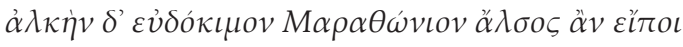

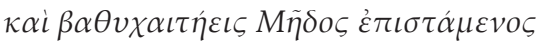

Atēnu Aishils šeit atdusas, Euforionam dēls

Kapakmens Gēlā tam, bagātā kviešiem, tik cēls

Stāsta lai vairāk birzs Maratonlaukā par mani

Garmatains persietis noteikti atceras arī

(Anthologiae Graecae Appendix, vol. 3, Epigramma sepulcrale p. 17, atdz. Iveta Skrastina)

Runas noslēgumā vēstnieces kundze Humanitāro zinātṇu fakultātes dekānei prof. Ilzei Rūmniecei pasniedza simbolisku dāvanu - ierāmētu senu plakātu, kurā attēlots slavenais grieḳu olimpionīks Spiridons Luiss, pirmais maratona distances uzvarētājs pēc moderno olimpisko spēḷ iedibināšanas 1896. gadā, kad maratons (42 km - aptuvenais attālums no Atēnām līdz Spartai) tika iekḷauts spēḷu programmā kā jauna disciplīna.

Sadarbojoties LU Bibliotēkai (īpašs paldies direktorei Ivetai Gudakovskai, direktores vietniecei Mārītei Savičai) un Grieķijas vēstniecībai, tika izveidota izstāde Maratonas uzvarai - 2500, arī tā tika atklāta šai 
pasākumā. (No 30. decembra līdz 15. februārim izstāde bija aplūkojama Humanitāro zinātṇu bibliotēkā Visvalža ielā.) No LU Bibliotēkas krājuma tika izstādīti antīkie avoti, kuros pieminēta vai atainota Maratonas kauja, piemēram, Tukidīda Vēsture (origininālā un tulkojumos ang̣̣u, vācu un krievu valodā) un Pausānija Griekijias apraksts, kā arī 19. gs. angḷu izdevumi, piemēram, Elizabetes Brauningas izdevums The Battle of Marathon (Maratonas kauja) (1820) un Roberta Brauninga grāmata Pheidippides (Feidipīds) (1879), kā arī 20. gs. vēsturnieku, klasiskās filologijas pētnieku un zinātnieku darbi, kas veltīti nozīmīgajam notikumam.

Pasākuma izskaṇā ikviens tika aicināts uz tradicionālo dionīsisko daḷu, kurā varēja cienāties ar īpašu Maratonas uzvaras torti un ne nu

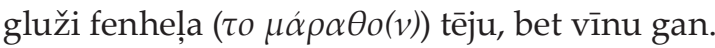

Kur nu kurš esam aizsteigušies un aizskrējuši, ko nu kurš esam un neesam paspējuši, bet lai ikvienam spēks un izturība arvien jaunu uzvaru sasniegšanā!

Nobeigumā - neliels veltījums Maratonai:

Mùsdienu ikdiena ir steidzīga

Aizrit stundas un gadi un gadsimti

Rìti un vakari drīzōk ir sprinteri

Attālumi saraujas globalizāaijas riten $\bar{\imath}$

Tomēr distances vieglākas nekḷust

Otršķirīgas ir bailes ir jāgrib

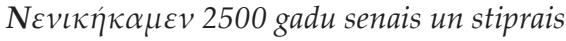

Atl̦auj vēl šodien mums pasmelties pārliecību

Pateicībā visiem pasākuma organizatoriem un dalībniekiem Iveta Skrastina

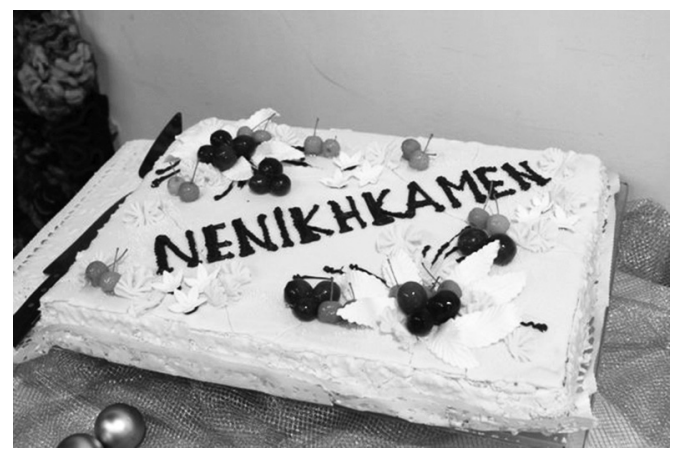


ROMAI - 2765

2012. gada 24. aprīî̄ Latvijas Universitātes (LU) Humanitāro zinātṇu fakultātes (HZF) Klasiskās filologiijas un antropologiijas studiju nodaḷas Klasiskās filolog̣ijas katedra un Latīniskā kultūrmantojuma centrs aicināja interesentus uz Atklāto tulkošanas semināru, kas tika veltīts Romas dibināšanas 2765. gadadienai. Tulkošanas semināra rīkošana aprīilì, kad Roma atzīmē savu dibināšanas dienu, Klasiskās filologijas un antropoloǵijas studiju nodaḷā jau izveidojusies par tradīciju. Studentiem-klasiķiem tā ir iespēja parādīt savu varēšanu atdzejošanas mākslā. Ar gandarījumu jāatzīmē, ka jaunie klasiḳi nodemonstrēja l̦oti labi vērtējamus tulkojumus. Tas nozīmē, ka veidojas jauna talantīgu atdzejotāju paaudze - tātad ir cerība, ka reiz visa Senās Romas dzejnieku sacerētā dzeja būs baudāma arī latviešu valodā. Seminārā izskanēja Ovidija un Horācija dzejas fragmentu latviskojumi. Tos bija sagatavojuši otrā un trešā kursa studenti-klasiḳi Eva Folkmane, Renāte Prancāne, Santa Stopiņa, Rita Prelgauska, doktorante Ilona Gorn,eva, Baltistikas nodaḷas maǵistrants Roberts Šestaks, kā arī Klasiskās filoloǵijas maǵistra

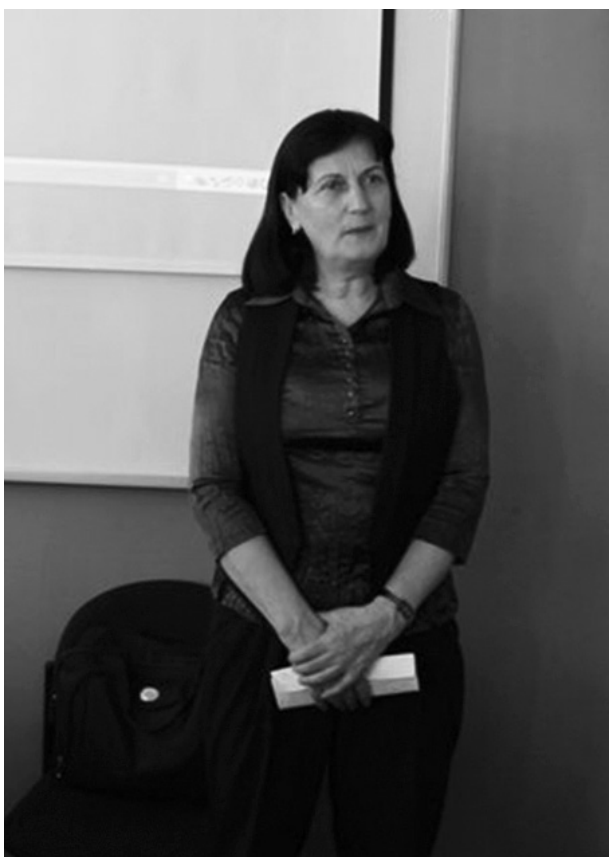

Semināru organizēja Latīniskā kultūrmantojuma centra vadītāja docente Brigita Cîrule 


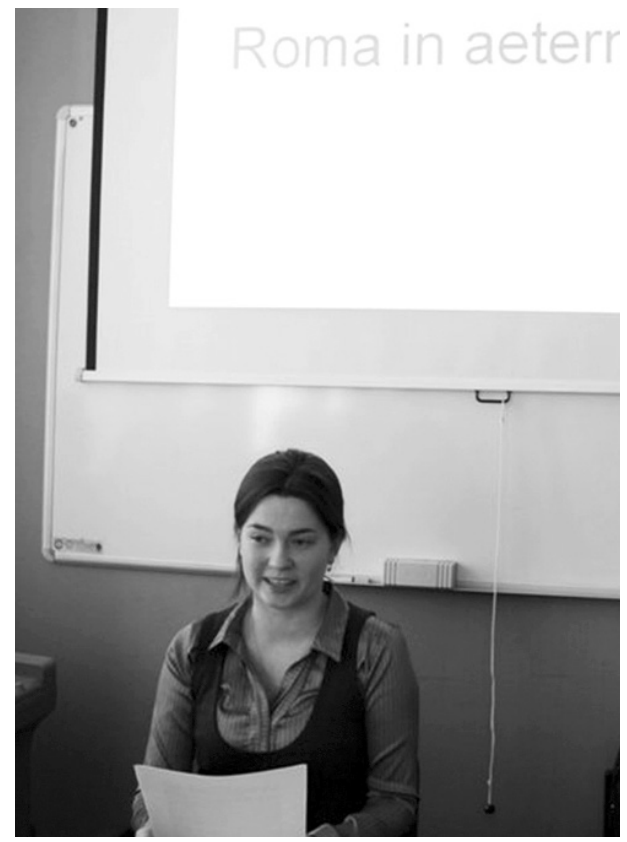

Vivita Daṇiḷeviča ievadīja semināru, stāstot par Romas pirmsākumiem un par pasākumiem, kuri tiek organizēti mūsdienu Romā, atzīmējot pilsētas dibināšanas dienu

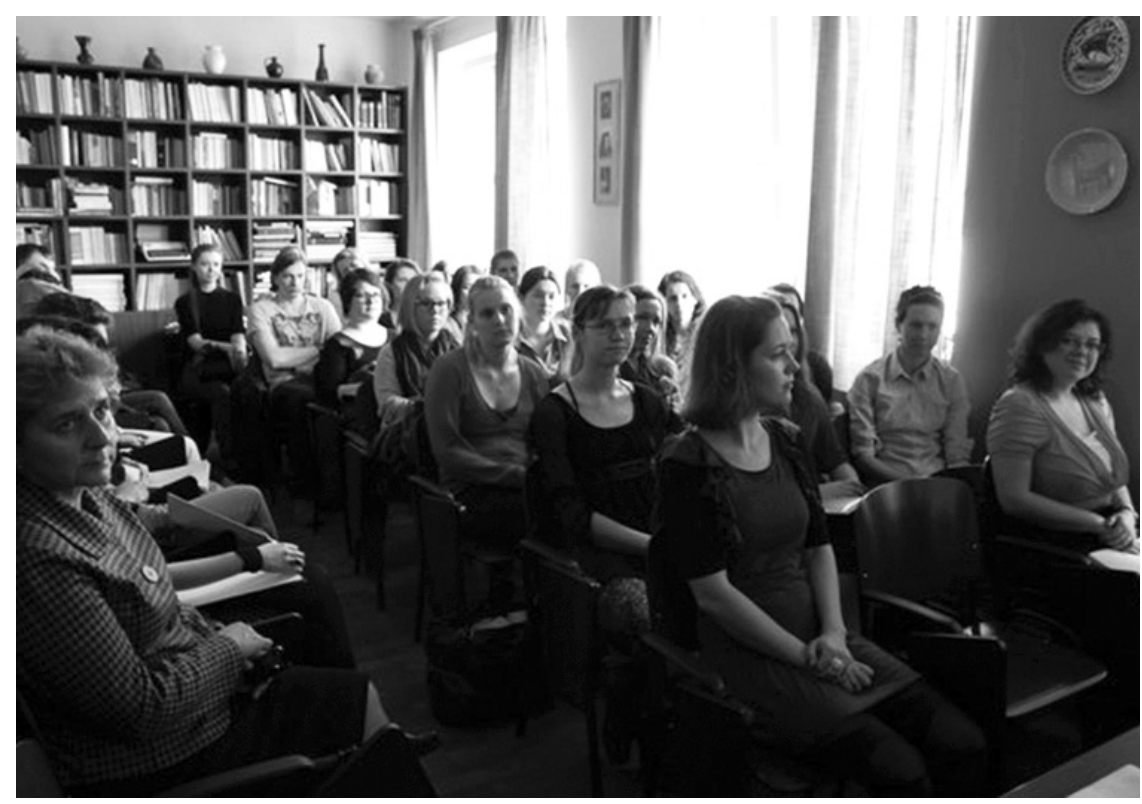

409. auditorija, kurā notika seminārs, bija pilna ar interesentiem 


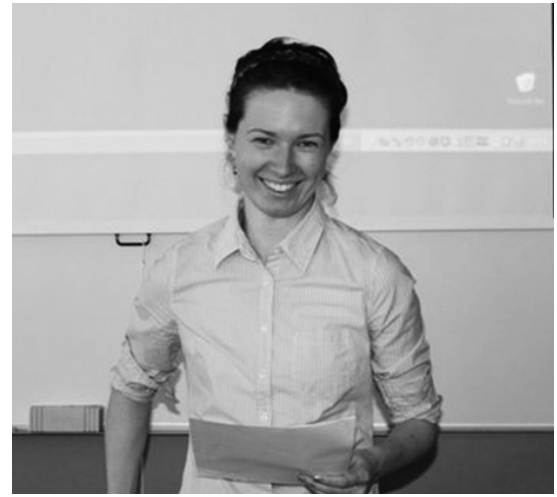

Patrīcija Patmalniece nolasīja Roberta Šestaka atdzejoto fragmentu no Ovidija poēmas Metamorfozes

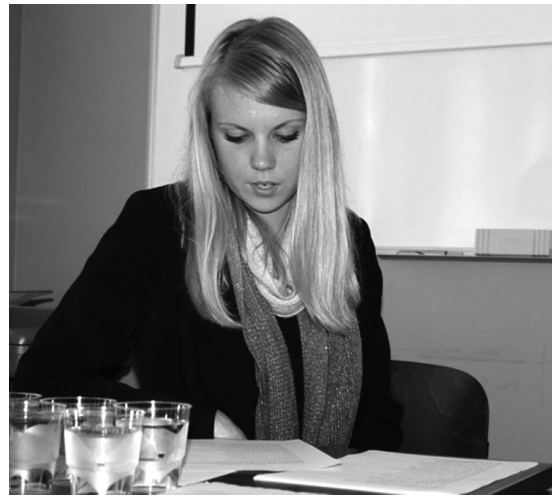

Santa Stopina nolasija fragmentu no Ovidija poēmas Fāsti atdzejojumā

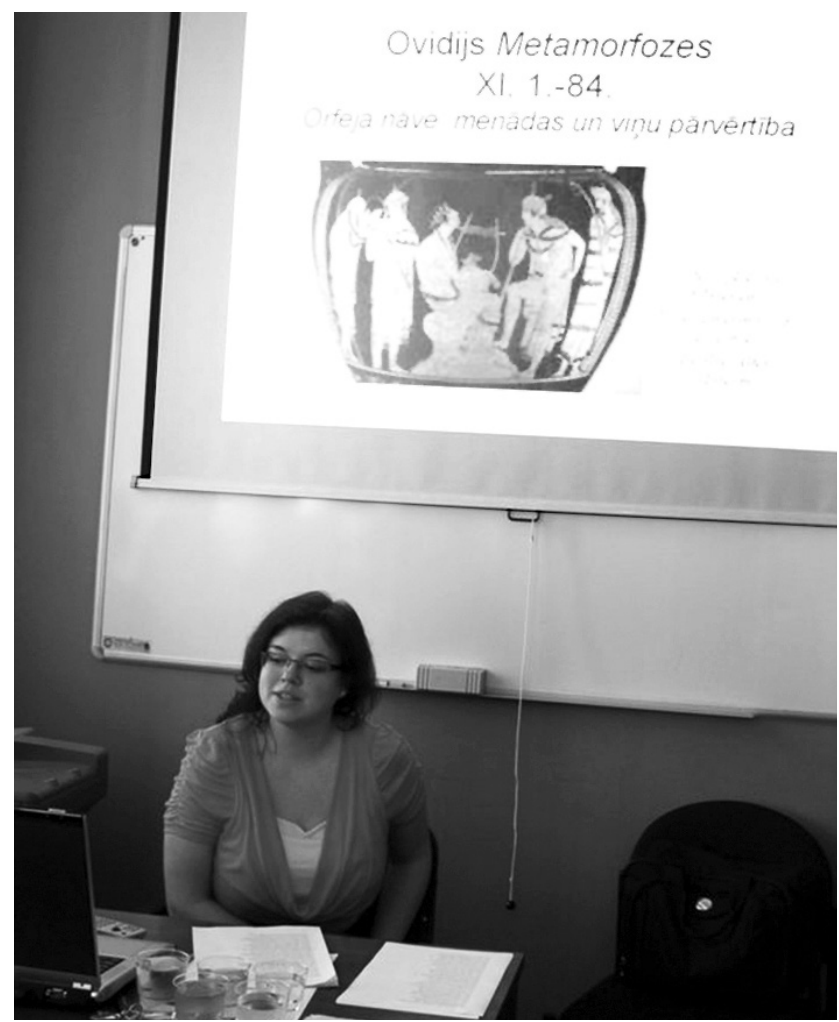

Ilona Gorņeva, lieliski izjūtot Ovidija tēlu pasauli un valodu, piedāvāja fragmentu no poēmas Metamorfozes skaistā atdzejojumā 


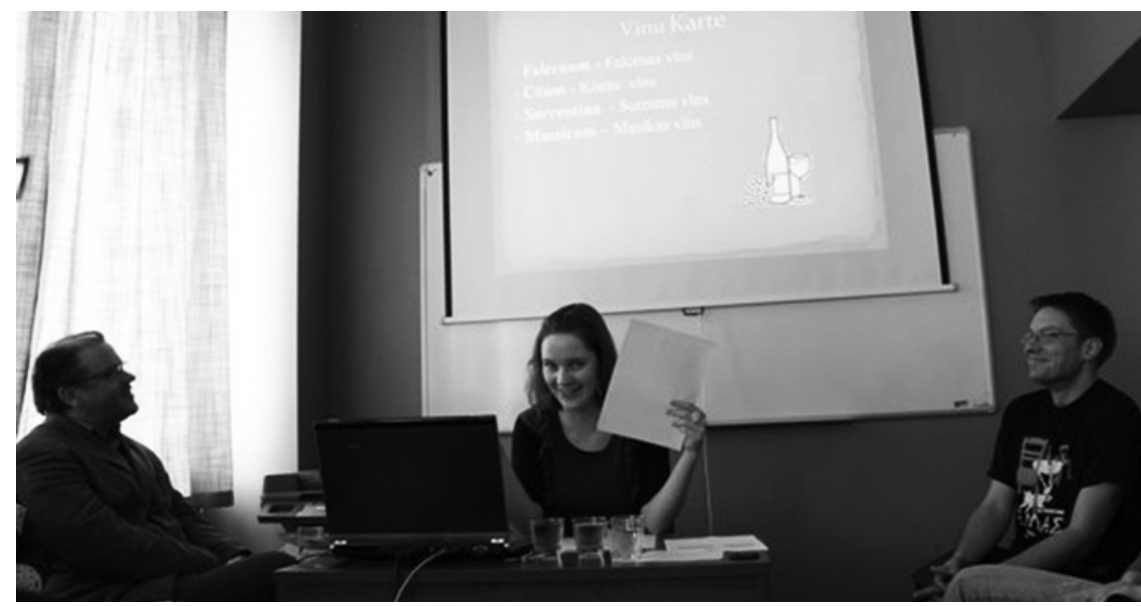

Līva Bodniece ḷoti atraktīvi prezentēja fragmentu no Horācija dzejas, ko bija atdzejojusi kopā ar Lauru Freidenfeldi

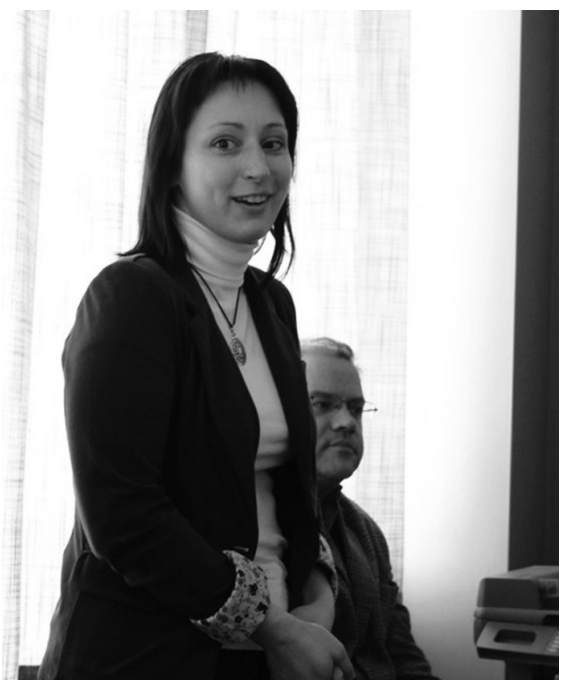

Semināra noslēgumā atzinīgus, uzmundrinošus vārdus jaunajiem atdzejotājiem teica Klasiskās filologijas katedras vadītāja docente Gita Bērziṇa

studiju programmas absolventes Livva Bodniece un Laura Freidenfelde. Aizraujošu prezentāciju par Romas dibināšanu, atsaucot atmiṇā gan mītu par Romas dibinātājiem Romulu un Remu, gan arī sniedzot ieskatu par to, kā mūsdienu Romā tiek atzīmēta mūžīgās pilsētas dibināšana, piedāvāja pirmā kursa studente Vivita Daṇiḷeviča. 


\section{RECENZIJAS}

\section{REALITĀTE UN DZĒ ĚAMGUMIJA}

Strelēvica-Ošiņa, D. Kāpēe mēs gribam, lai valoda ir pareiza? Ieskats preskriptīoisma vēsturē, teorijā un praksēe. Rīga : LU Latviešu valodas institūts, [2011] 2012, 320 lpp.

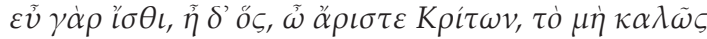

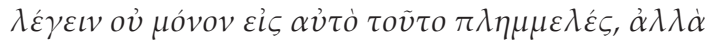

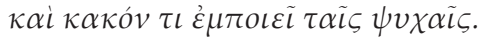

Jo tu labi zini, mans lieliskais Kriton, ka tas, kurš nerunā skaisti, kḷūdās ne tikai runāšanā, bet arī nodara kaitējumu dvēselèm. ${ }^{1}$

Plat. Phaedo, 115e

Daces Strelēvicas-Ošiņas [turpmāk tekstā lietosim pašas autores izvēlēto saīsinājumu D. S.-O. vai arī vārdu "autore"] pētījums ir vērtīga lasāmviela ikvienam, kas vēlas gūt ieskatu valodas normēšanas vēsturē. Savā ziṇā D. S.-O. rakstības stilā jūtams žižekisks svaigums un visaptvere, kas patīkami pārsteidz pēc ierasti sausajiem, ar faktiem, mērìjumiem un citātiem pārblīvētajiem pētījumiem citās valodniecības nozarēs, piemēram, akustiskajā fonētikā vai sintakses teorijās, kur tiek bīdīta heavy zinātne un izdarìti fundamentāli atklājumi, bet kuṛu

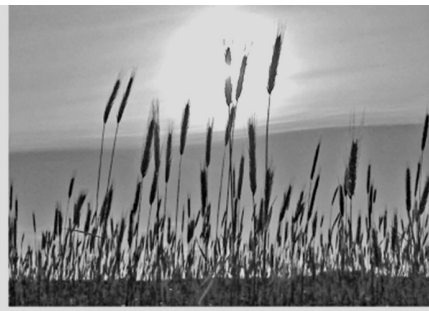

Dace Strelēvica-Ošina KĀPĒC MẼS GRIBAM, LAI VALODA IR PAREIZA?

leskats preskriptivisma vēsturē, teorijā un praksē

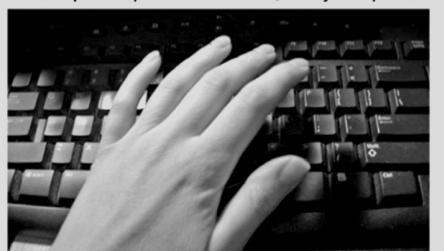
lasî̌sana, lai man piedod to cienījamie autori, vairākumā gadījumu robežojas ar mazohismu. Uzreiz ķer̦oties vērsim pie ragiem, teikšu, ka galvenais, kas mani - klasisko filologu - uzrunāja D. S.-O. grāmatā, ir pētījuma domas plašums. Nudien,

Autora tulkojumi. 
lasot 320 lpp. apjomīgo grāmatu, lasītājs tiek nevilšus ierauts refleksijā, kas viņu pavada vēl ilgu laiku pēc tam, kad grāmata ir jau aizvērta un ielikta plauktā. Teksts lasās viegli, tas ir porains un raits, un tajā ir arī kaut kas no senatnes - kā klasiskās, tā viduslaiku un apgaismības laiku universāluma, no tveršanās pie neaptverami lielā, pie valodas, Logos, kas neapšaubāmi prasa lielu uzdrīkstēšanos. Savā recenzijā nepretendējot uz pētījumā izklāstīto teoriju pārstāsta visaptverošu analīzi, es uzreiz atzīmēšu, ka pētījuma bagātība slēpjas tieši plašajā piemēru klāstā, ko D. S.-O. nobeṛ pār mums kā tādus konfeti, vietumis gan pārāk neaizraujoties ar to interpretāciju. Pārfrāzējot Brodska Ūdenszìmes (Watermark) beigu rindas, jāteic, ka valoda nudien ir lielāka par cilvēku un paliks arī tad, kad cilvēks jau būs aizgājis. To uzskatāmi pierāda arī šis pētījums. Bet, dzīvodami, domādami valodā, mēs atstājam tajā nemanāmas pēdas, un tā vienlaikus arī mainās katrā no mums atsevišksi un visos kopā. Varbūt tās mainību un mehānismus var salīdzināt ar Dieva darbiem un tautas dvēseles klātbūtni mūsos? Nāk prātā Eusēbija citētais sofists Protagors (ap 490.-420. g. p. m. ē.), kuŗš par dieviem ir teicis: $\pi \varepsilon \rho i \mu \dot{\varepsilon} v$

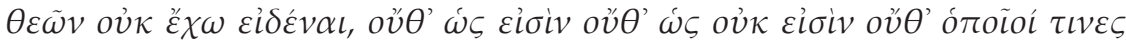

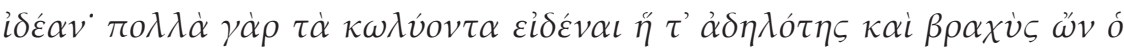

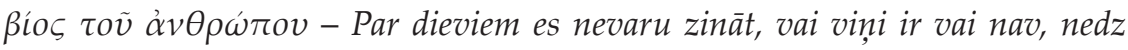
kā viņi izskatās; jo, raugi, ir daudz lietu, kas stāv ceḷā zināšanai - š̄ jautājuma neskaidrība un cilvēka dzìves īsums (80B4).

Tātad: par ko ir šis darbs? Kāpēc par to jāreflektē krājumā Antiquitas viva? Kur slēpjas tā klasiskās šķautnes un „rozīne”? Domāju, daḷeji uz to atbildi sniedz jau ievadrindkopā izklāstītie apsvērumi. Refleksija par kaut ko tik lielu kā valodu un pareizumu vai, attiecīgi, nepareizumu tajā neizbēgami liek mums atgriezties klasiskajā senatnē un atsaukt atmin̄ā antīkās filozofijas postulātus, sofistu pārdomas par valodas iedarbību, (šīs recenzijas epigrāfā liktā) Sokrata apceri par mūžīgo cīṇu starp dabisko $(\phi \tilde{v} \sigma \iota \varsigma)$ un tradicionālo, konvencionālo (vó $\mu$ s), romiešus, Ciceronu, Kvintiliānu. Atḷaušos patapināt „realitāti” un „dzēšamgumiju” no autores teksta 142. lpp. - tēlaini izsakoties, pētījums ir par realitāti (to, kā valoda attīstās dabiski) un par dzēšamgumiju (to, ko dažs labs no tās grib izskaust vai labot). Šķiet, tādā kā sokratiskā pazemībā (,zinu tikai to, ka neko nezinu" ${ }^{\prime 2}$ ), bet bez viṇa ironijas D. S.-O. pieskaŗas dažādiem „par un

2 Precizitātes labad jānorāda, ka šis plaši pazīstamais citāts tieši šādā formā Platona

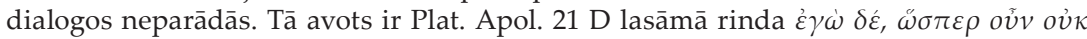

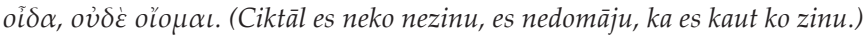


pret", uzdod daudzus jautājumus, tostarp arī daudzus retoriskus, neatbildētus un neatbildamus, līdz nonāk savveida pirroniskā skepticismā, kas, kā zinām, ir dzìves stils, kuṛā savienojas sprieduma apturēšana

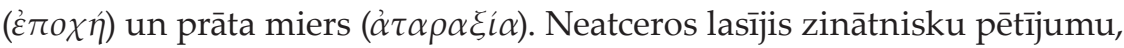
kuṛā būtu tik daudz jautājuma zīmju nodaḷu virsrakstos, arī piemēros un pašā pētījuma tekstā.

Jautājumi liecina par autores vēlmi - tieši vai ar izraudzīto piemēru starpniecību - komunicēt ar lasītājiem, veidot dialogu, bet tie arī izraisa uzticēšanos, jo neapšaubāmi liecina par godīgumu un atvērtību, pat ja vietumis varbūt pret tiem varētu celt iebildumus, ciktāl:

a) tie tikai izskatās pēc jautājumiem, bet būtībā ir nevis jautājumi, bet gan minējumi vai ierosinājumi, piemēram, 95. lpp. 32. zemsvītras piezīmē Iespējams, pēc analoóijas ar Dž. Tomasa (1991) minèto jēdzienu "apūristi" (kas nav vienādojami ar "antipüristiem"), te būtu lietojams termins "apreskriptìvisti"?;

b) tie sagaṛina tekstu, rīkojoties pēc studentiem labi zināmās metodes, kur apgalvojums tiek formulēts jautājuma formā un pēc tam vārds vārdā atkārtots, piemēram, Kas gan ir pidžinizācija un kreolizācija? Izdarot kopsavilkumu no dažādu valodnieku teorijām (..), var teikt, ka pidžinizācija un tai sekojošā kreolizācija ir (..) utt.; un - jau daudz nopietnāks pārmetums -

c) ar jautājumiem vietumis tiek implicēts apgalvojuma patiesums, resp., no jautājuma Kāpēc mēs gribam, lai valoda ir pareiza? logiski izriet Mès gribam, lai valoda ir pareiza.

Bet vai mēs tiešām gribam, lai valoda ir pareiza? Kas ir "pareizība” un „pareizums" valodā? Šis jautājums dažādās polaritātēs, jādomā, kṇudina un kairina ne vienu vien grāmatas adresātu, kuṛš uz tā uzķēries kā plekste uz dūṇās iemesta āḳa. Tāpat, bez šaubām, tas uzrunā arī dạ̣u akadēmiski izglītotās filologu publikas, tostarp šā raksta autoru, redaktorus, rakstniekus, apzinīgākos žurnālistus, skolotājus u. c. personas, kas, kā jau norādīju šā raksta sākumā, „vēlas gūt ieskatu valodas normēšanas vēsturē", tomēr man ir aizdomas, ka autore nedaudz pārvērtējusi ši jautājuma aktualitāti pasaulē „un latviešu sabiedrībā jo īpaši", jo, raugoties uz valodas kultūru kā starptautiskajos, tā pašmāju medijos, šāda vēlme vismaz pēdējos gados nav īpaši jūtama. Problemātiska šḳiet tēze: Ne bez iemesla gan katram indivìdam, gan katrai sabiedrībai un kultūrai ir savs viedoklis par valodas pareizību (11. lpp.). Domāju, ka mums nav pieejama statistika, kas šo apgalvojumu varētu 
drošticami ilustrēt. Runājot par maniem vērojumiem Latvijas un citu valstu medijos, jāatzīst, ka ir nācies lasīt daudz anonīmu komentāru internetā, daudz nekonkrētu izteikumu nostalǵiskos drukātos un elektroniskos forumos (no sērijas „agrāk bija labāk”), bet ir jākonstatē, ka vairākumā gadījumu plašākai sabiedrībai nav konkrētas, analītiskas pieejas, nav filozofisku pārdomu, kas pievērstos dziḷākajam jautājumam „kāpēc?", kāds ir normēšanas raison d'être, vai norma nenoplicina, nesterilizē, nepadara valodu nabadzīgāku?

Kas gan ir pareizība sub specie aeternitatis, cik tai vispār ilgs mūžs valodas pārmaiṇu vējos? Šajā ziṇā D. S.-O. darbs patiešām ir zelta vērts, jo tas tieši vai netieši pieskaŗas daudziem no iepriekš minētajiem aspektiem. Oriǵināla ir autores ideja par starptautu naida sublimāciju preskriptīvās teorijās. Izziṇu bagātinošas (un labi izstrādātas) ir pasāžas par preskriptīvisma fonu - politkorektumu, hiperkorekciju, valodas mītiem un valodu izzušanu, ekskursi Senajā Romā un ieskats Rietumeiropas pūrismos un Kvebekas situācijā.

Filologa objektivitātes pienākums liek man arī minēt vismaz dažus trūkumus, kas duṛas acīs un var potenciāli diskreditēt šā darba zinātnisko ètosu. Jādomā, tie saistīti ar dažādiem objektīviem apstākḷiem.

Kā pirmais trūkums būtu minama dažu personvārdu neprecīza, nekonsekventa vai pat aplama atveide. Tā, piemēram, Pīters Tradžils (Trudgill) atbilstoši izrunai Apvienotajā Karalistē, manuprāt, būtu atveidojams kā Tradgils, persona, ko oriǵinālā sauc Katie Wales, varētu būt Veilza, nevis Veilsa, turklāt, ja Katie atveidojam kā Keitija un David kā Deivids, tad arī Lakoff būtu jāatveido kā Leikofs, nevis Lakofs, un Chambers kā Čeimberss, nevis Čamberss. Cerquiglini no franču valodas noteikti ir Serkiljinī (nevis Serkvilini), bet, pat ja pien,emam, ka atdarināts ir no itāḷu valodas, jādomā, kas ir šā uzvārda cilmes valoda, un tad pareizi būtu Čerkviljīni. Dubultvārds Lūi-Nikolā Bešerels (Louis-Nicolas Bescherelle) latviski rakstāms bez defises, t. i., Luī Nikolā. Arī diakritiskās zīmes ne visur lietotas konsekventi, tā, piemēram, Nenads Miščevičs oriğinālā noteikti nebūs Nenad Miscevic, bet gan Nenad Miščević. Sīkas neprecizitātes manāmas arī citvalodu citātu pareizrakstībā, piemēram, 90. lpp. minētā Academie Française pareizi rakstāma Académie française (kā iepriekš 88. lpp., kur ir pareiza rakstība). Ar lielajiem burtiem un akcentiem misējies arī 272. lpp., kur lasām la Revolution Tranquille; the Quiet revolution, lai gan franču nosaukumā pareizi būtu la Révolution tranquille, bet anglu - the Quiet Revolution. 
Vietumis autore ir „izgudrojusi divriteni” filologiskajā terminologijāā, piemēram, tāds šḳiet viṇas proponētais „avarējušais prievārds” (stranded preposition). Manuprāt, veiksmīgāk to būtu saukt par atdalīto vai izolēto prievārdu, īpaši tāpēc, ka preposition stranding vietā nereti lieto arī preposition dangling, kas arī izsaka atdalīšanās, atvienotības nojēgumu. Vācu valodā šo parādību dēvē par Spaltungskonstruktion, kur atškcelšanās ideja ir vēl skaidrāk izteikta. Šāda konstrukcija ir sastopama arī skandināvu valodās. Tomēr nevar nepiezīmēt, ka piedāvāti arī daudzi derīgi terminu latviskojumi, piemēram, slēptais preskriptīvisms (obscure prescriptivism), izzušana (obsolescence) un daudzi citi.

Darbam noteikti nebūtu kaitējusi arī literārā redaktora un vērīgāka korektora acs: 228. lpp. lasām teikumu: Arī I. Druviete uzsver: "Atkāpi no normas gan var var izgaršot tikai tad, ja norma ir zināma." Nekonsekventa ir vārda "atmoda” rakstīšana te ar lielu, te ar mazu burtu. Tā lasām lìbiešu atmoda, pirmā Atmoda, latviešu pirmā nacionālā atmoda, otrā atmoda, Atmodas priekšvakars, tā dēvētā treša atmoda, latviešu tautas tā dēvētā pirmā un trešā atmoda, Kvebekas nacionālā atmoda utt. Tekstā palikušas tādas stila pērles vai pārcēlumi kā pielietot vardarbību (= vērst pret kādu vardarbību, izturēties vardarbīgi), preskripcijas (= priekšraksti), sensitīos jautājums (= delikāts, kutelīgs jautājums), dažādu valodu un valodu saimju runātāji (= ???). Vietām jaukta kopā es un zinātniskā/objektīvā mēs forma (176. lpp. Jau iepriekš minējām secīgo procesu virkni..) kas rada stilistiski neviendabīgu iespaidu. Palaikam trāpās arī pretrunīgas frāzes: Tāpēc pēdējo pārdesmit gadu laikā arvien vairāk Rietumu sociolingvistu iedzilininās preskriptīvisma fenomenā, saprotot, ka šis parādības aizslaucīšana vēstures mēslainē ir bijusi pārsteidzīga un varbūt nemaz nav iespējama (10.-11. lpp.). Ja jau reiz bijusi aizslaucīta mēslainē, tad to ir bijis iespējams izdarìt. Bet nevar izslēgt arī pārpratuma iespēju no šìs recenzijas autora puses. Pārpratumu un kḷūdu iespēju darbā ar valodas materiālu nekad nevar izslēgt. Resp., gan recenzijā, gan pētījumā. Uz pārpratuma, šḳiet, balstās D. S.-O. lingvistiskās parodijas piemērs 227. lpp., proti, jūŗas kŗupim grāōi gr̛ūti - tā nav nekāda lingvistiska parodija, kas ironizē par palatālā ",r, lietojumu, ievietojot to arī tādās pozīcijās, kur tam standartvalodā nebūtu jābūt. Šajās pozīcijās Endzelīna ortogrāfijā šai fonēmai vai nu ir jābūt, vai tā var būt (piem., vārdā krupis/kṛupis) - formas ar mīksto ṛ sastopamas visos šajos vārdos Mīlenbaha-Endzelīna vārdnīcā, kurpretim Grīsles raksta nosaukumā vārdā labdarīgs tam gan nav jābūt (123. lpp. Vai galīgi nogalēsim labdarigo r un ch?). 
Runājot par latviešu valodas normēšanas vēsturi, manuprāt, būtu bijis noderīgāk atsaukties nevis uz Inas Druvietes rakstu LZA Vēstīs, kas atstātītā formā šḳiet sniedzam to pašu informāciju, kuṛa rodama daudz pamatīgākajā Artura Ozola pētījumā Veclatviešu rakstu valoda (1965) - tas iekḷauts literatūras sarakstā, bet izmantots nepietiekami, tikai vienu reizi un bez lappuses norādes. Konkrēti, runa ir par citātu 176. lpp.: .. kā norādījusi I. Druviete, apzināta valodas normalizācija Latvijā sākusies 17. gadsimtā, kad publicēti pirmie ìstie normu avoti - vārdnīcas un gramatikas grāmatas (I. Druviete 1991, 43-48). A. Ozola pētījumā norādīts, ka 17. gadsimtā sākas latviešu rakstības apzināta normēšana (10. lpp.), un tālāk minētas ne tikai Druvietes norādītās vārdnīcas un gramatikas, bet arī apcerējumi Latviešu literārās (t. s. draugu) biedrības rakstu krājumā Magazinnas un traktāti ar konkrēti norādītiem autoriem un gadiem (12.-13. lpp.). Manuprāt, trūkst kritiska novērtējuma 176. un 177. lpp. minētajiem anahroniskajiem, pat anekdotiskajiem J. Kušķa citātiem, kuṛos valoda vērtēta melnbalti, emocionāli un klaji nezinātniski (piemēram, vin,š lībiskā dialekta ietekmi uz Rīgas valodu sauc par iezīmēm, bet vācu valodas pienesumu - par piesārn,ıjumu). Tiesa, J. Kušķim nenoliedzami ir vērojumi nopelni latviešu valodas kultūras tradīciju kopšanā un pilnveidošanā. Tā vietā D. S.-O. mums piedāvā minējumus par to, kas būtu, ja būtu (G. Manceḷa ieviestās pārmaiņas varbūt iezìmēja vēl nozìmīgāku pagrieziena punktu latviešu standartvalodas attīstībā, nekā pierasts domāt - ja š̀s reformas nebūtu bijis un ja viña preskripcijas nebūtu sākuši ievērot arī Rìgā dzīvojošie autori, varbūt mūsdienu latviešu standartvaloda tagad lìdzinātos lībiskajam dialektam? 177. lpp.). Šādi pārspriedumi ab initio ir lemti neveiksmei, jo, lai proponētu Manceḷa Vademecum (Rokvedis, pirmais izd. 1631. g.) un Lettus un Phraseologia lettica (1638. g.), kā arī Lettische Postill (Sprediḳu grāmata, 1654. g.) preskriptīvo raksturu, būtu jāpierāda, ka tieši šīm grāmatām ir bijusi ietekme uz tā laika lasošo un rakstošo publiku. Eiropas valodu vēsture liecina, ka konkrēta dialekta iesakṇošanos nereti veicina ārpusvalodiski faktori, piemēram, franču 'standartvalodas' nostiprināšanos ir veicinājusi valsts varas centralizācija pēc Lielās franču revolūcijas, itāḷu valodas vēsturē vispāratzīts ir apstāklis, ka 'standartvalodas' nostiprināšanās ir notikusi, pateicoties Itālijas valsts apvienošanai, armijai un 20. gadsimtā arī plašsaziņas līdzekḷu izplatībai (radio, televīzija), bet par Manceḷa grāmatu metienu un apriti nekas droši nav zināms. Manuprāt, nav gluži pamatoti arī runāt par preskripcijām (saistošām norādēm? 14. lpp. šis termins skaidrots kā mākslīga iejaukšanās), jo 
A. Ozols norāda, ka rakstība Mancel̦a darbos ir vēl ḷoti svārstīga, tālāk sniedzot A. Augstkalna (1930) citātu: Mancelis iznīcināja pirmo rakstu valodu, to pārspēdams. Tā mums šodien liekas. Bet ne tā Manceḷa laika biedriem... Ne visi tūlin, visādā zin̄ā saprata Manceḷa virsroku. Mancelis pats sakās zaimu zobiem kosts (..). Un ja arì saprata un atzina, tad ne jau tik viegli varēja iemācìties visu .. (Sīkāk sk. jau minēto Ozola pētījumu, 164.-165. lpp.)

Visbeidzot, šo rindu autoram nav skaidrs, uz kādu zinātnisku kritēriju pamata nošķirts uz valodu orientētais preskriptīvisms, kas saistīts ar sabiedrības vai indivìda vēlmi sargāt valodu no iedomāta pagrimuma, it īpaši citvalodu interferences rezultātā (..), un uz kḷūdu orientētais preskriptīvisms, kas saistīts ar vēlmi izcelt, stigmatizèt, kritizèt un iznīcināt dažădas ìstas vai škietamas valodas kḷūdas (gandrīz katrā kultūrā ir kādas ìpaši "populāras" kḷūdas, kas izpelnās preskriptìvistu vislielāko uzmanību) (285. lpp.), ja pie pirmā kā valodu degradējošs faktors ir minētas tās pašas kḷūdas (92. lpp.).

Kā jau iepriekš norādīju, darbs rosina uz plašu refleksiju par tēmu, par kuṛu nopietnas zinātniskas diskusijas latviešu kultūras telpā vismaz pēdējā laikā nav. Manis norādītie trūkumi un nepilnības - it īpaši pareizrakstības un stila jomā - pielaidīgākā lasītājā var modināt asociācijas ar matu skaldīšanu, tomēr tie šḳita atzīmējami, ìpaši ņemot vērā darba tematu. Uzreiz gan atzīmēšu, ka vairākumā gadījumu tie nav principiāla rakstura un neatspēko manu sākotnējo vērtējumu par darba vērtīgumu un autores uzteicamo drosmi un apneēmību art l̦oti plašu lauku. Lasot šo darbu, mani pat piemeklēja platonisko dialogu lasišanas déjà vu - tajos arī daudz kas paliek nepateikts un nesistematizēts un kopaina veidojas no atsevišşu sarunu druskām - D. S.-O. gadījumā tā veidojas no bagātīgā piemēru klāsta. Šis gan ir tīri asociatīvs, rotaḹigs salīdzinājums, jo Platona dialogi tomēr ir rakstīti "citā atslēgā", tiem ir pavisam cita virzìba. No filologiska pētījuma mūsdienās tomēr gribētos sagaidīt lielāku precizitāti un skaidrību. Kopumā n,emot, D. S.-O. darbu raksturo radoša nenoteiktība, inconclusiveness, daudzie varbūt un laikam autores secinājumos nelauj īsti saprast, kurp tad ir aizpeldējis pats D. S.-O. kuğis šajās preskriptīvistu un deskriptīvistu naidīgo virpuḷu sakultajās vētrās, vai tas nav "strandējis” (pun intended)? Varbūt laika gaitā un pēc jauna empīriska materiāla apstrādes tas arī kaut kur pietauvosies. Pagaidām mums paliek autores piedāvātais daudzpusīgais, uz domas lidojumu aicinošais universālais valodtvērums, kas ir tikpat godīgs, cik pasaule sarežğīta. 


\section{R İGAS HELLĒNIADE JEB AKADĒMISKAIS OLIMPISMS}

Modern, just like ancient Greece, has unique importance for everyone who is trying to find himself.

(Henry Miller)

Mūsdienu Grieķija, gluži tāpat kā Sengrieķija, ir neatkārtojami nozīmīga ikvienam, kurš cenšas iepazìt sevi.

(Henrijs Millers)

Lūkojoties jau trešajā Rīgas starptautiskās hellēnistikas konferences priekšlasījumu rakstveida apkopojumā, vērīgs lasītājs, kam sveši nav arī divām iepriekšèjām konferencēm veltītie rakstu krājumi, pamanīs, ka šoreiz ievadā ir izpalicis kāds programmatisks iešūpinājums hellēṇu un hellēnistikas pasaulē ar kāda nopietni jūsmīga vai grūtsirdīgi asprātīga izteikuma palīdzību. Proti, jau ierastais amerikāṇu rakstnieka Henrija Millera vērojums, ka .. nav ne senās, ne jaunās Griekijas, ir tikai viena - pasaule, kas iecerēta un radīta uz mūžiem, šoreiz ir atstāts ārpus grāmatspiedes, taču nav arī piemeklēts līdzvērtīgs aizvietotājs, kas varētu apkopot 2009. gadā Rīgā norisušās 3. starptautiskās hellēnistikas konferences

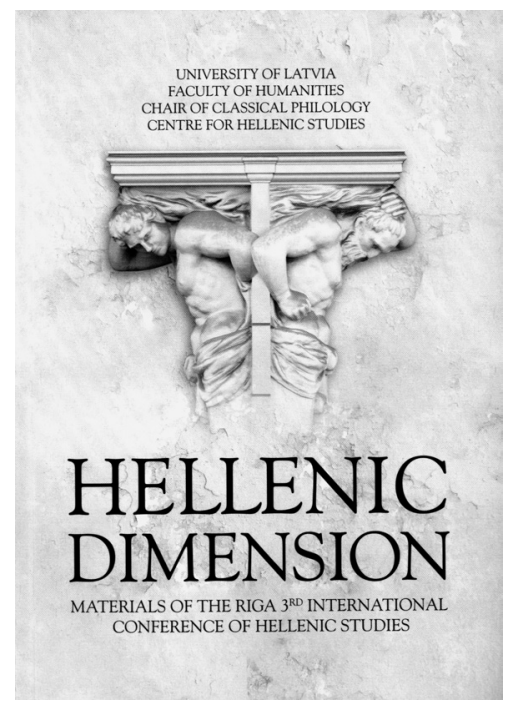

Hellenic Dimension : Materials of the Riga $3^{\text {rd }}$ International Conference of Hellenic Studies. B. Aleksejeva, O. Lāms, I. Rūmniece (Eds.). Riga : University of Latvia 2012, p. 270. 
pieredzi vienā (as)prātulā. Tam, visticamāk, iemesls ir hellēniskā kultūrkoka sažuburošanās - kā norādīts rakstu kopas ievadā un arīdzan uz 4. vāka - kopumā arvien plašākā (vienlaikus arī šaurākā - atsevišḳu padziḷinātu pètījumu gadījumā) un kuplākā pētīto un apspriesto priekšmetu lapotnē, kas vairs neḷauj izdarīt virspusēji vispārīgus novērojumus par hellēņu pasauli un tās ietekmi mūsdienās.

Kā liecība tam norādāmi kaut vai satura rādītāji visiem trim līdz šim iznākušajiem šo konferenču materiālu sakopojuma izdevumiem pirmajā laidienā saturs ir viengabalains un bez sīkākām iedaḷām, taču, sākot ar otro grāmatu, ir divas lielas daḷas, kas attiecīgi nosauktas par hellēṇu mantojuma Ģenēzi un Recepciju. Turklāt zīmīgi, ka trešajai konferencei veltītajam izdevumam Hellenic Dimension grāmatas viela tiek iekārtota nu jau trīs sadaḷās - Senlaikos, kas atbilstu iepriekšējai Ģenēzei, un Jaunlaikos un Atbalsīs un Atspulgos, kas kopīgi veiktu tālāku Recepcijas izvērsumu. Tas nepārprotami norāda, ka gan Latvijas hellēnofilo zinātnieku, gan arī ārzemju pētnieku piedāvātais apzināto priekšmetu klāsts kḷūst arvien ražīgāks, kā arī konferences apmeklētāji ar katru četrgadi ir tapuši arvien zinīgāki un sagatavotāki daudzveidīgāku hellēnisko kultūrparādību uztveršanai. Šāds nemitīgi pieaugošs pētījumu skaita un apskatīto laikmetu vairojums ārkārtīgi zīmīgi sasaucas ar konferences rīkotāju ievēroto senatno olimpisko pieeju, kas pārnesta uz mūsdienu akadēmisko pasauli, - konference tiek rīkota ik četrus gadus, savukārt no mūsdienām tiek aizgūta pieeja katrās nākamajās olimpiskajās sacīkstēs kuplināt iekḷauto sporta veidu skaitu, tādējādi panākot gan dalībnieku, gan vērotāju (un līdzpārdzīvotāju) lielāku daudzumu.

Lai gan iepriekšējām konferencēm veltītie izdevumi līdz šim bijuši paredzēti galvenokārt Latvijas cilvēkzinātṇu pārstāvjiem, līdz ar šo izdevumu, atškirīibā no iepriekšējiem diviem, ir notikusi pāreja uz angḷu valodas teju vai visaptverošajiem laukiem, latviski sniedzot vien īsus priekšlasījumu un priekšstādījumu kopsavilkumus. Domājams, ka šāda pieeja izvēlēta, lai jaunākie pētījumi, apkopoti vienā izdevumā, būtu pieejami saprotamā valodā arī plašākai pasaules hellēnistu sabiedrībai (n,emot vērā arì to, ka 3. konferences dalībnieki pārstāv daudz vairāk un dažādākas valstis nekā iepriekš), nevis tie pastāvētu kā vientuḷi un nomaḷi kultūr(arte)fakti tikai vietējām vajadzībām. Tādējādi šis izdevums taisnības labad būtu jāsauc par vienvalodīgu, starptautiskai apritei paredzētu, lai gan ietverti arī kopsavilkumi latviski, lai netiktu zaudèta vietējo lasītāju uzmanība un cieņa, kā izsakās Ilze Rūmniece - viena no sastādītājām. 
Priecē, ka, visādi izmēǵinoties iepriekš, krājuma iekārtojums ir ieguvis zinātniski pilnveidotu un jebkuram ārpuszinātniskam lasītājam izprotamu, un, kas visbūtiskāk, vienlaidus ieturētu veidolu - rakstu sākumā ir îss kopsavilkums un atslēgvārdi angḷu valodā, zemsvītras piezīmes vai atsauces ir sniegtas raksta ietvaros, nevis kā Hellēnu mantojumā (2. Rīgas starptautiskās hellēnistikas konferences rakstu krājumā) apkopotas vienuviet, sarežğỉjot katra atsevišḳa raksta lasāmību, vai Hellēņu dimensijā Eiropai (1. Rīgas starptautiskās hellēnistikas konferences priekšlasījumu apkopojumā) sniegtas pēc katra raksta.

Kā jau iesākumā tika minēts, šoreiz krājums palicis bez kapitę̧a, kas būtu kā vainags, zem kura sakḷāvušies visi ietvertie raksti, tomēr skaidri redzams, ka tā ir droša zīme hellēnistikas pētniecības attīstībai, un visi pētnieki gan katrs atseviški, gan arī kā kopīga vienība reizi četros gados turpina Henrija Millera manierē meklēt visdažādākos ceḷus - gan ar mūsdienu, gan seno hellēṇu, gan arī hellēṇu mantojumu pārṇēmušo tautu dažādo kultūrvērtību un laikmetzīmju palīdzību - uz mūžīgo Helladu. 


\title{
III AIZSTĀVĒTIE PROMOCIJAS DARBI
}

\author{
BRIGITAS KUKJALKO PROMOCIJAS DARBS \\ SENGRIEKGU FILOLOĢISKO TEKSTU VALODA
}

2011. gada 2. martā Latvijas Universitātes Latvijas Universitātes Valodniecības zinātṇu nozares promocijas padomes atklātā sēdē Latvijas Universitātes Humanitāro zinātṇu fakultātes Klasiskās filologijas katedras lektore Brigita Kukjalko sekmīgi un teicami aizstāvēja promocijas darbu Sengriek,u filoloğisko tekstu valoda un ieguva filologijas doktora zinātnisko grādu klasiskajā filologijā. Pēc vairākiem gadu desmitiem tas bija pirmais valodniecības zinātṇu nozarē klasiskās filolog̣ijas apakšnozarē aizstāvētais promocijas darbs.

\section{FRAGMENTI NO PROFESORA OJĀRA BUŠA RECENZIJAS}

„.. Brigita Aleksejeva (tagad - Kukjalko) savā promocijas darbā uzrāda tiešas paralēles (vai pretstatijumus) starp sengrieķu autoru filologiisko tekstu valodu un mūsdienu zinātnisko sacerējumu valodu, un šis sastatījums veido vienu no šīs disertācijas vadmotīviem.

Disertante savā pētījumā detalizēti izanalizē triju sengrieķu filologisko tekstu valodu; šie teksti ir Aristoteḷa Rētorika (daḷēji), Dionīsija Halikarnāsieša Par vārdu savienošanu un Hermogena Par izteiksmes veida paveidiem (daḷeji); izmantoto tekstu kopapjoms - apm. 60000 vārdu. Minētie teksti aptver sešu gadsimtu laikposmu - no 4. gs. pirms Kr. līdz 2. gs. pēc Kr.

Katrs no trim minētajiem tekstiem izanalizēts četros galvenajos aspektos: 1) autoru izmantotie jēdzienu apzīmējumi (mūsdienās teiktu: termini, taču disertante apzināti atsakās no mūsdienu termina termins lietojuma sengrieḳu kontekstā); 2) autoru individuālā viedokḷa izpausme tekstā (sengrieķu autori savu subjektīvo viedokli pauduši daudz nepārprotamāk, nekā to parasti pieḷauj mūsdienu zinātnisko tekstu redaktori; līdz ar to, kā pamatoti secina disertante [166. lpp.], arī autoru atbildība par uzrakstīto ir pamanāmāka); 3) valodas tēlainība (sengrieḳu filoloǵisko tekstu autori savā tekstā plaši izmantojuši gan metaforas, gan salīdzinājumu un hiperbolas iespējas); 4) avotu izmantojums sengrieḳu filologiiskajos tekstos (viena no savdabībām: citu autoru darbi bieži vien citēti, attiecīgā darba autoru nenosaucot, jo par galveno uzskatīts saturs, 
nevis autorība; savukārt teksti, kas citēti kā valodas lietojuma piemēri, atbilstīgi arī mūsdienu pedagoǵijas nostādnēm, lielākoties izmantoti pozitìva piemēra funkcijā, tikai ḷoti retos gadījumos citēts negatīvi vērtēts valodas lietojums).

Kopumā autorei izdevies pārliecinoši pierādīt promocijas darba pamathipotēzi, ka sengrieḳu filoloǵisko tekstu valodas īpatnības ir mūsdienu humanitāro zinātṇu vidē lietotās valodas tipiskāko iezīmju pamatā. Dažreiz gan attīstība, kurai sākuma punkts atrodams šajā pamatā, resp., sengrieḳu filologiiskajos (un arī citos zinātniskajos) tekstos, divtūkstoš gadu laikā novedusi pie diametrāli pretējas nostājas, piemēram, pie autora atsvešinātības no zinātniska teksta jeb pie pseidoobjektivitātes, kas vismaz humanitāro zinātṇu tekstos nebūt nešķiet tik pozitīvi vērtējama. Bet te jau es kḷūstu pārāk subjektīvs, disertante vairumā gadījumu saikni starp senajiem un mūsdienu zinātnes tekstiem konstatē, bet izvērsti nekomentē (škiet, subjektīvākais komentārs ir jau pieminētais - par autoru atbildību).

No ne tik ticamiem apgalvojumiem varētu minēt tikai dažus sīkumus, piemēram, tēzi, ka sengrieķu filologiskajos tekstos rodami pirmie tekstuāli fiksētie mēǵinājumi dot apzīmējumus filologiskiem jēdzieniem. Šis apgalvojums acīmredzami ir patiess Eiropas kontekstā, taču nav pārliecības, ka neatradīsim filoloǵisku jēdzienu apzīmējumus vēl senākos, piem., senās Indijas un Ķīnas autoru tekstos.

Vēl viens sīkums - apgalvojums [165.-166. lpp.], ka ..mūsdienu zinātnes valodā pētījumam relevantu terminu definīcijas tiek uzskatītas par obligātu tās sastāodaḷu. Te gluži negribētos piekrist, par obligātām gan varētu uzskatīt diskutablu jēdzienu un terminu definīcijas, savukārt pie relatīvi aksiomātisku jēdzienu analīzes tomēr parasti ķeramies uzreiz, definīciju neatgādinot.

Disertācijas tekstā lietoti vairāki no latviešu valodas skatupunkta savdabīgi termini, piemēram, nosaucējvārdi un teicējvārdi; būtu gribējies pie pirmā lietojuma izlasīt arī to skaidrojumu. Varam gan skaidrojumu atrast glosārijos, taču tikai tad, ja izlasām visu glosāriju, kurš, protams, kārtots pēc grieķu terminu alfabēta. Un neatbildēts paliek jautājums, vai apzīmējumam nosaucējvārds, resp., övo $\mu \alpha$, kas Aristoteḷa glosārijā skaidrots kā lietvārds vai īpašības vārds, bet Hermogena glosārijā - tikai kā lietvārds, patiešām sešu gadsimtu laikā sašaurinājusies nozīme vai arī disertante nav tulkojot bijusi īsti konsekventa?

Pēc skaidrojuma vai komentāra (tāds nav atrodams arī glosārijos) ilgojas arī izteiksmes veida drēgnums. 
Pēc veiksmīgas promocijas darba Sengriek̦ filologisko tekstu valoda aizstāvēšanas 2011. gada 2. martā lektore Brigita Kukjalko pateicas sava darba zinātniskajai vadītājai profesorei Ilzei Rūmniecei par vērīgu darba vadīšanu

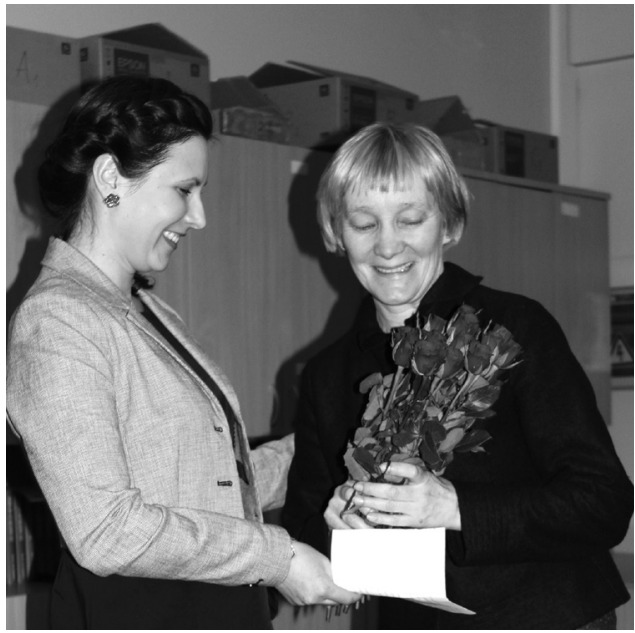

Vēl daži jautājumi.

Vai $\tau o ̀ ~ \varepsilon ́ \lambda \lambda \eta v i \zeta \varepsilon \imath v$ tiešām var uzskatīt par leksikologijas terminu (kā klasificēts 49. lpp.)? Tālāk, 50. lappusē teikts, ka mūsdienu skatījumā šis jēdziens šķistu vairāk attiecināms uz pareizrunu. Vai te tiešām domāta ortoēpija jeb pareizruna, vai varbūt tomēr plašāks nojēgums, ko mūsdienu terminologijā dēvē par valodas kultūru?

Kāpēc jēdziena apzīmējums $\sigma v \zeta v \gamma$ í $\alpha$ Dionīsija lietoto apzīmējumu glosārijā tulkots ar sajūgums, bet Hermogena glosārijā - ar saistījums; abi tulkojumi paši par sevi neizraisa iebildumus, bet vai konsekvences trūkums ir apzināts?

Ar terminoloǵijas jautājumiem robežojas kāds, šḳiet, tomēr tulkotāju viltus drauga lietojums. Aristotel̦a Rētorika (109. lpp.) raksturota kā ezotērisks darbs, ar to acīmredzot domājot tāds, kas nav paredzēts publiskam lietojumam; taču mūsdienu latviešu valodā - atškirīibā no grieḳu valodas - šādas nozīmes vārdam ezotērisks nav, ir vienīgi sašaurinātā, specializētā, ar reliǵiju un maǵiju saistītā nozīme. (..)

Izvēlēto sengrieķu filoloǵisko tekstu analīze ir paveikta skrupulozi, un par Brigitas Kukjalko promocijas darba saturisko pusi nekādu būtisku iebildumu nav. Cita starpā, nenoliedzami pozitīvi vērtējama sengrieķu filologisko tekstu aplūkojuma sasaiste ar mūsdienu zinātnes valodas problēmām. Brigitai Kukjalko par promocijas darbu Sengrieķu filoloğisko tekstu valoda būtu piešķirams filoloğijas doktora grāds valodniecībā, klasiskās filologijas apakšnozarē." 


\section{GITAS BĒRZINAAS PROMOCIJAS DARBS \\ DIALOGA ŽANRA TEKSTI SENGRIEKYU PROZĀ: LINGVOSTILISTISKAIS ASPEKTS}

2011. gada 3. maijā Latvijas Universitātes Valodniecības zinātṇu nozares promocijas padomes atklātā sēdē Latvijas Universitātes Humanitāro zinātṇu fakultātes Klasiskās filoloǵijas katedras docente (tobrīd - lektore) Gita Bērziṇa sekmīgi un teicami aizstāvēja promocijas darbu Dialoga žanra teksti sengrieķu prozā: lingvostilistiskais aspekts un ieguva filologijas doktora zinātnisko grādu klasiskajā filoloǵijā.

\section{FRAGMENTI NO PROFESORA OJĀRA LĀMA RECENZIJAS}

„Gitas Bērziṇas promocijas darbs Dialoga žanra teksti sengrieķu prozā: lingvostilistiskais aspekts ir moderns un novatorisks, jo ir starpdisciplināras ievirzes un materiāla izpētē balstās lingvistikā, literatūras zinātnē, komunikācijas teorijā. Vienlaikus pētnieciskais darbs mūsdienu humanitāro zinātṇu kontekstā dod jaunu elpu antīkās kultūras tradicionālai izpratnei par tekstu, kad lingvistiskais un literārais aspekts netika šḳirti.

Sengrieķu dialogu izpēte veikta ar mērḳi radīt vienotu izpratni par žanra vēsturi un savdabību lingvostilistikas aspektā, iezīmējot katra posma un autora īpatnības, kas pirmkārt izpaužas valodas lietojumā un organizācijā, bet caur to veido žanra pastāvēšanas un modifikāciju ainu.

Cieṇu un pat apbrīnu izraisa autores pamatīgā iedziḷināšanās dialoga izpētes vēsturē, par ko liecina plašais literatūras saraksts un pirmās divas darba nodaḷas, kurās aplūkota gan dialoga žanra vēsture antīkajā pasaulē, gan jo īpaši pamatīgi žanra izpētes vēsture, sākot ar antīkajiem autoriem, turpinot ar 19. gadsimta un 20. gadsimta sākuma klasiskās filolog̣ijas dižgaru veikumu un beidzot ar aktuālākajiem un svaigākajiem pētījumiem, kurus aplūkojot un izvērtējot iezīmējas arī šì promocijas darba mērḳi un uzdevumi. Autore brīvi un radoši orientējas teorētiskās literatūras plašumos, niansēs pārzina jautājuma izpētes vēsturi. Taču, runājot promocijas darbā aplūkoto jautājumu diskursā, skatījumā uz iepriekšpaveikto dominē monoloǵiskums un šķiet pietrūkst dialoǵiskuma, respektīvi, skaidrāk varēja būt iezīmēta autores attieksme - kas ir viņas autoritātes, kādi uzskati un kāpēc ir vai nav pieņemami. Kopsavelkot pirmo nodaḷu, autore atzīst, ka iepriekšējo pētnieku darbos sniegtie fakti un paustie uzskati noderējuši tālākai pētniecībai. Būtu gribējies šeit skaidrākus un spēcīgākus akcentus. 


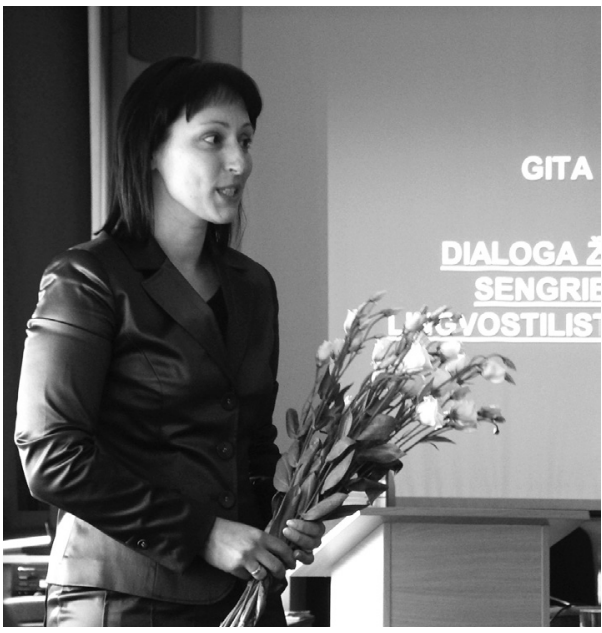

Gita Bērziṇa promocijas darba aizstāvēšanā

Par nozīmīgu pienesumu konkrētā pētījuma veikšanā uzskatāma komunikācijas teorijas noteiktu aspektu apguve un to izmantošana darbā, darba otrajā daḷā sniedzot ieskatu komunikācijas teorijā, pie tam veiksmīgi to sasaistot ar pētāmā materiāla savdabību.

Rakstot par dialogu kā literatūras žanru, autore atsaucas uz krievu filologa S. Averinceva doto Aristoteḷa laikmeta raksturojumu kā garīgu revolūciju un balstās uz atziṇu, ka šajā laikā literatūra sāk sevi apzināties kā literatūru - īpaša veida realitāti (36. lpp.). Vēlāk gan (37. lpp.) minēts, ka Aristoteḷa laikā dažādus literārus žanrus uztver kā dažādas mākslas. Tā tas ir arī pašam Aristotelim, kuram nav vienotas izpratnes par literatūru, pie tam mimēses teoriju, kas viṇa koncepcijā ir literatūras būtìba, viņš saista ar cilvēka tieksmi pēc izziņas un tās sniegto prieku. Tādējādi varbūt šeit ir tikai paši pirmie aizmetṇi literatūrai kā īpaša veida realitātei. Faktiski jau antīkajā pasaulē poētika kā kodificējoša nozare neizveidojas, jo Aristoteḷa Poêtikai īsta turpinājuma nav. Tajā pašā laikā literatūras sevis apzināšanos varam pamanīt arī pirms šì revolucionārā laika jau, piemēram, Hēsioda darbos.

Pētījums aptver 6 gadsimtus grieḳu literatūras un valodas vēsturē, un, kaut arī šos sešus gadsimtus pārstāv neliela autoru kopa, skaidrs, ka ir nepieciešama tekstu atlase konkrētajam pētniecības darbam. Darba ievadā atrunāta pētāmo dialogu atlase. Darbā vērojama rūpīga un pamatīga iedziḷināšanās dialogu tekstos, veiksmīgi caur lingvistisko raksturojumu atklājot žanriskās savdabības. Pētnieciskā pieeja ir konsekventa 
un mērḳtiecīga, katra izvēlētā aspekta gaismā raksturojot triju autoru Platona, Ksenofonta, Lūkiāna - dialogus un katras nodaḷas noslēgumā sniedzot arī kopsavilkumu par aplūkoto jautājumu.

Kopumā darbs gan savā iecerē, gan realizācijā vērtējams kā būtisks pienesums latviešu klasiskajai filologijai un humanitārajai pētniecībai kopumā ar potenciālām starptautiskas rezonanses iespējām, par ko liecina jau darba tapšanas gaitā veiktā pētījuma aprobācija pārrobežu konferencēs un publikācijās."

\section{STUDIJU PAMATS RĪGĀ, DOKTORA GRĀDS ZVIEDRIJ Ā: SANITAS BALODES PROMOCIJAS DARBS VERBS OF MOTION WITH DIRECTIONAL PREPOSITIONS AND PREFIXES IN XENOPHON'S "ANABASIS" (Kustības verbi ar virziena prievārdiem un priedēkliem Ksenofonta "Anabāze"}

Latvijas Universitātes (LU) klasiskā filologa pamatizglìtība ḷauj veiksmīgi turpināt studijas ārvalstīs: Sanita Balode pēc bakalaura studijām Rīgā gan maǵistra, gan doktora grādu ieguvusi Lundas Universitātē Zviedrijā. Viṇas promocijas darbs tika prezentēts un veiksmīgi aizstāvēts minētajā Universitātē 2011. gada septembrī.

Darba zinātniskie vadītāji ir Lundas Universitātes mācībspēki, sengrieḳu valodas speciālisti Jerkers Blumkvists un Karina Blumkviste.

Interesanti, ka promocijas darba aizstāvēšana Zviedrijā atšḳiras no mūsu pieredzes, pirmkārt, ar to, ka disertants iesniedz savu pètījumu jau kā gatavu publikāciju-monogrāfiju. Otrkārt, pati procedūra paredz, ka oponents ir tikai viens (S. Balodes gadījumā šis pienākums tika uzticēts LU Klasiskās filologijas katedras profesorei Ilzei Rūmniecei), bet promocijas komisija triju locekḷu sastāvā pēc oponenta un disertanta prezentācijas un diskusijas noklausiš̌anās balso par vai pret doktora grāda pieškiiršanu monogrāfijas autoram.

Turpmāk lasāma oponenta runa, iebildes un jautājumi, izvērtējot S. Balodes grāmatu Verbs of motion with directional prepositions and prefixes in Xenophon's Anabasis (In: Studia Graeca et Latina Lundensia 17, Centre for Languages and Literature, Lund University, 2011, xvi+220 pp.).

SPEECH OF THE OPPONENT - PROFESSOR ILZE RŪMNIECE (Oponentes profesores Ilzes Rūmnieces runa angḷ valodā)

Honourable Chair, honourable respondent, honourable supervisor of Sanita Balode's research, dear colleagues, ladies and gentlemen, 
Let me first thank you for the invitation to participate in the evaluation of Sanita Balode's research as a member of a highly distinguished examining committee and in the presence of this scholarly and interested audience. I feel very honoured to be given this opportunity. I believe you will understand my wish to express here my pleasure that Sanita Balode is presenting her achievement in science today, at Lund University, particularly because she began her studies at the Classical Philology programme of the University of Latvia, which is also my place of work.

And now, about the Dissertation that is evaluated today.

I wish to thank the respondent for the overall content and treatment of the basic conceptual standpoints, highlighting the essential issues and commenting upon individual details.

I would like to offer my point of view concerning the Dissertation in question; at the same time I shall also present my evaluative comments, inviting the respondent to respond to them with an explanation or clarification of her viewpoint.

\section{General impression:}

Compositionally, the Dissertation is purposefully developed and clearly and transparently divided into sections of the analysis of the material, which is easy to read. Rich footnotes (a total of 452 throughout the work) well expand the body of the material and ideas in a wellgrounded manner.

From the perspective of the content, I find the work compact; in my view, there is nothing superfluous there, and this is quite a positive feature.

I believe that the linguistic and - where appropriate - lexically-semantic and contextual analyses are done scrupulously and are generally accurate. Results of the research work are summarised in two levels of conclusions - separately for each chapter and in the final conclusions.

That the statistical method occupies an important place in the work is demonstrated by 18 different tables, which undoubtedly provide visual support for the ideas expressed and ensure the objective status of the research results.

Permit me to briefly dwell on the principal parts of the Dissertation.

First, the Introduction of the Dissertation:

In it the author has developed five points, which comply with the traditional basic requirements for a philological study. 
The aim of the study can be found in at least three places in the text of the Dissertation, even if slightly differently worded. In my opinion, this is the most precise wording (I quote):

The Dissertation compares different prepositions and verbal prefixes denoting direction in Ancient Greek (the source text is Xenophon's Anabasis). The author of the Dissertation also promises that there will be a treatment of (I quote): how the usage of prepositions differs from that of prefixes when they denote a concrete motion in space, what reasons lie behind their usage, and how various directional elements of source, path and goal differ from each other.

The reader and the evaluator are aided by the author's indication of the premises that had played a stimulating role at the initial stages of research:

- the use of the prefix or the preposition might depend on (I quote): how the moving entity is moving with respect to the landmark, and the characteristics of the landmark itself (1);

- another assumption prior to the research process (I quote): the prefix determines whether the verbal action denotes the starting point, the path, or the end point of a motion (3);

- upon studying the three abovementioned semantic fields, the author of the Dissertation proposes to find out (I quote): for which of these semantic fields there is the greatest range of expressions, in the form of different prefixes and prepositions. In this regard, based on analogous studies of other texts, the author proposes the hypothesis of the Dissertation that the most numerous group could be the one with the verbs of the end point of a motion or of goal (the latter is the term used in the Dissertation).

On the issue of the choice of the material: the author has given a very detailed commentary of this aspect by initially determining the group of lexemes that she calls 'base verbs', that is, non-prefixed verbs; then she proceeds to indicate that the main factor in the selection of linguistic elements for analysis is frequency (9), which is a matter-of-course factor in research of this kind; likewise, the intent not to involve cases of metaphorical usage (11) of the verb is also objectively understandable.

Slightly confusing is the fact that the description of the material under analysis includes a number of various exceptions, or exceptions of exceptions. In other words, they constitute elements which will eventually be treated, although they represent the group that was excluded from the analysis (on page 16). 
Novelty of the theme. The chapter "Previous Studies" contains the information on the Dissertation's scientific contribution to the study of the Greek language and certain elements of the given text: the theme appears to have been little if sporadically reflected in scientific publications. Besides, Luraghi's "On the Meaning of Prepositions and Cases", one of the essential works that deals with the theme in question, does not treat Xenophon's texts at all.

The list of bibliography used in the Dissertation contains 60 (sixty) entries (including the lexicographical material and publications of Xenophon's texts): this positively demonstrates the positioning of Sanita Balode's work as new research in the context of the publications to date.

The particular novelty in Dissertation by Sanita Balode is the comparative analysis of the functions of prefixes and prepositions with the verbs of motion, both in terms of semantics and comparative frequency.

It is commendable that in the domain of terminology the author has chosen a creative approach to the existing theoretical standpoints concerning the expression of motion event in various studies - she has created her own system of terms, which also integrates, with certain modification, the terminology used by Talmy and Fillmore for the field in question. The author also introduces new terms, for example, landmark (instead of Talmy's "ground"). An exhaustive explanation of the term 'landmark' (together with a table of examples - Table 4) convincingly proves the necessity of introducing a more precise/specific designation than 'ground' for the analysis of the text under analysis in the Dissertation.

The author of the Dissertation develops the concept of 'landmark' on two dimensions, which characterize the object according to the specific topic, that is, animate/inanimate and linear/planar/voluminar. This approach is helpful in analysing the nuanced meanings of prefixes of motion verbs and the corresponding prepositions.

The chapter on terminology also includes a laconic but meticulous explanation of the use of the given set of terms within the framework of this Dissertation.

I am of the opinion that the chapter on method dwells rather on the basic principles of analysis and gives a description of the procedure and stages of the study. However, from this description the reader can conclude that the author will use in her work the statistical method as well as the method of comparative and contextual analysis. For research of 
this kind, these methods can be endorsed, and they have proved to have been fruitful and convincing.

Permit me to proceed to the basic part of the Dissertation, or the research section. The text here has a simple and lucid structure according to the three types of direction of motion that the author has selected and that are expressed by the base verbs: source, path and goal; each of these three chapters presents an analysis of prefixes and prepositional phrases, and the summary of results is given at the end of each chapter. The goal here has been a comparison of functionality of the prefixes and the corresponding prepositions. (I shall raise some of my objections concerning the structure of the work in the question-answer session.)

In general, the author's idea in the basic analytical part is clear and well proved with full-sentence examples from the original text under analysis and their translation; the footnote commentaries provide references to all Xenophon's contexts that relate to the described meaning but are left outside the frame of the in-depth analysis.

Footnotes also include separate additional commentaries from theoretical sources or, according to the author, essential developments of ideas in relation to the basic part of the Dissertation. All of the above demonstrates the author's maturity in producing a philological treatise for the reader's assessment.

The presence of the statistical material (I have already mentioned 18 data tables) is an integral part of the work, which presents the results of the analysis in a visually convincing way and highlights the basic identified trends. In my opinion, this material is processed and presented in a graphically lucid and informatively accurate manner.

\section{The results or the analysis expounded in this Dissertation:}

In my opinion, the most relevant gains of the thesis are:

- indicated factors that influence the choice of directional elements (10 such factors are mentioned in the chapter General summary and conclusions);

- indicated differences between prefixes and prepositions expressing the directional relations in the Greek phrase (for instance, in the language of Xenophon) (I-IV, 211./212.); here let me additionally quote the author: The data show that our initial hypothesis has proved to be true, and that prefixes are more likely than prepositions to retain their basic meanings;

- the base verbs and expressions of path and goal are represented by more directional elements than those of source, in other words: 
there is a comparatively small number of prefixes and prepositions of source;

- the directional elements of all three relations (source, path, goal) specify some important elements, such as:

- whether the landmark is animate or inanimate,

- $\quad$ intensity of the verbal action (within the group of the directional elements of source $-e k$ ),

- the temporal relation (element of goal - pro-),

- the manner of action/motion (mostly a hostile motion) - this is a case of the directional elements of goal.

The base verbs of motion examined in Xenophon's text reveal a significant fact: a relatively small number of verbs of source and goal, compared with a considerably greater number of verbs of path (216).

I shall now permit myself to mention some critical observations when evaluating S. Balode's Dissertation.

1. Was the refusal of using several verbs as potentially important objects of analysis connected with the wish to reach objectively more solid results or with unwillingness to end the study with unduly extensive (and diffuse) results by involving individual nuances and non-standard cases? The examples in this regard could be the verbs ballo and pherō: they are said to have been used in Xenophon's text metaphorically a number of times; yet, in passages in which they denote direction... they do not amount to fifty, the necessary number of units for the group to be included in the study. I would like to know by what number these verbs of motion fell short of fifty (to be included in the material under study). Moreover, we can consider the fact that the smallest admissible units under analysis in the group of base verbs of source of motion is only 30 (thirty). In any case, the prospective user of the facts and results of the Dissertation would be better informed if the verbs that have not been included in the study were mentioned in an aggregate form (in a table, perhaps?) rather than scattered in the Dissertation text among the commentaries.

2. On evaluating the analysis of base verbs and their prefixed meanings in the Dissertation text, the question arises: how much of novelty contribution has the author made in the treatment and identification of semantics if compared to the material of the existing lexicographical material? I did not find any mention of this in the Dissertation, so it would be interesting to hear now the author's view and assessment of 
her novelty contribution in the field of defining the semantics of the verbs more precisely.

3. Considering a certain prefixation to a given motion verb and the understanding of its meaning, or the interpretation of prepositional phrases in this Dissertation - has the respondent taken into account the possibility that part of the contexts under analysis demonstrate the use peculiar to a definite author (Xenophon) and his time or even the environment? In other words, to what extent could the results of the analysis of Xenophon's motion verbs be used as a general comparison indicator for at least the archaic and classical periods in the development of the Greek language? It appears that this parameter might prove essential for the reader and user of the Dissertation.

4. The author has more than once pointed out that individual prefixes (for example, ek-, p. 58) can additionally express intensity of verbal action. Is it the given prefix that is responsible for this nuance in relation with a motion verb of a definite meaning, or is it contextually determined?

5. In general, I appreciate the Dissertation author's sequential train of thought and her wish to conclude each stage of the study with a corresponding summary. However, one cannot but notice a rather ramified accounting system when summaries of different levels break up the narration and exposes the reader to certain repetitiousness. Thus, for example, on pages 32-34 there are three Summaries, separated by the same title, while only one of them (on page 32) has been given in the Table of Contents. To chose the abovementioned chapter 2.1.3 Function with verbs of path, one can see that it is concluded with subchapter 2.1.3.4 Summary. May I ask the respondent to comment on the necessity to develop within a chapter three additional 'inner' summaries. How does the analyser and the reader benefit from this, since at times the summaries follow each other in such density that there is practically no text in between to summarise? Besides, the subchapters of the chapters are concluded with a section Summary and conclusions. Aren't the summaries a little too frequent? (I'd rather follow the famous Greek saying: méden agan...)

Speaking both of the research work and the course of the disputation, my impression is that the author of the Dissertation merits appreciation - conferment of the doctor's degree. 


\section{IN MEMORIAM}

INĀRA ĶEMERE (23.04.1939.-04.09.2013.)

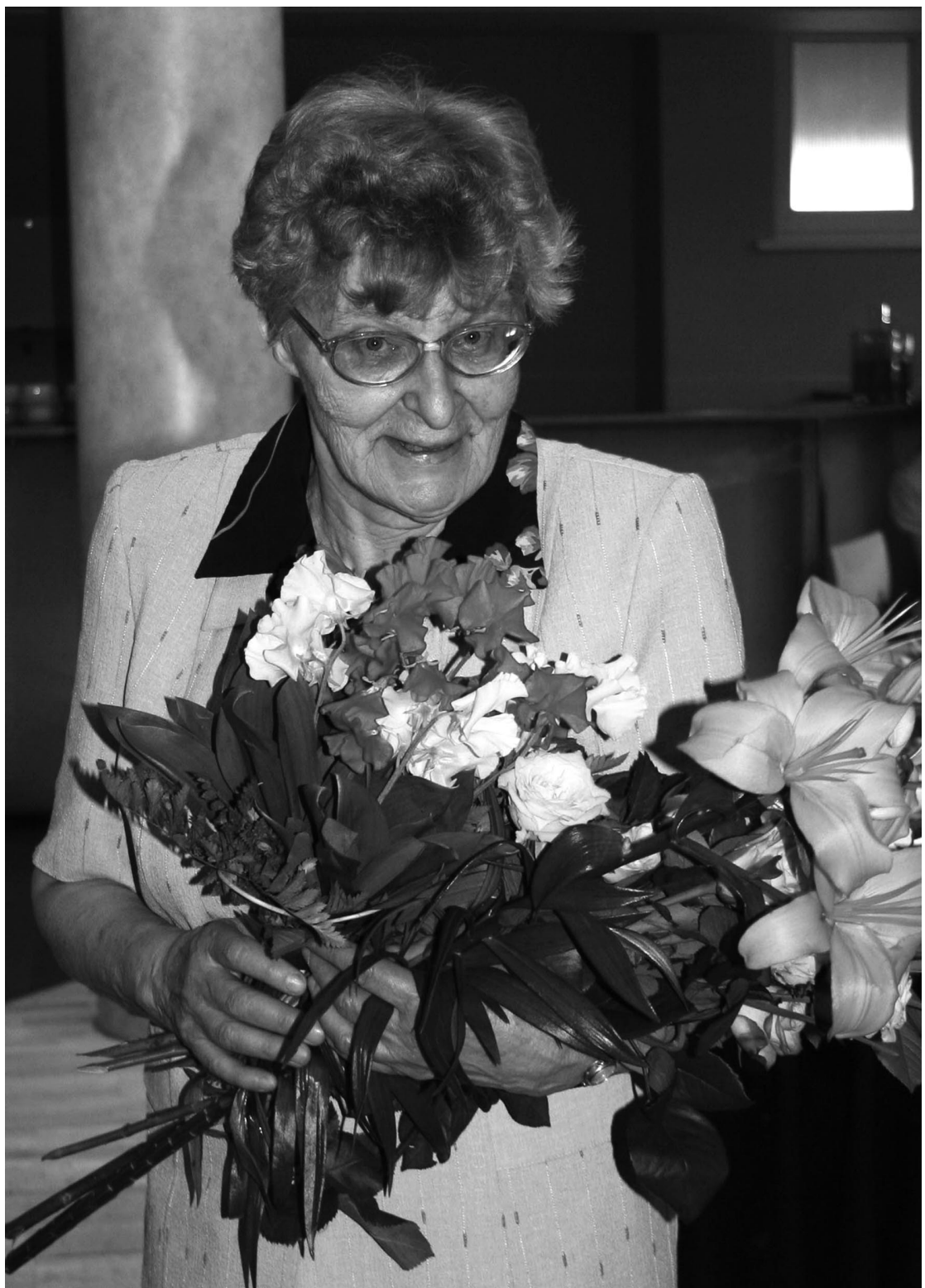

CC 
Sors tua mortalis; non est mortale, quod optas...

(Ovidius Met., II, 56)

2013. gada 4. septembrī aizsaulē aizgāja izcilā klasiskās filologiijas speciāliste un lieliskā pasniedzēja Ināra Ķemere. Untumainais liktenis lēmis pārlieku nežēlīgi, Latvijas filologu saimei un Latvijas kultūrai atņemot erudītu, ar fundamentālām zināšanām apveltītu personību, kuras trūkumu skaudri izjutīs ikviens, ar kuru viṇa līdz pēdējam brīdim dāsni dalījās savās zināšanās un ar antīko pasauli saistīto lietu izpratnē.

Ināra Ķemere savu daudzpusīgo personību pilnveidoja, studējot baltu filologiju Latvijas Universitātē (LU) un apgūstot klavierspēli Latvijas konservatorijā, bet par viņas mūža mīlestību kḷuva klasiskā filoloğija, kuras pamati tika likti L,eṇingradas Universitātē un turpmāk zināšanas papildinātas nerimtīgi līdz pēdējai mūža dienai.

Ilgus gadus Ināra Ķemere bija LU Filologijas fakultātes klasiskās filoloǵijas pasniedzēja. Viņas plašā erudīcija un personības valdzinājums rosināja studentu interesi apgūt latīnu un sengrieḳu valodu un seno grieḳu un romiešu autoru atstāto literāro mantojumu jau tajā laikā, kad LU vēl nebija atjaunotas klasiskās filologijas bakalaura un maǵistra studiju programmas. Arī vēlāk Ināra Ķemere iedvesmoja un aizrāva gan visus topošos klasiskos filologus, gan ikvienu interesentu, kuram laimējās baudīt viṇas plašās valodu zināšanas un dziḷlo antīkās kultūras izpratni.

Nenovērtējams ir arī Ināras Ķemeres ieguldījums Latvijas sabiedrības iepazīstināšanā ar antīkās pasaules kultūras vērtībām, gan rakstot dažādiem izdevumiem, tostarp nozīmīgām Latvijā izdotām enciklopēdijām, gan strādājot par konsultanti Latvijas Rakstnieku savienībā, gan tulkojot no senajām valodām.

Bez Ināras Ķemeres artavas nebūtu varējusi pastāvēt unikālā pagātnes domātāju darbu sērija Avots, kur viṇa vairākiem izdevumiem bijusi priekšvārdu autore vai līdzautore, tulkotāja, kā arī veicinājusi sengrieķu un latīṇu îpašvārdu pareizu atveidi latviešu valodā. Šajā sērijā lieliskā Ināras Ķemeres tulkojumā iznācis Aristoteḷa traktāts Nikomaha ètika un Marka Aurēlija traktāts Pašam sev. Ināra Ķemere sadarbojās arī ar Latvijas teātriem, tulkojot Sofokla un Aristofana lugas. Bet 16. gs. Rīgas 
humānista Bazilija Plīnija latīniski sacerētā darba Slavas dziesma daudzinātajai pilsētai Rīgai parindeṇu tulkojums ḷāva dzejniekiem atdzejot šo poēmu latviešu, vācu, krievu un angḷ valodā, tā padarot to pieejamu plašam lasītāju lokam.

Ināra Ķemere piedalījusies arī senāk latviešu valodā izdoto antīko tekstu rediǵěšanā, piemēram, redaktores darbs ar Aristoteḷa traktāta Poētika jaunāko izdevumu palīdzēja tam iegūt kvalitatīvu spozmi.

Pēdējos gados Ināra Ķemere visu savu laiku un neizsīkstošo enerǵiju veltija, aktīvi līdzdarbojoties jaunā Bībeles latviskojuma tapšanā un veidojot apjomīgas sengrieķu-latviešu valodas vārdnīcas pirmizdevumu, kas būtu ne tikai neatsverams palīgs topošo klasisko filologu studijās, bet arī nenovērtējams ieguldījums visas Latvijas kultūrā. Diemžēl dzīves pavediens, tik pēkšn,i aprāvies, atstāja līdz galam nepabeigtu šo viņas loloto darbu, kuram nu lemts kḷut par mantojumu, ko pabeigt jāspēj sekotājiem.

Seno romiešu domātājs Seneka, runājot par daudziem dižiem antīkās pasaules prātiem, kuri veikuši lielus darbus, bet kaut kāda iemesla dēl nav paguvuši tos novest līdz galam, aicina izturēties pret šādiem dižgariem ar dziḷu cieṇu un godāt tos līdzīgi dieviem. Tad nu lai arì mēs dziḷā cieņā un pateicībā noliecam galvu, pieminot Ināru Ķemeri, un vēlamies, kaut spētu būt tik viedi, ka, dzirdot viņas vārdu, gūstam iedvesmu un spirdzinājumu, līdzīgi kā Seneka, kurš abus Markus Katonus, Lēliju Gudro, Sokratu un Platonu, Zēnonu un Kleantu uzṇēma savā dvēselē ar visdziḷāko cieṇu, tos bijīgi godāja un, dzirdot šos dižos vārdus, vienmēr atspirga.

Ināra Ķemere ar savām zināšanām un erudīciju, augsto atbildības izjūtu un pienākuma apziṇu, labestību un sirds gudrību vienmēr paliks to cilvēku sirdīs un atmiņās, kuri viṇu pazina un kurus iedvesmo darbiem viṇai nozīmīgās garīgās un cilvēciskās vērtības.

Brigita Cīrule Gita Bērziña 


\section{INĀRU ĶEMERI ATCEROTIES}

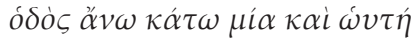

(Hērakleits, DK B60)

\section{Dens Dimiņš}

Pasniedzējai - mēs, studenti, saucām viṇu tieši tā, kaut būtu varējuši saukt arī par Skolotāju vai vēl pagodinošāk, ko gan neuzdrīkstējāmies, jo viṇa kā cilvēks, kam svešas visādas āriškīibas un titulu būšanas, to nebūtu pieḷāvusi, - noteikti nepatiktu sentimentāli, patosaini, slavinoši, liekvārdīgi nekrologi. Daudz ko var un vajag pateikt vienkāršos vārdos, un skaidrība un stilistiska pieticība bija tas, pie kā viṇa mani radināja, būdama bakalaura un maǵistra darba zinātniskā vadītāja. $\mathrm{Nu}$ jau paši darbi ir piemirsušies, bet mācību procesā iegūtais nav zudis - tas mani ir bagātinājis un līdz ar to darījis arī labāku un laimīgāku. Vēsts par Pasniedzējas nāvi mani sasniedza aplam tālajā Ultima Thule, tāpēc nākas atvadīties domās un atmiņās. Atceros vienu pēcpusdienu viṇas Mežaparka dzīvoklī pagājušovasar: neiztrūkstošā kafija, zemenes un viegla cigarešu smarža...

Pasniedzējai Ḳemerei nav vajadzīgi nekādi slavinājumi, jo viṇas darbi runā skaidru valodu - ar publikāciju klāstu ikviens var iepazīties LNB katalogā, bet daudz kas paliek aiz kadra - dāsni sniegtās konsultācijas un ilggadējais akadēmiskais gājums, par ko glabā atmiṇas neskaitāmi studenti. Jācer, ka drīzumā iznāks arī viņas Magnum Opus, sengrieķu-latviešu vārdnīca, un tas mums visiem kalpos par mierinājumu un atgādinājumu tam, ko var paveikt viens darbīgs un možs cilvēks. Mūsu klasiskās filologijijas studentu kurss - atḷaušos runāt ne vien savā, bet visu 1998. gada absolventu vārdā - no viṇas ieguva l,oti daudz: ne tikai zināšanas par antīko literatūru, Senās Griekijas un Romas vēsturi, grieķu valodas sintaksi, ne tikai komentētus Isokrata, Homēra, Sofokla un Horācija lasījumus oriǵinālā, bet arī visa šā mantojuma okeānisko sajūtu, tā ārkārtīgās cilvēcības, komisma, traǵisma, ironijas apjautu. Mēs sadzirdējām homēriskus smieklus, kuṛos ieskanējās arī pa melanholiskai notij, - to visu viņa mums uzbūra, palaikam taktiski piesedzot mūsu niecību šìs bagātības priekšā un dažlabu arī pelnīti pavelkot uz zoba par paviršību, aprobežotību un zināšanu nesaturētspēju. Bet nekad viṇa neatṇēma mums ticību pašu izaugsmei un varēšanai. Daudzas pērles, ko Pasniedzēja ripināt ripināja mūsu silē, tolaik palika nenovērtētas, bet 
tam nav nozīmes - galvenais, ka viṇa parādīja mums ceḷu uz klasiskās senatnes pasauli, kuru ikkatrs esam mērojuši, ciktāl spējuši un gribējuši. Pasniedzēja ir aizgājusi, bet mēs šo ceḷu turpinām. Paldies viṇai par to.

\section{Māra Grudule}

Ināra Ķemere mums mācīja senās valodas un ir starp pasniedzējiem, kas paliek atmiṇā nevis vienas īpaši spilgtas situācijas dēl, kā tas dažkārt mēdz gadīties, bet kā tēls ar īpatnēju mīmiku un biezām acenēm, kā cilvēks, aiz kura slēpās dziḷas zināšanas un lieliska humora izjūta. Pirms pāris gadiem janvārī mūsu ceḷi krustojās vēlreiz, kad Ināra Ḳemere man piepalīdzēja Smiltenes mācītāja Jakoba Langes latīnisko dienasgrāmatu tulkojumā, tostarp ar Vergilija Eneidu (X. 467-469), kuru draudzes gans licis savu memuāru otrās daḷas ievadā: Katram ir nolikta [vinga] diena: dzīves laiks ir ìss un neatgūstams, bet slavu vairot ar darbiem, tas ir krietnības uzdevums.

\section{Ojārs Lāms}

Ināras Ķemeres bērēs, klausoties grieḳu mūzikas skaṇās, tik reti dzirdamās mūspusē un bērēs tik neierastās, bet ar savu vibrējošo dzīvīgumu tik ķemeriskās un aiziešanas/palikšanas dialektiku paudošās, domas, protams, plivinājās līdzīgi apjukušiem putniem, kas vēlas izlauzties no nolemtības, vienlaikus pie atmiṇu drumslām tveroties kā pie iluzoriem zariem. Un gluži neobligāta un varbūt pat nevajadzīga atskārta - šoruden pagāja trīsdesmit gadi, kopš pazīstu Ināru Ķemeri - tāds kā Trojas cikls. Un tad vēl atskārta, ka toreiz viṇa bija jaunāka nekā es tagad. Mazsvarīgi, bet atsauc atmiņā Homēru - Ķemerei un nu arī man tik mīlo - viṇa atziṇu par to, ka cilvēkiem liktenis kā lapām mežā - tā mēs maināmies un zūdam. Ķemere vienmēr likās kā nerimtīga darba bite, nē - drīzāk kamene, sava jaudīguma pēc. Profesionālajā jomā to var nosaukt par laimi - piedzīvot Ināras Ķemeres aicinājumu sadarboties un kopā strādāt pie jauna Aristoteḷa Poètikas izdevuma latviešu valodā. Cieņa pret Ģiezena mantojumu un pašas pieticība noteica to, ka jaunais izdevums tika izdots kā redakcija, bet Ķemere izgāja tekstu vārdu pa vārdam, man nācās ik pa laikam krietni atpalikt. Atceros jau kopdarba beigās kādu atvasaras dienu piesaulītē viṇas dārzā pie mazas puḳu dobītes - Ķemere kā sargs noliekusies ar lejakannu pār mazo un trauslo ziedu, kuru drīz skars salna. Tā es viṇu redzu noliekošus un palikušu rūpēs par Valodu. 


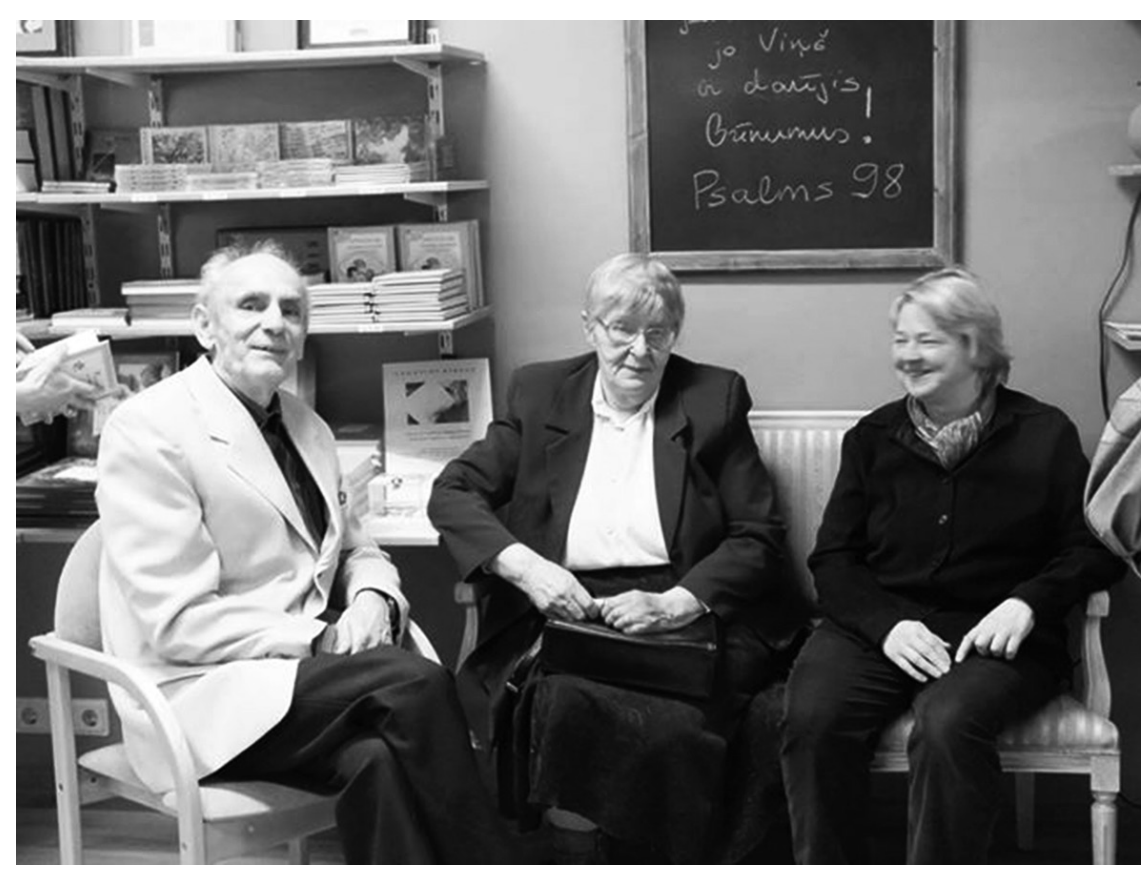

Ināra Ķemere ar kolēgiem Latvijas Bībeles biedrībā 2013. gada pavasarī

\section{Ilze Rūmniece}

Ināru Ķemeri sastapu Klasiskās filolog̣ijas katedrā, kad sāku darbu kā pasniedzēja LU Filoloǵijas fakultātē pēc klasiskās filoloǵijas studiju gadiem Maskavas Valsts universitātē. Biju homo novus - svešiniece jau esošajiem un ilglaicīgajiem katedras cilvēkiem, arī fakultātē vispār, jo nebiju studējusi te.

Uzreiz bija samanāms, ka Inārai Ķemerei ir īpaša vieta un loma gan katedrā, gan citu fakultātes kolēğu un arī studentu vērtējumā. Skaidrs, ka viņas pamatīgo zināšanu, asās domas un labās humora izjūtas un to pasniegšanas dēḷ. Izjutu cieņu, redzot, ka visi ar viņu arvien visvairāk konsultējās dažādos mūsu klasiskās jomas problēmjautājumos. Tikai ar laiku un pārsteigumu uzzināju, ka Inārai Ḳemerei nav doktora grāda pēc viņas zinību bagāžas spriežot, tas bija paradoksāli. Visi zina, ka nereti viņa atmeta: papīri nebūt neesot galvenais.

Divas domas no Ināras Ḳemeres esmu aizguvusi kā visnotal vērtīgas. Pirmā ir viṇas (protams, ironijpilnais, bet arī reālais) ieteikums 
eksāmenos grūtos jautājumus par seno valodu vārdformām formulēt pēc parauga „Tas taču ir daudzskaiț̣a ablatīvs, vai ne?” Tad, kā viṇa teica, arī atbildes būs labas un pareizas.

Otra doma saistīta ar attieksmi pret klasiskajām valodām to apguves procesā. Katedrā nereti tika pārrunāts, kā veiksmīgāk pasniegt šos priekšmetus. Tradicionālais viedoklis bija: rādām studentiem tabulas un paradigmas, stāstot, cik viss valodā ir strukturēti un līdz ar to patiesībā vienkārši. Inārai Ķemerei arvien bija pretējs viedoklis: jāizceḷ un jāatgādina, ka latīṇu un sengrieķu valodas apgūšana ir grūts, pat sarežğīts un ilglaicīgs process; nekas te nav vienkārši vai gūstams bez pūlēm, tas jāzina un jāpien,em.

Pēdējos gados arvien vairāk domāju par šo viedokli. Un, kad reizēm dzirdu sevi sakām nodarbībā - „redzat, te pēc analoǵijas, tas vienkārši", Ināras Ķemeres dēḷ iedomājos sevi aiz muguras turam sakrustotus pirkstus...

Sit tibi... levis 


\title{
A B S O LV E N T I
}

\author{
LATVIJAS UNIVERSIT ĀTES \\ KLASISKĀS FILOLOG̣IJAS STUDIJU PROGRAMMĀS
}

ALUMNI IN CLASSICAL PHILOLOGY STUDY

PROGRAMMES AT THE UNIVERSITY OF LATVIA

2009-2012

Bakalauri / Bachelors of Arts, 2009

\section{Bodniece Līva}

Ovidija Pēnelope: tēla poētika

Ovid's Penelope: Poetics of the Character

\section{Freidenfelde Laura}

Kirkes pārvērtības Ovidija Metamorfozēs

Circe's Transformations in Ovid's Metamorphoses

\section{Glūdiņa Agate}

Antitèze Platona agrīnajos dialogos

Antithesis in Plato's Early Dialogues

\section{Laksa Laura}

Cildenais Aristofana komēdijās

The Noble in Aristophanes' Comedies

5. Lisovska-Gabrāne Marina

Komisms Kallimaha himnās

Comicality in Callimachus' Hymns

6. Seḷeznova Alise

Retoriskais jautājums Cicerona Runās pret Katilīnu

Rhetorical Question in Cicero's The Catilinarian Orations

7. Šaripova Vija

Ethopoiia Līsija runās

Ethopoiia in Lysias' Speeches 


\section{Maǵistri / Masters of Arts, 2009}

\section{Gorneva Ilona}

Slavinājums un nopēlums Menandra retorikā

Praise and Condemnation in Menander's Rhetoric

\section{Kiṇkere Zane}

Latīnu sentences stilistiskā uzbūve (Plīnija epistulārie teksti)

Stylistic Structure of the Latin Maxim (Pliny's Epistolary Texts)

\section{3. Šimkēviča Ingūna}

Emocionāli ekspresīvā leksika Sofokla traǵēdijās

Emotional Expressive Vocabulary in Sophocles' Tragedies

\section{Tangaličeva Estere}

Conscientia Cicerona tekstos

Conscientia in Cicero's Texts

5. Vanaga Ilze

16. gadsimta Rīgas humānistu enkomiskā dzeja

Encomia of Riga Humanists of the 16th Century

\section{Bakalauri / Bachelors of Arts, 2010}

\section{Apse Livva}

Varonis $\bar{l} l i a d \bar{a}$ : tipoloǵiskais aspekts

Hero in Iliad: Typological Perspective

\section{Biseniece Ilze}

Runātāja pašpozicionējums Līsija tiesu runās

Speaker's Self-Positioning in Lysias' Judicial Speeches

\section{3. Čerņaka Darja}

Antitēze „mēs/grieki" un „vinii/barbari” Hērodota Vēsturē

Antithesis "We/Greeks" and "They/Barbarians" in Herodotus' Histories

\section{Fībiga Ieva}

Eleos sengrieḳu traǵēeijās kompozīcijā un valodā

Eleos in the Composition and Language of Greek Tragedies

\section{Jirgensone Santa}

Kompozītie epiteti kā komisma elementi Aristofana komēdijās

Composite Epithets as an Element of Comicality in Aristophanes' Comedies 


\section{Korotkaja Inna}

Autors/vēstītājs un adresāts/mērḳauditorija Lukrēcija poēmā Par lietu dabu

Author/Narrator and Addressee/Target Audience in Lucretius' Poem On the Nature of Things

\section{Laizāns Mārtin̄̌s}

Gnomes Aristoteḷa Rētorikā (1. grāmatā)

Gnomes in Aristotle's Rhetoric (Book I)

\section{Meldere Indra}

Divkauju tipoloǵija antīkajā episkajā tekstā Homēra Īliadā un Vergilija Eneidā

Combat Typology in Ancient Epic (Homer's Iliad and Vergil's Aeneid)

9. Melngaile Alīna

Ethos Cicerona runās In Pisonem un Pro Milone

Ethos in Cicero's Speeches Against Piso and In Defence of Milo

10. Poga Aija

Pietas Vergilija Eneidā

Pietas in Vergil's Aeneid

\section{1. Šantarina Inna}

Pathos Teokrita dzejā

Pathos in Theocritus' Poetry

\section{Maǵistri / Masters of Arts, 2010}

\section{Bekere Ingrīda}

Parodija Ovidija mīlas elēgijās

Parody in Ovid's Love Elegies

\section{Eglīte Ilze}

Antitēzes formas un satura diferencējums Plauta komēdiju valodā Differentiation of the Form and Content of Antithesis in the Language of Plautus' Comedies

\section{Konins Igors}

Ethopoiia pseidovēsturiskajā epistologrāfijā (Temistokla cikls)

Ethopoiia in Pseudohistorical Epistolography (Themistocles' Cycle)

\section{Uzula Aija}

Homēra un Plūtarha tekstu funkcionalitāte K. Kavafja dzejā Functionality of Homer's and Plutarch's Texts in C. Cavafy's Poetry 


\section{Zaičenoka Ieva}

Komisms Petronija Satirikonā

Comicality in Petronius' Satiricon

\section{Bakalauri / Bachelors of Arts, 2011}

\section{Bogomolova Juliana}

"Šḳidruma" leksikas funkcionalitāte Horācija odās

Functionality of "Liquid" Lexis in Horace's Odes

\section{Bujāne Anete}

Draudzības koncepts Katulla dzejā

The Concept of Friendship in Catullus' Poetry

\section{Davidenkova Olga}

Netikumi Marciāla dzejā (leksiski semantikais aspekts)

Vices in Martial's Poetry

\section{Dzene Kristīne}

Salīdzinājums un tā funkcijas Ovidija elēgijās

Simile and its Functions in Ovid's Elegies

\section{Fogele Diāna}

Perifrāze Vergilija Eneidā

Periphrasis in Vergil's Aeneis

\section{Jemeljanova Kristina}

Anakreonta dzejas tradīcija un tās recepcija anakreontiskajā dzejā

The Tradition of Anacreon's Poetry and its Reception in

Anacreontian Poetry

\section{Leitholde Aiga}

Arete Aristoteḷa Rētorikā

Arete in Aristotle's Rhetoric

\section{Rubinrota Ksenija}

Analog̣ija Ksenofonta sacerējumā Atminas par Sokratu

Analogies in Memorabilia by Xenophon

\section{Sadovska Evija}

Pathos Teognīda elēgijās

Pathos in Theognis' Elegies

\section{Spieḳe Daila}

Leksika kā komisma avots Lūkiāna satīriskajā dialogā

Lexis as a Source of Comicality in Lucian's Satirical Dialogue

$\frac{\text { CCX }}{210}$


11. Utkina Alisa

Varas dimensija Homēra eposā Îliada

Dimension of Power in Homer's Iliad

\section{Zavileiska Sandra}

Mirušo valstîba antīkajos tekstos

The Land of the Dead in Classical Texts

\section{Maǵistri / Masters of Arts, 2011}

\section{Bodniece Lìva}

Vārdu figūras Katulla īsajos dzejoḷos

Figures of Speech in Catullus' Short Poems

2. Freidenfelde Laura

Simposija satura un formas tradīcija Plūtarha Septinu gudro dzīrēs Traditional Aspects of Symposium Content and Form in Plutarch's Banquet of the Seven Wise Men

\section{Heimane Ieva}

Epiteta funkcionāli stilistiskā loma Ovidija Metamorfozēs

Functional Stylistic Role of Epithet in Ovid's Metamorphoses

\section{L,aksa Laura}

Hiperbolas veidošanas principi atiskās traḡēdijas un komēdijas valodā: salīdzinošais aspekts

Principles of Hyperbole Formation in the Language of Attic Tragedy and Comedy: Comparative Aspect

\section{Seḷeznova Alise}

Romas impērijas biogrāfiskā proza: personības transformācija Biographical Prose of the Roman Empire: Aspect of Personality Transformation

6. Šaripova Vija

Pathos sengrieķu bēru runās

Pathos in Ancient Greek Funeral Orations

\section{Bakalauri / Bachelors of Arts, 2012}

\section{Boḷšakova Estere}

Dialogs Homēra İliadā

Dialogue in Homer's Iliad 


\section{Ezerkalns Gatis}

Valdnieka kults Ovidija poēmā Fāsti

Ruler Cult in Ovid's poem Fasti

\section{Frolovičeva Valērija}

Vergu valodas iezīmes Plauta komēdijās

Features of the Language of Slaves in Plautus' Comedies

\section{Herings Toms}

Vēstītājs Hēsioda poēmā Darbi un dienas

Narrator in Hesiod's Poem Works and Days

\section{Indulēna Anete}

Epiteti varoṇu raksturojumam Homēra Odisejā

Epithets for Characterizing Heroes in Homer's Odyssey

\section{Kardele Ieva}

Romas dzīves atainojums Horācija dzejā

Description of the Life in Rome in Horace's Poetry

\section{Koḷesnikova Liene}

Dzīru motīvi sengrieķu arhaiskajā dzejā

Banqueting Motifs in Ancient Greek Archaic Poetry

\section{Krakope Madara}

Ira un ultio Senekas traǵēdijās

Ira and Ultio in Senecan Tragedy

9. Permanicka Alise

Tikums un netikums romiešu vēsturiskajā prozā

Virtue and Vice in Roman Historical Prose

10. Prancāne Renāte

Svētbirzes un to funkcijas Ovidija poēmā Fāsti

Sacred Groves and Their Functions in Ovid's Fasti

\section{Prelgauska Rita}

Sievietes Homēra sabiedrībā

Women in Homer's Society

\section{Pričina Līga}

Laika jēdziena apzīmējumi Senekas Vēstulēs Lucīlijam par ètiku

Designations of the Concept of Time in Epistulae Morales ad Lucilium by Seneca

\section{Stopina Santa}

Salīdzinājums Katulla dzejā

Simile in Catullus' Poetry 
14. Šarigins Artis

Retoriskie izsaucieni un retoriskie jautājumi Cicerona Runās pret Katilinu

Rhetorical Exclamations and Rhetorical Questions in Cicero's The Catilinarian Orations

\section{Maǵistri / Masters of Arts, 2012}

\section{Fībiga Ieva}

Metafora sengrieḳu medicīnas tekstos: Galēns

Metaphor in Ancient Greek Medical Texts: Galen

\section{Jirgensone Santa}

Klasiskais periodos Tacita tekstos

Classical Periodos in Tacitus' Texts

3. Melngaile Alīna

Indignatio Juvenāla satirās

Indignatio in Juvenal's Satires

\section{Poga Aija}

Salīdzinājums un tā funkcionālā nozīme Senekas Vēstulēs Lucìlijam par ètiku

Simile and its Functional Meaning in Seneca's Moral Epistles to Lucilius

\section{5. Šantarina Inna}

Leksēmas kardia un nous koinē valodā (Jaunās Derības teksti) Kardia and Nous Lexemes in the Koine Greek Language (The New Testament)

6. Šestovskihs Sergejs

Senekas biogrāfijas agrīnajā itāḷu renesansē

Early Renaissance Biographies of Seneca 


\section{AUTORI}

Gita Bērziṇa - klasiskā filolog̣e, Dr. philol., LU Klasiskās filologiijas katedras docente

Lìva Bodniece - klasiskā filoloğe, Mg. philol., LU Klasiskās filologijas katedras lektore, doktorante

Brigita Cīrule - klasiskā filoloğe, Dr. philol., LU Klasiskās filologiijas katedras docente

Dens Dimiṇš - klasiskais filologs un tulkotājs, Mg. philol., Islandes Universitātes doktorants

Ieva Fībiga - klasiskā filoloǵe, Mg. philol., LU doktorante

Marija Gjannaki - Sorbonnas Universitātes doktore (Francija)

Ilona Gorṇeva - klasiskā filoloğe, Mg. philol., LU Klasiskās filologiijas katedras lektore, doktorante

Igors Konins - klasiskais filologs, Mg. philol., LU absolvents

Brigita Kukjalko - klasiskā filoloǵe, Dr. philol., LU Klasiskās filologijas katedras lektore

Mārtin̄š Laizāns - klasiskais filologs, Bc. philol., LU maǵistrants

Ojārs Lāms - literatūrzinātnieks, klasiskais filologs, Dr. philol., LU Latvistikas un baltistikas nodalas profesors

Lìva Muižniece - filozofe, Dr. phil., LU Filozofijas un sociologijas institūta pētniece, LU Humanitāro zinātṇu fakultātes Klasiskās filologiijas un antropologijas studiju nodaḷas un LU Vēstures un filozofijas fakultātes pasniedzēja

Vita Paparinska - klasiskā filologé, Dr. philol., LU Klasiskās filologijas katedras profesore

Ilze Rūmniece - klasiskā filoloǵe, Dr. philol., LU Klasiskās filologijas katedras profesore

Iveta Skrastina - klasiskā filologe, Mg. philol., LU absolvente

Dace Strelēvica-Ošiņa - valodniece, Dr. philol., LU Latviešu valodas institūta pētniece

Georgijs Teotokis - vēsturnieks, Dr. hist., Fatihas Universitātes docents Eiropas vēsturē (Turcija)

Harijs Tumans - vēsturnieks, Dr. hist., LU Arheologijas un vēstures palīgzinātṇu katedras asociētais profesors 


\section{CONTRIBUTORS}

Gita Bērziña - classical philologist, Dr. philol., associated professor of Chair of Classical Philology, University of Latvia

Liva Bodniece - classical philologist, Mag. philol., lecturer of Chair of Classical Philology, University of Latvia

Brigita Cīrule - classical philologist, Dr. philol., associated professor of Chair of Classical Philology, University of Latvia

Ieva Fībiga - classical philologist, Mag. philol., graduate of University of Latvia

Dens Dimiňš - classical philologist and translator, Mag. philol., Ph.D. student, University of Iceland

Maria Giannaki - doctor of the University of Paris-Sorbonne (France)

Ilona Gorneveva - classical philologist, Mag. philol., lecturer of Chair of Classical Philology, University of Latvia

Igors Koņins - classical philologist, Mag. philol., graduate of University of Latvia

Brigita Kukjalko - classical philologist, Dr. philol., lecturer of Chair of Classical Philology, University of Latvia

Mārtiňš Laizāns - classical philologist, Bac. philol., student of postgraduate studies, University of Latvia

Ojārs Lāms - scholar of literature, classical philologist, Dr. philol., professor of Department of Latvian and Baltic Studies, University of Latvia

Liva Muižniece - philosopher, Dr. phil., researcher at the Institute of Philosophy and Sociology of the University of Latvia, reader at the Department of Classical Philology and Anthropology Studies of the Faculty of Humanities of the University of Latvia and at the Faculty of History and Philosophy of the University of Latvia

Vita Paparinska - classical philologist, Dr. philol., professor of Chair of Classical Philology, University of Latvia

Ilze Rūmniece - classical philologist, Dr. philol., professor of Chair of Classical Philology, University of Latvia

Iveta Skrastina - classical philologist, Mag. philol., graduate of University of Latvia

Dace Strelēvica-Ošiņa - linguist, Dr. philol., researcher of Latvian Language Institute of the University of Latvia

Georgios Theotokis - scholar in military history, Dr. hist., assistant professor of European History, Fatih University (Turkey)

Harijs Tumans - scholar in ancient history, Dr. hist., associated professor of Chair of Archaeology and Auxiliary Disciplines of History 


\section{ANTIQUITAS VIVA IV STUDIA CLASSICA}

Editors Brigita Kukjalko, Ojārs Lāms, Ilze Rūmniece

The University of Latvia Press

Riga 2014

In Latvian and English

ANTIQUITAS VIVA IV

STUDIA CLASSICA

Sast. Brigita Kukjalko, Ojārs Lāms, Ilze Rūmniece, 2014

LU Akadēmiskais apgāds

Baznīcas iela 5, Rīga, LV-1010

Tālrunis 67034535

Iespiests SIA «Latgales druka» 